


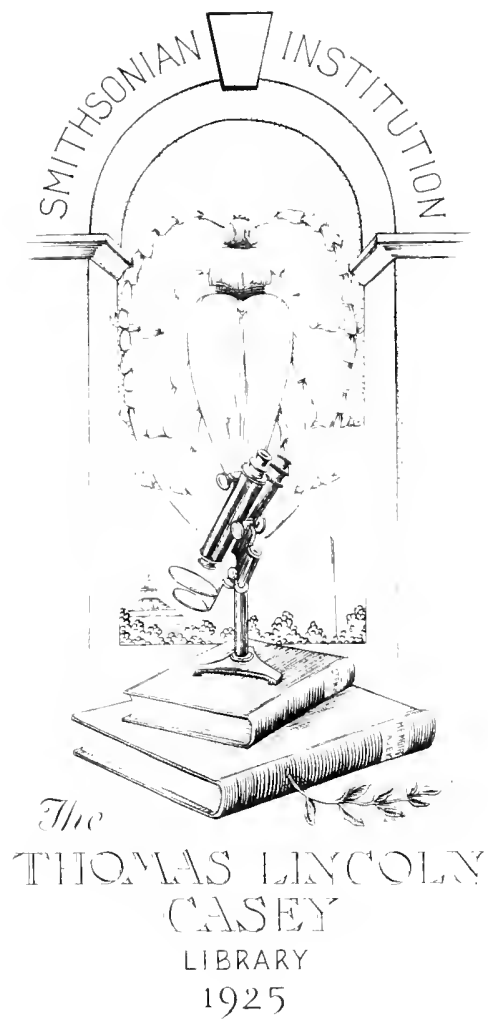







\title{
COLEOPTEROLOGICAL NOTICES.
}

I.

\author{
WITII AN APPENDIX
}

ON THE

TERMITOPHILOUS STAPHYLINIDE OF PANAMA.

BY

THOS. L. CASEY.

[Extract from the Andals of the New York ACADEMy of Sciences, Vol. V.] 

II.-Coleopterological Notices.

I.

BY TIIOMAS L. CASEY.

Read October $7,1559$.

The following pages cmbody the results of a number of detached studies in various parts of the Coleopterous scries, and are confined, in general, to the fanna of America north of Mexico. The fanily P'halacride, and the genera Thinobius, Aploderus, and Limnichus are trated monographically.

I have to acknowlerge my alpureciation of the kindness shown me by the authorities of the Museum of Comparative hoology, at Cambridge, Mass, nurler the ruratorship of Dr. H. A. Hagen, for permission to examine the types of $\mathrm{Dr}$. LeConte, without which no systematic work of scientific value could have been accomplishert.

I am also indebted to I'rof. C. T. Riley for the use of the material of the National Museum, which has heen of great servier in determining geographical distribution in the Phalacridae, and to Dr. D. Sharp, and Messrs. E. A. Schwarz, Otto Lugger, and H. F. Wickham, for valuable specimens.

New Yonk, September 29, 1889.

NoTE.

The introduction of new nanes for parts of an insect, when names alpealy in use will serve just as well, should he avoiled, and, as the term hypum re hat heen employed by me in many descriptions for the intlexed sides of either the fronotum or elytra, by prefixing the proper aljective, it naty lowjecter that rpipleurf would serve the same purpose, and that the new word is therefore munecessary. I have consequently determined to restrict the meaning of hypomern, so as to denote simply the inflexerl sides of the pronotum, reserving the worl epiplenre to denote the inflexed sides of the elytra, and the word hym- 
pleme to desirnate the low ro headed matrin of the epipleura, which, although generally small and sometimes olnsolete, occasionally becomes larger and rather conspicuonsly modified. It is hoped that this will tent to promote conciseness, and that the consednuent reduction of words will warrant the proposed nomenclature.

\section{CARABIDE.}

\section{PSEUNOMORPHA Kirby.}

By referring to the table of species published by Dr. Horn (Trans. Am. Ent. Soe, X, 1, 273), it will be seen that the following form is not closely allied to any hitherto known. It is extremely slender, parallel and convex, and is distinguished by the nine series of elytral punctures being very distiuctly tracealjle.

P. cylindrica n. sp.-Paraltel, very convex, rather more than three times at long as wite, nniformly blackish-piceons above; mnder surface and legs bright rufous; integuments highly polished; margins fimbriate. Head short and broad, feebly convex, nearly four-fifths as wide as the prothorax, very finely, sparsely and mevenly punctate, the punctures in the form of minute strongly emlnossed rings; eyes large, finely faceted; antenna slender, compressed, cylindrical; joints four to eleven very compatly joined, second three-fifths as long as the third, the latter longer than the fourth, five to tem subequal, nearly as long as the third, the eleventh longer. L'rothorax suarcely more than one-third willer than long: sides very feeloly convergent from base to apex and just visibly arcuate; basal angles-viewed laterally-broidly rounded, apical narrowly rounded; lase and apex transversely truncate, the former with a fringe of short pointed closely placed sete; disk transversely, very strongly convex, very narrowly explanate along the sides, marginerl at the silles and apex with a wide elevated bead which is completely obsolete throughout the basal nargin, very minutely, sparsely punctate; punctures rather nuevenly distributed, anulate; median impressed line completely obsolete. Scutellum very minute, transversely triangular. Elytra fully as wille as the base of the prothorax, twice as long as wide, three and two-thirds times as long as the prothorax; sides parallel and straight; together abruptly sulitruncate at apex, the truneation hroally arcuate; disk cylindrically and strongly convex, with nine distinct and almost even series of fine distant subasperate pmetures, the punctures of the second series from the suture much larger and with longer setre, those of the fourth series also more distinct but mnch smaller than those of the second; intervals impunctate. Length $7.0 \mathrm{~mm}$.; wielth (base of prothorax) $2.1 \mathrm{~mm}$.

Texas (El Paso). Mr. G. W. Dunn.

The single specimen is a male, and the sexual eharacters are remarkably distinct. The third and fourth segments of the abdomen have, each, a large transversely-elliptical impression, or more appa- 
rently shallow perforation, which is situated in the middle near the base, and about as wide as the length of the fifth tarsal joint; they are similar in form and position; the bottom is flat and dencely spongiose, and the anterior margin bears a fringe of long closelyplaced subreenmbent sete, which extend over and partially protect the sensitive spongiose area. The long second segment is more densely pubescent than the remainder of the abdomen.

\section{STAPHYLINIDE.}

BLEDIUS Leach.

A partial revision of the North American species of this extensive and interesting genus has been published by Dr. LeConte (Trans. Am. Ent. Soe. YI, p. 217 et seq.), and, although apparently somewhat hastily drawn up, the deseriptions there given will serve in most cases for purposen of identifieation. The species as a rule are much larger in size and more open in their habits than those of Trogrophleus, and it is almost certain that the proportion of known to unknown forms is much greater than in that genus, but in spite of this the number of speeies existing in America north of Mexico will probably be found to be in the neighborhood of one hundred and fifty. While, therefore, the time is not yet ripe for a nseful monograph of our species, it is highly desirable that the large number of species discovered in recent years should be assimilated, and the revision above alluded to forms a convenient guide for the distribution of them with regard to their systematic relationship.

The groups adopted by LeConte rest in several eases upon ehar. acters which have been inaceurately stated, and therefore have not the value which apparently belongs to them. The armatus group, for instance, is quite composite, the coxal fissures being open in some and shorter and elosed in others. When open, howerer, as in strenuus, they are not of the same form as in the annularis group, where they are longer, acutely triangular and gradually more widely open toward the coxa. The antennæe in cribricollis and monstratus, with their three-jointed club, are quite different in structure from those of armatus and strenums.

The definition, also, of the cordatus group by the form of the lasal angles of the prothorax is unfortunate, for the form of these angles raries from the broadly rounded and completely obsolete as 
in basalis, to the distinct and even slightly prominent as exhibited in rordatus. There is an undoubted bond of affiliation between the speecies associated by the author in the group, but it cannot be the form of the basal angles. It would be better to separate them as a group on the longer second antennal joint, which is invariahly longer than the next two combined, and the convex head, with small and extremely feehle antennal prominences, or by the small vinemarginate labrum, with the apical edge finely and strongly reffexed, or even hy the peculiar system of coloration.

'The very decided character separating the mandibularis group is not entirely constant, for in several, if not all the species assigned to it, the acute lateral elge is present near the apex, and in some species not assignable to it, as monticola and dimidiatus, the acute margin becomes obsolete lofore reaching the base, and in the latter is totally ahsent, almost throughout the basal sinuation.

These are matters, however, which nust be reserved for a more complete study, and the new species here bronght to notice are distributer in the groups as limited by LeConte, a list showing their relative positions being given under each heading.

It should be said in conclusion that the tarsi are not three-jointed as stated in the books, but more properly four-jointed. In the species allied to armatus, all four joints are perfectly free and distinct, but the basal joint becomes subanchylosed to the second in several species, notably in the semiferruineus group, and in the ammlaris group the anchylosis is generally complete, the tarsus appearing to be three-jointed; even here, however, the suture can often be plainly seen.

\section{Group 1.-mandibularis.}

To additional species assignahle to this group have heen reported, and it is highly probable that brevidens Lec. will prove to be a -rnonym of mandibularis Er, the specimens before me showing all degrees of derelopment of the mandibular tooth.

The magnitude of the triangular incision of the eighth segment in the males of this genus appears to be variable at will, the segment being composed of two orerlapping parts, the edge of one forming an oblitgue line from one side of the apex to the opposite side of the base. When the two parts are pushed apart laterally, the notch at the apex becomes deeper, and as they are closed together it becones smaller, presering however the same relative form. 


\title{
Group 2.-armatus.
}

The succession of species, of which a very large proportion are described below, may be stated as follows:-

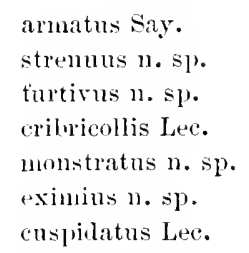

\author{
agonus n. sp. \\ ineptus in. spe. \\ politus Er. \\ Havipennis Lee. \\ lectus n. sp. \\ tenuis n. sp.
}

B. armatus Say.-Oxyt. arm. Say, Journ. Ac. Plila. III, p. 155.-Rather robust and conrex, black; elytra dark rufo-piceous, blackish toward suture and hase; abdomen slightly paler at the apex; legs and antenne dark piceorufous, the latter piceous toward apex; head and prothorax moderately shining, rather coarsely and very strongly reticulato-granulose; abdomen polished, finely reticulate. Hend distinctly narrower than the prothorax, very finluly convex, with a few rery small, feeble and indistinct punctures in the lateral depressions, having, on a line through the nidule of the eyes, two large, approximate, distinct, but not very strongly elevated tubercles, the surface behind them very feetly impressed; epistomal suture tine, impressed, very distinct; antennal prominences very large and strongly elevated ; each apical angle of the epistona with a strong erect process, the apex of which is reflexerl; antenne long and rather slemler; second and third joints equal in length, the latter as long as the fifth and sixth together, outer joints gratually more robust, the tenth scarcely perceptibly wider than long. Pinthorar as wide as the base of the elytra, scarcely more than one-sixth wider than long; sides in apical three-fitths parallel aud nearly straight, then broally rounded to and through the base, the latter less strongly arcuate, the basal and lateral angles entirely olsolete; apical right, rather narrowly but distinctly rounded; apex nearly transrersely truncate; disk sparsely and rery unevenly punctate, the punctures impressed, very distinct but not very coarse; median groove deep, impressed, conspicuons. Elytru qualrate, toward apex scarcely perceptibly wider than the prothorax, about one-fomrth longer than the latter, rather strongly inpressecl near the suture toward base, not rery densely or coarsely pnnetate, the punctures deep and rery distinct, separated ly abont twice their own diameters; pubescence rather sparse, moderate in length, coarse. didomen slightly narrower than the elytra, rather sparsely, finely punctate, the infressed areas inpunctate; under surface finely, more densely punctate, with long coarse conspicuous pubescence. Length $5.5-6.0 \mathrm{~mm}$.

Now Mexico (Albuquerque). Mr. H. F. Wickham.

The above rather full diagnosis is given, as there has been more or less indecision in the identification of this species. The description is taken from the male, the female differing very slightly, the 
tubercles of the front and epistoma being rudimentary. The hypomera are very feebly impressed along the outer margin; they are wide, and the apical width is equal to the length of the sbort, almost completely elosed coxal fissures, and two-thirds as wide as the width at the fissures; the suture is olsolete, lunt traceable from differences in the form of retirnlation. The mentum is distinctly but moderately impressed thronghout the width toward base, the short coriaceons hypoglottis being separated by a fine deep suture.

In the two following species only those characters are mentioned which differ from the corresponding ones of armatus; in other respects they are similar.

B. stremuus u. sp.-Rolust, moderately eonvex, black, the elytra sometines dark piceo-rufons as in amutus. Heal much narrower than the prothorax; "pistomal suture very coarse, deep and distinct; antenne picens-black thronghout, nearly as in comotus. Protherter slightly wider than the lase of the elytra, one-third wider than long; sides in slightly more than apical twothirks nearly straight and rery feelly !nt distinctly divergent from the apex, then strongly convergent, at first nearly straight then broarly ronnler into the lase, without trace of basal angles, the base more feebly arcuate: lateral angles ohtuse hut very narrowly roumled and distinct, apical very slightly obtuse, rather narrowly but distinctly romelerl apex transversely trumcate; punctmes rather more densely and evenly distrihuterl than in armutus. Elytro very slightly wiler than long, at alex scarcely perceptilly wider than the prothorax, the sides slightly divergent and nearly straight, between one-fourth and one-third longer than the prothorax. Aludomen very slightly narrower than the elytra. Length $6.0 \mathrm{~mm}$.

\section{California.}

The description is taken from the male, of which I found a single specimen in the brackish marsh behind the ocean beach at San Francisco. There is an entirely similar specimen from the same locality in the eabinet of Dr. LeConte. With these I have associated a large number of speeimens taken at Los Angeles, which differ only in the sides of the prothorax being parallel and not divergent from the apex as in the San Francisco speeimens-they, however, probalıly represent a variety, as the coxal fissures are distinetly shorter and more nearly elosed. The species differs from armatus in its much more transverse prothorax, rather more robust form, and distinct lateral prothoracie angles.

The hypomera are wide, very feebly inpressed laterally, the apical width loeing slightly more than one-half that at the coxal fissures; the latter are longer than in armatus, being nearly as long as the 
width of the hypomera at their apex, and are distinetly open, the sides however being parallel, and not angulate and more open toward the coxa, as in the ammularis gromp. The sutures are entirely obsolete, and the mentum is nearly as in armatus.

B. furtivus $n$. sp.-General form and sculpture nearly as in armetus, the tuberches of the vertex being smaller and nore alln'uximate, and the epistomal processes sliorter; onter joints of antenne very slightly more transverse. Pinthorex scarcely perceptibly narrower than the base of the elytra, rather strongly transverse, two-fifths wider than long; sides parallel and straight, strongly convergent in hasal third and nearly straight, the hasal angles very obtuse and very broally rounded, but more distinct than in stremus; lateral angles olstuse but very narrowly roumder and distinct, apical right and very broadly rounded, the apex hoadly and very distinctly arenate throughout the width, otherwise nearly as in stremus. Elytra scarcely as long as wide, about twofifths longer and, near the alex, fully one-fourth wider than the prothorax, the sides distinctly divergent. Aldomen entirely impuntate along a broal and distinct merlian line, finely and rather densely punctate beneath. Length $5.0 \mathrm{~mm}$.

Oregon (The Dalles). Mr. H. F. Wickham.

Although the abdominal punctures are sparser along the midule in armatus, there is no well-defined line in which they are cutirely absent, as in furtives; this line is, howerer, hroul and almost entirely free from punctures in strenum.

This species, the description of which is taken from the male, differs greatly from armatus in its much shorter aml more transverse prothorax, with distinet lateral angles, and from stremeus in the broadly rounded apex and apical angles of the same part. The prosternal sutures are more distinct than in either of the preeeding speeics, and hecanse of the greater depression of the apinal angles of the pronotum, the hypomera are, at apex, distinctly less than one-half as wille as at the eoxal fissure; the latter is slightly shorter than the hypomeral width in continuation of it, and is narrowly open, being intermediate between the same part in armatus and strenues. The bypomera are not distinetly impresied externally. The mentum is nearly as in the two preceding species.

The three speeies armatus, strenus and furtivus, althongh closely allied, are almost undoubterly distinct; if however this should prove not to be the ease, the structure of the prosternmm and hyponera must be considered of very little ralue, eren in the separation of species. 
B. monstratus n. sp.- Rather slemfler and convex, parallel, lark testacenus: ablomen chark piceous-hrown; elytra paler, flavate throughout; legs and antemne flavate; head strongly shining, retieulato-granulose, the median tulereles, antemal prominences and apieal part of the epistoma highly polisherl and not reticnlate; pronotmm polished, very fiebly reticnlate near the punetures; abdomen moderately shining, very strongly reticulate. Head very small, mnch narrower and sherter than the prothorax; ryes morerately prominent; on a line through their apical thind there are two very approximate prominent tubercles, behind and between which there is a short feeble canalienlation; between them and the large prominent antennal tubereulations there are a few sinall, rather distinet fonctures: snture short, transverse, feeble, not impressed, situated immediately before the tuberces of the vertex: apieal angles of the epistoma tulerenlate, the tubercles grambally olsolete fosteriorly, aml slightly more approximate than the angles: antemue rather short and slencler, the three last joints abruptly wiler forming a (club); seend distinetly longer than the thire, four to seven moniliform and subglobular, eighth slightly wider, transwersely oval, ninth and tenth strongly transverse, eleventh short, ovoidal, slightly narrower than the tenth, longer than wide. Porthora large, about one-fourtlu wider than long; sides from near the apex to hasal fifth parallel and straiglit, them abuptly, broadly romeded into the base, withont trace of hasal or lateral angles, the hase loroally distinctly arcuate, the ajex transversely truncate: apical angles right and distinctly rounded; disk extremely coarsely punctate, the pmotures very strongly and broally impresised, deep, distant ly rather less than their ww diameters anteriorly, beeoning much fimer and sparse towarl base; melian groove wide, entire, very hroadly and deeply impressed, conspicums. Elytio scarenly as long as the prothorax and very distinetly narrower, scarely as long as wile, very broadly and just visibly inpressert on the suture at the base; siles very feetly divergent; surface vely finely and densely punctate, the fennetures distant by nearly twiee their own dianeters; ponleserence dense, moderate in length. Abdomen just visibly willer from hase to ajex, at which point it is fully as wite as the elytra; sides straight ; surface very finely, feelly, indistinctly and rather sparsely punctate, rather finely, more distinetly and densely so beneath. Leugth $3.8-4.3 \mathrm{~mm}$.

\section{California (San Francisco).}

The type of this interesting and very distinct species is a male, but possesses no decided sexual modification at the apex of the abdomen. It is closely related to cribricollis Lec, but is immediately distinguishahle by its rery large prothorax and small elytra. It should form, together with cribricollis, a group distinet from the armutus group of LeConte, heause of its very short completely closed coxal fissures, and threejointed antennal chub.

The apical angles of the pronotum are abruptly and strongly deflexed, the hypomera wide, very deeply and broadly concave throughout, the coxal fissures extremely short, closed and directerl 
strongly and obliquely forward. The sntures are obsulete. The mentmm is ahmost flat, shining and reticulate. The color occasionally becomes very pale flavate-brown throughout.

B. eximius n. sp.-Rather narrow and depressed, sulprarallel, black; prothorax palle, red-brown; elytra same, slightly elonded with piceous trowarl lase; abdomen paler at apex, black beneath; legs and antenne testaceous, the latter infuscate tomarl apex; head very slightly shining, finely, rather strongly granulose; pronotum distinetly shining, finely and rather strongly grannlato-reticulate; abdomen folished, finely reticulate, more strongly so toward apex. Head distinetly narrower than the prothorax, very feebly conrex, with a few small scattered punctures haterally ; vertex with an elungate feeble impressed forea, on either side of which the surface is very feehly swollen; epistomal sutnre strong, areuate, broadly inpressenl; anterior angles of the epistoma strongly tubereulate; antennal prominences large and very strong, their apices externally finely and strongly margined with an elevated bean; antenne moderate in length, rather strongly, gratualiy incrassate; third joint rather longel than the second and as long as the fourtlo and fifth conbined, tenth fully three-fourths wider than long. Prothorux just visibly narrower than the base of the elytra, one-fourth wider than long; sides in rather more than apical two-thirds parallet and straight, then convergent and straight for a short distance, then broally romded into the lase without trace of basal angles; base transverse; apex just visilbly arcuate: apical angles right and extremely narrowly rounded, lateral rery obtuse, lroally rounded and not distinet; disk rather coarsely, slarsely and very unevenly punetate; median groove wide, very deeply impressed, entire and conspicunts. Elytrit fully as long as wile, one-fifth wider and one-half longer than the prothorax; sides nearly straight, slightly divergent; surface very feebly inuresserl on each side of the suture at base, rather coarsely, mokerately densely and denely punctate, the punctures gentrally separated ly nearly twice their own wilths; pubescence rather long, distinct but not very dense. Abromen at apex marly as wide as the elytra, at base much narrower: sides straight and distinctly divergent; surface finely, rather sparsely punctate, finely and densely so beneath, with the surface finely granulato-rugulose and somewhat dull. Lengtlı $5.5 \mathrm{~mm}$.

\section{California (San Diego).}

The hypomera are flat, but strongly depressed below the lateral edges, the latter being very prominent and acute thronghout; at apex the width is fully three-fourths that at the fissures, which are but slightly shorter than the adjacent hypomeral width, and narrowly but very distinetly open; the prosternal sutures are alnost completely obliterated but rather distinctly traceable. The mentum is shining, coarsely and very strongly reticulate, and broally im- 
pressed throughont the width, the terminal membranous hypoglottis almost one-third as long.

The description of this very distinct species is taken from the male, the eighth ventral segment heing very deeply incised, the seventh broadly eusped. It should be placed near cuspidatus.

B. agonus n. sp.-Skemler, molerately depressed; sides parallel; piceons, wytra rufo-testacems. broally and imlefinitely rlouded with darker eastaneons toward the suture and hatse; ahiomen hlack; legs throughout and coxe jale flavate; antemie brownish-rufous. Heol very slightly narrower than the prothorax, fexhly shining, densely, coarsely granulato-reticulate, not distinctly punctate; eyes rather lare and prominent, the setie very short and sparse: antemal fuminences strong, the ejistmal suture slightly impressed; rertex not tuberendate. hut having a large rommet bather deeply-impressed puncture: antennit molemate, second joint one-third longer and more robust than the third. four to six much shorter, sulmoniliform, six to eight rapidly wider; outer joints strmgly transverse, eleventh ovoldal, searcely as long as the two preceding trogether. Prothorm as wide ats the hase of the ely tra, about me-third wiler than long: siles in anterior two-thirls parallel and ahmost straight, then convergent and arcuate to the base which is transverse; basal angles very ohtuse and rommlet, lateral rounder and entirely obliterated, apical right and narrowly romuled; aluex transverse; disk teebly shining, densely, coarsely gramulato-retienlate, rather finely lout distinctly, very sparsely and some what merenly punctate, the pubescence very sparse hut rather fong: merlian groove very fine and teebly impressed. Elytro very slightly knger than wille, abont two-thirds longer than the prothorax, very finely, feeldy and sparsely punctate, the punctures separated by alout three times their own diameters, but much closer than those of the fronotum; sifles nearly parallel; pulvescence rery sparse am showt. Abdomen as wide as the prothorax, shining, rather finely, densely and strongly reticnlate throughont. finely and very sparsely punctate, the under surface nore densely so and distinctly reticulato-rugulose. Length $4.5 \mathrm{~mm}$.

Etab.

The mentum is broadly and deeply impressed especially toward bare, and the anterior angles of the epistoma are distinetly tuberculate in the male.

1 very distinct species which should be associated with cuspidatus.

B. ineptus 11. sp.-Rather slender ani convex, piceons; elytra pale flavate, the suture narrowly dusky, more broadly so toward base; legs and antenne flavate, the latter infuscate toward ajex; head finely, strongly grannlatoretienlate, feelly shining: pronotum feebly reticulate throughout, except along the merlian line where the surface is polished and the reticulation obsolete, rather strongly shining; alkomen polished but distinctly, evenly reticu- 


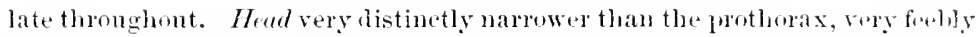
convex, with a few fine seattered and indistinct punctures; median forwal suall, the surface befere it slightly tumid; suture transverse, rather loratily inpresser, distinet; antemal tuberculations rather small, widely distant, rather stromly elerated; antemo molerate, gradually, rather festhy incrasiate; secoml joint more rolust and very much longer than the thiml, ninth and tenth nut nuch longer than the eighth, distinctly wider than long. Prothom seares ly perefetibly narrower than the hase of the elytra, one-fourth wither than long; sicles except in losal fometh and apical sixth, parallel and straight, strougly comvergent and feelly arenate to the hasal angles, which are very whose and hoally romdef, although slightly definable; lateral angles loroally rommled and not very distinct, apreal right, hroally and distinctly lommled; apex transversely truncate; lase just visilly arcuate; disk ratler abruptly and very strongly convex near the apieal, lasal and lateral margins, finely, feehy, very sparsely and somewhat mevenly pmetate, the meilian line rather looally impunctate, the median groove abmost completely of solete, only imlerfectly visible moler certain angles of illumination. Elytien very slightly willer and ahont two-fifths longer than the frothorax, fully as long as wirk ; siras nearly straight, scarcely visibly divergent; disk very fowly impressent near the suture towarl hase, somewlat finely and sparsely but distinctly punctate, the punctures separated ly rather more than twice their own hiameters; mbescence very sparse, moterats in length. Alshmen parallel, slightly narmower than the elytra, very tinely am sparsely pmetate, leneath morecoarcely mevenly and rather sparsely punctate. Length 4.2-4.7 mu.

New Mexico (Albnquerque), Mr. Wrickham; Texas (El Paso), Mr. Dunn.

The hypomera are wide, rather flat but very feehly impressed near the lateral edges, the coxal fissures short, about two-thirds as long as the adjacent hypomeral width and narrowly but distinetly open; the prosternal sutures are almost completely olisolete. The mentum in flat, scarcely pereeptibly and indefinitely concave, coarsely but very feebly reticulate, polished, the terminal membranous hyoglotti-trongly developed, nearly one-third as long as the ebitinous portion. The anterior angles of the epistoma are finely and rery strongly tuberculate in the male.

This species should be placed near politus. It is rather closely allied to ayomes, but differs in its distinctly narrower hear, more broally rounded apical angles of the prothorax, the latter heing distinctly less transverse, and in its shorter, more coarsely decply and dencely punctate elytra.

B. lectus n. sp.-Rather slender, sulpiarallel, black; promotmm prater, piceo-rnfous; elytra lright rutous, very broblly clondet with ficeons-blark toward suture and hase: legs and anteme pale testaceols, the latter sliglitly

Axpals N. Y. Acap. Scl., Dec. 1889.-4 
infinscate; head rather finely and strongly, pronotum more coarsely and feelly reticulate, the latter rather strongly shining; abdomen polished, rather coarsely wenly and feebly reticnlate. Ileod slightly narrower than the prothorax, feethy convex: eyes rather large, moderately and erenly convex; median puncture very small and feelole; vertex not tuberenlate; antennal promiuences rather latge and strong ; suture distinct; apical angles of the epistona slightly tumicl; antenne rather long and slender, gradually and moderately incrassate; secoml joint more rolust and distinctly longer than the third, fitth lenger than wirle, tentl very slightly wirler than long, the eleventh one-half longer than wide, rather acutely and grahlually pointed. Prothorex scarcely perceptiluy narrower than the base of the elytra, just visilly willer than long; sides extept in basal fourth garallel and nearly straight, then convergent and perfeetly straight to the hasal angles, which are sery olotuse lont rather narrewly rommed and definable although not distinct; lateral angles obtuse. narmwly roumled and distinct, apical nearly right, very narrowly rounder : apex lroadly and very distinctly arenate: lase rery feelly so; disk rather convex, very finely and sparsely punctate, the punctures very feebly inl pesom although distinct, very nuevenly distributed; median groove very fine, feebly impressed, entire; pubescence very easily abraded and inconspicnons. Elytru as long as wide, one-fourth willer and scarcely more than one-third longer than the prothorax; sides distinetly divergent and feelly arcuate, distinctly so towarl apes: surface feebly inpressed near the suture almost throughont the length, somewhat deeply and densely punctate, the punctures rather larger ami much more distinet than those of the pronotum, selarated by slightly more than their own dianeters; pubescence short, fine, sparse and ineonspicunus. Ademen parallel, distinctly narrower than the elytra, finely, sparsely punctate, finely and ilensely so beneath. Length $4.2 \mathrm{~mm}$.

\section{Califormia (Sonoma Co.).}

The hyponera are narrowly and strongly impressed along the outer edge, the width at the apex being fully two-thirds as great as at the fissures; the latter are very short, scarcely two-thirds as long as the adjacent hyponeral width, and are distinctly and rather witlely open; the prosternal sutures are almost completely obsolete, although traceable. The mentum is shining, coarsely and strongly reticulate and very feebly coneave, the bypoglottis very short.

Belongs neal flaripennis Lec, from which it is at once distinguishable by its narrower forn, less distinct prosternal impressions in front of the coxal fissures, less widely open fissures, different coloration and very different sexulal characters. It is descrilsed from the male, the eighth segment of the abdomen heing deeply and narrowly incised.

H. tenuis u. sp.-Blender, black; pronotnm hrown ; elytra paler, brownish-flarate, very feebly clonded toward the suture near the base; legs through- 
out and coxe pale flavate; antemne brownish-testaceons, paler towarl hase; head and pronotum moderately shining, densely and strongly granulose and graunlato-reticulate respectively ; abdomen polished, reticulate. Herd alumst as wile as the prothorax; eyes moderate, sete very slort; antennal proninences very strong; suture feebly impressed ; surface very sparsely and not listinetly punctate, vertex not tuberculate, having a somewhat elongate inpressed median fovea; antenna rather slender and elongate; second joint longer and slightly more robust than the third, four to six sulvequal and sul,moniliform, six to nine very grathally more rolowt and transverse, nine and ten equal, alont one-third wider than long, eleventh ovoidal, distinetly shorter than the two precenling together. Prothorax slightly narrower than the hase of the elytra, one-fourth wiler than long; sirles in anterior two-thirds parallel and straight, then strongly areuate and moderately convergent to the basal angles, which are obtust, not rounded, and minutely prominent; lateral angles entirely olsolete, broally rounded, apieal right, very narrowly rounded; hase and apex just visibly arcnate; disk somewhat coarsely feebly very sparsely ancl sommliat umevenly punctate, the pubescence rather fong am stout; median groove extremely fine and feelbly impressed. Elytra slightly shorter than whle, akout one-latf longer than the prothorax, and, toward apex, nearly me-third wider: sides slightly divergent, broarly fisthy arenate, very feelly emarginate at alex, the inner angles slightly rounderl ; lisk impressed on the suture behind the sentellom, somewhat coarsely but feelly and sparsely punetate, the punctures distant ly from two to three times their own rlianters, 'liser and smaller than those of the pronotum; pulescence fine, spare and noderate in length. Aldmen unch narrower than the elytra, slightly wiles. than the prothoras, finely, very sparsely punctate, moch more densely so and densely pubescent heneath toward the sides. Length $4.5 \mathrm{~mm}$.

Nevara.

The bypomera are distinctly narrowly impressed near the margin, and are rather wider than the distance thence to the coxe, the roxal fissures heing narrowly open and short. The mentum is broally feebly intresced. The anterior angles of the epistoma, at least in the male, are finely and feebly tubereulate. It is closely allied to lectus, but differs in its more slender form and smaller mole trans:verse prothorax.

The prosternal sutures are obliterated and the mentum is margined at apex with a very thick convex beal-hypoglottis_- -eparated by a finc deep groove. 


\section{Group 3.-semiferrugineus.}

But few new species are to be assigned to this group, as may be seen from the following complete list:-

\author{
turgielus n. sp. \\ semiferrugineus Lee. \\ rotumbicollis Lete \\ funatus Lece. \\ foraminosus $11.81 \%$ \\ nitidivejs Lete
}

\author{
opracifrons Lee. \\ rubiginusus Er. \\ gravidus $11.81 \%$ \\ analis lee. \\ nitidiecollis Lere \\ assimilis n. s1.
}

B. turgidus n. sp.--Tather rolust, parallel, somewhat convex, black; Hytral lright rufons, the base piceous-black, the same color extemling along the sutne, very narrowly so toward apex; legs and antemne testaceons, the latter infuseate toward apex; head and promotum rather strongly shining, hut densely and rather strongly gramulato-reticulate; ablomen polished, tinety, feelly retienlate throughout. Head mueh narrower than the prothorax, not very convex; eyes rather small; surface with a few widely scattered, moderately distinet functures; basal transverse line very strongly impressed, the median forea small but distinct, being an angular break in the contimuity of the grvove: tubereulations wanting; antemal prominences rather strong: suture fine lint distinct; antenne rather slemder, gradually and moderately inerasiate from the sixtl joint, molerately compressenl ; onter joints slightly transierse, secomd distinetly shorter than the next two together. Prothorar sliphtly willer than the base of the elytra, one-third wider than long; sides in anterior three-fourths parallel and very feebly arcuate, then convergent and very feebly areuate, distinctly simate for a short distance before the lasal angles, whiel are sliglitly ohtuse, not distinctly romded and somewhat prominent; lateral angles lowally romder, not very distinet, apical slightly obtuse and narrowly soumled ; apex fully two-tifths wider than the hase, both transrersely trumcate: disk somewhat earsely, very sparsely and distinetly punctate, the punctures unevenly distributed ami deeply impressed; pulestence very short, sparse and inconspicuous; metian groove very fine, feebly imlnesserl, olsolete in apical two-tifths. Elytir distinetly wider than long, scarcely one-fourth longer than the prothorax, and, at apex, not visibly wider: willes rather strungly divergent, feebly areuate: arex rather strongly, conjointly enumpinate in the mithle: surface with a small elongate impression on eath side of the suture at the base, not very coarsely, somewhat sparsely and unerenly functate; punetures rather deep and distinct, inpmesed, separated ly from two to three tines their own dianeters; pubescence merlerate in length, tine, rather sparse. Aldomen mearly as wide as dhe dytra, finely, very sparsely pmetate, finely, rather sparsely so beneath. Length 4.5 mm.

Colorado (Ft. Garland). Mr. E. A. Schwarz.

The hypomera are wide, about as wide as the length of the coxal 
fissures; they are nearly flat anteriorly but strongly impressed near the lateral edere posteriorly, the sutures distinct, the fissures: moderate in leugth and not entirely elosed, the posterior edge below the anterior appearing elosed when viewed vertically, but wirlely open near the coxa. The mentum is moderate, shining, coarsely reticulate and nearly flat.

This very distinct and beautiful species belongs. because of its distinet sutures and half-chosed coxal fissures, in the stmifermit ne'us group of LeConte, but differs from every deseribed species in its prominent basal angles of the prothorax.

B. foraminosus n. $\mathrm{sp}_{\mathrm{p}}$-Rather robust and convex, black; elytra rufous, clomeled with piceous-black toward base; legs and antenure diark testaceous, the latter blackish towad apex; head finely reticulato-tranulowe, morlerately shining; promotmon polished, not reticulate; alndonen polished, finely teebly retienlate. Hed slightly narower than the prothorax, slightly convex; eyes rather small : snrface distinctly and rather densely punctate; median forea deep, distinct and slightly elongate, the sulface immediately alout it polisher and inpmetate; suture fine, fenbly areuate, listinet but not impressed; antemnal prominences rather large but short and not very strongly elerated; antenne rather robust and compact, moderate in length, very erenly aurd distinctly incrassate; seemr joint but slightly longer than the third, sixth distinctly wider than long, six to eight suberpal in length, increasing in wilth, nine and ten abruptly nuch longer but not wider, the latter rather longer than wide, eleventh long, gratually pointed. Prothorex slightly narower than the base of the elytra, one-finurth willer than long; sides in apieal three-fitths parallel and straight, then converent and just visibly arcuate, and then hroally rounder into the hase, the basal angles being very obtuse, broarly rounded and not di-tinct; lateral angles very obtuse but rather narrowly rounded and quite distinct, apical richt and distinctly rounderl; apex loradly, very teebly arcuate, the base very distinctly arcuate; disk rather coarsely, very deeply and elensely punctate, the punctures almost contignous laterally hut a little more disperserl toward the median groove, which is very coarse, deep and conspicuous. Elytre scarcely as long as wide, one-fitth wider and one-third longer than the prothorax, not very coarsely but very deeply and rather densely punctate, the punctures separated by slightly more than their own widths; pubescence noderate in length, not very dense. Aldomen parallel, almost as wide as the elytra, feebly, finely and not very densely functate, beneath polished and more densely punctate. Length $5.5 \mathrm{~mm}$.

California (Lake Co.). Mr. Fuchs.

This species is allied to fumatus Lec., but differs greatly in its smaller eyes, straight and not broadly rounded sides of the prothorax, deeper and more distinct punctuation of the head, and, especially, in the structure of the antenne which in fumatus are 
more slender, and much more feebly incrassate, with joints six and soven distinctly longer than wide, and eight fully as long as wide, nine and ten innch less abruptly longer than eight; in the present species the eighth joint is nearly one-half wider than loug. The description is taken from the only specimen which I have seen, and this is unfortumately the female, but the above comprarison has been malle with the same sex of fumatus.

The hypomera are flat, rather wide, the aprical width fully onehalf that at the fissures, the latter rather long but slightly shorter than the hypomeral wilth in continuation of them, and are almost completely alosed; the prosternal sutures are rery distinct, being defined by a fine elerated line. The mentum is shining, coarsely reticulate, fincly, deeply impressed along the base and unusually coaricely, deeply but rery sparsely punctate.

I. gravidus n. sp.-Moderately robnst, rather convex, picens: elytra might rufons, feebly clonded with piceons toward base, and shightly along the suture; aldomen above and beneath dark rufo-testaceons, the apices of the seguents clonded with freeons; hear finely reticnlate, feelly shining: pronotum distinetly reticulate, rather strongly shining, the reticulation obsolete posteriorly toward the sides, the surface becoming polished; aldomen polished, finely, very feebly and subelsoletely reticulate. Heal rather distinctly narrower than the prothorix, feelly anrex, finely, sparsely and not rery distinctly punctate, not tmmid in the midhle, the menlian puncture small, romnded, feelly impressed, not surrounded by a polished area ; antennal tuberculations large, short, moderately prominent, polished toward apex : sutnre time, feebly areuate, not inplressed; apical angles of the epistoma distinctly tuberculate; eyes large, more convex behind; antenne rather long, the last five joints gralnally, evenly and molerately incrassate : second joint scarcely perceptibly Ionger, althongh distinctly more robust than the third, sixth slightly wider than longe, eighth alout one-thirel wider than long, nintle and tenth longer, the latter slightly wider than long, elerenth one-half longer than wide. Prothorux rather distinctly narrower than the base of the elytra, nearly one-third wider than long; sides from apical fouth to just belind the mildle parallel and straight, then convergent and just risibly arcuate to the basal angles, which are very ol,tuse, rather hoadly monded although somewhat definable: lateral

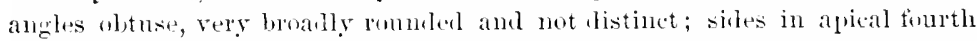
convergent and strongly areuate, the angles at the apex heing slightly obtuse and searcely at all roumber a a arenate; disk convex, fincly, sparsely and mevenly punctate, the punctures distinct but not very deep, the median groove rather fine but deeply innpessed and distinet. Elytro not 'pute as long as wide, together lroadly, angularly emarginate at apex, one-fourth wider and one-third longer than the protherax; siles feebly divergent; lisk tlattened lut not distinetly inpressed on the 
sutme at the base, rather timely but distinctly ame demsely punctite. the pmotures separated by but very slightly more than their own dianeters: fubeseence moderate in length. Alulomen parallel, distinctly narrower than the elytra, rather finely but not very densely punctate towark the apines of the segments, polished and morerately densely punctate leneath. Lemgth $5.0-5.7 \mathrm{~mm}$.

New Mexico (Albuquerque). Mr. H. F. Wicliham; Utah.

The hypomera are broally, very feebly impressed along the onter edge, the apex about three-fifths as wide as the width at the fissures, the latter rather long, fully as long as the arljacent hypomeral wirlth, and almost completely closed, the prosternal sutures distinct. The mentum is not visibly punctate, shining, coarsely reticulate and distinctly impressed along the base.

The description of this distinct species is taken from the male, the sixth segment being evenly emarginate in circular are, the emargination simple, not maroined with memlorane, and ahout five times as wide as deep; the surface at the sides of the emargination lears sereral very long, erect, interlacing sete. It should be placed near rubiginosus Er.

The punctures of the pronotum vary in size, and in some sprecimens are slightly coarser.

B. assimilis n. sp. (Fauvel MS.).-Rather slenter am enrex, bark: elytra piceous; legs and antemne pale flavate, the latter infuscate except toward base; head and prothorax finely, tensely gramulate, feebly shining;

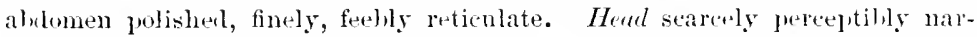
rower than the frothorax, rather enrex, finely, very obsoletely ponctate, not tuberenlate; median fova snitl, feebly impressed; antemnal prominenes small, feeble; suture fine, distinet, not inpressed, areuate; epistoma sinn]le; antennæe rather long, morkerately and gradually incrassate; secom joint tistinctly longer than the third, four to six decreasing in length, the latter distinctly wirler than long, seventh longel, slightly wider than long, eight to ten increasing in length, the latter longer than wile, eleventh nearly twice as long as wille, shorter than the two precerling together; last three joints togethrer as: long as the preceding six. Protherex slighlitly but distinctly narrower than the base of the elytra, about one-fimrth willer than long; sicles in anterior twothirds parallel and stright, then convergent and nealy straimht to the hasal angles, which are obtuse, narrowly rounded, rather listinet but not at all prominent; lateral angles obtuse, narrowly roumbed aud ratletr distinet, al ical jight and distinctly romoled; apex almost transversely trumcate; disk rery densely and somewhat deeply punctate, the punctures moderate in size, separated by searcely their ow n lianeters but slightly sparser toward the median impnetate line, which is entire and molerate in width, the molian groms being completely obsolete. Elytro nearly as long as wille, two-fifthis longer, 
and rather more than one-third wider than the prothorax, fetlly impressed near the suture toward base, rather finely penctate, the punctures distinct, rather smaller than those of the prothorax, and separated by nearly twice their own diannters. Alutumen slightly narower than the elytra, gradually wider from lase to apex, fincly, somewhat densely punctate, beneath polished, finely, somewhat densely punctate. Length 3.3 mm.

Illinois; Iowa.

The description is taken from the male, and the sexual characters at the apex of the ablomen are, as nsual in the semifermugnens groul, very strongly marked, in this case more remarkable than in any other species which I have seen, and reminding us somewhat of the male modification in Apocellus.

The sixth segment is broatly, strongly emarginate in eirenlar are nearly throughout the wilth, the emargination horelered with a witle and thin, rery slightly inflexed membrane; at each sicle of the emargination there is a small, aente, pointer tooth; the seventh segment is slightly producerl and romeled in the midtle, the eighth as usual olliquely dirided, the two orrlapping portions having an acute apical incisure, which can apparently be varied at will.

The hypomera are wide, flat, the suture clistinct; the eoxal fissures very short, almost completely closed; the mentum shining, retienlate, very fechly, transwersely implessed near the base. The species should be placed immediately after nitidicollis Lee.

\section{Group 4.-anmularis.}

This group is by far the most extensive of the genus; the species may be provisionally arranged in the following order:-

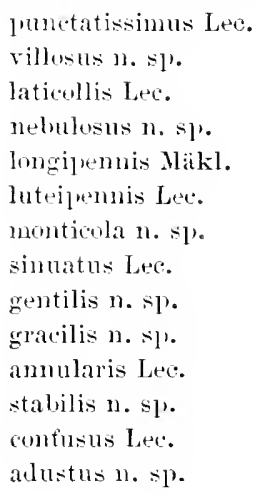

ruficornis Lee.

languidus n. sp.

licolor n. spe

divisus Lec.

pletralis Lec.

diagomalis Lee.

parricollis $11 . \mathrm{sp}$.

tau Lec.

ornatus Lee.

suturalis Lee.

pliytosimns Lec.

cogmatus Lee.

emarginatus Say. troglodytes Er.

honestus n. sp. 


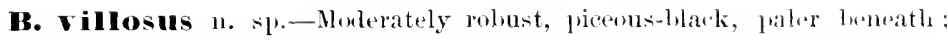
clytra pale brownish, the sutule and base slightly and infefinitely darker: legs and antenne pale flavo-testaceous, the latter infuseate; heal and pomotum strongly shining, finely and very teebly reticulate; abdomen julistoel, very minutely, feebly reticulate, the basal impressions very much more andraly and strongly so. Head distinetly narrower than the prothorax, not distinctly comvex, with a few scattered, well-defined punetures, not tuleserulate; bisal transverse groove broally inplessed, strong; median forea rather barlly defined; antemal toherevlations small but distinct; sotme fime and fechle, almost completely obliterated in the midule; antemus rather long, gradually and moderately inerassate; ontex joints slightly transverse; secomd modn shorter than the next two together, fourth and fith longer than wile. I Pothora distinctly narower than the hass of the elytra, one-timuth wider than long ; sides in anterior three-fifths just visibly diverent from the a pex, and rory teebly

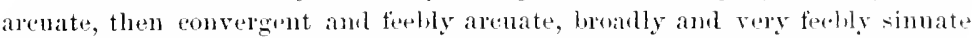
before the basal angles, which are very ohtuse, romeled and not at all fromiment althougle definable; lateral angles broally romeled, not very instinet, apieal ohtuse, distinetly rommed; apex nearly two-fith wisler than the base, both broully, feebly arenate; lisk very feetely comvex, ratlere finely, densely punctate, the punctures deep and well detined, sparser near the apex and median groove, the latter very deel, whlely impressed amd comsigenous through-

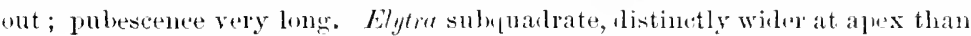
at hase, one-thind wider and one-half longer than the prothorax; sides feebly

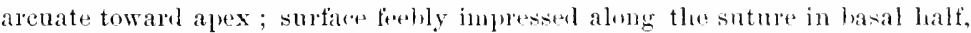
cuarsely, very deeply and domely punctate; punctures separated by tion less

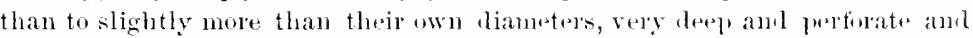
distinetly larger than those of the pronotum: pulescence very bolle, rather dense, cineleo-flavate aml conspigenous. Alulemen slightly narrower than thr clytra, rather coarsely and dinsely lunetate upon the convex portinns, the hasal impressions impunctate, bencath densely punctate, the lubercente very long. Length $5.0 \mathrm{~mm}$.

\section{California.}

A very well-marked species in its extremely long conspicuous pubescence, almost twice as long as in any other known to me. 'The hypomera are about one-half as wirle as the distance thence to the coxe, nearly flat anteriorly, strongly impressed along the midrle, the sutures almost completely eflaced, the coxal fissures rery long and widely open. The mentum is very deeply impresised in the middle toward base, almost exarated, highly polished and quite devoid of reticulation, except near the lateral edges and sometimes near the apex.

For the present villosus may be associated with laticollis.

B. nebulosus n. ip.-Rather rohust, nearly parallel, blark; elytra pale rufo-ferruginous, indefinitely clouded with piceous-black teward the suture, 
rspecially towarl the base; abdomen piceous-lilack, rufo-piceous beneath: metastrenum lolack; legs and antemme pale testaceous, the latter infuscate toward ajex; head and pronotum feebly shining, rather coarsely and strongly granulato-roticulate; aldomen fincly, evenly and feelly reticulate throughout. jolishel. Heal slightly narrower than the prothorax; eyes large; surface ratler depressed, finely, very sparsely and indistinctly junctate, not tulerculate; melian forea romiled, distinct; transverse impresserl line distinct; antemual tuberenlations small. tieble; suture fine, fechly defined; antenna rather stronely incrassate; second joint more rohust and nearly as long as the next two, five to seren increasing grarually in willh, eight to ten wider, twothimes wider than bomg, eleventh not as long as the two preceding combined. Protherer just visibly narower than the base of the elytra, nearly one-halt wiler than long; sicles in anterior two-thirds parallel and lonally lout distinctly arcuate, then convergent and straight to the basal angles, which are ohtuse, slgghtly rounded, rather distinct but not at all pominent; lateral angles broally romded, not distinet, apical slightly olutuse and very narrowly romuded; apex truncate, less than one-third wider than the biste, which is lond and festly arcuate: ask ratler finely and sparsely pumetate, the punctures leel and distinctly defined, shightly closer toward hase; pulescence nowerate in length, slarse, jale tlavate; median groove rather fine but very detely impressed and conspicuous. Elytre nearly as long as wicle, onte-halt longer and nearly one-fourth wirler than the prothorax ; sides straight, slightly dirergent; surface distinctly impressed near tle suture at base, donsely, rather finely punctate, the punctures very deep and distinct and separated by slightly nore than their own diameters; pubesence fine, nomberate in length. Aludomen nearly as wide as the elytra, very finely, sparsely punctate; muder surface finely and ratleer sparsely so. Length $3.9 \mathrm{~nm}$.

Iowa.

The hypomera are moderate in width, deeply concare throughout, the lateral elges being very prominent; sutures distinct; coxal fissures morlerate in length, widely open. The mentum is large and extremely frebly coneave throughont its extent; it is rather shining and coarsely reticulate, the membranous hypoglotis rery short, inflexed and inconspicuous.

Belongs neall laticollis, but is well distinguished by its more shining head and pronotum, the punctures of the latter heing better defined and the basal angles rather more distinct, by its relatirely larger and more finely punctate elytra, lesi concare mentum, much wider pronotal hypomera, shorter coxal fissures, and larger but less prominent eyes.

B. monticola $n$. sp,-Rather slender, hack; elytra and antemne piceons-blakk, the latter very slightly paler toward base; legs rnfous; hear and prothorax dull, densely granulose; elytra and abelomen polished, the latter 
reticulate, much more strongly so toward base. Hroul very nearly as wile as the prothorax; eyes rather small, very prominent; antennal prominemes: rather large, moderately conspienous ; sutnre fine but distinst; surface behind the snture dull and densely granulate, finely, rather densely lout rery inlistinctly punctate; vertex neither tuberculate nor foreate, rather convex: "pistoma shining, coarsely reticulate: antenne ratler robust ; seconl joint nearly as long as the next two, third lont shightly shorter than the fonrth and tifth together, four to six short, the latter transverse, seven to ten rather abruptly wider and gratually longer, the tenth nearly two-thirds wider than long, eleventh short, much shorter than the two precelling combined. Protlorar lis. tinctly narrower than the base of the elytra, scarcely one-fifth wilter than long; sides in anterior two-thirds parallel and very slightly archate, then convergent and feebly sinnate to the hasal angles, which are oltuse and very namrorly rommled, not at all proninent, the acnte lateral enge entirely disaphearing just lefore attaining them ; lateral angles very obtuse and rounded lont sonewhat distinct, apical distinctly rounded; apex alont one-third wiler than the lase, both truncate; disk rather convex, very densely but somewhat imlistinctly punctate, densely but not distinctly pubescent, the merlian groove rather fine but deep and distinct. Elytre chatrate, scarcely one-fourth wider and two-fifths longer than the prothorax, rather convex, hoally inneresed toward lrase near the suture; sirles parallel ; disk rather coarsely, very lopsely and deeply punctate, the punctures separated by scarcely more than one-half their own dianeters, the intervals polished althongh feebly roguluse: polnescence moderate in length, rather coarse and dense, flavo-cinereons and (omspicuons. Ahtomen very slightly narower than the elytra, finely, sparselypunctate, rather coarsely and densely so beneath. Length $2.8 \mathrm{~mm}$.

California (Lake Tahoe, 6200 feet).

A small species, quite distinct in its rery dense punctuation; the absence of an acute lateral marein near the basal angles of the prothorax will distinguish it from its nearest allies; it should be placed near simuatus Lec.

The hypomera are rery broadly, feebly concave and rather more than one-half as wide as the distance thence to coxe, the sutules distinct, the coxal fissures moderate in length and widely open. The mentum is shining, coarsely reticulate and broadly, rather strongly impressed in the midule throughout its length, the coriaceous hypoglottis very short and not distinet.

B. gentilis n. sp.-Dather slender and convex, llack throughout; lens ruto-testaceous; antenne liack, the two hasal and eleventh joints paler, picentestaceons; head and pronotum feebly shining, the former finely granuline. transversely reticnlate near the base, the latter nore coarsely grannlatr-leticulate and shining; elytra and ablonen polished, the latter coarsely reticulate thronghout, the lines very fine. Head very slightly narrower thin the form- 
thurax, rather strongly convex, completely devoid of forea or tulereulations; antenmal frominences small and teeble: epistomal suture fine, feeple, not imfresed: eyes molerate; antenne rather short and strongly incrassate, comlressed; second joint nearly as long as the next two, three to six grarlually -honter, the latter slightly transverse, seven to ten gradually wider, strongly transterse, tenth on the conpressed side nearly twice as wide as long, the elermth ovoidal, olutusely pointed, longer than wide and as long as the prewoling two. Prothorex distinctly narrower than the hase of the elytra. silles in a jieal three-fiftlis jarallel and rather distinetly arcuate, convergent and evenly, very feebly sinuate thence to the lasal angles, which are obtuse, narrowly roumded and not at all pominent; lateral angles very lnoadly olotuse, romded l,ut rather distinct, apinal nearly right, narrowly rom lalf willer than the hase, both subtruncate: disk searcely one-fourth willer than long, rather finely, somewhat densely and distinctly punctate; pulesrence rather long. pale fulvous; median groove rather dedply impresser and very distinct. Elytre quadrate, two-fifths wider and nearly one-half longer than the prothorax; sites nearly straight and aluost parallel: surface densely and somewhat coarsely punctate, the punctures rather deeply impresserl, separated hy alent their own dianeters; pubescence fine, mederate in length, cinereous, rather dense and distinct. Alufomen slightly narrower than the elytra and much wiler than the prothorax, tinely, sparsely punctate, finely and more Iensely so lwneath. Length $3.0 \mathrm{~mm}$.

\section{California (Somoma Co.).}

The mique example represents a very distinct species differing from any other which I have seen; it may, however, be placed next after simuatus in the catalogue.

The hypomera are very narrow, searcely more than one-third as wide as the distance thence to the coxe, very feebly concave, the sutures distinet; the coxal fissures are long and rery widely open. The mentum has a laree, moderately deep median impression ; it is shining and coarsely reticulate, the hypolottis thin, polished, flat, not reticulate and rather long, being about one-fifth as long as the entire mentum, the dividiug suture very feeble.

B. gracilis n. sp. - Slender and somewhat convex, hlack throughout; antenne piceons, paler toward base and apex ; legs testaceous: heal feehly shining, rather coarsely, feelly granulose; pronotum strongly shining, coarsely. strongly reticulate; "lytra and abdonen pwlished, the latter coarsely reticulate, the lines fine. Hemd rather tistinctly narrower than the prothorax, rather strongly convex, not tuberculate; menlian fovea nearly obsolets; surface finely, frarsely and not elistinctly punctate; neck transversely leticulate; antemal tulopreulations small, not strong, polished at the apices; sutule very feeble, not inpressed; antemne molerate, strongly incrassate; second joint much longer thin the next two together, gralually, strongly incrassate from the fourth joint, tenth strongly transverse, eleventh shorter than the two preced- 
ing together. Prothurue alwat one-fifth wider than long, scareely narrowet than the hase of the elytra; sides in anterior two-thinds parallel and tieelyy arenate, then convergent and feehly sinuate to the hasal angles, which are obtuse, extrenely narowly rounded but not proninent; lateral angles very oltuse lut narrowly rounded and rather distinct when viewed sublaterally. less distinct vertically, apical nearly right, slightly but distinctly roumled: apex two-tifths wider than the base, hoth subtrmucate; disk rather strongly consex, ratleer finely but deeply, distinctly and not very densely punctate; pulnescence sparse, moderate in length; median groove very wille, deeply excavated and extremely conspicuous. Elytro quadrate, one-third longer am wider than the prothorax; siles feeloly arcuate toward ajex; disk sparsely punctate, the punctures feehly impressed, distant ly twice their own dianeters and ahout as sparse as those of the pronotum; pubescence fine, rather long and sparse. Abdomen very slightly narrower than the elytra and very much wider thạn the prothorax, finely, sparsely punctate, somewhat coarsely and sparsely so beneath. Length $2.5-3.0 \mathrm{~mm}$.

\section{California (Mendocino, Sonoma, and Santa Cruz Cos.).}

This species is allied only to gentilis, which it somew hat strongly resembles in external form, color and lustre. It is, however, a rather smaller sweies, with much sparser elytral punctuation, and much deeper and wider median groove of the prousum. The mentum is not impressed in the middle as in gentilis.

The hy pomera are nearly one-half as wide as the distance thence to the coxe and are flat, except externally and posteriorly near the lateral margin, where they are narrowly impressed; the sutures are distinct, and the coxal fissures long and widely open.

B. stabilis n. sp.-Rather robust and depressed, widest at the elytra, back; elytra dark ruto-piceons to piceons-black; legs, and antemue toward hase prate flavo-testaceous, the latter infuscate toward apex; head and promotum teebly shining, densely and somewhat coarsely gramulose; ablomen pelished, tinely and evenly reticulate. Head very distinctly narrower than the potho. rax; eyes large; surface feebly envex, not tnbereulate, the median forea rather large and feeble hut listinct; antemnal proninences feethe; snture very fine and nearly olsolete; antenuse moderate, gradually incrassate; secoml foint rather shorter than the next two combined, tenth fully one-lalf wilter than long. Prothorux nearly as wide as the base of the elytra, fully ome-third wider than long; sides in anterior two-thirds parallel and very feehly arcuate. then convergent, arcuate, feebly sinuate near the hasal angles, which are obtuse, not rounded and distinct, lateral broadly rounded and not verydistinct, apical right and narrowly rounded; apex one-third wider than the lase, botle just visibly arcuate; disk finely, sparsely punctate, the punctures rather deeple and distinct; median groove fine lut distinct. Elytra large, toward ajex, onefourth wider than the prothorax, nearly two-thirds longer; sides teelly dirergent and nearly straiglit ; surface inpressed on the suture at the base, derply, 
distinctly and densely punctate, the punctures rather fine, alout twice as Lense as those of the fronotum, and sejarated by slightly more than their own dianeters; pubescence fine, very short, rather dense, pale brownishcinerents and somewhat conspicuons. Alydimen distinctly narower than the elytra and willer than the frothorax, very finely and extremely sparsely punctate, somewhat coarely and molerately densely so beneath. Length $3.5 \mathrm{~mm}$.

\section{Pennsylrania (Allegheny Co.). Dr. Hamilton.}

The hypomera are about one-half as wide as the distance thence to the coxa and are broadly, rather fecbly eoneare, the sutures fine and distinct, the coxal fissures rather long and extremely widely open. The mentum is rather shining, broadly, feebly concare, the apex being broadly feebly emarginate.

This species belongs near amularis, but differs in its more shining, more sparsely and distinctly punctate, and decidedly wider and more transverse prothorax, the hind angles being more prominent, and in its larger, longer and wider elytra.

B. adustus n. s]). (Fauvel MS.) - slonder, sulprarallel, hack: elytra

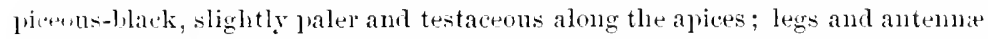
lark rufo-testaceons, the femora slightly clonded toward base; lead and pronotum alutaceous, finely, densely grannlose; elytra and alndomen polisherl, the latter coarsely reticulate, the lines rery fine, the reticulations not finer toward apex. Houl very shightly narrower than the prothorax; eyes molerate; surface feebly convex, not tulerenlate, the vertex with a small nedian inpressed fovea; epistoma tlat, more coarsely granulose; suture fine, not injuressed: antemal prominences feeble; antemne rather short and rohust, but feebly compressed; second joint more robust and fully one-half longer than the third, four to six decreasing in length, seren to ten rather abruptly wider, transverse, the latter two-thiris wider than long, eleventh ovoidal, slightly longer than wide. Prothorax very slightity narrower than the laase of the elytra, scarcely one-fourth wider than long; siltes in anterior three-fiftlis parallel and distinctly arcuate, thence convergent and just visibly sinnate to the hasal angles, which are obtuse but not rounded, am not prominent: lateral angles rounder, apical slightly obtnse, scarcely perceptibly rounded: apex ferbly arcuate, two-fitths wider than the base, the latter subtruncate: disk rather convex, not very coarsely but rather sparsely and rery indistinctly lunctate, the pminctures feebly impressed; median grove inporesed, distinct. Elytre quadrate, one-tlird wider and nearly one-lialf longer than the prothorax, scarcely perceptibly wider towan apex; sicles very teebly archate: disk rather convex, not impressed in the middle at base, rather coarsely, teebly and nut very densely punctate, the pubesconce fine, moderate in length. Abdomen slightly narrower than the elytra and wider than the prothorax, very finely, sprarsely punctate, more densely so beneath. Length $3.11 \mathrm{~nm}$. 
Colorado (Garland). Mr. E. A. Schwarz.

A small species, closely allied to ruficornis Lec., but differing in it- sparser functuation and rather shorter, more robust antenuae. The hypomera are feelly concave, two-fifths as wide as the distance thence to the coxa, the sutures fine but distinct. The coxal fissures are long and rery widely open.

B. Iauguidus n. s].-Dleutler, snbparallel, hack ; elytra piceons llack ; legs throughout testacenus; :untemie black, two hasal joints paler ; lital and pronotum feebly shining, rather coarsely granulose; efytra and abconen polished, the latter rather coarsely reticulate, more strongly so towarl hase, not more finely toward apex. Head quite distinetly narrower than the prothorax; eyes morlerate ; surfice searcely perceptibly convex, neither tuberchlate nor foreate; antemual prominences feeble; epistomal suture very tine, not impressed; anteme rather short; second joint more robust, nearly as long as the next two together, three to six suleeqnal in wirtli, decreasing in length, the latter transverse and abont one-half as long as the former, serem to ten strongly transverse, the former not rery aloruptly willer than the sixth, the latter nearly twice as wirle as lomg. Prothorar very slightly narrower than the base of the elytra, one-thind wider than long; sides in apical thirete-tifths laralle] and feebly areuate, thence broadly rounderl, convergent amb feebly aronate to the basal angles, which are obtuse, not appreviably roumber and vary teebly prominent; lateral angles obsolete, apical nearly right and extremely narrowly rounded; alpex rery feebly arcuate, one-thiril wider than the lase, the latter truncate; disk ratlee finely and sparsely punctate; merlian wronve very fine but deej and distinct; pubescence long, sjarse and flavate. Elytic nearly as long as wide, one-fourth wider and one-half Imger than the prothorax; sides feehly arenate toward apex; disk not impressed at lase, -mmewhat coarsedy and feebly punctate; finnctures impressed, diwant by ratler more than their own wirttss: pubescence cinereous, rather short, tine and sparse. Aludomen slightly narrower than the elytra, finely, very sparsely punctate, very finely sparsely punctate beneath. Length $3.5 \mathrm{~mm}$.

Oregon (Huntington). Mr. H. F. Wickham.

This is a rather sender species, allied to ruficornis Lec., but distinguished by its very much sparser pronotal punctuation, black antennæ, and less opaque lustre.

The bypomera are rery narrow, distinctly less than one-half as wide as the distance thence to the coxe, and rather deeply concare, the sutures being feeble and not very distinct. The coxal fi-sures are very long and widely open. The mentum is broadly, feebly concave, coarsely reticulate, polished and furnished along the apical margin with a short flat polished non-reticulate hypoglotti-, sepalated by a fine suture.

In ruficornis Lec. the abdomen beneath is much more densely 
and consely punctate, and the hypomera are wider and almost perfectly flat, the sutures more distinct.

B. bicolor n. sp.-Bhack; prothorax, elytra and anteme brown; legflavite: he:al and pronotum very finely, densely granulate and opacue; elytra and ablemen polished, the latter reticulate, Hrod just visibly narrower than the prothorax; eyes rather lare but molerately prominent, the setae rather long: sufile rather encex, linely and not distinctly punctate, not tuberenlate, the median forea very small and feeth:; antennil proninences feelle: epistonal suture fine, not impressed ; antenne but fiebly compressed, rather strongly incrassites; setend joint much longer and unere robust than the third, but wot as bong as the next two, three to six sulkedual in width, decreasing rapidly in length, the latter but slightly transverse, seven to ten grahlually wibler, the lormer not very abruptly so, the latter ome-halt wider than long. Irotherer sery slightly narmwer than the hase of the elytrat, sciacely onte-third wider than long ; sides in apieal three-tifths parallel and nearly straight, then convergent and broally, feebly sinuate to the hasal angles, which are obtust but not roumled and not poninent; lateral angles obtuse and rounded lout rather distinet, apieal nearly right and narrowly rounded; apex one-third wider than the base, beth suldruneate; disk finely and rather densely punctate, the functures being rery indistinet and scillecly at all inpressed, the pubescence fine, rather dense lut dark and scarcely visible; the median groeve very fint lut distinet. Elytro mearly quidrate, "ne-third wider and one-halt longer than the prothorax, very slightly wider toward apex; sides nearly straight; disk not injuressed at hase, densely and distinctly, lout somewhat coarsoly punctate, the punetures separated ly distinetly less than their own diameters; pulneseence line, morterate in length and density, einereous ani distinct. dlefomen broad, hut slightly narrower than the elytra and nuch wiler than the prothorax, finely, not densely punctate, more strongly ami somewhat denecly so leneath. Length $3.3 \mathrm{~mm}$.

\section{California (Napa (oo.).}

A rather small inconspicuous species, allied to ruficomis, hut well distinguished by its peculiar coloration, which is rery constant thronglunt a series of eight specimens. It is further distinguished hy its sexull characters, the anterior margin of the epistoma being perfectly devoid of tuberculation in the male. In the eorresponding sex of rufermis there are two remote and very small tuluereulations which, howerer, are not at the apical angles as in armatus, but distinctly nearer the midalle.

The hypomera are flat, except near the apex of the coxal fissures where they are feebly impressed; they are scarcely one-half as wide as the distance thence to the coxe, the sutures being distinct. The coxal lissules are very willy open. The mentum is exceedingly feebly concare, the hy poglottis apparently obsolete. 


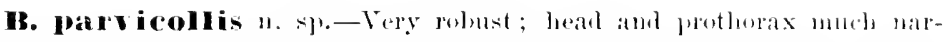

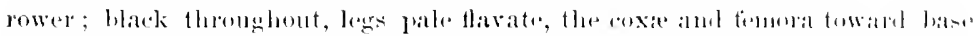

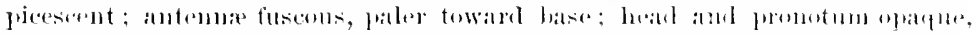

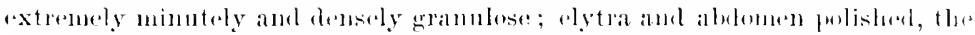

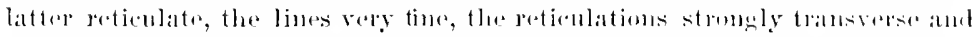

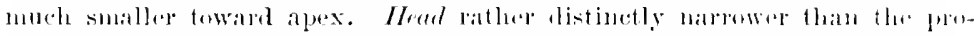

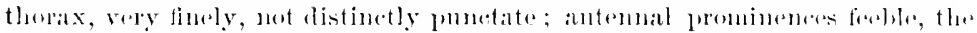

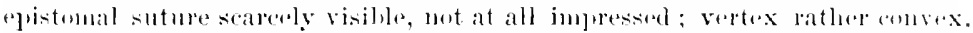

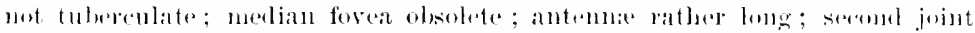

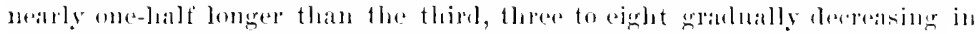

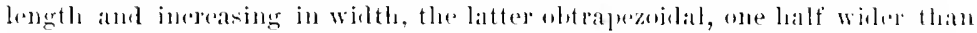

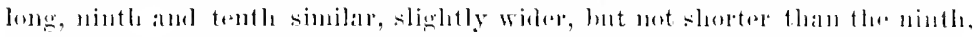

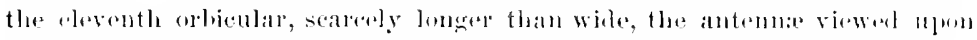

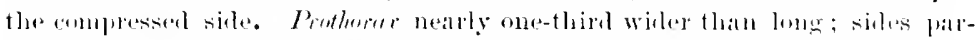

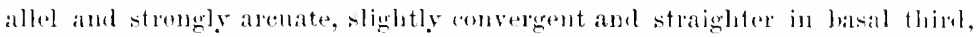
the bisal angles rery obtuse, mot at all rombled and minntely thomgle notion-

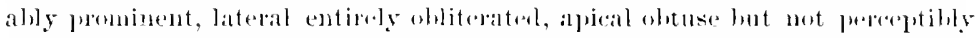

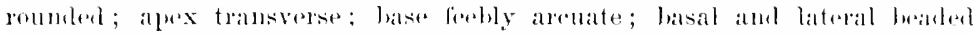
mareins distinet; disk timely, demsely and somewhat indistinctly punetate, dhe

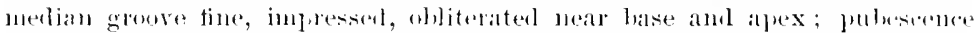

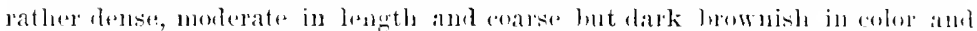

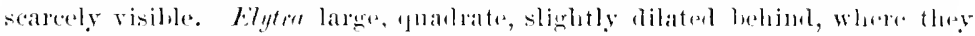

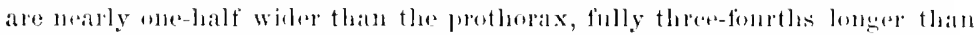

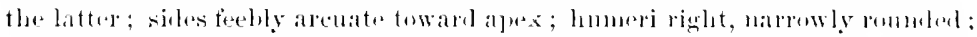

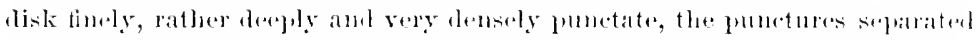
by from one and one-halt to two tintes their own dianeters; puhescoure line,

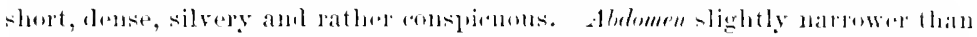

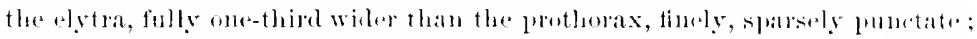

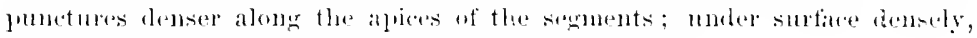

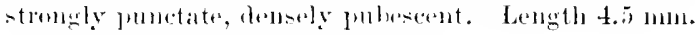

\section{California (Mendecino ('o.).}

The hypomera aw not inturesed along the lateral edgers; they are one-half as wide as the distance thence to the coxe; the coxal fistures ane very long and widely open. The mentum is latere and perferely flat, fincly, dell-ely granulose and dull, the ligpoglottio apparently rudimentaly. The prostermal sutures are distimel.

The elytra are sometimes palde, indefinitely clomeled towath the sutme. Two specimens are dreidedly mole slender. This is a very

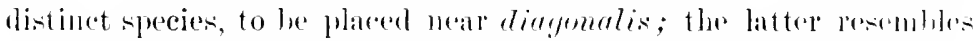
it greatly in form, lut has the surface of the head and promonum much more shining, and the basal angles of the prothorax abnar, narrowly but distinely romblesl, and not at all prominent. From longipennis it differs in its denser promotal punctuation; this palt in that species is, aceording to Manmerheim, "parce punctato."

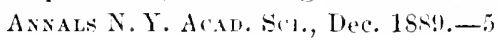


B. honestus n. sp.-Slinhtly robust, subparallel, black; elytra, legs and inteme thromglont testaceous, the first very broally and indetinitely reouled towarl the suture: lewarl and promotum strongly slining, rather rearsery and strongly reticulate: ahdmen reticulate, folished, the retal lines fine throughont. Heenl rather convex, sliglitly narrower than the prothorax, not tubcrulate: merlian forea rery small and feeblu, shining, with a few rather latre and distiuct widely-dispersed punctures; antemal tulerenlations moleratr, smontle; suture very fine but distinct; antemne rather slender; secomel joint quite rolust, nearly as long as the next two, thirel scarcely onehalf longer than the fourth, fomrth and fifth suberpal. sixth slightly shorter, feelly transverse, six to ten very evenly lont rajiclly wicler, the tenth nearly one-lalf wider than long, eleventh slightly shorter than the tro preceding. Protherer as wide as the base of the elytra, one-third wirler than lomg; sides in anterior two-thinds parallel and nearly straight, then convergent and feebly areuate, feeloly sinuate for a short distance before the basal angles, which are rery obtuse, slightly rounder and not thistinctly pominent: lateral angles very broully romded and not distinet, apical right, rery narmwly rounded; al wex two-fifths willer than the hase, just visilly arcuate, the latter truncate: disk mot very coarsely mnetate, the punctures very deej and distinctly ilefined, prarely and somewhat merenly distributed: pulnesence fine, sparse ant inconsplicnoms, the median grove rather coarse, deep and distinct. Elytir saresy as long as wille, just risilly wider and about two-fifths longer than the prothorax; sirles feebly divergent, nearly straight; surface feebly infressed near the bise and suture, rather finely and not very densely punctate. the ponctures sprarated ly about twice therir own dianeters; pubescence molerate in length, tine, ratleer sparse. Aldemen just visiby narrower than the elytra, rather more coarsely and densely punctate than nsmal, beneath rufo-piceous, shightly more rensely but rather finely punctate. Length $3.3 \mathrm{~mm}$.

New York (Catikill Mts.). Mr. II. II. Smith.

The bypomera are narrow, distinctly less than one-half as wide as the intervening coxal distance, and are strongly and narrowly concave thronghout the length, the sutures almost completely obsolete, the coxal fissures rather long, widely open, the prosternal surfice immediately before them transrersely impressed. The mentun is shining, coarsely reticulate and broadly, strongly impressed in the middle toward hase, the hypoglottis membranous, and nearly one-fourth as long as the entire mentum.

The prosternal sutures being efiaced, with the coxal fissures widely open, constitute of this rery distinct species, one of the bonds uniting the cordatus and ammularis groups of LeConte. Although the sutures are obsolete, it is easy to perceive the extent of the hypomera, as the reticulation of the surface is longitudinal on these parts, and withont definite arrangement elsewhere. 


\section{Group 5.-cordatus.}

A rather limited group containing the smallest speries of the genus, polished, sometimes dull, black, with the elytra always pale, white or yellowish-white, elouded towark suture and base with brown, piceous or black:-

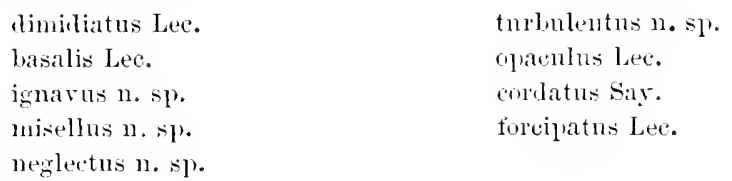

B. ignavus n. s1.- Slenter, rather convex, parallel, black: elytra very rale, whitish, translucent, indefinitely doucled with pieens towarl sutnee and at the hase; lego picenus, tihice and tarsi flavate; antemne flavate, piceous towam apex; integments polished thronghont, head amd prothorax very finely reticulate, the retienlations on the latter tending to a transterse arrangement; abdomen more coarsely reticulate, the lines very tine. II ow distinetly narower than the prothorax, very convex, neither tuberculate nor foreate, rather finely, distinctly and sparsely punctate; antennal tulereniations extremely sull and feehle; epistomal snture fery fine, feeble, not impresserl; anterior angles of the epistoma very minutely lont acntely and listinetly tolnerculate; antemne rather slert, gralually and very strongly incrassate: somol joint rolmst, longer than the rext two together'; three to six snall, sixth strongly transverse, eighth twice as wille as long, shorter than the ninth and tenth which are rather strongly transverse, eleventh ovate, scarely longer than wille. Protlencex as wide as the elytra, nearly one-half wirer than long; siles in apical two-thirds parallel and very nearly straight, then very hoally rommled into the base, withont lateral or hasal angles; botse subtransterse in the midlle; apex bually ewenly and just visibly arcuate: apieal angles right and narrowly but distinctly rombed; disk rather strongly, evenly, transversely convex, very finely, evenly and sparsely punctate; melian growe rery fine but distinet, not quite attaining the apex. Elytre quarliate, alont twothirels longer than the frothorax; sides nearly paraliel and straicht; ontor angles very loroally rounded, inner narrowly but distinctly so: surface not distinctly inglessed near the hase, rather coarsely, very feelly and somewhat densely punctate, the punctures separated by their own wirths. Aludomes sliorlity narower than the elytra; sirles parallel and feely arenate; surfiac finely, sparsely punctate, leneath rery minntely and sparsely functite. Length $1.9 \mathrm{~mm}$.

\section{Rhode Island.}

The hypomera are flat but depressed below the lateral extges which are, therefore, finely prominent; the coxal fissures are rery short and narrowly open, the sutures obsolete The mentum is 
very -lort, twiee as wide as long, shining but coarsely confuserlly reticulate, hroally, feehly emarginate throughont the wisth at apex, with a narow inpresed transverse groove just hehiud and along the aprical matrin, and a small deep abrupt impression in the middle at the hases, deewhere convex and slightly tumid.

The description is taken from the make, the eighth segment having

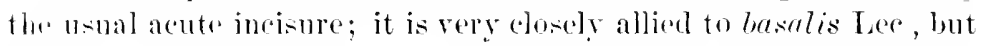
differs in its smaller size, nore transverse and more sparsely puncetate pothorax, in which the anterior angles are less prominent, and its shorter, nore coarsely and mueh nore feehly punctate elytra in which the exterior apical angles are more broadly rounded. In hasulis the mentum is truncate at apex, feebly impressed in the centre, the surface on rach side of the impression forming a rounded tumid elevation. It is totally devoid of the small round forea near the base, which is so marked in ignavus.

B. misellus n. -p.--Rather slender, hack: elytra very pale, whitish, the hatsal third piceons-brown, the same tint extending broally along the millde nearly to the a peex: legs and antemne very pale, the latter infuseate: timma daker; interuments jolishol, exeret the elytra reticulate, the abdomen coarsely so, the lines very fine, the promotum more finely so, with the roticulations tending to a transwerse arrangement. Ifed rather distinctlynarrwer than the prothorax. strongly convex, neither tuberculate nor toreate, ratler finely lout distinctly and sparsely punctate; antemal pomineness very

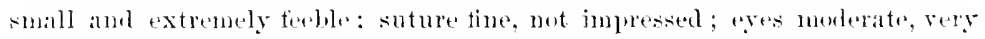

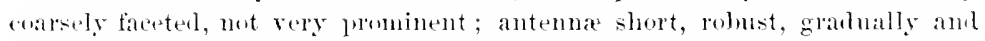
strongly incrasisate, rather strongly compresseul; seape as leng as the mext six juints conlinerl ; secoml joint nulleh longer than the next two, all the joints after the third transterse, sllecessively more strongly so, compactly placed, the

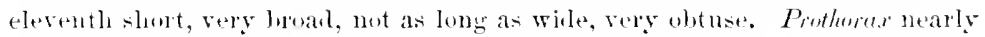
as wille as the hase of the elytra, ne arly two-lifths willer than long; sifles in apinal three-fomrths parallel and nearly straiglit, then alumptly, hroady romuded into the lase without lateral or hasal angles; hase transverse: apex truncate, the apteal angles aente and slightly anteriorly frominent. finthy remuled externally: disk transwersely, rather strongly convex, vely tinely themgh distinetly, sparsely punctate, the median groove rery time, rather feebly inupressed and not quite attaining the alex. Elytra slightly longer than wide. two-tiftls wiler and fully fimm-tifths longer than the protherax: sides just

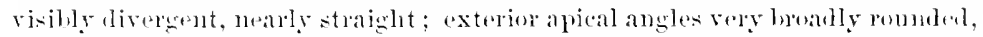
interior extremely narrowly so; surface fixelly inpressicl near the snture toward laser, rery fimely, fielly, not very distinctly punctate, the pumetures generally spatrated ly lentween two and three times their own dianeters: pulnewere extremely shont, sparse and inconspicuous. Alelomen distinctly narrower and sarcely longer than the dytra; sides rery feebly convergent 
from lase to apex and very foebly arenate, very minutely and slorsely punetate, lineath minutely, rery sparsely punctate, the pubescence longer and more distinct. Jengtl $1.8 \mathrm{~mm}$.

\section{Texas (Galreston).}

The hypomera are feebly impressed along the sides and are rather wide, the sutures obliterated, the coxal fissures short, almost comipletely closed. The mentum is short, fully twice as wicle as long, broally, feehly cmarginate at apex throughont the wirth, deeply and coarsely foreate in the mildle near the base, the surface distinctly tumid on either side of the fovea, and having a few coarse setigerous punctures.

Althongh to be classed with basalis, this little species, one of the smallest known in our fauna, is not very closely allied to it. The elytra are relatively larger and longer, and are much more finely punctate. The sides of the prothorax are straight in apical threefourths, while in basalis the parallel portion of the sides is nuch shorter. 'The series before me exhibits great variation in the extent of the brownish-piceous tint, this being confined in one specimen to the basal margin.

B. neglectus n. s].-Slember, hack; elytra very thin and translucent, whitish, the suture and base blackisli ; legs and antenne testaceons, the latter

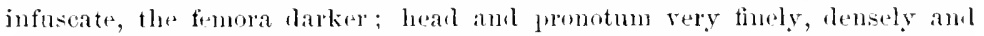
eventy granulatoreticulate, rather foelyy shining : abdomen polished, coarsely reticulate, the lines fine. Hend much natrower than the prothorax, convex, neither fireate nor tubereulate, finely, rather feelly and sparsely punctilte, the median fortions impunctate; antrunal promineness very small and feelle; eyes modrate; ejistomal suture fine; epistoma with a the distinet tulerele: on the apical erlge near each anterior angle; antemne moderate, rather stromgly complesised, gratually and strongly incrassate; second joint sliglitly longer than the mext two together, fifth qualrate, rather lomger than either the fourth or sixth, six to ten wider than long, the latter by three-fourths its length, eleventh very slightly wider than long, wry olduse: joints thronghout not very compratly joinell. Protherax nearly as wille as the lase of the elytra, two-lifths wider than longr sirkes in anterion three-fourths parallel and straight, then very stromgly convergent and broaly, feebly but distinctly sinuate to the basal angles, which are olstuse and romeded but rather distinet, lateral more broally rommed and less distinct, ajical right, very narrowly rombled, not at all poninent; lase and apex transvorsely trumate; disk transversely, umde-

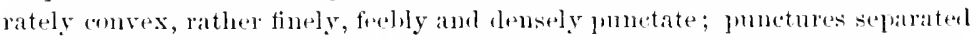
ly nearly twice their own widths; neelian greose very tine but distinct. Elyter quadrate, two-thiris longer and one-third wider than the pothorix; sides nearly straight, feelly divergent: surface distinctly inperessed near the suturt at base, finely, rather feebly and densely punctate; pubescence extremely 
shent. Dhdemen listinctly narower than the elytra; siles parallel and nearly straight, a littlr more convergent toward apex : surface very finely, sparsely functate, beneatle minutely amb starsely so. Length $2.5 \mathrm{~mm}$.

Rhode Island.

The hypomera are very wide, with the sides parallel, flat but depresied far below the lateral edges, so that the latter are rery acute and prominent; the coxal fissures are extremely short and appear to be rery narrowly open, the hypomeral edge heing heweath the prosterual or antrior edge. The mentmm is nearly flat, the subhasal median impresion being somewhat feelle.

This species belongs in the neighborhood of basalis, but differs in the form of the prothorax and sinnation of the convergent portion of the sirles, and in its rather distinct basal angles; the elytra are more finely and densely punctate and the size considerably larger.

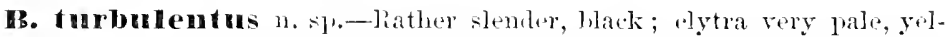
lowislo-white, the latsal margin picens-black; legs and antenne testaceous, the temora darker; intermments pwlished, head and prothrax finely, erenly ans rather stromely reticmlate; alutemen coarsely retioulate, with the retal lines very fine. Heal distinctly narrower than the prothorax, convex; eyes ratlue large and frominent; surtace finely, rather feelly and sparsely junce tate, neitler foreate nor tubereulate; antemnal prominences small and very feelle: suture fine, not inpressed; epistoma with a fine apical tulswcle near each anterion angle: antrune ratler slenteri, evenly incrassate; second joint not very rolnst, crlindrieal, slightly longer than the next two together, fitth distinetly donger than wirle, eighth and nimth similar in form, the latter the latger, just visibly wiler than long, tenth slightly shorter than the ninth, less than me-half wider than long, elerenth not quite as wide as the tenth, lis-

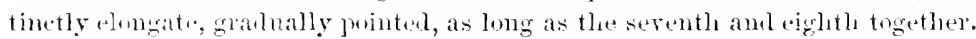
l'mothorer nearly as wile as the hase of the elytra, two-titths wider than long; siles in anterin two-thirds parallel and straiglit, then enrergent and rery formly aremate to the basal angles, whieh are very obtuse and lroally rommled

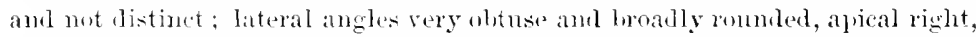
net risilly romelen and just jerceptibly anteriorly prominent; apex transviprely trumate; hase very foebly arcuate; disk transtersely, molerately comvex, timely punctate, the punctures rather feebly impessed and somewhat donse, lwing separated ly scarcely more than twice their own diameters: menlian groore very fine, feebly inpressed, not attaining the alex. Elytrm quadrate, two-thirds longer and one-fourth wider than the prothorax; sides nearly straight, just visilly divergent; onter angles rather lowally, immer very narrowly romuled; suface feebly inpressed near the sutme at base, tinely, feetly and densely punctate. Aledemen distinctly narrower than the rytra, as witle as the protlumax: sides parallel and nearly straight, the sixth 
segment listinetly narrower from hase to apex : surface fiuely, sparsely and unevenly punctate, beneath rather densely so, especially toward base. Length $3.11 \mathrm{~mm}$.

Florida. Mr. E. A. Sehwarz.

This species was confoumler by LeConte with basalis, from which it diflers in many conspieuous characters, and chiefly in its much longer, more slender antenne, these in basalis being very short, the outer joints rery strongly transverse and more eompactly connecterl, the eleventh very short, obtuse and much wider than long, the fifth widler than long; it also differs in its much more finely and densely punctate elytra, and in its decidedly greater size. Jiasalis is ruite uniform in size, the series of six specimens before me offering but slight variation in this respect, the length being 2.0-2.2 mun., and not as great eren as the minimum length (2.5 mm.) given by Dr. Leconte in the original description. The present deseription is taken from the male, and it has been compared with the same sex of basalis.

The structure of the under surface of the prothorax is nearly as in basalis, the coxal fissures being very short and entirely rlosed. The mentun is flat, with a large deep impression in the niddle near the base.

\section{Note.}

In the list of Staphylinide publisher since the date of the Munich Catalogut,

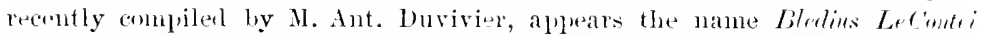
Duvir., for B. phytessinus Lee., nuter the supposition that the latter name was

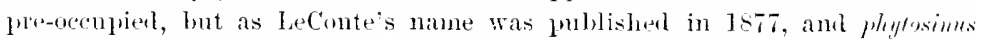
Fanvel not mutil 16-8 (l. e. p. 101). it is evidently the lattor which shouh fall and not phyfosinus Lee. The name Bledius LeContri has recently been given

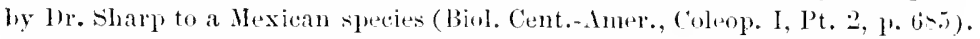
The Faurelian speecies must be consilered therefore as still unnamed.

\section{APLODERUS Steph.}

Inolorkrus Lac., Lee., etc.-Phlomens Er., Lee.

The species of Aploderus are eomparatively few in number and

1 The alteration of the original name Aploderus as pullished by Stephens, to Inaploderns, is nuwarranted by any rule of nomenclatnre based upon solid reason. 'l'o legitimize the changing of a name once given by an anthor, eren by the purists, is to open the way to nnending confusion, and shouhl not be enconraged. The sense of the majority of modern authors secms to farm, or 
somewhat resemble Trogophleus in external facies. They are at once distinguishable, however, by the extremely large, externally angulate and open anterior coxal carities, the open portion berond the roxe having a large trochantin or plate, which probably serves the purpose of an operculum; they also differ hy having a row of shurt rather robust and listinct spinules along the outer edere of the anterior tibia. The genus is rather closely related to Ancyrophorus, the latter being distinguished by the visible scutellum and rather longer and more conical fourth joint of the maxillary palpi. The aflinity with Oxytelus is much more remote, not only in habitus, hut in the special modifications of structure.

The eishth rentral segment of the males, as usual in this portion of the Oxytelini, is longitudinally divided thronghout its length, forming two listinct parts which overlap. In the present genus the orculapping edge is parallel to the axis of the body, and the

at leat tolerate, the aroption for generic nanes of any combination of letters which is mollerate in length, easily pronounceable, and which has a Latin form w habitus so to speak, and although Aploderus may mot be as good Crees as IIaplonerus, it is at all events a certain lefinite combination of letters, having a Latin form, and easily pronounceable, and could not be altererl eren by the anthor limselt.

Atthngh generic names are generally taken or derived from the freek, they (ease (1) he tireck and hecome Latin as, soon as published over a descriptim, and Aploxlerus is as grood a Latin worl as Ilaploferus, or Bledins, or Hamberia. Theomly season for aitering a name once published is because of a trographical error which may elther delatinize it, or render it mupronounceable.

If generic names le not considered as Latin simply and solely, we are continually guilty of a "barbarism" of the worst kind-the modification of a (ireek word by a Latin adjective. It being granted therefore that generic worls are latin and not treek, it follows that the gender of specific names should depend npon the ending of the generic name in its Latin sense, $i . e$, words ending in $"$, is, and $e$ are feminine, $\%$. . Tyloth rma reet and not "remm. Cufortunately there are many words used for genera which are perfectly Greek in form and not Latin; in these cases the only course to pursue is 10 give to the specific names genders which coincide with the Latin equivalent, e. \%., 1/eden fiucculme and not fusculus.

The reason given by LeConte for the suppression of Aploderns and the substitution therefin of Phluonens Erichs., is not, in the opinion of the writer, a valid one. As loner as a certain definite deseribed species is stated by an anthor to be the type of a genus, the genus must be considered established, even thongh not describet. 
apex is therefore neror dreply angularly incised, as would lw the aso when the two edges are oblique, as in Bledius.

In the table and lescriptions given below, the specific characters throughout are drawn from the male only.

The spereses belonging to our fauma, although as far as known only five in number, are easily divisible into two distiuet gromps as follow:-

Anterior coxal arities pxtremely large, angulate, extending to within a shont distance of the lateral edgers of the prothorax, this distanee being not greater than the distance separating them from the anterior margin of the prosternum ...................................................... I

Ilead and prothorax narower than the elytra; eyes molterate, the temprora belnim them efually frominent and hot slightly longer

lincaris

lleal and prothorax as wite as the elytra ; form paralled; eyes very suafl,

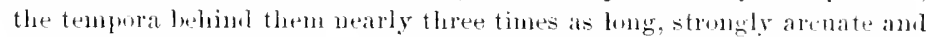
murh nore proninent

ceplinilotes

Anterior coxal cavities smaller and shorter, broally triangular, the hypmera wille, the distance separating the cavities fiom the lateral margin of the

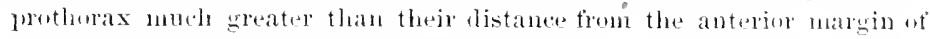
the prosternum

Heal chllal in width to the prothorax or extremely nearly sor batal joint of the antemne sulnewall in length to the next three tougether; elytra clistinetly less than twien as long as the prothorax.

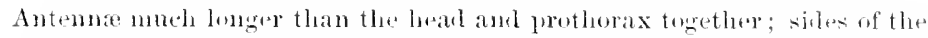
alskenen straight and feebly divergent from base to apex....princeps Antenne about equal in length to the head and prothorax. the jointe nume

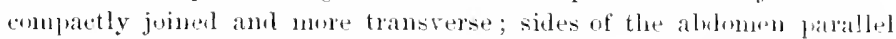
and erenly, distinctly arenate throughont.

flat iperanis

Head slightly, although distinctly, nalrower than the prothurax ; basal joint of the antenne sherter, sulwoual in length to the mext two together: elytra alent twien as long as the prothorax; sides of the alulomen parallel itnd straight

anducetens

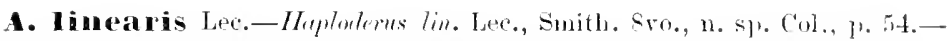

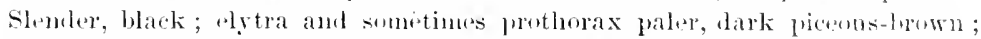

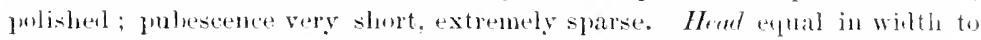
the protherax; eyes morlerate, nearly equal in length to, and rather more convex than the tempora lehiml them. the latter as prominest as the eye:

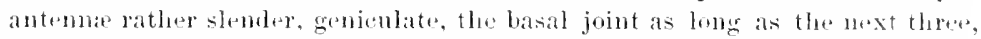

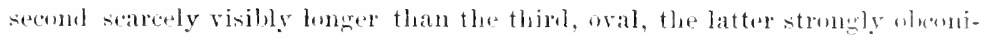

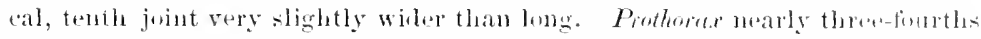
widre than long; sides strongly arenate anterionly, teethy enurergent and straight toward hase, the batse and apex lroally arenate; basal angles

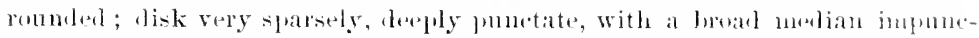
tate line, on eitler side ol which there is a narrow, feeble and ratler indelinite 
longitulinal impression. Elytru qualrate, one-thirt wider and alont threeformth longer than the prothorax, hensely, very deeply and somewhat coarsely punctate. Ahdomen nurow, much narrower than the elytra; sides straight and parallel ; surface extremely minutely and sparsely pumctate.

ldole.-Sixth ventral segment with a very litrge melian area, which is flattened and finely densely pulseseent; seventh hroakly, feelly emarginate thronghout the wilth at apsx, the midlle of the emargination feebly produced in a short roumled process.

Fimele. - sixth segment not densuly pulesent; serenth not emarginate,

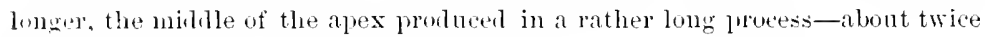
as wille as long-which is strongly arcuate.

Length $2.7-3.0 \mathrm{~mm}$.

California; Oregon; British Columbia.

An extrenely common species, easily separated from the next by it- relatively longer and wider elytra and many other characters.

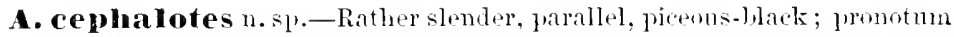
rufous; elytra laler, flarescent; legs pale tlavate; antemne pieeons-black througlont; integuments pulisherl ; pubeseenese very short and sparse. Ileal larwe orlicular, slightly witer than long, as wide as the prothorax, feebly convex: transverse basal line finely, feebly impressed ; surface tinely, feebly, very sparsely punctate, with a short fine very feeble canaliculation in the miklle nearly attaining the transverse groove; antemal prominences short, rather wide and rather strongly elevilted; ryes rery small, feebly convex, the sinles behint them almost three times as long, strongly areuate and much more prominent; antenne fully as long as the learl and prothorax together, feelly incrassate, seemd and third joints suluegual, tenth rather distinctly transverse. Prothore nearly twien as wille as long; siles nore strongly arenate anteriorly, strongly convergent and frelly arenate toward base, the latter broally, distinetly arenate, the basal angles very broally rounded, apical aeute, not at all rommed, and slightly anteriorly prominent; apex truncate; disk not distinetly inpresied, not very coarsely or denply, very sparsely and nuevenly punctate, a broal mislian line imponctate. Elytre puidrate with the sides parallel, equal in width to the prothorax and one-half longer, charsely, very deeply and densely functate, a narrow line on each, near the sutnre rather deeply impressed. Aludomen nearly as wide as the elytra; sides prablel aud very slightly arcuate; surface very minutely, sparsely punctate.

Mole.-Sixth ventral soment with a very large median area which is distinetly flattened, and covered very densely with fine ereet pubescence; seventh hroally, ferbly emarginate throughout its width, the midelle of the emargination not in the least prodnced; eighth with a narrow elongate impression.

rimale.-I'nknown.

Length $3.0 \mathrm{~mm}$.

California (San Franciseo).

This is a remarkable species, its slightly transverse orbicular 
bead, with very small cyes, and long strongly areuate trupora, its parallel form and relatively smaller, very coarsoly punctate elytra, at once distinguishing it from any other.

A. princeps 11. sp-Clather convex, parallel, pale flavate thronghout ; lusal slightly tarker, fuscescent; antenne feelly infuscate towarl alpex; integuments polisher ; pulescence sparse but rather long and distinct. Ilend fully as wide as the prothorix, rather strongly and densely punctate exicht in the millle and anteriorly; punctures morlerate; median post vertical impression feeble; nuchal constriction very strong; eyes molerate, slightly frominent, the tempora nearly twice as long, strongly arcuate and a little more lowninent; antenne rather slender, feebly incrassate, distinetly longer than the lead and prothorax; hasal joint subequal in length to the next three, second very slightly longer than the thirt, sixth fully as long as wille, tenth rather longer than wikle and wider than long on the unconpressed and c..mpressed sides respetively. Prothorax three-fifths wirler than long; sindes lroady, obtusely sulangulate at anterior third, thence distinctly eonvergent and nearly straight to the broally romded basal angles; base breally sul,transwerse: alex very bromly, feebly arenate ; apical angles slightly obtuse and scarcely pereeptibly rounded, not at all prominent; hisk strongly, areuately inpresser on early sile of the median impmetate area, the impressions abruptly reflexel and contimuing anteriorly nearer the sickes, indosing an impunctate callus; elsewhere rather strongly and itensely punctate. Elytom about two-fiftlis wider and two-thirds longer than the prothorax, not cuite as long as wile, strongly impresset along the suture toward base; disk rather droressetl, rather coarsely, derply and densely punctate, the punctures generally separated by a little less than their own dianeters. Aldemen just visibly increasing in wilth from base to apex, slightly narrower than the tytra; siches straight; surface very finely, sparsely punctate, just perceptibly clouled with fuscous toward apex, the latter arain paler.

Male.-Sixth segment very broally areuately emarginate throughout its wilth, the edge in millle third fimbriate with a line of excessively short and ninute pointed membramons hairs, the surface with two diverging tufts of long sete, the intermediate luanlly triangular apical portion scarcely impressien lout devoid of jubesence. Serenth sogment broadly, angularly emarginate, the surface having in miklle two-fifths a transverse strongly and posteriorly angulate line of densely placed oblicpely indined spinose sette, the anterior incleser surface feebly impresised and deroid of pubescence; surface laterally, lwyom thre line of sote, having numerous very long stiff bristles. Eighth serguent nearly normal, not inupresseel.

Female.-Cnknown.

Length $4.4 \mathrm{mmn}$.

\section{Nevada.}

In its wonderfully distinct sexual characters, large size, pale coloration and longer pulsescence, especially of the pronotum, this 
is hy far the most remarkable species of this section of the genus. There are but two specimens known, and the male above described I owe to the kindness of Mr. C. H. Roberts, of New York.

A. Invipenmis n, sp. - Somewhat robust, but moderately depressen; hear black; pronotum dark rufo-piceons ; elytra pale flavate; ablomen piceous thromghnot; legs pale flavate; antemne piceons-lolack, the basal joint very dark rufi-testacenus; integuments polished, very finely and extremely sprarsely pulresent. Hewl as wide as the prothorax; eyes rather small, sonewhat convex, the tempra about three-fourths longer, less strongly arenate but rather nore frominent; transverse basal inpression distinct; surface fechly convex, finely lut distinctly and rather densely punctate, a wisle median area injunctite; antennal prominences strong lont suall and very short; antenuat rather slemeler, very feehly incrassate, as long as the head and lrothorax, hasal joint alwut exual in length to the next throe together, spend scarcely visibly longer than the third, tenth very slightly longer than wide. Prothorar fully threefourths wider than long; sides near the apex broadly sulangulate, the angle narrowly rounded, thence feebly courergent and nearly straight to the apex, slightly more strongly so and very feethy arcuate to the basal angles which are roumded ; base subtmote toward the middle; a pex broally and distinctly arenate, very feehly sinnate near each angle, the latter very slightly ohtuse, very narowly rounded, not prominent; aisk strongly impressed in the middle at each sile of the impunctate median line, the impression reflexed posteriorly and extending thence anterimly mearer the sides, hecoming broader and feebler and not attaining the ale $\mathrm{x}$; internediate callus smoth, impunctate; inpressed areas finely, rather lensely punctate. Elytro slightly wider than long, wethinl wider and nearly three-fourths longer than the prothorax; sides nearly parallel and straight; surface with a strong elongate impression at each side of the snture at hase, rather finely deeply and densely punctate. Abutomen rather distinctly narrower than the elytra; sicles prabllel and very distinetly areuate; surface very minutely and extrenely sparsely punctate: under surface nore densely so and with rather long cinereous and conspicuous yubescence.

lale.CSixth ventral segment with a very small narrow elongate-oval area, not attaining the apex, which is more densely and tinely pubescent; serenth very hoadly, findy emarginate throughout its apical wilth, the millle of the emargination transverse; eighth flattened bnt not impressed.

Femule.-Seventh segnent very boally arenate, the melian portion with a fringe of very fine forrected membranons hairs; eighth broadly impressed.

Length $3.4 \mathrm{~mm}$.

\section{(alifornia (Mendocino, Santa Clara and Monterey Cos.).}

The specimens before me consist of a single representative from each of the above localities-one male and two females. The speres differs from amnectens, not only in the characters giren in the table, but in its sluorter and rather more coarsely punctate ely tra, and in the sexual characters of the female. 
In the male trpe above deseribed, there is a stout spinose setat at the posterior extremity of the pubescent area of the sixth segnent; I annot determine whether this is accidental or not.'

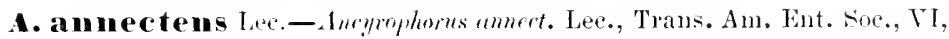

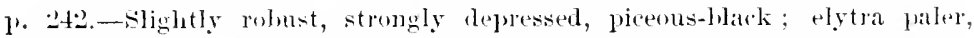
rufo-picenss; legs pale llavate; antemine piceons-blatk, fuscous toward base; pulnsence extremely fime and sparse, much less sparse on the elytra; integnments polished. Head rather distinetly narrower than the prothorax, feebly convex, feebly and sparsely punctate, a wide median area impunctate: eyes moxlerate, rather comrex, the tempora one-half longer and a little lesos convex than the eye, althughle equally lroninent; transverse basal imumession strong; wertex not impressed in the mithle; antenne hong, evenly and rather thistinctly incrassate, a little longel than the heal and prothorax together, strongly genieulate, basal joint alout as long as the next two together, the latter subecpnal, tenth mearly as long as wide. Prothorex three-fourths wider than long, transversely truncate at base and apex; sides ohtusely angulate near the apex, cunvergent ame nearly straight to the apex and base; basal angles distinetly rommled, apical nearly right and just visibly romded, not anterionly prominent; disk broadly, ratlee feeloly, somewhat indefinitely and arcuately inpressed on each sille of the rather narrow median inpunctate line, the latter withe near the apex; prumetures nomerate, somewhat dense in the impressed areas. Elytra one-third willer than, and nearly twiee as long as the prothorax, quadrate, depressed, hroally impressed in the midtle at hase, ratler finely distinetly and demsely punctate. Abdomen distinetly narower than the elytra; sirles straight and prarallel.

1hale.-Sixth segurent normal, without trace of denser fubescence in the midhle; seventh extremely hoully and feethy emarginate at apex, the midlle of the emargination just visibly produced and areuate; eighth not injeressed.

Irimele. Serenth segment longer, broally roumed at apex, the mirthle of the apex with a very feedle sinuation, the margin of the sinnation lined with a tringe of short, lorrected, semi-membranous or gelatinous hair's; cighth implrested.

length $3.5 \mathrm{~mm}$.

\section{California (Sonoma Co.).}

A wider, more depressed species than the preceding, and apparently somewhat rare. The series lefore me consists of five specimens, all taken at Fisk's Mill on the seacoast.

1 Since writing this paragraph I have received one other male example from Alaneda Co. The spine is rery distinct and in the same position, but insteal of a single spine, there is here a closely comlensed clump of fire or six stitr setie. The aplearance of a single still spine in the original type is probably due to the complete agglutination of these setat. The head in the Alamerla male is, however, quite distinctly narrower, and this partieular specinen may pussibly be less fully dereloper. 


\section{THINOHIES hies.}

This genus, althongh allied somewhat to Trogophlous, differs in three very important structural characters, viz: the risihle seutellum, hroadly rounded imner apical angles of the elytra, and antemnal structure, the fourth and sixth joints of the latter being invariably smallor than the fifth and seventh. These differential characters are rery constant throughont our species, and there are no others which I have observed of sufficient importance to warrant the creation of a new genus. 'There are, however, certain characters possibly of sulgeneric value, which shonld at least be noted.

In croul I, the pulsescence of the elytra is of dual composition. The very densely placed punctures bear, each, a very minute recumbent and searecly visible seta, sometimes quite robust, and which constitutes the principal part of the restiture, but, in adlition, there is a system of longer erect and much more sparsely distributed hairs. In the other two groups here indicated, there is no sign of this complexity, and the pubescence is uniform throughout, consisting of finc erect or suberect hairs, all of equal length. It should also he stated that in groups I and II, the sixth ahdominal segment is equal in length to the fifth, while in group III it is very much longer.

The European species are divided by Rey into sections which are considered of generic value. The species here noted under grom, I, seem to be entirely congeneric with the true Thinobius of Rey (IIist. Nat. Col. Fr., Oxyt.), but the 'Thinophilus of that author is alnost certainly not represented in our fauna, at least there is no species known to us at present, which possesses the cephalic strueture indieated as a prominent character of that genus (l. c. Plate VI), and should our groups be considered of subgenerie value, as they might with poswible propriety in a general monograph, they must receive new names.

The speeies are probably numerous, but owing to their very mimute size they have been alnost totally neglected by our collertors. Those at present known to me may be identified by the following characters:-

Antenne molerate in length, scarcely ever much longer than the head and prothoras, with the outer joints rolust, the last oroidal; integuments very minutely and densely punctate, or punctato-rugulose and dull ..... I Antemne tlarate. 
Elytra twice as long as the prothurax, or very nearly so.

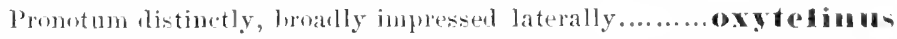

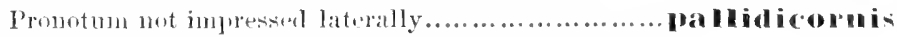

Elytra mot nore than ome-laalf longer than the prothorax.

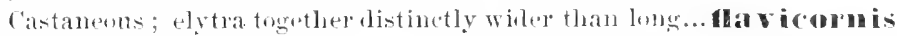

black, Hytra pualrate...

grosind111

Antenne blatek or pienons-blate.

l'ronotum not pereeptilly injerested.

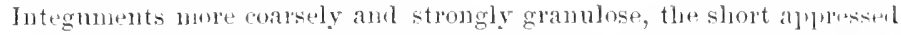
pubescence bright tulvous in color.

Hacionteris

luteguments mueh smoother, not gramulose but excesisively minutuly

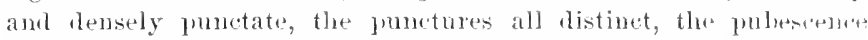
lark cinertons and not at all conspienous

..somonima

promotum with two small, feeble but distinet impressions near the hatal margin.

Castaneons or piconos, the jonctures glanolose and sulwonthurnt.

form rather robust ...................................

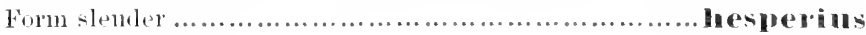

Black, the punetures mot guite so dense, and the lustre mores shining.

ID grmatus

Antemne very lomg am slemaler, ontor foints elomgate, the eleventh alongate,

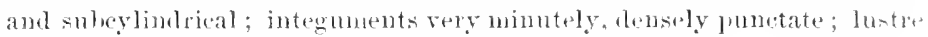
alutaceous

Size large, $1.7 \mathrm{~nm}$; elytra very short, one-fonrth longer than the furothorax

antemuarins

Size smaller, mot excresling $1.5 \mathrm{~mm}$.

Pale hown; antenuce pale tlavate.

ballidus

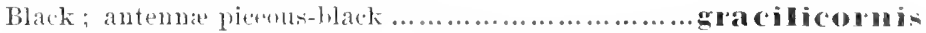

Antemne very short and rohust; integuments shining, coansely and munt? sparsely pmurtate.

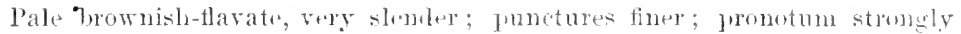
intressed along the lateral edges; antemnal joints very stronerly transverse

cuassiconlus

Black, more rolust; ponctures moleh coarser and relatively densere; for-

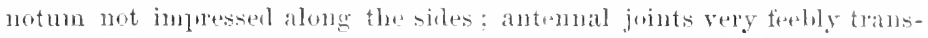
verse

ralias

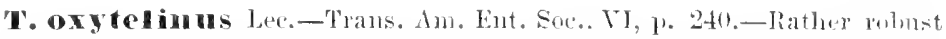

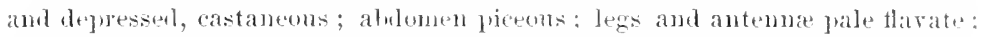
integuments dull. Ilral almont as lomg as wile, festhy confex, rery minutuly and densely pronctate, the punctures distinct aud just visibly separatei, the

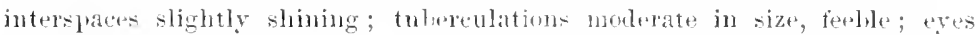

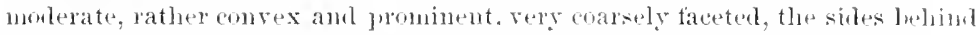
them distinctly convergent to the neck. and resy slort; antemme a little longer than the hearl and prothorax, rather slender, distinctly davate, secoul joint cylimdrical, more than twiee as lomg as wikte and fully as long as the next two, third distinetly longer than wide, fourth just visibly longer than wile, 
slightly longer than the sixth and distinetly shorter than the fifth, the latter

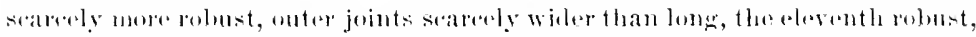

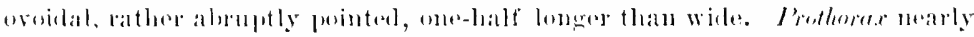

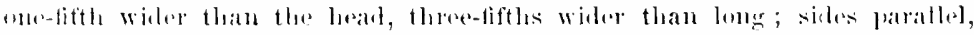

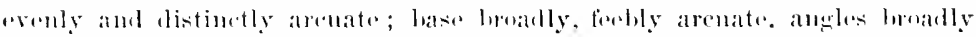

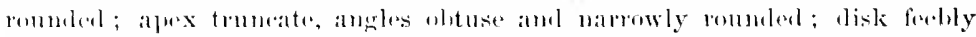

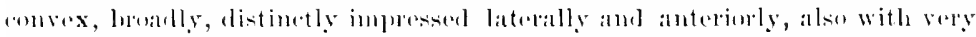

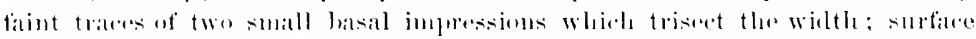
pumetured like the heat. Elytme nearly ome-fomth wider thas the prothorax

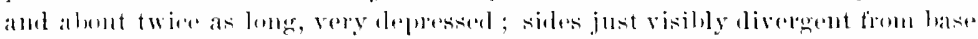
to

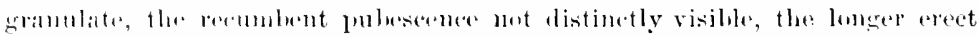

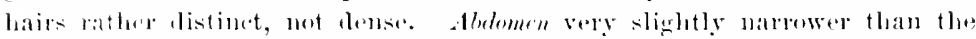

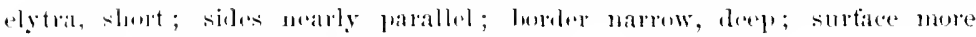
coarsely, sparsely punetate and slightly shiningr. length $1.0 \mathrm{~mm}$.

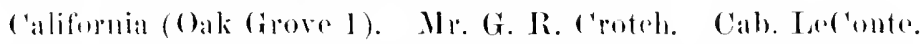

In the lype-sperinem there is mot the slightest trace of an im-

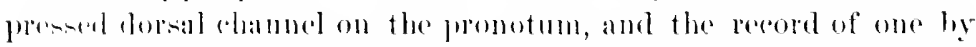
Leconte is an inalvertence. The elytra ane distinctly paler, rufescent, and pratetieally uniform throughout the surfare, the duskiness of the has and mareins spoken of in the original description being not ranly evident. This is a rery tistince species.

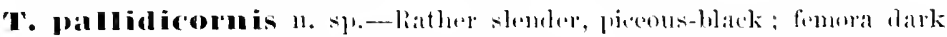

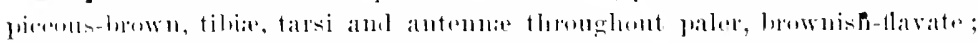

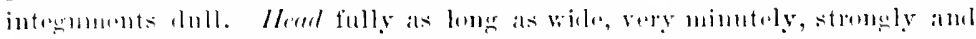

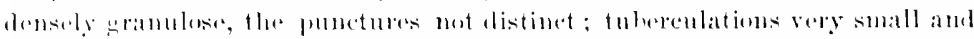

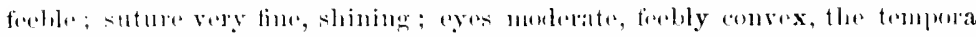

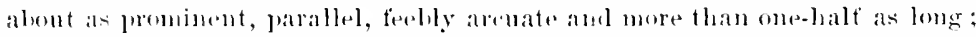
antenuir alwolt as long as the heat and potherax, slightly robust, rathes.

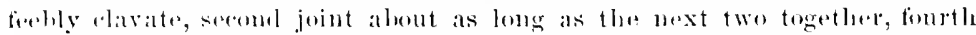
and sixth subergul, smalter than the tifth and rery slightly wider than long, onter joints slightly transwerse, eleventh woidal, alsuptly pointed, scarcely mere than one-thind longer than wide. Potheres slightly wider than the

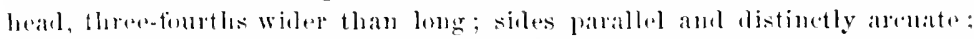
hasal asughes obsolete, very broally rommled into the base, the lattere in the

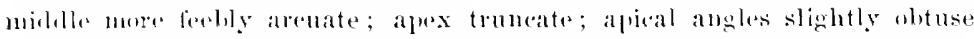
and sot distinctly rounded ; disk with very faint traces of two parallel im-

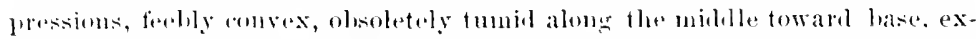
tremely minntely and densely punctate. Elytre parallel, one-fourth wisler and forme-fifths longer than the prothoma, excessively mimutely and alensely, and ratter strongly punctato-granulese, the lunger suberect hairs very minute and rather spatse. Alumen slightly narrewer than the elytrat decidedly narkwent toward apex ; horder rather thin, moterate in depth ; surface feebly 
convex, very finely and rather more sparsely punctato and less dull, the sixth segmont shining and with a transverse row of erect discal setal. Legs molsrate. Length 0.8 mun.

Trexas (Austin 1).

Trey easily distinguishahle hy its small size, piceous-blarek color, with pale antenne, and more strongly granulose integuments.

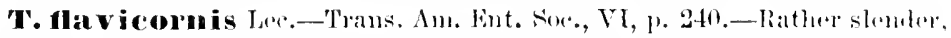
somewhat pale, eastaneons; abdomen piceons-black; legs and antenule throughont pale flavate; integuments alutaceons. Ifoed nearly as lougr ats wirle, very feebly convex, excessively minntely and very densely pmetate: tuberculations very suall, ratleer feeble, wilely distant; suture distinct: antenue as long as the hoad and prothorax, rather whust, very foebly incrassate, seromel joint searedy twice as lomg as wile and harely ats long an the mext two together, third decirledly longer than wisle, fourth and sixth qualrate and but slightly smaller than the fith, onter joints just visilny transverse, eleventh ovoidat, gradually pointed, throe-fonthe longer than widn; ayes moderate, ferehly convex. Prothorer very slightetly willer than the head, slightly less

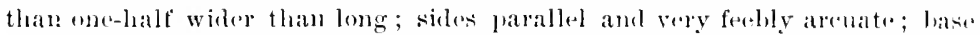

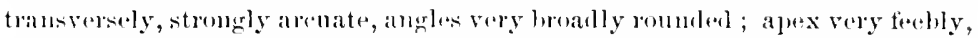
hroadly sinuate, angles not distinetly rombed ; disk very tiebly, evenly com-

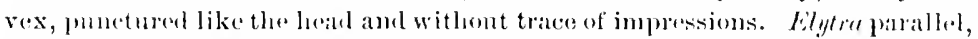
a little wider than long, just visihly wider and one thind longer than the prothorax, depersiol, excessively demsely punetato-gramulose, the semptures

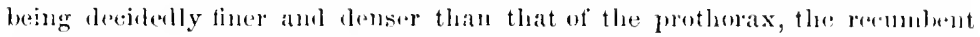
pubescence excessively the and not distinet, the ereet spatsel hairs distinet. dedemen short, fully as wide as the elytra; sides parallel, straght ; border. narrow, moderate in deptla; surface more coatrely punetato-retienlate, the sixth dorsal boadly, feebly sinuate in the midde. Legs rolust. Length 0.9 mm.

Now York (C'oney Island), ('al. I ceconte.

'The paler color, larger, relatively longer prothorax, and decidedly shorter elytra, will serve to sepalate this species from any other of the present section of the genus. The antenne ale just pereeptibly darlice toward tip, and the abdominal punctuation is quite coalder, somewhat dense and very distinet.

'N. grossulus n. sp.--Rather slember, parallel, piceous-black, the auterior portions with a very feeble castaneons tinge; legs and antemuar tlavate; integmments dull. Head linlly as long as wide, very feebly comvex, vary minutely and densely punctate, the pmetures not alsolutely in contart; tubereulations very feelle; eyes molurate, feehly convex, the sinles behind them fielny convergent to the neck; antenne as long ats the liead and pothorax, rather feebly incrassate, second joint fully as lom as the next two, more than twice as long as wide, third distinetly longer than wide, fonth and sixth subecual, very slightly transverse, fifth more rolust, slightly longer

Axrals N. Y. Acad. Scr., V, Dec, 1889.-6 
thin wille, seventh slightly longer and thicker than the eighth, outer joints rather lomger than wile, the eleventh ovoidal, gradually pointed, twice as lonir as wille. Protherer sligletly but distinetly wider than the leatl, one-half wider than long; sides parallel, evenly and rather strongly arenate; base bromlly, more teelly areuate, angles very broally roumber ; a pex very feebly "malrinate, angles not at all lomuded; disk feetly, errnly convex, punetured like the luanl and without distinet trace of imperssions. Elytra quadrate, parallel; sides mearly straight ; disk just perceptibly wider and seareely twofiftlis lonerer than the prothorax, excessively minutely and densely granulese, the recumbent puluscence excesively short, silvery, the erect hairs distinct. Aludomen long and linear, very slightly narower than the elytra; sides straight and parallel; berder numlerate; surface nowe coarsely and sparsely punctatoreticulate; punctures strong; the apex of the sixth segment broally feeluly sinuate in the midhle, with the enge fringerl with a close series of pale porrected menbranous hairs. Legs somewhat slender. Length 1.4 mm..

New York (near the city 1). Mr. W. Jiilieh.

This sperese, the largest of this section of the genus, approaches very near to flacionemis in general form, especially in its comparatively short elytra and bare unimperesed prothorax; it differs in jts much lareres size, in its longer abdominal segments, in color, and in its mueh more consely oramulose and less abbreviated elytra. In flaricomis the elytra together are very distinetly wider than long, while in the present species they are guadrate.

'T. nua cropterus Lec._Trans. Am. Ent. Eve, VI, p. 241.-Rather robust, precous-black throughout the berly, logs and antenne; integuments very dull, the minute reembent pubescence of the anterior portions fulvous, the sparser

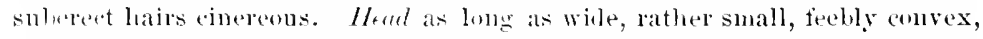
minutely, very densely pum tate. the punctures not completely coalesecent and rather distinctly detindibles :yes ratlecr larese, the tempora not as prominent and less than one-half as long; tuberculations ferble ; anteme distinetly longer than the head and protluor:x, nomlerately robust, distinctly clavate, second joint rather more than twiec ats long as wide and nearly as long as the next two tergether, third nuch liss rohust, elongate, nearly twice als long as wille, fourth very slightly longer than wide, slightly longer and less robust than the sixth, the latter very slightly transverse, fithl more robust, distinctly longer than wide, outer joints rery slightly transterse, eleventh more robust, oroidal, abuptly pointed, one-half longer that wide. Protherex nearly onethirel wider than the head, two-thirts wider than long, almost semieircularly rounderl behind from the midlle of the sides, the middle of the bise less strongly areuate; silles before the midlle slightly convergent ; apex strongly, evenly sinuate throughout the wilth, angles not at all rounded and rery diztinct disk rather more fincly seulptured than the head, gramulose, evenly, fecbly convex, without trace of impressions. Elytra one-third wider and fourfitths longer than the prothorax; sides paraliel and distinctly arcuate; surface 


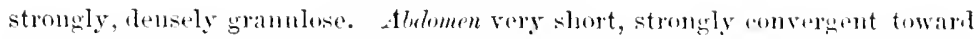
apex, s] ght ly uarower than tho elytra ; borter rather wide and shallow ; sul-

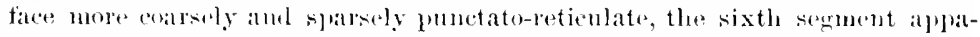
rently with a the enriaceons margin threnghont the wielth. Jength $11.9 \mathrm{~mm}$.

\section{California. C'als. Lecontr.}

A vely distinet species, easily distinguishable from any other of

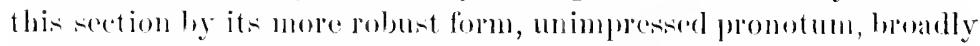
emarginate apex of the protholax, the beal, pothorax and relptra increasing in width in an almost miform ratio, by the distinctly aremate sides of the elytra, the longer, more aherrant antenne, and mally other rharacters. The measurements of length given hy Leconte in his deseriptions of the species of this gents ale decidedly too smiall.

T. somoma n. s1,- Rather skmier, merterately depressed, picens-black

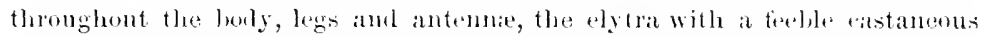

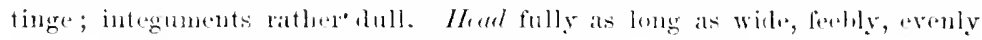

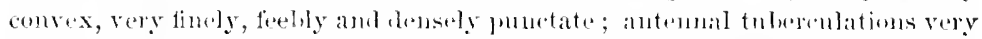

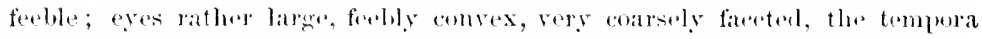

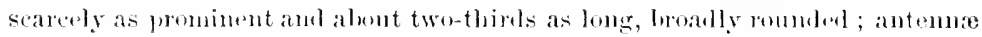
rather robust, distinetly elavate, scarcely longer than the heal and protheras, secomel joint rather more that twiee as lomg as wide and very slightly sherter than the next two combinend, thind distinctly longer than the fondth, the latter fully as long as wide, sherter than the fifth and suberenal to the sixth, eleventh oroilal, peinted, two-thipds longer than wide. Protherer slightly but distinetly

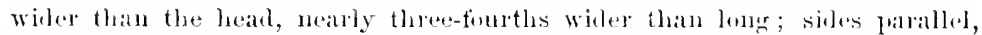

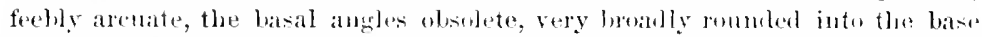

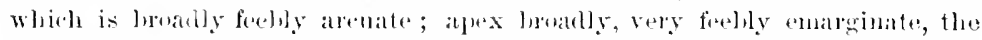

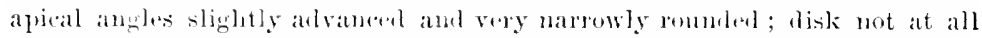

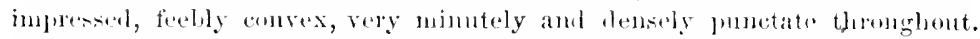

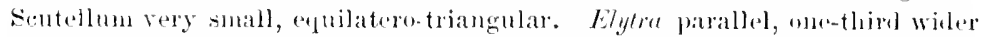
and fontr-fifths longer thatn the prothorax; disk nearly that, strongly imperessed at the sentellum, extremely minutely, densely punctate; puluserece exeessively fine, shert and hense, the longer erect hairs spatsely distrimted over the surtilce. Alutemen very slightly narrower than the elythat, rather short,

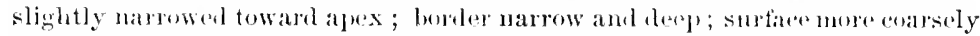
and sparsely punctate, alse coarsely reticulate, ami a little more shininer than the other portions, the sixth serment distinetly shining. Legs rather short and robust. Lengrth $1.2 \mathrm{~mm}$.

C'alifornia (Duncan's Milk, Sonoma ('o. 2).

May be distinguished from py!maxes by its larger size. longer, relatively narrower prothorax, with the apical angles morealramed, and by the entire ahsence of any ristinct pronotal impersions. The punctuation is slightly finer and denser than in that speries. 
T. fimbriatus Lec.-Trans. Am. Eut. Soc., VI, p. 240.-Somewhat rolust, dark piceo-castaneous; antenne same; legs slightly paler; integnments dull. Ilead fully as long as wide, very feebly and evenly convex, very minntely and densely punctate; tulerculations small and feehle; transterse suture fine, arcuate, distinct; eyes morlerate, feebly convex; tempora feelily arenate, ahout as prominent and more than two-thirds as long as the eye; antenne as long as the hear and prothorax, not very rolust, feeluly clavate, secomd joint about twice as long as wide and scarcely as long as the next two together, third slightly longer than wide, fourth and sixth very little wider than long and but slightly smaller than the fifth, onter joints very slightly transverse, the eleventh ovoidal, gradnally pointed, two-thiris longer than wide. Irotherex very slightly wider than the head, five-sixths wicler than long; sides parallel, strongly, evenly arcnate; hase feelly arcnate, angles very broally romded; apex truncate or very feelly sinuate, the angles slightly obtuse and not pereeptilly romnded; disk feebly convex, punctured like the lead, with two feble, distant, hasal impressions. Elytre not widel and four-fifths longer than the prothorax, parallel, depressed, punctured like the prothorax lut rather more finely, the fine dense recumlent hairs so suall as to loe not distinctly visible, the longer erect ones rather sparse and very listinct. Aldomen nearly as wide as the elytra, more coarsely punctato-reticulate; sides nearly parallel and straight; border narrow and deep. Length ( $.7 \mathrm{~mm}$.

\section{Michigan (Detroit 1). Cab. LeConte.}

This species bears considerable resemblance to hesperius, lut may be distinguished by its more robust form, larger, wider prothorax, and relatively shorter elytra. In the type, the abromen is drawn up so as to be very short, and the length given is therefore less than the normal one for the species; the length given by Leconte (0 $5 \mathrm{~mm}$.) is not correct.

T. hesperius n. sp.-Slender, piceo-castaneons; legs and antennap thronghout same; integuments dull amd dense. Heud fully as long as wirle, rather feelly, evenly convex, very densely grannlato-punctate; prominences moderate in size, feelle: eyes large, feelly convex, very coarsely faceted, the tempora not quite as prominent, feebly arcuate and scarcely more than onehalf as long; antemne ecfual in length to the hear and prothorax, moderately rolust, distinctly elavate, second joint oval, twice as long as wide, as long as the next two togetlies, third as wide as long, fourth and sixth equal, smallest, distinctly transverse, fifth subequal to the third, onter joints feethy transverse, eleventh ovoidal, peinted, two-fitths longer than wide. Prothorax very sliglitly willer than the hear, five-sixths wiler than lonit ; sides parallel anteriorly anil distinctly arcuate; base broadly arcuate, coarctate with the sides throngh the rery liroadly rounded hasal angles; apex broaly, feebly areuate; apical angles slightly obtuse, not distinctly romeded disk feehly, evenly convex, punctate like the liead, with two small feeble impressions at the base, trisecting the 
width. Elytra parallel, scarcely one-fifth wiler than the pothorax and fully twice as long; humeri right and very narrowly roumden; surface feelly convex, extremely densely and finely punctisto-granulose, the short apprissed fubescence correspond lingly dense, am the longer erect hairs smowhat dense, very small and not easily sern. Aludmen very slightly narmwer than the elytra and subecpal in length, feelly narrowel toward tip; border moderate in wilth am ileptly; surface feelly convex, more coarsely punctato-reticulate am rather more shining, the pubeseence coarser, as ustual. Length 0.S num.

\section{California (Fort Y mma 3).}

This species may be distiuguished by its slender form, piceonsblack antennie, short prothorax, and long elytra.

T. pygmaeus n. sp.--Rather slemier and depressed, black thronghont ; legs and antemne same; integuments rather dull. IIerd fully as long as wide and distinetly longer than the prothorax, very feebly, evenly convex, very minntely, densely punctate; tuberculations very feeble; transverse epistomal suture very distinct; eyes large, feebly convex, the tempora nearly as prominent, very feebly arcuate and nearly two-thirds as bong as the eye; antenne jnst visibly longer than the hearl and prothorax, feebly elavate, second joint slightly less than twice as long as wide, nearly as long as the next two togetleer, the third very much longer than the fourth which is slightly transverse, subequal to the sixth, the fifth larger and very slightly wider than long, eleventh one-half longer than wile, ovoilal, abruptly pointer. Prothorur slightly wider than the head, very slightly less than twice as wille as long; sides parallel and strongly arenate; hasal angles very loroad!y rounderl, the hase feebly arenate; apex truneate, the apical angles slightly obtuse and scaresly at all rounded, scareely pereeptibly al ranced; disk broally, feebly concex, extremely minutrly am densely punctate thromghont, amb browly strongly inplessed on earh side at the base, the juppressions trisecting the wilth. Elytim slightly wider than the prothorax, aml about twice as long, farallel, very minutely, densely punetate and pubesent, the longer suberect Jairs very short, somewhat dense and not very distinct. Abdomen slightly narower than the elytra, slightly narrowed toward tip, short; borler rather thick, tlat and shallow, the surface transversely convex, more coarsely, sparsely punctate, and slightly shining, especially the sixth segment. Leys moderate. Length $1.0 \mathrm{~mm}$.

Nevala (Reno 1).

The abdomen with its somewhat convex surface, and very shallow and rather wide bordor, contrasts greatly with the same part as seen in somoma, but the structure of this part seens to vary considerably within specific linits, even in the mature state.

The three necies last describer are more elosely allied than usual, and, althongh easily distinguishable in nature by peenliarities of 
form, size and sculpture, are not so satisfactorily differentiated by description.

The following group of three species is res' distinct in the long slender antenne, with all the joints elongate, and nuay be further jelentitied by the abdomen rather strongly narowed from base to "pex, by the large subrectangular prothorax, with the disk perfectly rven and free from impressions, by the slightly sparser, finer punctures, with the surface correspondingly more shining, and ly the decirledly larger size.

T. antemuarius Fanr._-Bull. Sne. Limm. Norm., Ser. 3, Vol. II, p. 97.

I have not hen able to examine this species in nature, and the chancters given in the table were taken from the original description of M. Fanvel.

T. pallidus n. sp.--Rather slemler and fusiform, feelly convex, pale lrown; ablomen picons ; legs and antemne pale flavate; integuments slightly shining. Ilead about as lomg as wide, rapidly narrowed and triangnlar in front of the eyes; sicles in batal half paraltel; surface sublepressed, very minutely punctato-reticulate, finely jubesent; eges molerate, rather conrex, very coarsely ficteted; antemue moch longer than the heal and prothorax, very slender, scarely visibly incrassate, all the joints nucle longer than wide, secom sherter than the next two, fourth and sixth slightly shorter than the thidd and fifth, and very shiglitly more slemler, tenth nearly one-half longer than wille, eloventh slenter, eylindrical, abruptly pointer at apex, nearly three times as long as wille. Prothorar slightly though distinctly wider than the head, alout one-sixtly wider than long; base and apex subegual, very feelly arcuate: silles parallel, feebly arcuate; apical angles narrowly, basal more broally rounderd; disk lirually, feetly wonvex, more strongly so near the margins, even, without trace of inpressions, more strongly shining, sulalutaceous, very minutely and excessively feehly punctate. Elytro abont one-fonth wider and two-tifths longer than the protherax. parallel, subquadrate; sides nearly straight; surface very fecbly convex, alutacens, excessively minntely punctate, the punctures smaller hat stronger than those of the prothorax, not in mutual contact. Aldomen narrowed towarl apex, very slightly narower than the elytra; seconents rather loner borker strong, not rery deep; surface strongly alutacens, reticulate in broken transverse wary lines, the interspaces dull. Length $1.2 \mathrm{~mm}$.

Texas (Austin 2).

The pubescence of the anterior portion is very fine and dense; it is suberect, and is not intermingled with longer hairs as in the precerling section. It belongs near antemnarius of Faurel, but is a much smaller species. 
T. aracilicorn is n. sp.-1holerately slender and fusiform, feetly conrex, black; legs and antennie througlout picents-black ; integuments alutateous. Head small, nearly ats long as wite; sides parallel in betsal half; surtace very firbly convex, tinely, densely punctate; tuberoblations momlerate, rather distinctly elevated; eyes rather large and convex, very coarsely faceted ; sides behind them very short, about one-third as long and obtusely, narmoly roumterd antemne very slender, mud longer than the head and prothorax, extremely feebly incrassate, all the joints louger than wirk, second shorter than the next two, fonrth and fifth subequal, longer than the sixth and shorter than the thim, ninth longer than the tenth, the latter fout shightly longer than wide, eleventh cylindrical, alruptly pointed, two and one-half times as long as wide. Prothorax rather more than one-fomrth wider than the heal, one-sixth wirler than long; hase searcely pereeptibly narewer than the alex, heth feethy arenate; sides nearly parallel, feebly arenate; a pical angles norrowly lut distinctly, basal broally, romeled ; disk evenly ant rather distinctly convex, without trace of impressions, very minutely, feehly punctate; punctures not distinctly definahle. Elytre one-thind willer and nearly one-half longer than the prothorax, quatlate, depressed ; sides parallel and nearly straight; surface extremely minutely, densely punctate and pubsicent. Aldomen gratually narrower from base to apex. slightly narrower than the elytra: segments rather long; border moderate, not very deen'; surfue dull, finely and strungly punctato-reticulate, the reticulations small and slightly transverse. Lengrth $1.5 \mathrm{~mm}$.

\section{California (Sonoma, San Mateo and Santa Clara Cos. 8).}

This species seems to vary slightly in the relative proportion of its parts, but I can peresire no well-defined linits of a suecific nature. It is very distinct from pallidus in its larger size, black color, smaller head, fincr, stronger abdominal seulpture, and sereral other characters.

T. crassicornis n. sp.-Extremely slemd.r, linear, snbelepressed, pale brownish-flavate; leas and antema rery pale flavate; integuments shining, the pubescence noderate in length although somerwhat dense. Ifrad nearly as long as wide, feebly, evenly convex above, rather coarsely and sparsely punctate, the interspates fully twice as wide as the punctures, polisherl, the epristoma on a sliglitly lower plane than the front, the suture short, strongly areuate and rery distinct; tuberenlations small hut rather prominent; eyes molerate; temora parallel, almutly rectangular belime, the head being transversely truncate at hase; antunine fully as long as the liead and prothorax, robust, distinctly incrasisate, the secont joint vory short, searcely onethird longer than wide and sliglitly sherter than the next two together, third transversely oval, fonth and sixth rather wider than the third, very strongly transverse, about expal in wilth to the fifth but rather shorter, the latter nearly twice as wile as long, onter joints very strongly transverse, twiee as wide as long, the elerenth evoilal, pointerl, me-third longer than wille. Prothorar equal in width to the head and very slightly shorter, two-tifthis wider 
than long; sidns parallel, just visibly arcuate; apex and base ecpully and feetly arenate; apical angles very narrowly, basal more broally, rounded; lisk feebly convex, somewhat coarsely and sparsely punctate, with two strong parallel inpressions in the middle, also strongly impressed at the lateral edges in the basal half, and more narrowly so in the anterior half, the edge lwing explanate or very feelly reflexerl. Elylor slightly longer than widn, one-sixth wille and four-fifths longer than the prothorax; silles parallel and straight; disk rather coarsely and sparsely punctate, the punctures separated by from once to twice their own widths, and rather eloser than those of the hatal and prothorax. Aludomen long, linear, slightly narrower than the elytra; sides nearly straight, parallel; borter rather wille, very shallow; surface finely reticulate, finely, not rensely, and subasperately punctate, the punctures not sparser but much tiner than those of the head; apical margin of the sixth segment narrowly free from punctures, smooth and yolished. Legs short. Length $1.1 \mathrm{~mm}$.

Texas (Austin 1).

A remarkably distinet species, decidedly aberrant in the strong and complex impressions of the pronotum, and unusually robust antenne. The punctuation is rery much sparser than in any other species known to me.

T. Validus n. sp.-Clender, dipressed, linear, black throughont; elytra slightly pirous; tilice slightly paler, flaro-piceous; integuments rather shining. Ilemel scareely as long as wide, flattened above, vertex in the mildle just behind the line of antennal insertion more strongly convex; tulesenations rather larere, not very strong; surfaee coarsely, deeply and rather densily punctate; "yes rather suall, feebly convex; tempora parallel, fiobly arenate, as prominent as the eye and nearly as long; antemne slightly longer than the hearl and prothorax, robust, distinctly incrassate, second joint finly as Iong as thr next two, third obeonical, very slightly longer than wide, fourth and sixth smaller, distinetly transverse, fifth larger, very slightly wirler than long, outer juints rather distinetly transverse, eleventh robust, ovoilal, not one-half longer than wide, rather abruptly pointed. Prothorex equal in withth to the hear and histinctly shorter, fully one-half wiler than long; sides feebly convergent from near the apex to the base, and scarcely visibly arenate; apical angles rather broadly rounded; apex rery feebly arcnate; base strongly arcuate throughout the width, the angles obtuse and distinetly ronnded; disk ferbly convex, rather coarsely, deeply and demsely punctate, with two large wirle very feohle longitudinal impressions in the millle, without lateral impressions. Flytra one-third wider than the prothorax, distinetly longer than wile, more than twice as long as the prothorax and sliglitly longer than the head and prothorax together; sisks parallel and almost perfectly straight; disk diphesserl, rather coarsely, deteply and densely punctate, the functures rather smaller than those of the promotmon and separatef by nearly one-halt their own winths. Alelmen rather distinctly narrower than the elytra; sides parallel and straight; bomler narrow, moderate in depth; seg- 
ments mokerate in length; the sixth very much longer than the fifth, with the apex for one-fifth the lenerth perfectly smooth and polisherl ; surface feelly reticulate, very minutely and rather sprarsely punctate, more strongly shining. Length $1.6 \mathrm{~mm}$.

\section{California (Mendocino, Sonoma and Marin Cos. 11).}

The pubescence in this well-marked species is not very dense, and is nomewhat longer than usual. The anterior leg's throughout, together with the coxa, are pale flavate, the posterior piceous, the posterior tibia baving, at the middle of the exterior edge, a long crect seta, which seems to be a constant generic character, but becoming here more than usually pronounced. It is gregarious on the under surface of chips and stones near rumning water, and its motions are extrenely slow, differing greatly from the normal forms, as for instance hesperius, which are never gregarious, and which move much more rapidly over the sand and adobe mut of the river hank. Similar differences of habit are well known in the genus Trogophløus.

\section{PIIALACRIDE.}

With the exception of a fow more or less isolated descriptions, the representatives of this family bave of late years been grotly neglected by systematists. The study of the European species has, however, been recently resumed by Tournier and Flach, and the description of several interesting new gencra by Dr. Shapp in the Biologia Centrali-Americana, has served to revive a still nore general interest. In the following pages I have attempted to perform a corresponding service for the North American species.'

The family seems to be more especially characteristic of the Ameriean, than of the European fauma, for it is here that it reaches its greatest development, not only in the number and rariety of its species, but more noticeably in the unexpected number of distinct and highly specialized generic groups. Altbongh to a superficial view presenting a very monotonous and little variel appearance, I have found the sturly of the Ameriean species a highly interestiug one, the varions genera bring quite abruptly limited, and characterized by an nnusual paucity of intergrading forms.

1 Olibrus piceus Boh., mentioned ly Genm. and Itarold (Cat. ('ol. p. 801) as described from California, cannot be iclentified, and, as the name is perecente pied, should be dropped from onir lists. Phelecrus difformis Lese. (Agass. L. Sup. 222) is an Agathidium. Litocturs hrumi,ennis Mann, is a Choleva. 
In the general classifieation of the gromera I have departed from the original Eriehsonian system, based upon the relative length of the anterjor and posterior tarsi and visibility of the terminal spurs, and have taken as the most important characters in the primary grouping, the structure of the eye and tibial spurs, the mode of antennal insertion, and the size of the seutellum. In the olibri the point of antennal insertion is exposed from above, the large irregular pit or forea in frout of the under part of the eye being very shallow, because of the deep sinuation of the sides of the epistoma. In all the genera of this group there is visible, just above the point of insertion and immediatcly nuder the extreme upler erge of the epistoma, a round flattened chitinous tubercle, aplarently entirely filling a deep fovea this is very constant in all the genera, but its significance cannot he determined.

The variation in the form of the trophi in passing from one genus to another, appears to be of so little inportance in comparison to the sternal and tarsal structure, that but slight use bas been made of these parts, and they have heen totally disregarded in the seheme of arrangement lere proposerl. They are, however, of somewhat grater moment in the Litochrile genera, as will appear below.

In the following table I bare included all the described genera, inclicating those which do not occur within the faumal limits of the Cuited States by an asterisk. The genus Augasmus Mots. is said by 'Tommier to be identical with Phalacrus, and the recently de-cribed Otibrosoma of Tournier, seens to be so aberrant in its fire-jointed antennal elub, that I think it would be better to exclude it from the family as at present organized; it may possibly find a more fitting place in the Silphita. With these exceptions, therefore, the fimily is found to eonsist of three groups of genera which may be defined as follows:-

Eyes of dual structure, the upper portion finely faceted, the lower coarsely so; spurs of posterior tibie strongly dilated.

Antemne exposed at base, the epistoma projecting and trapezoidal ; scntellum small or molerate; elytra striate throughont the wilth.......ToLypur Eyes normal, coarsely faceted thronghout; spurs of posterior tibiæ not at all dilated.

Antenne inserted under the sides of the front, the base entirely concealed

1 Through the grenerosity of Dr. Sharp, I have been able to study all of the Central American genera recognized by this distinguished author, and recently pulbislied in the Biologia Centrali-Americana. 
from above, and the margin of the epistona evenly coaretate; sontellum

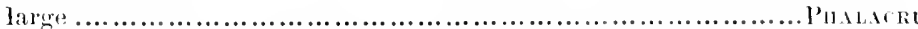

Antenuse inserted at the sides of the front, the base visible from alore, the margin of the epistoma above the point of insertion leeing more or less sinuate; seutellnu small or molerate

(1) Ellilit

The genera composing the groups may he defined as follow: -

TOLYilli.

Sides of the prothorax not coarctate with those of the elytra....*Tolyphus

Phatacrt.

Spurs of posterior tibia very short, not projecting beyond the terminal fringe of spinules; elytra with a discal stria

Plualaceus

Spurs of posterior tibie long and distinct; elytra entirely devoid of strie.

Plhalacropsis

Olibri.

Basal joint of the posterior tarsi shorter than the second.

Apex of the prosternal process inflexed, withont an acute and free enge, and deroid of spinose sete; metasternal process greatly developed, the mesosternum before it reeluced to a fine bead.

Elytra with one or two discal strie, the suture beaterl; second joint of the posterior tarsi molerate in length, free

olibrus

Elytra with a single discal stria, the suture not haded; second joint of the posterior tarsi molerate in length, rigidy articulated with the hasal joint

Olibroporus

Elytra entirely devoid of discal strix ; second joint of the posterior tarsi greatly elongate, subanchylosed to the first.

Euditrus

Apex of the prosternal process with an acote free edge bearing a transverse series of spinose setre; mesosternum more developed in front of the metasternal process ; elytra constantly with a single discal stria, the suture not beaded.

Mesosternum not prolonged hehind the middle acetalula; second joint of the posterior tarsi very long, subanchylosed to the first.

Litolibrus

Mesosternum prolonged and sometimes greatly developed behind tho middle acetabula.

Second joint of the posterior tarsi very long, spougy-pubescent leneath in the male, the articnlation with the first joint rigrid; postrior tibial spurs long, very unequal; sexual liflerences in the postrior tibie, terminal spurs and tarsi strongly marked

Acyloums

Second joint moderate in length, anchylosed rigilly to the basal joint, elothed througliont with small sulnecumbent spinose seter tihial spurs molerate

\#ioplualaceus

Second joint molerate in length, finely pulwsent beneath in both sexes; articulation with the hasal joint thee; tibial spurs small and inconspicuons; sexual differences in the posterior legs not olserva- 
1)le, the male sexual characters, when visible, affecting the abrominal segments only Stilbus Basal foint of the posterior tarsi longer than the second; elytra with two discal strice.

Prosternal process intlexed at apex, devoid of terminal setre.

Basal joint of the posterior tarsi extremely elongate, much longer than the entire remainder; mesosternum not extending behind the midcle acetaluta exeept as a tine marginal bead; sexual differences in the posterior leges not observable.

Litochrus

Basal joint elongate but distinctly shorter than the remaining joints combined; mesosternum extemling behind the middle acetabnla, where it is moderately developed; sexual differences in the posterior legs conspicuous.

Prostermal process not intlexed, having a free acnte edge.

Litochropus Ochrolitus

TOLIPIIUS wichs.

The anteme in this genus are unusually short and robust, the two hasal joints of the club strongly transverse. The prosternal proeess is rather wide, gradually inflexed at apex, and margined throughout the sides and apex with a fine strong convex bearl it is not in the least setose, and, in repose, rests against the rertical portion of the mesosternum. The metastermal process is rather narrower than in Phalaclus, but similar in form and extent, the mesosternum forming a fine apical and lateral bead. The mesosternum behinel the middle acetabula forms a fine bead as in Phalacrus.

The torminal spurs of the posterior tibia are short, although projecting well beyond the terminal fringe of spinules; they are rery strongly dilated toward base and pointed at apex.

The singular strueture of the eyes mentioned in the table, together with the structure of the tibial spurs, isolates Tolyphus widely from the rutire remainder of the family, and constitutes of it a group equiralent to either the Phalacri or Olibri. The first of these characters, neither of which has apparently been before noticed, is of excodingly rare occurrence in the Coleoptera; the second is often seen as a moditication of the anterior spurs in the Harpalini.

The observations above noted were made upon $T$. yramulatus Guér. from Spain. No species has yet occurred outside of the Mediterranean province of the palaearctic fauna. 


\section{PHALACRUS Payk.}

The general eharacters distinguishing this genus from the others are fully laid down in systematie works, and are stated in a les extended form in the preceding table.

The speeies do not appear to be very numerous, and among the sixty-seren specimens before me, I am unable to distinguish more than eight, which is considerably less than the eighteen descriled by Tournier (L'Ent. Gen. 1889, pp. 7-10), as helonging to the European fama. The species are more closely allied and indefinite than in any other genus of the family. I have not noticed any distinet sexual modification in the male; the middle of the anterior margin of the epistoma is, howerer, in some forms broadly arenate and coarctate with the sides and in others more or less truncate, and these differences are said by both Tournier and Flach to be sexual in origin. I have not attempted to verify this, and have simply mentioned the form of the apical margin when noticed during description.

The punctures of the head mentioned by Tournier, are present in all our species, but 1 have not been able to employ them in separating or characterizing the species, as they appear to vary in relative position in different individuals. These little forea to the number of four, are situated along the inner margin of the eye, and there is also another near the anterior margin of the epistoma, and remote from the eye; they are not setigerous as far as can be observed with the highest working powers.

The sculpture of the elytra is moderately constant, but the impressed lines lying parallel to and near, but not inchung the series of punctures, are more or less variable in distinctness, and do not seem to form a specific character of very great importance.

On each elytron in some if not all the species there are certain short stiff and erect seta, which do not appear to have been previously noticed, and which in simplex are disposed as follows:-

$\Lambda$ row of very closely-placed excessively minute seta along the under surface of the acute lateral cdge, projecting downward.

A row of more distant, longer and coarser seta, very close to the minute bead forming the lateral edge, or just within its outer limit.

Finally, on the disk of each elytron, five rows of excessively minute stiff setæ which are extremely widely spaced, and more evident toward apex. The fifth row from the suture contains six 
or seven seta and extends nearly to the base, the fourth row four setar, extending to about one-fourth the length from the base, the third row about three seta, extending slightly beyond the middle, the second row two, extending nearly to the middle, the first row being hetween the sutural and diseal strie and containing two to forll setae.

The setae are more widely spaced in the rows toward the suture, exerpt in the first row where they loceme slightly less distant. The setigerous punctures may or may not eoineide with the punctures of the series, and do not differ greatly from them in form, being morely a litte nore promonned. In some species they are not visihle at all, but as far as I have beesu able to olserve the marginal line of larger, more closely placed sctae never beeomes ohsolete. These ale entircly distinct from the excessively minute fine recumbent hairs, horne by the ordinary punctures, and no doubt serve efuite a different purpose.

In the folluwing tahle only those charactel's are employed which aplear to be of decided impurtance; they relate to the sternal, tarsal and antennal structure, and clytral sculpture, and weight shouhd ferhaps be assigned to them in the order named :-

Metasternal process not extending beyoud the middle coxae, truncate at apex.

ovalis

Metasternal precess projecting beyond the middle cose, more or less strongly rommied at apex.

Third antemal joint equal in length to the two following united.

lilytra enticely polished, or with but slight trace of reticulation toward a

Punctures of series very fine, not becoming decidedly coarser at the sintes.

Form robust, suboblong; size largte..................penicillatus

Form less rolust, evenly elliptieal; smaller in size...............say $\mathbf{s}$

lunctures of series very fine, becoming abruptly much larger and

foroully lunate at the sides; form narowly oval and slightly narrowerl behind

simplex

Elytra tinely and more or less feebly reticulate over the entire surface.

lunctures of elytral series extremely feeble and rather indistinet.

Auteminte pale; sternal processes very wide, the metasternal scarcely more than twice as wide as the prostermal; form very broally oval

Antemne black; metastermal process narrower, more strongly rombed at apex and about three times as wille as the prostermal; form more narrowly oral; reticulation of npper surface much more feeble.

conjunctus 
Punctures of series very strong, the series equal, approximate and very distinet, extending almost to the base...................seriatus

Third joint of antenne distinctly shorter than the two following united; upper surface finely, feebly reticulate....

pumailio

P. ovalis Lec.-Pro: Ac. Phil., 1856, p. 15.-Evenly elliptical, on1--half longer than wide, intense black thronghout; legs, trophi and antemne same;

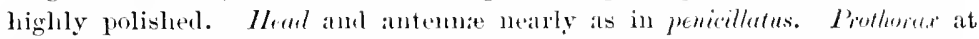
base twice as wide as the luarl, a little more than twice as wide as long, very minutely, feebly ant rather spatroly punctate, otherwise as in penicilletus. Seutellum large, two-thirds wider than long; triangular; sides arcuate; a pex narrowly rounded; surfice very minutely and almost imperceptibly punctate. Elytire two and one-half times as long as the prothorax, gralually, evenly, semi-cireularly ronuded behiml, polished but having very indistinct traces of eoarse reticulation toward apex, punetured in approximate rows of small rather closely-placed romuled and distinet punctures, which become nearly obsolete toward base, the alternate rows loing decidedly more dintinct and even, the intermediate rows composed of much smalter and feebler prumctures, quite unevenly arranged : sutural beal fine and chistinct, the stria continuous along the seutellum and with the hasal stria; discal stria strong, vanishing at from one-fifth to one-sixth the length from the hase. Ahdomen clothed ratluris densely in the mildle, and very span'sely toward the sides: with couldse latirs. Legs robust; posterior tarsi slender, two-thirts as long as the tilia, with the tirst joint searcely one-half as long as the secoml. Lemgth $1.8-2.5 \mathrm{~mm}$.

\section{California (Sonoma aud Monterey Cos.).}

The metasternum projerts betwen the mirlde coxa to the anterior limit of the latter' it is broad and subtruncate at apex, between three and fom times as wicle as the narrowest part of the prosternal process, and the mesesternum forms a fine bearl in the midnle portions of the apex. which becomes much more evident at the sides.

The specjes resembles penicillatus very closely in sculptur and coloration, hut is smaller, the largest specimens being equal ju size to the smallest of that spereirs; its form is more narowly aud evenly elliptical, and the structure of the meso-intercoxal parts quite different. In penicillutus the metasternal process extending leyond the anterior limit of the undule coxe, the mesostelnum is excarated under the overreaching visible portions, while in the present speeies the mesosternum, axeepting the portion forming the very fine terminal bead of the metasternum, forms a very fecbly concave perpendicular surface.

P. penicillatus Say.-Journ. Ac. Plil., IV, p. 91.-Robust, somewhat oblong; sides feetly arcuate ju the midnle, subtruncate behind ; highly polished, intense black throughout the body, legs, trophi and antemne, the 
latter sometimes slightly piceous. Ifeud twice as wille as long, feebly, evenly convex; "yes moderate, their surface perfectly contimons in couvexity with the front, and their lateral margin coarctate with the anterior margin of the hear, the latter perfectly evenly arenate throughout in circular segment; surface fioly and somewhat sparsely punctate; antemne molerate, funicle very slemker, thiml joint as long as the next two, club as long as the five precerling juints combinest, the last joint one-third longer than the ninth and tenth contbined. Prothorax twice as wide as the head, and two and one-half times as wilde as long; base transverse, very feehly broally sinuate at each side of the scutellum; luad very feeble and entirely obsolete in lateral third ; silles evenly arenate; disk very finely and rather sparsely punctate. Scutellum large, nearly twice as wide as long; sides feebly arcuate; apex narrowly rounded; surface very finely, feebly punctate except toward the margins. Elytra abont throe times as loug as the prothorax, abruptly rounded behind ; sutural stria very finc, forming a narrow sutural bead, continuons along the seutellum with the transverse hasal stria, the single discal stria fine but distinct, joining the sutural at the apex, and becoming olsolete at one-fifth the length from the hase; disk highly polished, without reticulation, having equidistant approximate rows of fine rounded feeble punctures, the alternate rows being slightly bettre defind, the punctures becoming olsolete toward base, and scarcely pereeptiliy larger near the sides and apex. Aludmen elothed rather sparsely with stifl semi-rect hairs. Legs robnst; middle and himd femora with a row of stifl hairs along the posterior lower elge, which lecome longer near the a pex; anterior tenora without trace of such hairs, posterior clothed on the lower surface with coarse yellowish har ; teminal spinuls of posterior tibie short, even, concealing the spurs, the corresponling tarsi short, with the first joint about one-half as long as the second. Length $2.3-3.0 \mathrm{~mm}$.

\section{Southern California; Arizona; New Mexico.}

In the type, which is one of the larger specimens from Sontheru California, the metasternal process projects well beyond the middle coxe, the apex being broadly arcuate or subtruncate, the mesosternum forming a thickened and very strong apical bead; the width of the portion between the middle coxe is three times as great as the narrowest part of the prosternal process; the latter is impressect. In other specimens the metasternal process is nearly four times as wide as the prosternal, more strongly areuate, and more fincly beaded at apex.

P. Sayi n. sp.-Evenly elliptical, convex, highly polished, about one-half longer than wille, intense black throughout above and beneath, the antennie just vi-ibly picenus toward base. Hend very minutely, rather sparsely punetate; ryes small; antenne moderate, third joint as long as the next two together, club very slender, the eleventh joint distinetly longer than the two precedint together. Prothorax very minntely sparsely and feebly punctate, extremely broadly feebly lobed at base; beaded margin evident in the middle. 
Seutellum triangular, one-half wider than long; sides feebly aronate. Elyfrn having series of minute, feeble and rather distant punctures, which arr lut slightly more distinct and but slightly eloser at the sieles, not in the least resticulate; diseal stria tine and distinct, obsolete at hasal fourtl. I'usterior tarsi very slender, the third joint elongate, not dilated and not wiler than thesecom. Jengtl $1.7 \mathrm{~mm}$.

\section{Arizona (Coolidge).}

The metasternal process, as usual, projects beyond the coxie and is strongly rounder at apex, with a fine apical bead; it is about three times as wide as the prosternal process, the latter moderate in width.

This snecies very greatly resembles simplex, but diffors in its finer, feehler, sparser and less dilated punetures at the sides of the dytra, in its still more slender po-terior tarsi, and in its decidedly -maller size. It is represented by two specimens, collected by Mr H. F. Wickham.

P. simplex Lec.-Proc. Ac. Phil., 1856, 1. 16.-Ovoidal, more pointed lelind, black; legs and antennce picro-testaceons; npler surfice lighly polished. Heal feebly subtrumeale in the middle at ajex, feebly eomrex, very minutely feelly and suarsely punctate: antenne rather short, the club almut as long as the six preceding joints together, not very rolust, the eleventh joint me-half willer than the nimh and nearly one-halt longer than the two preseding together. Prothorar sliglitly more than twice as wide as long, two-thirds wider at base than at apex; lasal head ahnost completely obsolete; disk very minutely, sparsely and feebly junctate. Scotellum large, two-thimls wiler than long, triangular, the siles very ferbly arenate, and the ajex just risilly rounded, the surface extremely finely sparsely and obsoletely punctate. Lytro about two and one-third times as long as the prothorax, gradually narrowed behind and acutely ronnded at alex, the sutural stria very fine and as usual contimums along the seutellum, the discal stria fine but distinet, teminating at one-fifth the length from the hase; disk polished, not at all reticulate or subgranulose, except very obsoletely so near the apex, and in the very vaguely impressed strix adjacent to the ill-defined rows of punctures, the latter very tine and feeble extept near the sides and apex, where they becone almuptly unusually large, strong and brodally lunate; the vaguely defined improssed lines are, however, more or less definable nearly to the base. Abdomen covered sparsely with very conrse hairs, denser toward the midlle. Legs molerate; posterior tarsi slender, nearly three-fourths as long at the tibia, the basal joint not quite one-half as long as the second. Length $1.9-2.5 \mathrm{~mm}$.

\section{New Mlexico; Texas; Iowa.}

The metasternal process is broad, distinctly prolonged beyond the middle eoxe, broadly and distinctly rounded and subtruncate in the middle at apex, with the mesosternal bead rather fine. The vague impressed lines of the elytra, which are distinctly visible in some

Annals N. Y. ACad. Scl., V, Feb. 1890.-7 
specimens of which the original type is one, occasionally entirely disappear.

There are hefore ne two specimens collected at Luna, New Mexico, hy Mr. Wickham, which appear to belong to this species; they are nearly as small as Sayi, and notably smaller than any other specimens of simplex which I bave seen. I prefer to attach them provisionally to simplex, hecause the punetures at the sides of the elytra are widc and deeply inpreseded, as in that species, but they are not included in the above measurement of length.

P. Dolitus Melsh.-Proc. Ac. Phil., II, p. 102.-Breadly oval, from onethird to two-fifths longer than wide, black above and leneath; legs and antemme paler, dark rufo-testaceous; molerately shining. IHerd feelly snbtruncate at apex, very minutely, feebly reticnlate in lroken wavy lines, finely, rather sprarsly and distinetly punctate; antenne rather slender, club much shorter than the six preceding joints combined, the last joint about one-third longer than the two precerling together. Prothorat twice as wide at base as at apex, and slishtly more than twice as wide as long, the basal bead tine and distinct in mindale third; disk excesively minntely and fethly retienlate in wavy lines, extremely minntely, feebly and rather sparsely punctate. Scutellun acntely ogival, one-half wider than long. Elyfra abont twiee as long as the prothorax, not narrowed toward apex which is very broadly, evenly rom ted : sutnal stria continuous, very fine; discal fine, distinct, terminating at hasal sixth; aink withent distinct impressed lines, having approximate and nearly equal rows of fine feeble punctures, which do not become entirely olsolete at base, and rather abruptly much larger, stronger, partly confused and broadly lmate at the sides and alex; surface finely and distinctly retienlate, the reticulations extremely minute, and forming imperfectly defined transverse wavy rows toward hase, eoarse and more robinded towarl sides and apex. Abromen tinely reticulate, ratler coarsely, subasperately punctati, coarsely pubescent. Tarsi molerately slender, with musually coarse and prominent tufts of yellowish hair beneath, the posterior two-thirds as long as the tibia, with the first joint scarcely one-half as long as the second. Length $1.5-2.2 \mathrm{~mm}$.

Pennsylvania; North Carolina; Missouri; Texas.

The metasternal process projects far in advance of the middle coxie, and is strongly rounded at apex, the apical bead rather fine and not at all dilated laterally, the prosternal process unusually wide, being at its narrowest part but slightly less than one-half as wide as the metasternal.

This species is very common and widely diffused; it does not appeur to vary much except, as usual in this genus, in point of size. It is the least shining of any of our species except pumilio. 
P. conjunctus n. sp.--Evenly elliptical, one-lalf longer than wide, black; legs and antemne ficoms-lidack; strongly shining. Hecel twice as wide as long, finely, rather sparsely hut distinetly punctate; anterior margin subtruncate in the mildle; antenne rather rohust, last joint of club moderately densidy and rather eoarsely pubucent, but slightly longer than the two preceding togrether. Prothorux rather distinetly more than twice as wide as long; hase three-fourths wister than the apex, the former transverse, wery feelly simnate at each side of the sentellum; hasal bead rery fephy defined in the michlle, whollete laterally ; disk very minutely sparscly and indistinctly punetate. Scutellum the es-fourths wieler than long, ogival, very mimutely, feebly prunctate except towarl the edges. Elytra alont two and one-half times as long as the prothorax, gralually, evenly and not olotusely rounded behind; sutural strie very fine, entire, very closely burlering the scutellum; discal five but distinct, vanishing at one-fifth the length fron the base: disk very finely but distinctly reticulate throughont, puncturet in approxinate rows of small distinct feebly inpressed punctures, the alternate rews not applarently more well marked or even, the punctures being sensilly dilated and crescentiform, each with the usual ninute recumbent hair, the retienlations and punctures stronger toward apex and the sides, and almost obsolete near the hase. Abdomen sparsely clothed with conrse hair. Legs moderately robust : terminal spurs of pesterior tibie suall, short lint distinct and not concealed hy the even and closely-plated row of terminal spinules; corresponding tarsi rather slemiler, nearly three-fourths as long as the tibia, the lasal joint two-thirds as long as the second. Lemgth 1.8-2.3 mm.

\section{California (San Diego); Arizona.}

The metastermal process is of the nsual wirth ; it projects slightly beyond the middle coxe, and is strongly rounded at the apex, the apical bead very fine and not much dilated laterally.

This species is not very elosely related to any other, resembling penirillatus in sternal structure, but differing greatly in size, shape and seupture.

P. seriatus Lec.-Proc. Ac. Phil., 1856, p. 15.-Broally, evenly elliptical, less than one-lialf longer than wide, hlack; antemme black; legs piceonsblack, the tarsi dark piceo-testaceous; upper surface polishet. Hect finely but distinctly punctate, feehly subtruncate in the middle at apex ; antenuse moderate, chub rather robust, the last joint distinctly longer than the two precerling together. Prothorax fully twice as wide at hase as at apex, and nearly two and one-half times as wide as long, the basal bead extremely fine and feelle; disk minutely and sparsely, but rather distinctly punctate, the surface not visibly reticulate. Scutellum nearly twice as wille as long, ngival : sides distinctly arcuate; surface very minutely punctate. Elytro nearly two and one-halt times as long as the prothorax, very lmadly, evenly rounded behind, the sutural and discal striee as usual, the surface excessively finely, feebly and indistinctly reticulate, more visibly so llear sides and apex; disk 
with approximate and equal rows of very distinct punetures, which do not hecome larger at the sides, and which disappear only within a very short distance of the base. Abdomen reticulate in wavy lines, especially near the sides, coarsely pulessent. Legs robust, posterior tarsi somewhat robust, very densely, coarsely pubescent beneath, about one-third as long as the tibia. Length $2.0 \mathrm{~mm}$.

Kansas-Dr. LeConte; Colorado-Mr. Schwarz.

The description is taken from one of the Colorido speeimens, as the original type cannot be found.

The metasterual process is rather narrower than usual, projects far beyond the midlle roxie, and is strongly romded thrombout at apex; it is scarcely three tines as wicle as the narlowest part of the prosternal poross, and the apital bead is rather fine and not dilated Iaterally. It is a very distinct speries in its strongly marked, apmoximate, eyeal rows of elytral punetures. The type exhibits no trace of impresied ejytral lines.

P. Domilio Lec.-l'roe. Ac. Phil., 1856, p. 16.-Evenly, rather broadly oval, warcely ont-half longer than wirle, llack above, piceous beneath; legs and antenure pale yellowish-testacens, rather strongly shining. Head as usual; antenne rather robust, the eluh moderate, the eleventh joint but slightly longer than the two jereceding combined, the third joint notably shorter than the fourth and fifth together. Prothorar vely nearly as in politus. Sutellum ogival, nearly two-thirds wiler than long. Elytra a little more than twice as lomer as the protholix, not at all narowed toward apex, hroadly, evenly rombed behind, with reticulation and discal strie bearly as in politus: having aploximate and mearly equal rows of rather small and distant, and extremely feeble punctures which are, at the sicles, much larger, more confused and broadly lunate: surtace with very fine vague impressed lines, which are continnous nearly to the base. Legs moderately robust, short. Length $1.4 \mathrm{~mm}$.

\section{Middle Atlantic States.}

The condition of the type, which is the only speeimen which I have sren, prevents a description of the abdomen and posterior tarsi. The metasternal process is very wide, and projects far beyond the middle coxie, the apex strongly rounded, the apical bead very strong and rather flat, not dilated laterally.

Pumilio greatly resembles a very small specimen of politus, almost exactly so in seulpture; it is, however, very distinct in several important points of structure, and notably in the antenme, in which the third joint in politus is fully as long as the next two together, also in sterual structure, the prosternal process here being 
much narrower and not over a third as wide as the netanternal. The punctures of the elytral series are, on the mpere parts of the disk, rather more distant and decidedly more fectle than in polites. It appears to be very rare.

PIIA LA CIROMEIS n. gen.

Mentum trapezoidal, truncate at apex. Maxillary palpi with the last joint slender, subcylindrical, nimutely truncate at ajex, slightly narrower than the third, ant nearly twice as long. Antemne slender ; third joint as long as the next two together; club slender, the nintli joint fully as wide as the tenth and slightly longer, eleventh narrower, elongate-oval, and slightly shorter than the two preceding. Prosternal process moderate in width, very feelily concave, inflexed, not ciliate at apex; metasternal process broul, fully three times as wirle as the prosternal, projecting to the anterior limits of the coxal cavities, where it is transversely truncate, the truncation very feebly arcuate, the apical brad rery fine in the midrle, thiekened at the lateral angles, and again fine along the coxal cavities. Legs short and very robust; spurs of the posterior tibise stenter, equal, nearly parallel, projecting distinctly beyond the spinose fimbria; the corresponding tarsi but very slightly longer than the anterior, nearly as in Phalacrus, with the basal joint less than one-half as long as the second. Pronotum without trace of hasal lwarl in the middle. Scutellum large. Elytra not at all striate, having a very fine sutural bead, the fine stria being continuous with the basal stria along, and alnost tonching, the scutellum; discal stria entirely obsolete.

The single species forming the type of Thalacropsis, is quite peculiar in form, being decidedly more elongate-oral and just perceptibly more depressed than in the varions forms of Phalacrus. Although remote, it is the nearest ally of Tolyphus in our fauna.

P. dispar Lee.-Bull. U. S. Geol. Survey, V, No. 3, p. 513.-Castaneons, ovenly elongate-elliptical, tully three-fourths longer than wide, convex, polishenl. Head rather small, evenly remuled at apex throughout its width, very minutely sparsely and olsoletely punctate. Prothorex at base more than twice as wide as the head, jolished, withont trace of reticulation, very minutely, rather slarsely but distinctly punctate; base transverse, feebly sinuate at each side of the scutellum. Scutellum large, abont twice ats wide as long, ogival, very obsoletely finely and sparsely punctate. Elytre nearly three times as long as the protherax, not narrowed behind, broally, evenly rounded at apex, polished but having very indistinct traces of minute way reticulation, which beremes more evillnt and confused near the sides and alex; punctures lunate, arranged in rather pooly-defind distant series, the intervals with mere confused punctures which are nearly erfual to them in size, rather large but feeble, much larger, denser and more contused at the sides, where they are very broally crescentic. Legs and under surface pale testaceous, sparsely, coarsely pubescent. Length $3.0 \mathrm{~mm}$. 
Colorado (Teta Pass). Mr. Schwarz.

I have only seen one sperimen of this remarkable species.

\section{OLIHIRUs Erichs.}

The genus Olibrus differs from Phalaerus in only two very inportant particulars, but in a large number of eharacters which must he considered of more or loss subsidiary value. The two most marked differenees are found in the mode of antemal insertion, and in the size of the sentellum. In l'halacrus and its allies with large sentellum, the antenne are inserted far under the epistoma in very deeply excavated cavities in front of the eyes, the anterior margin of the head being arenate continuonsly with the eve throughout the width, while in the genera with small scutellum, the epistomal edge is deeply simnate laterally, and the points of antermal insertion more visible from above. In the structure of the sterna the two genera are ilentical. The posterior tarsi and tibial spors are, howrver, slightly longer than in Phaberus, hut I eamot regard this as of such derisive importance as the two characters mentioned. The small forre near the eyes, visible in the genera with laresentellum, are gemerally ohsolete in the others. From Stilbus this genus differs much mole radially than it does from Phalacrus, in the very important structure of the mesosternum behind the middle coxa.

In two characters Olibrus stands almost alone in the family, the one relating to the form of the teminal joint of the antenne, the very strongly constrieted terminal process so perfectly developed here heing merely indicated in Phalacrus, and aluost entirely obsolete in Stilhus, the other relating to the punctures of the elytral scries, which are never transversely erescentiform, but if modified at all from fine simple points, distinctly attenuate posteriorly ; this form of elytral punctuation I have not found to exist elsewhere, except in Olibroporus. It is true there are many speeies of Stibus which are perfectly devoid of the peeuliar crescentiform pumetures, but in this case the punctures simply disappear and never assume the elongate form here alluded to.

In the absonce of the terminal line of robust setiform spinules at

1 There is an undescribed Sonth African species before me, in which the punctures at the sires become slightly dilated, but although it is apparently assignable to Olibrus, I am not entirely certain that it really belongs to that genus. 
the apex of the prosternal process, Olibrus again resembles Phalacrus and differs correspondingly from stilhus. In fact the resemblances of Olibrus to the latter genus must be regarded as in great part superficial.

Our species are very much less numerous than those of the European fauna, but the very linited nmmber which we possust are more heterogeneous, and this opinion is strengthened by the characters assigned to the Central American forms by Dr. Sharp. Our species are in fact divisible into two groups of subgeneric impoltance, only one of which appears to be pepresented in the Emropean fauna.

I.

Elytra with two discal strice.

Elytra maculate, vittate or differing in color from the pronotum.

Black, elytra with two oval rufous spots near the apex........... LeContei

Elytra paler, castaneous, each with a broal ill-clefined flavate vitta; pothorax concolorous

vittatus

Elytra pale, a suffused lateral, and a more distinct sutural, vitta blackish ; liear anl pronotum jiceous-black.

nigricollis

Elytra unicolorons.

Elytra without impressed lines accompanying the series of punctures; surface withont trace of reticulation, perfectly polished throughout.

Elytra with very finely, feelly impressed lines.

pallipes

linpressed lines stronger and mole evillent; elytra polished, finely granulato-reticulate only at the immediate apex semistriatus Impressed lines very feeble; elytral reticulation finer, more longitudinally aciculate, present at the sides and toward apex.

Fonn evenly elliptical, more convex, not attenuate behind; impressed limes almost olwolete

neglectus

Form more narowly oval, attenuate behind, less convex; impressed lines fine but somewhat distinct.

rutipes

II.

Elytra with a single discal stria. ${ }^{1}$

Narrow, densely acicnlato-reticnlate. Wickhami

D. LeContei n. sl.-Ratler loroaly oval, just pereeptibly attenuate behind the middle, strongly convex, highly lolished, black above, with a rery clearly-definch elongate-oval spot of hright rufu-testaceous from the midcle of each elytron nearly to the apex, aplroaching but not attaining the suture;

1 Olilirus bisignatus Boh., of the Cape of frool Hope, also belongs in this groul ; it almost perfectly resembles Le Contei in form and coloration, but is very lensely reticulato-granulose throughout. 
under surface, legs and antemmx pale rufo-testaceous. Head extremely finely and tewhly punctate; antenuse molerately slender, third joint about as long as the next two together, club nearly as long as the six precteding joints combiner, rather compract, nearly symmetrical, the weventh joint as long as the two precerling together. Prothorex of the usual form, more than twice as wirle as long, feebly lobed in the midnle at base; hasal bear apparently entiroly ohsolete; sulface very minutely, sparsely and extremely feelly punctate. sentellum ugival, one-half wider than long. Elytre about two and one-half times as long as the prothorax, very strongly roumlet at apex, highly pulished, withont reticulation exont the ferblest possible trace at the immediate apex, the sutural bead continuons nearly to the base, very fine; two discal stria distinet, nesply equal in length, vanishing at between one-third and one-fonth the length from the hase, the first coincident with the sutures at the extrene ap+x, the seome approaching but not miting with the first at posterior fourth or fifth; disk with rows of excessirely fine feeble pmnctures, which become sliglitly mone distinct at the sides, the series not accompanied by impuessed lines. Aldomen minutely reticulate, coarsely pubescent. Legs molerate; posterior tiliae slender, subylindrical toward apex; spurs distinet, the tarsi slemder, fully three-fomrths as long as the tilix, with the first joint less than one-half as long as the second. Length $2.3 \mathrm{~mm}$.

\section{Atlantic States.}

The metasternum is polished, not retieulate and not pereeptibly punctate, the process rather short, strongly rounderl at apex, the meso-ternum widely visible at the sides of the apex, but reduced to a fine acntely elevated bead in the midnle.

This species bas heretofore been considered identical with the Eurouran licolor, but specimens of the latter sent me by Reitter and confirmed as to their identity by the tables of Flach, show conchusely that it is very distinet. In the true bicolor, the elytra are reticulate at least as far as the middle, the metastemum in coarsely and decely punctate, the form is much more elongate, the size is lareer and the elytral spots nore diffused. LeContei seems to coincidr mueh more elocely with the lepidus of M. Tonrnier's recently published table (LEnt. Gen. I, p. 89), but is probubly distinct, as the European species of this group seem to be uniformly more slender and attenuate behind, and have a large part of the elytra distinctly reticulate.

O. vittatus Lec.-Trans. An. Ent. Soe, 1868, p. 50.-Evenly elliptical, or very fiebly attemuate behind, about two-thirds longer than wille, strongly convex, highly polished, pale castameons above, each elytron with a broal, very liffused median vitta of paler flavo-testaceous, more distinct tuwald base and not quite attaining the apex; moler surface, legs and antenne pale thavo- 
testaceons. Head excessively finely, feebly and rather sparsty punctate; antemme moderate, third joint not quite as long as the next two, chub ruhust, compact, very strongly compressed, ninth joint slightly wider than long, ninth amd tenth slightly more theveloped on the anterior sicle, nine to eleren increasing gradually in wilth, the latter fully as long as the two preceding, with the apical process well developed. Prothorax feebly lober in the mirlle of the hase; hasal beal distinct in the mirlule; surface extremely sparsely minntely and feebly punctate. Seutellum wiler than long, ogival. Elytra nearly thres times as leng as the prothorax; sutural bead very tine, disalyearing at basal third ; discal strix fune but distinct, almost exactly as in LeContei; surface not reticulate, having rows of very fine punctures accompanied by the feellest trace of fine impressed lines; alternate series more distinct, the intermediate series of finer punctures almost completoly obsolete towari suture. Aludomen minutaly and rather strongly reticulate am alntaceous except as usual along the apices of the segments, where it is polished, coarsely and rather sparsely phlescent, and suluasuerately punctate. Legs nearly as in LeContei. Length 2.2 mm.

\section{New York.}

The metasternmm is polished, not perceptibly punctate, the few sparie hairs entirely filling the punctures, the process is broader than usual, broadly, evenly rounded at apex, projecting but slightly beyond the middle coxa, the mesosternum being reduced to a very finc apieal bead which is only slightly wider at the extreme sides of the apex

The vitte of the elytra are extremely diffused, and in sonu lights become almost invisille; the punctures of the elytra are rather more distinct than in LeContei, and the form is slightly more elongate-oval and less attenuate bebind than in that species.

O. nigricollis Lec.-Trans. Am. Ent. Soe, 1868 , p. 50.-Evenly, rather broally elliptical, strongly conver, polished; head and pronotum blackishpiceons; elytra rufo-testacenus, the lateral margins narrowly, more feebly and indefinitely, and a broad, more definite and darker sutural, vitta pieeons, the latter gradually attennate from hase to apex; under surface piceous-hrown, the legs and antennx flavate. Hearl strongly, sparsely punctate; eyes small. Prothmox more than twice as wille as long; basal bobe very broally, feethy arcnate; basal bead fine, flat, strongly marked, obsolete at laterial fourth; disk rery minntely, sprarsely punctate, the punctures rather denser and more distinct laterally; marginal bead very tine; apical angles right, very narrowly rounded. Scutellnm two-thirds willer than long; apex rounded; sides areuate. Elytra abunt three times as long as the prothorax, not narrowed behinl ; a prx $^{+2}$ very broally rounted; sirles coaretate with those of the prothorix; hasal stria rery fine, reflexed aiong the sentellum and obsolete opposite the apex of the latter' sutural bead very fine, attaining the apex of the scutellum; two diseal striae very fine but distinct, the first continuous from the suture at the apex and obsolete at basal fourth, the second approaching very near the first 
at apical sixth or seventh, obsolete at hasal thirl, sometimes also with traves of an incomplete third liscal stria; disk polished, not roticulate except coarsely and confusedly so at the apex and thence shightly along the sides, having even distant rows of very minute punctures, the rows not attaining the hase, the punctures eoarser and contused near the sides and apex ; intervals with uneren single rows uf excessively minute feeble punctures. Netasternum polisher, with scarcely perceptible sparse feeble punctures. length $2.3-2.6 \mathrm{~mm}$.

\section{New Mexico (Las Vegas); Dakota (Bimmarck).}

Althongh the elytrat are unmistakably vittate in this precirs, it cannot be considered a rariety of vittutus; its large size, dark head and prothorax, much hroader and more definite pale rittie, coarser, denser and more rugose punctuation at the sides and apices of the elytra, and especially the more coarsely punctate head, preclude any such ascociation.

The original unique type is immature, as there is no trace of the dark sutural stripe. The measurement given in the original description is too great.

O. pallipes fay.-Jouru. Ac. Phil., IV, p. 90.-Evenly elliptieal, very convex, highly polished, tark piceons-brown above; under surface, legs and antenne pale, flavo-testateons. Heul sparsely and very obsoletely punctate; eyes rather small; antenne rather robust, third joint almost as long as the uext two combined, club rather robust, scarcely as long as the first three juints combined, ninth triangular, a little wider than long, tenth trapezoilal, twiee as wide as long and distinctly wider and shorter than the ninth, elerenth as wille as the tenth, as long as the two preceding, but slightly wider than long, rather ahruptly constricted at apical thind forming a very distinet narrowly rommided apicial process. Prothorax at base twice as wide as the hearl, a little more than twice as wide as long, slightly lobed and feeloly bearled at the mindle of the base, very obsoletely and finely punctate. Seutellum small. a little wirler than long. Elytre two and one-half times as long as the prothorax, not narrowed behind, polisherl, not retienlate, with a fine transverse hasal stria, reflexed slightly along the scutellum where it becomes obsolete; sutural bead wanting near the hase, very tine thence to the apex ; discal stria two in number, the first extemling to basal fourth, the second a little beyom the mindle, the first miting with the suture at the extreme apex, the second ranishing without attaining the suture at apical fourth or fifth ; lisk with distant rather resular rows of excessively fine feeble punctures, which hecome slightly more visible but still in regular series at the sides, almost obsolete at hase, the rows not accompanied by impressed lines, the intervals excessively minutely teebly and obsoletely punctate in single irrexular lines. Abdomen rather distinctly and suluasperately punctate, plentifully but not densely pubescent. Legs molerate; posterior tibial spurs slender, rather long, the corresponding tarsi rather slender, densely pubescent beneath, two-thirds as long as the tibie, the 
first joint less than one-thirt as long as the secomd, apparently subancly-l, second as long as the fifth exclusive of the basal nonde, which is mulat dly robust and well marked. Length $2.6 \mathrm{~mm}$.

Kansas; Texas; Pennsylyania; New York.

The punctures of the elytral series are minute points, apparently absolutely non-setigeroms. The metastemal process extends beyond the coxa, and rests upon the inflexed prostemal process; it is strongly rounded at apex, very finely beaded throughout, and around the edges of the middle acetabular its surface is polished, with a few excessively minnte fechlo aml widely seattered sctimerous punetures; the sirles are sliphtly diveroent from apex to base, at which latter point it is about three times as wide as the prosternal process, and as wide as the length of the last antennal joint. 'There is sometimes a very short isolated third elytral stria.

The species described by LeConte as striatulus, I believe to be the same as this, and the ahove description is taken from the original type of striatulus.

o. semistriatus Lee-Proe. Ac. Phil., 1856, p. 16.-Rather narrowly and very evenly elliptical, stron pale rufo-testaceons beneath; legs, trophi and antenne concolorons. Head rather coarsely but not densely punctate; eyes moderate; antenne moderate, third joint fully as long as the n+xt two together, elub rather rohust, nearly as in pallipes. Prothorax twice as wide at base as at apex, distinetly bled in the middle at base, the edge sightly sinuate opposite the scntellum; basal bead distinet, becoming olsolete at one-fourth the width from the sides; surface very sparsely, unevenly, feebly punctate, the punctures subelongate. Scutellum molerate, wider than long, roumled at the sides. Elyfor three times as lony as the prothorax, strongly, evenly romoled at apex, polished, without reticnlation except very near the alex, not pereeptilly so at the sides; sutural bead very fine, continuous to within a vory short distanee of the scutellum; first discal stria joining the suture at the apex, vauishing at less than one-third the length from the base; second distinct, olsolete at onethird the length from the base and one-fifth or one-sixth the length from the apex, approaching but not uniting with the first; basal stria continuous along the scutellum; disk with series of very fine feeble evidently elongate punetures, distinctly stronger at the sides, and accompanied by distinetly impressed lines which are continuous to the base. Abdomen moderately pubescent. Legs rather rolust; posterior tibial spurs listinct, the corresponding tarsi threefourths as long as the tibia, with the first joint one-half as long as the second. Length 1.9-2.4 mm.

\section{Kansas; Atlantie States.}

The metasternum is polished, with very sparse fine pubesence, the punctures exeessively minute and entirely filled by the hairs, 
the process extending beyond the eoxa, strongly and narrowly romnded at apex, the mesosternum forming an apical border which is rory fine in the midlle but dilated at the sides and rather foehly declirons, so that it is rearlily visible in a perpendicular direction from below; it is moderate in willth.

The description is taken from an eastern specimen which is much larger than the Kansas type, as the latter is in very bad condition. The species greatly resembles pallipes, but seems to be distinet.

O. meglectus n. sp.-Evenly and not very broadly elliptical, strongly convex, highly polished, black: under surface piceous-brown; legs, trophi and antenne pale testaceons. Head finely but somewhat deeply densely and distinctly punctate; antenne rather rohust, third joint slightly shorter than the next two combinel, chb rather short, compact and robust, ninth joint triangular, wider than long, more pointed at the anterior side, tenth slightly shorter and wider than the ninth, much mores than twice as wide as long, more pointer on the anterior side toward the apieal angle, eleventh lyriform, slightly widt'r than the tenth, as long as the two preceding together. Prothorar of the usnal form, feebly lobed in the middle at base, the lolve evenly, feebly arcuate; basal beal distinct, becoming ohsolete at one-fourth the width from the sirles; disk extremely minntely, feeloly, sparsely punctate. Scutellum moderate, twothiris wilter than long, ogival; silles feebly arcuate; apex not rounded. Elytru two and one-half times as long as the prothorax, rather strengly romded at a "x, the sutural beal obsolete at nearly ons-fourth the length from the base, exessively fine; diseal strie very fine, the first continuing to within one-eighth the length of the base and joining the suture just lofore the apex, the second olsolete at tro-fiftlis the length from the base and one-fourth from the apex, at this point approaching very close to, lut not joining the first; surface with traces of very fine impressed lines, polisher, but with feehle traces of minute reticulation, which becomes very evident at the apex and also along the sides; punctures of the series excessively fine and feeble, becoming but slightly more visible at the siles, rather distant in the rows, the intervals punetured in single series which are almost as regular as the principal series, but composed of smaller punctures; punctures not elongate and each with a very ninute fine recumbent hair. Abdomen with coarse sparse pubescence. Legs rather slentler ; posterior tibie slender, spurs distinct, the corresponding tarsi threefourth as long as the tihice, with the basal joint scarcely one-half as long as the second, the latter subequal to the fitth. Length $1.8 \mathrm{~mm}$.

Vermont; New York.

The metasternum is polished and not distinctly punctate, haring fine, very sparse pubescence, the process adraneing but slightly beyond the coxie, evenly rounded at apex, with the mesosternum as in semistriatus, but less exposed at the sides of the apex. 
The hasal stria of the elytra is very fine and is reflexed along the scutellum, rather distant from the latter and not extending heyond it.

o. Infipes lece-Proc. An. Phil., 1856, p. 16.-Rather narrowly oval, fully three-finths longer than wide, rather distinetly attenuate brom from basal fourth of the elytra, polished, piceous-black alwre, testacenus bemeath, the metasternum and ablomen clouded with piceons; legs and antemna pale flaro-testacons. Head finely but rather strongly and distinctly punctate; antenne nearly as in cillahls. I rofhorar more than twice as wirle as long, with a hroal distinet median lobe at hase; basal lual distinct except towam the silds; surface fincly but rather distinctly, sparsely and somewhat unevenly punctate, the punctures attenuate pusteriorly. Scotellum ogival, onw-Jalf wiser than long. Elytre three times ar long an the prothorax ; sutural bear very fine, becoming obsulete npar the hase; diseal strise fine lut distinet, lowth becoming obsolete at hasal thind, the first coincident with the suture at the extreme apex, the second approiching but not joining the tirst at apical fourth or fifth; having also series of exceedingly minute simple punctures which are scarcely more distinct at the sires, the series accompanied by fine, feebly impressed lines which almost attain the hasal stria: surface with very ferble, densely crowted, longitulinally acicnlate reticulatims, which are extremely minute, more distinct at the sibles and especially at the apex, where they berome more ronmled and less aciculate. Alydmen sparsely pubescent, al ntaceous. Legs moderate; posterior tarsi simere three-fourths as long as the tihior, with the first joint about one-third as loner as the secont. leength $2.0 \mathrm{~mm}$.

Oregon. Cab. LeConte.

The metasternum is polisherl, althongh finely reticulate, rery flarsely, fincly punctate and pubenecnt; the process is rather wirto. projecting beyoud the eoxa, with the apex broally rounded, almost sultruneate in the middle, the mesosternum not distinct at the sindes.

This species differs from the preceding in its hroater, mone ohtusely rounded metasternal process, which is here alout as wide as the anterior femur ; in neglectus it is not much more than twothirds as wide.

O. Wickhami n. sp.-Llongate-oval, nearly twice as long as wille, more or less attenuate from anlerior third, llack ahove, piceous beneath; troplit, antenne, tibia and tarsi paler, rufo-testaceous; shining. Head very finely, sparsely punctate; antenne moderate in length, rather slenter, third joint as long as the next two together, chub of nearly normal form but slightly less strongly compressed, slightly more parallel and less rolust. Prohtorar but slightly more than twice as wide as long; sides less arenate than usual; basal lobe broadly arcuate ; basal bear very feeile; surface polished, not at all reticulate, extremely minutely, feelly and sparsely pnnctate. Scutellum molerate, ogival, nearly twice as wile as long. Elytru three times as long as the prothorax; sutural bead very fine, not beeoming entirely obsolete at the 
base, the single discal stria very dose to the sutnre, distinct, extending to basal thirl, coincident with the suture just before the apex: having rows of excessively minnte, feelole, posteriorly attemated punctures, attended by finely impressed lines which are continuons to the basal stria ; entire surface covered with a denserstem of short, closely crowled, longitudinally acioulate reticulations, which are strongly markel toward apex and the sides lont sometiumes very fieble or obsolete on the nplere portions. Aludomen polished, without the usual minute reticulation, rather coarsely, asperately punctate, very coarsely pubescent. Leys normal, not very rohust; posterior tarsi slember, three-fourths as long as the tibie, with the hasal joint about one-third as long as the seconk. Length 1.7-2.4 mm.

Southern (alifornia; Arizona; New Mexico.

The metasternm is excessively minutely, sparsely punctate, reticulate in way lines laterally; the process is rather wide, extending very slightly beyond the eoxe, broadly rounded and linely beated at apex, the mesosternum rery narrowly visible and derlisous at the sides in front of the coxe as uswal. The third joint of the maxillary palyi is distinctly lomger than wide, the fourth searcely wikler, elongate fu-iform and nearly twice as long as the third.

In one speeimen the discal stria does not quite attain the middle of the clytra, and in several other respects this species seems to be very variable. In the five typical representatives obtained by Mr. G. W. Dunn, in Sonthern California, or the northesn part of Jower Califurnia, the form is generally very slightly narrower than the majority of a large series taken by Mr. II. F. Wickham, at various localitien in Arizona and New Mexico, and the type has a distinctly longer derelopment of the metasternal process than can be olsecred in the others, this process gradually shortening ly insensible degrees, until in one of the broader forms from New Mexico, the mesostermum instead of heing deeply excavated under the apex of the process, is simply strongly declivous. There is also marked variation in the width of the process and its degree of obtuseness, in some specimens being very broadly rounded and in others very narrowly so, in the latter case learing much more of the dechrous mesosternum visible at the sides of the apex.

The dense acieulato-reticulate sculpture, which is unique, and the single discal stria, taken in eonnection with the sternal and tarsal eharacters of Olibrus, show that this species is an isolated and highly specialized form, withont any near congeners-although in rufipes there is a feeble indication of the seulpt ure here so highly developed ; and for this reason, as well as the fact that there appears to be no 
stahility in the variations observed, it is impossible to sperifically divide the large amount of material before ne.

\section{OLIHIROPORUS n. gen.}

Base of the antemute entirely exposed in derp fromtal rinarginations just before the eyes. Scutellum snall. Elytra with a single diseal stria, the sutural beal completely wanting. Jostelual process rather masrow, abmutly intlextel at ay+x, the latter not stotose. Mesosternum forming a minnte lueat alone the apex of the very bload, transvelsely truncate metasternal funcess, the latter not alvancing heyond the coxat, the mesosternum not drevelowed behind the midelle acetabula, foming merely a bealed margin. Lexg short and rohust ; terminal spurs of pusterior tilia small, slemler, slightly muedual; posterior tarsi molerate, eylimbical; lasal joint obliquely truncate and polonged beneath the second, the articulation rigid; second joint morlerate in length, scarcely twice as long as the first.

These few words will scrve to charaterize a genus intermediate in some charaters between Stilbus and Olibrus, and combining atso serral of the structural features of other genera. The apex of the prosternal process is more abruptly inflexed than is usual in Olibrus, but the edge is not as free and acute as in Stilhus.

O. punctatus u. sp. - Rather broadly, evenly elliptical, convex, strongly shining, black above, rufo-testaceons thronghout beneath; antennie same. Head short, very mimutely, rather feeloly punctate; eyes large, not margined internally; : antemne moderate, third joint nearly as long as the next two, club large, lomger than the funicle, elongate-elliptical, strongly compressiect, the eleventh joint but slightly longer than wide, cone-half longer than the tenth, the terninal process not well defined and obtusely combled. Prothorme very short, almost three times as wille as long, strongly narrowed from base ton apex ; sides areuate and continuous in eurvature with those of the elytra; basal lobe ahnost oksolete; basal beal fine, very strong and continuing to within a very short distance of the basal angles, the posterior margin of the basal bead finely gramulato-acienlate; disk very minutely, feebly and not very densely functate, the punctures rather larger and denser near the lateral edges; the latter margined with a broad flattened bead which becones very wide aromm the apical angles. Scutellum very small, slightly wider than long, pointerl; sides broadly arcuate. Elytro more than three times as loug as the prothorax, not narrowd toward apex, the latter very hroadly, evenly romded; transwerse basal stria fine, deeply impressed, abruptly ending at the base of the scutellnm, which it attains, but at which point it is not in the least reflexed antering half of the basal hear-formed ly the basal stria-longitulinally gramulate-aciculate; discal stria very teeply impressed, coincident with the suture at the apex, and very gradually evanescent at basal fourth, becoming an mimpressed row of punctures; disk rather coarsely reticulate in transwerse way lines, 
having nime very even rows of large, rather closely placed, deeply impressed and slinhtly elongate punctures, which are edual in size therghout the wilth, and unt in the least dilated laterally, the rows aluost attaining the base and not acennganied by impresser lines; intorvals flat, with nneven single rows of fine punctures. Metasternum shining, very fincly, sparsely, subasperately punrtate, coarsely and sparsely pulescent. Length 1.9 mon.

Floricla.

The widny spaeed, perfectly even rows of deeply impressed punctures, distinguish this speeses from any other of the family, but reall to a eomsiderable degree the punetuation of Phalacrus seriafles: in the latter, however, the series of the intervals are as distinct as the others, so that the regular rows are twice as numerous as in the sperius here describerl. The gemeral character of these punctares is perfectly similar to the prevailing type in Olibrus.

\section{EULITIUS Sharp.}

Hear extremely minutely but distinctly and not very sparsely punctate, with several laterer, widely dispersed punctures tow and the sicles of the front. libistoma transwersely, feebly arenate; sirles widely divergent postericrly, the antemal simations feeble, a very small portion of the hasal jorint concealecl. Antenme rathes long; hasal joint large, nuch longer and more robust than the secont; third searcely as long as the next two combined; onter joints of funiche slightly nure robust, the eighth willer than long; elub long, loose; nintl and tenth joints triangular, sulwegual in length, ninth to elerenth

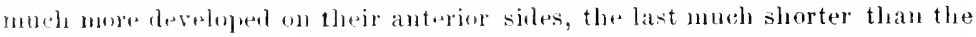

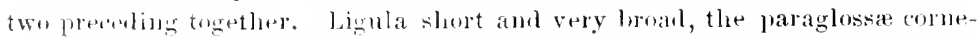

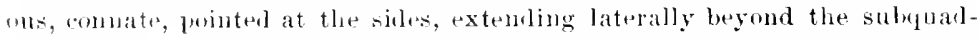
rate unoutum. Palpi robust ; last juint of the labial slightly swollen, as long as the two preceding; fourth joint of the maxillary subcylindrical, obtusely printed, as long as the two preceding together. Prosternal process intlexed at apex, mot at all setose, moderate in witth. Metastermal process very wirle and long, extending beyond the coxa and resting in repose upon the prosternal process which is teebly inpressed, strongly evenly rounded at apex. Mlesostermm forming a fine beated margin alomg the apex and coxal cavities, and expanded bohind the latter, beconing here about three times as wide. Lengs moderately robust; tibial sume long, strong, unequal; posterior tarsi rather long, rylindrical; hasal joint short, ahmost rigidly anchylosed to the second, and not extemding beneath it; secomd joini extremely long, nearly four times as long as the first and about one-half longer than the entire remainder, not very densely clothed throughout with short robust closely recumbent spinose setir ; fourth joint very distimet as a basal node of the last; third not in the least dilated, obliquely lober beneath.

In addition to the above characters, it should be mentioned that the elytra are entirely destitute of any trace of discal striæ, although 
the suture is very finely beaded, the head beeoming obsolete lufore attaining the base. The semtellum is small, and the clytra ale rendered feebly opalescent by an excessively minute transrise strigilation, which is just rosolvalule nuder a power of so. The punctures are small, feebly crescentilorm and disposed in rather approximate but not very legular rows, becoming wider and more confused near the sides.

The description is taken from the typical Central Amerian $L$. estriatus sharp, one of the larest and fincs species of thr fanily.

The aftinities of Eulitgus ale cridently strongly towam Olibus, and it bears very much the same rebtion to that genus that Arylomus bears to Stibus. The feenle dilatation of the mesostermmon behind the mitlde acetabula, shows also that it should form une of a series joining Olibrus and Acylomus or Stilbus. No species has yet been discovered within the United States.

\section{LITOLIBR US Shar?.}

The nearest ally to this genus is probably Acylomus, from which it differ's primarily in four important characters as follows:-

1. The mesosternum is not produced at all hehind the midile acetabula, being reduced to a simple fine bead forming the margin of the carity, as in Olibrus.

2. The metasternal process is very narrow and much shorter.

3. The sexual modification of the posterior tibia, tibial spurs, and tarsi does not apparently exist, and the seeond joint in the male is not spongiose beneath.

4. The basal joint of the posterior tarsi is extremely obliquely truncate at apex, and extends more or less beneath the second joint, this being more noticeable in the northern forms than in the typical obesns where, however, it is also very marked. In Acylomus the apex of the first joint is only slightly oblique, and its lower surfice does not extend at all beneath the second. In both genera the connection between these joints is rigid, apparently admitting of but little, if any motion, but the line of demarcation is rather stronger in Litolibrus than in Acylomus.

Both of the genera here compared differ greatly from Stillus in the very elongate second joint, and Litolibrus dilfers from Acylomus as well as Stilbus in its extremely robust legs, especially the middle and posterior femora and tibix.

This genus is one of the most distinct of the family, ranking, in Annals N. Y. ACad. Sci., V, Feb. 1890.-8 
the radical nature of its peculiarities of structure, with either Olibrus or Stilhus; it is essentially tropical, but extends into the southern limits of the United States, where it is represented by two species characterizerl as follows:-

Pale testaceous; elytra black, with the margins and two oval approxinate sputs just betore the midelle pale.............................princeps Pale ochreous-flavate throughont...

uniformis

L. princeps Schwarz.-Proe. Am. Phil. Sne., XVII, p. 361.-Rather broafly. evenly elliptical, molerately convex, polisherl; head, pronotum, a large oblique oval spot on each elytron before the midlle, attaining the suture, the lateral margin and apex narowly, entire nmer surface, legs and antenux pale rufo-testaceons; remainder of the elytra bick. Hrad polisherl, somewhat coarsely, sparsely and feebly punctate; eyes large, their inner margin slightly elevated ahove the general surface of the rertex; epistoma withont a beated margin, except laterally along the antennal sinuations; antenna ratler long and robust, joints three to five decreasing uniformly and very slightly in length, outer juints of funicle slightly more robust, seventh and eighth equal in length, the latter just visibly wider than long, chub rather roloust, strongly as rumetric, the anterior sides much more strongly angulate, and the eleventh joint slightly lobed on this sicle near the base, longer than the two preceding towether. Prothorax much more than twice as wide as long, not reticulate, very minutely and obsoletely, Jut somewhat densely punctate; basai lohe monluate, broally, evenly areuate, the basal bead fine, very strong, extending laterally to within one-fourth the wilth of the sides, with its posterior nargin finely and very strongly granulose. Scutelum equilatero-triangular, snall, thas siles very feebly arcuate. Elytra polisherl, the transverse strigilation so minute as to be merely suggested by a very feeble opalescence under ligh power, having rows of very small, rounded punctures which are larger, deeper and more distinct at the sides, always crescentiform, the intervals with an obseurely double line of nearly similar punctures; discal stria obsolete at basal third. Abdomen coarsely, sparsely pubescent. Lfogs short and very stout, the posterior tibia slust, obliquely truncate at alex, the truncation simute; spurs very long, stout, and distinctly nnequal, the corresponding tarsi nearly as long as the tibise, the first joint short above, very strongly prodnced beneath the second; second joint arcuate above near the base, nure than four times as long as the upper or shorter sile of the basal joint, and very much longer than the entire remainder. Length $2.6 \mathrm{~mm}$.

Florida. Mr. Schwarz.

The metasternal process is narrow and very short, flat, impunctate, truncate at apex, the mesosternum in front of it alnuptly declivous, and extending laterally so as to slightly envelop the middle coxe, having one or two robust seta at the sides near the coxa and metasternum, not at all prominent; prosternal process moderate, with two or three very fine feebly developed setæ. 
This is an extremely distinct species in many characters, esjecially those of the antenne, mesosternum and posterior tarsi, but it does not differ generically from $L$. obesus. The species described as varians by Dr. Sharp (Biol. Cent.-Amer. Col., II, i, 1) 260), does not appear to differ specifically, and, in accordaner with the theory of distribution by ocean currents from Central Aueriea to Florida, formerly beld hy Dr. LeConte (Proc. Am. Phil. Soc., XVII, p. 471 ), and more recently demonstrated by Mr. Schwal'z (Proc. Ent. Soc. Wash., I, p. 145), the proposed synonymy is rendered highly probable.

L. Wniformis n. sp.-Conewhat broadly, evenly oval, very stromgly convex, pale ochreous-flavate throughout, strongly shining. Head not reticulate, extremely minutely, obsoletely and sparsely punctate, with a few seattered punctures of larger size near the eyes ; the latter moderate, the inner margin and beaded edlge of the epistoma as in minceps; antenne molerate, funicle slender, third joint much shorter than the next two comlined, fonth slightly shorter than the fifth, eighth very slightly shorter than the seventh, a little wider than long, club robust, fusifom, nearly symmetrical, eleventh joint fully as long as the two preceding combined. Prothorar distinctly more than twice as wille as long; hasal bole very hroul and extremely feeble, the beal fine but strong, continuing laterally to within one-fifth the wilth of the sides, with the posterior margin finely and strongly granulose: surface polished and almost completely devoid of punctuation. Scutellum expilatero-triangular, the siles feebly arenate. Elytro distinctly opalescent, having wilely distant rows of moderate punctures, which are more deeply impresser and very distinct toward the suture, and more broally crescentiform but rather more feebly impressed near the sides and apex, obsolete towarl base; intervals with a few widely dispersed, excessively minute punctures; sutural stria distinct, obsolete at basal third or fourth, the transverse strigilation extessively minute and dense, not resolvable under high power. Aldomen reticulate, sparsely pubescent, the rows of robust sete at the apices of the segments especially prominent. Legs short and very stout; olliquity of truncation of the posterior tibix rather slight, the spurs long and strong, the tarsi rather slender, nore symuetrical than in princeps, the hasal joint less strongly proluced beneath the second, the latter seven or eight times as long as the first on the upper side, and slightly more than twice as long on the luwer sinle, sparsely chuthed with very short recumbent setæ, and much longer than the entire remainler. Length 2.4 nm.

Texas.

The metasternal process is very narrow, short, truncate at apex, the mesosternum before it moderately declivons, not at all prominent, and not much dilated over the coxic at the sides; prosternal process narrow, very strongly dilated at apex, where it is between 
two and three times as wide as at the narrowest part, the apical margin bearing two short stiff setre.

This species apprears to be distinct from any of those reently described hy Dr. Sharp; minor, which modoubtedly resmbles it in color and size, has the club of the antenne short and broad, and "developed on one sille only of the mesial line."

\section{ACYLOMUS sharp.}

Although bearing a certain general resemblance to Stilbus, this genus posicesses two pharacters which render it one of the most remarkable of the entire family.

The first character is not entirely peculiar, as it reappears to a less marked degree in Litoehropus; it relates to sexual modifications affecting the posterior tibise. In the males these increase strongly in wilth from base to apex; they are oldiquely truncate, and have the terminal spurs extremely unequal, the smatler being longer than usual in Stilhus, and the other greatly developed, being sometimes between onc-third and one-fomth as long as the entire tibia, and generally slightly contorted toward apex. In the female the tibiæe are normally and sometimes umusually slender, transversely truncate, and have the terminal spors of the rsual form, althongh murh longer, stouter and more mequal than in stillus.

The other character lelates to the vestiture of the under surface of the second joint of the posterior tarsi, which, in the males, is of a densely spongiose nature, similar to the under surface of the anterior taris in the males of Anisodactylus. This character seems to be ahsolutely peculiar to Acylomus, and is most highly developed in the typical A. acienlatus Sharp.

In the gemus Acylomus the serond joint of the posterjor tarsi is very nuch more elongate than in Stilbus, and the basal joint rorrespondingly abhreviated, the connection between the two being more rigil. The structure of the mesosternmm is nearly similar, but its extension hehind the middle coxa generally less, being intermediate in this respect between Stilbus and Litolibrus; it is also a connecting link betwen these two genera in the senlpture of the elytra, the reticulation of the surface when present in Stilbus being coarser and tending less to a transverse arrangement in wavy lines, while in Litolibrus it is very much finer, taking the form of a more regular transverse strigilation, of such excessive minutencss and close- 
ness that it eannot be distinetly resolved by the bighest ordinary working powers of the microscope; it is to this natural optical diffraction-grating, that the opalescence observalule in most of the species is due; the same effect from a similar cause is mole familiar to us, and even more strongly developed, in Sclenophorus of the Harpalini.

The elytral punctures prevailing in the genus are very strongly transversely erescentiform, being much more highly developed than even the most extreme eases which I have observer in Stilbus; this character is also very marked in the Litochride genera. The setæ at the apex of the prosternal process are less highly developed than in Stilbus, being generally shorter and sometimes reduced in number to two, situated at the apical angles. The metasternal process is geverally rather longer than in Stilbus, somewhat variable in width, and is usually slightly dilated at the immediate apex, the tumid mesosternum before it being almost invariably shorter.

The species are probably moderately numerous in the United States; the five which I have before me may be separated as follows :-

Color throughout the upper surface piceous or black.

Form evenly elliptical or suboblong, not at all attenuate behind.

Piceons, the crescentiform punctures of the series toward the snture wide and strong!y developed ; transverse strigilation somewhat coarser; form more feobly convex.

Setæ at the apex of the prosternal process uniformly two in number.

calcaratus

Setre more robust, four or five in number; form of body much more elongate ...........................................extricatus

Intense black, the punctures of the series toward the suture very fine and feeble; transverse strigilation very much finer; form more convex.

ergoti

Form broally oval, distinctly attennate behind from the base of the elytra, pale piceons, the elytra very minutely strigilate

piceus

Color castaneous, the head, pronotum, apex of the elytra, and two discal spots near the base of the latter pale rnfo-testaceons.

nebilosins

A. calcaratus n. sp.-Almost evenly oval, more broadly so and less convex in the male; piceons alove, under surface, legs and antenne pale Havo-testaceous; lustre subalutaceons. Head extremely minutely, rather sparsely punctate, polished, not distinctly reticulate; eyes large; antenne molerate in length, rather slender, third joint slightly shorter than the next two together, fourth much shortel than the fifth, onter joints of funicle just visibly stouter, seventh a little longer than the eighth, the latter rather longer 
than wise, elub rather slender, symmetrical, nintl joint longer than wide, longer than the tenth, the latter slightly transverse, eleventh nearly as long as the two preceding together. Prothorax more than twice as wide as long, distinctly, broadly lobed at the middle of the base, and finely but distinctly leaded; surface excessively minutely, sparsely punctate, polished toward apex, very minntely strigilate in wavy transverse lines which are distinct toward liase and obsolete toward apex. Scutellum ogival, nearly as long as wide. Elytra finely and very distinctly strigilate in transverse way lines throughout, having rows of broally crescentiform, feebly impressed punctures, which are but slightly wider at the sides, where they are more alproximate laterally, and becoming obsolete near the base; discal stria distinct, obsolete at hasal two-fifths. Abdomen coarsely, sparsely pubescent, shining, coarsely reticulate. Legs molerate, the posterior femora not unusually robust; tiliæ feebly dilated from lase to apex, the apical truncation slightly oblique, very sparsely setose, having an intermal and external line of fine erect sutiform spines, the terminal spurs extremely mequal, the larger feebly contorterl, as long as the apical width of the tibia; corresponding tarsi very slender, cylindrical, with the second joint nearly four times as long as the first, and longer than the entire remainder, the under surface spongy-pubescent only in the apical half. Length 1.4-1.7 mm.

\section{Texas (Galveston and Austin).}

The description is taken from the male; the female has the posterior tibie nearly equal in width throughout, and rather slender, the terminal spurs smaller and more slender, but decidedly unequal, the longer one being still as long as the apical width; the tarsi are more slender, with the seeond joint rather shorter and not spongiose beneath.

The metasterum is very minutely, sparsely punetate, very sparsely pubescent, the process very wide, rather long, slightly and abruptly dilated at the immediate apex, the mesosternum in front of it transverse and very short, not distinctly tumid, the prosternal process rather wide, the free apex very feebly, broadly arcuate, and having but two short spinose setæ-one at each angle.

A. extricatus n. sp.-Elongate, evenly elliptical, nearly twice as long as wirle, piceous above, dark rufo-testaceous throughout beneath ; elytra subalutaceous. Head very strongly retractile; antennæ moderate, outer joints of funicle slightly rolnst, club very distinctly increasing in wilth from base to apex, ninth joint scarcely longer than the tenth, the eleventh as long as the two preceding together. Prothorax lut shightly more than twice as wide as long, very broally, strongly lobed in the middle of the base, the beaded margin distinct; surface polished, very minntely, transversely strigilate in wary lines which are very distinct toward base and nearly obsolete toward apex. Scutellum very small, ogival, slightly wider than long, the sides strongly arcuate. 
Elytra more than three times as long as the prothorax, having rows of molerate erescentiform punctures which, at the sides, becone very strongly transwerse, sometimes contluent, and more or less confused in arrangement; intervals toward the suture each with a row of similar punctures, but about one-lialf as wide; discal stria distinct, obsolete at basal third; surface rather coarsely strigilate in wary transverse rows throughout. Abdomen nearly as in culcuratus. Legs moderate. Length $1.8 \mathrm{~mm}$.

\section{Texas.}

This species is closely related to calcaratus, but differ's in its much more elongate, slightly les. convex form. It is described from the female, and the posterior tibial spurs are rather less developed and less unequal than in the corresponding sex of calcaratus; the tarsi are nearly similar in structure. In calcaratus the apex of the prosternal process has, without exception, only two terminal setie, while in the present specics there is a row of four or fice which are longer, and nearly twice as stout; this constitutes one of the most decisive points of difference between these species. The head is so far retracted within the prothorax in the type as to be invisible from above.

A. ergoti n. sp. (Walsh MS.) —Strongly convex, almost evenly elliptical, one-half to two-thirls longer than wide, the male slightly the shorter, black ahove, pale t'avo-testaceous thronghon heneath; lustre strongly shining. IIead very minutely, sparsely punctate, polished, not reticulate; eyes rather large; antennæ nearly as in calcaratus, but with the outer joints rather more rolust, and the clnb more strongly narrowed from apex to base. Prothorax polished thronghont, towarl base excessively obsoletely transversely strigilate in wavy lines, the punctures extremely minute and sparse; basal lohe and beaded margin distinct, the latter not extending laterally further than the lobe. Scutellum equilatero-triangular, with the sides very feebly arcuate. Elytra subalutaceons, very minntely, transversely strigilate in wavy lines, having rows of puncturs which, toward the suture, are very minute and feeble, and toward the sides slightly larger, always transversely crescentiform; discal stria distinct, obsolete at hasal two-fifths. Aldomen coarsely reticulate, moderitely slining, orarsely, sparsely pulescent. Legs molerate; posterior tilibe increasing very rapilly in wilth from base to apex, very obliquely trmeate; spurs nearly as in relcuratus; tarsi very long and slender, three-fourtlss as long as the tibire, with the second joint between three and four tines as long as the hasa!, and spongiose throughout beneath, except at the immediate base. Length 1.S-2.2 $\mathrm{nm}$.

Pennsylvania; Delaware; Iowa; Texas.

The deseription is drawn from one of the Iowan males; the female is larger, rather more eonvex, and has the posterior tibia 
more slemder, the spurs being smaller and less unequal than in the female of crlcaratus, the longer one much shorter than the apical wilt bo the tibia.

The stcrual structure is nearly the same as in calcaratus, but the metastornal process is rather less broad, and the mesosternum is more dereloped behind the midlle acetabula. The terminal setre of the prostrual process are alout three in number, extremely short, being much shorter than in calcaratus.

This species is widely distributed, and differs from the precerling in its laryer size, black color, more convex form, finer elytral seulpture aud punctuation, more especially in the rows towarl the suture, anr, more deeidedly, in the greater dilatation and obliquity of truncation of the posterior tibixe in the male. It varies considerably in size.

A. piceus n. sp. - Broally oval, rather pale fusco-piceons above, very pale brownish-flavate throughout beneath, pulisherl, the elytra feebly alutacens, moderately envex; sides feebly convergent behind from the base of the elytra. Heud not reticnlate, extremely finely and feebly punctate; eyes molerate; a] ical maroin of the front with two minute forese on each sidu just alove the insertion of the antenne, the latter rather slenter, the third foint distinctly shorter than the next two together; club elongate, very slender, symmetrical, paralle] and rather loose; ninth joint slightly longer than wide and a little longer than the tenth, the latter nearly as long as wide and not wider than the ninth, the eleventh elongate, nearly as long as the two precerling, obtusely rommed at the apex, without trace of terminal process. Prothorax between two and three times as wide as long, very strongly narrowed from base to apex; hasil lobe very feeble, the beal strong but very short, not extending laterally bryom the lobe; disk with feelle traces of transverse reticulation toward base; punctures ahmost obsolete. Scutellum scarcely wider than long, ogival, with the silles slightly areuate. Elytre rather short, about two and one-half times as long as the prothorax, ernly and not very hoally romeled at apex; surface very minntely and ratlee strongly transversely strigilate in wavy lines throughout, except near the base, where the sculpture becomes very feeble, having series of small transversely crescentitorm punctures, which are feebly impressed and which are not much wider or more distinct toward the sides, the series accompanied by fine feebly impressed lines, the intervals with uneven series of excessively minute feelble punctures of the same nature; all the punctures becoming gralually obsolete in basal third; thiscal stria fine but distinct, olwolete at basal third. Length $1.9 \mathrm{~mm}$.

District of Columbia. Mr. Ulke.

The deseription is drawn from the male, the posterior tibise being gratually strongly dilated from base to apex and very obliefuely truncate, the spurs long and very mequal, the posterior tarsi long 
and extremely slender. The metasternal process is ratler narower than usual in this genus.

A. nebulosus n. sp.- - Very broadly oval and moderately convex, alout one halt longrer than wide; elytra ferely attenuate from base to near the apex, then conjointly evenly rounded, subahtuacens, castaneous; heal, promotum, each elytron obliquely at apex, and a small indefinite spot at the base of each elytron, nearer the humerus than the scutellum, paler, rufo-testaceons; under surface, legs and autenne very pale testaceous. Hecul extremely minutuly, sparsely punctate, not reticulate; eyes morlerate; antenno slemler, joints one to eight elongate, club moderate, the eleventh joint about as long as the two precerling together. Prothorax distinetly more than twice as wirle as long; basal lobe very lowal, feeble, transverse opposite the scutellom; beinl fine but raflser slistinct, not extending laterally beyond the lobe; surface polished, extremely minutely and obsoletely pmotate, very feebly strigilate in wavy transverse lines which become almost obsolete toward apex. Scutellum ogival, slightly wider than long. Elytre strongly and distinetly, but very mimtely strigilato-reticnlate in broken transverse wavy lines thronglout, alutaceous in lustre, having series of very small feeble crescentiform punctures which become larger laterally, and rather confused near the sides; intervals each with a very irregular line of similar though extremely fine ponctures; discal stria fine but distinct, obsolete at basal fourth. Abdomen reticulate, very sparsely pubescent. Legs moderate, the posterior femora not numsually robust. Length $2.2 \mathrm{~mm}$.

\section{California (Fort Yuma).}

The posterior tibie are but slightly more robust and dilated in the male, the terminal spurs in that sex being extremely unequal, the longer nearly three times as long as the shorter, and rather longer than the apieal width, the corresponding tarsi being rather robust, the secoud joint nearly four times as long as the first, and slightly longer than the entire remaindes, spougiose along the mid dle heneath tbroughout the length, the spongiose area being linited laterally, as usual, by two lines of long, very closely-plaerd and slender sotie; first joint not at all produced beneath the second, the attachment apparently rigid. In the female the spurs are nnaller and more nearly equal, the larer but twice as lomg as the smaller, the tarsi more slender, especially the second joint which is not spongiose beneath.

The metasternal process is very broad, and the sternal structure in gereral very similar to that of the typical forms.

The seta at the apex of the prostermal process appear to be normally three in number, but the mirlule one is oceasionally absent, and there may sometimes be one which is superfluous and sporadic. In 
the female they are more than twice as long and stout as in the male, being extrumely minute in the latter sex.

The liscerery of this peculiar secondary sexual eharacter proves that these terminal setie play a mole important part in the economy of the inseret than has been hitherto supposed, and that the gap separating those genera possesing them from those in which they are wanting, as for instance Stilbus and Olibrus, is even correspondingly greater. It also indicates that any classification of the speres in genera poscessing these setie, based in any way upon them, must be: used with more or less eaution. It is only fair to state, however, that I have not been able to discover similar sexual variation in Stilhus, where I have separated sereral species because of the abnornal shortness of these setre, and in this particular case it is of very little consequence, as the four species constituting the secour group are so distinct in other characters that they can be easily identified, and after all this is the main object of taxonomical tables in such preliminary and superficial studies as the present is necessarily forced to be.

The terminal setre in $A$. calcaratus also differ sexually, but only to a slight degree, being a little longer in the female; they are, in that species, very persistently two in number.

Besiles being aborant in this way, the present species fliffers greatly in coloration from the others, reminding us somewhat, hut in facies only, of Stilbus viduus. It also appears to resemble the Central American Olibrus submaculatus Sharp, especially in coloration, but the sculpture and punctuation seem to be mucb more pronounced aud erident than in that species.

\section{LIOPHA LACRUS Sharp.}

The single specimen of the typical $L$. bicolor before me is in a very imprerfect state, so that I cannot examine the mouth.parts or antenne; otherwise it is extremely elosely allied to Stilbus, and differs only in the structnre of the posterior tarsi, which are comparatively short and slender, eylindrieal, with the proportional lenth of the joints as in Stilhus, hut with the first joint rigidly anchylosed to the seeond. The second joint is not remarkably long, and not quite twice as long as the first, the third being slightly dilated and deeply emarginate above. In Stilbus the articulation 
between the first and second joints is much less rigid and the motion apparently perfectly free.

In L. bicolor the metasternal process is wide, strongly rounded throughout at apex, and does not extend to the antrior limits of the coxa; the mesosternm in front of it forms a perfectly flat transverse piect, rather long, projecting beyond the coxse, with the apex transversely truncate, and the surface bearing a transversely areuate row of robust reeumbent spinose setre, projecting posteriorly, the line of demarcation between it and the mesosternum extremely fine. Behind the middle acetabula the mesosternum is very strongly developed, the picce being posteriorly produced in a slender cusp, extending almost to within one-third the length of the metasternum of the posterior margin of the latter. 'The prosternal process is rather wide, the posterior edge being free, acute, transversely truncate, and bearing a series of four or five erect rohust and prominent spinose setie.

On the upper surface the sutural head is entirely ohsolete, and the single diseal stria fine, elose to the suture, and rather short. The seulpture consists of very fine transverse strigilation which, however, is not sufficiently fine and close to produce an opalescent lustre. The punctures throughout are extremely minnte and feeble, not transversely crescentiform, and not more distinet at the sides, in this respect being exactly similar to many speeies of Stilbus.

No species of this Central Ameriean genus has yet occurred within the United States.

\section{STILIUS seid.}

Olistherus $^{1}$ Seid. ;-Eustilbus ${ }^{2}$ Sharp.

Some of the structural characters distinguishing this genus have been before indieated, and it is only necessary to state in general that it differs from Olibrus in its short metasternal process, prominent and tumid mesostermm, axtension of the latter hehind the middle acctabula, in the form of the prosternal process which is here furnished with a distinct free edge posteriorly, and armed with a transverse series of stout setiform spinnles, in the absence of a bead along the elytral suture, in the form of the eleventh joint of the

1 This is not, properly speaking, a pre-ocenpied name, Olistherus being to some "xtent different from Olistherns.

2 Biol. Cent.-Amer., II, Pt. 1, p. 253. 
antenma which is not constricted in apieal third, and in the form of the fourth joint of the maxillary palpi which is distinetly mores rohust and securiform.

It resembles Olibrus in the mode of antennal insertion, but differs radically in this respect from Phalacrus. Its relationship with Arylomms and Litolibrus has been mentioned under those genera.

The postorior tibial spurs are generally very small, slender and submpual, and in some species beeome quite as insignifieant as in Phalarelus. The hasal joints of the posterior tarsi are simply densely sctuse heneath, the second joint being lut moderately elongate, generally nearly twice as long as the first, but in nitudus relatively shortor and but slightly longer than the first. The seupture varies from the completely polished, as seen in apricalis, to a rather cuarse and rery strong reticulation throughout the uppre surface, as seen in subulutrcens. The punetures are gencrally very minute and ob-inure, sometimes almost completely ohsolete, the broadly crescentiform type being rare and exceptional. In pusillus, modestus, attemutus, and elongatulus, thr punctures hecome deeper and more distiurt on certain limited portions of the elytral disk.

Our speries are moderately abundant, usually widely distributed, and are somewhat diversified in structure. The four species assigned to group II, differ each very greatly from those of group I, in screral peculiarities of structure or sculpture, but at the same tintr differ from each other to quite as great a degree. In qeneral, the retionlation of the elytral surface, when present, is relatively somerhat coarse, and does not exhibit the transrersely way lines so prefectly as in Acylomus; in concergens and attemuatus it is replaced by a very minute wavy strigilation which, however, is not sufficiently fine to produce an opalescent effect as in Litoliblus.

The following table will probably enable the student to recognize those suecies which I have been able to sturly :-

Spinules at the apex of the prosternal process long and conspicnons

l'unctures of the second and third elytral series not more distinct in the milille.

Elytra either entirely pale or very distinctly paler at the apex.

Elytra highly polished, not reticulate except sometimes very feebly toward apex; punctures excessively minnte and scarcely visible.

Elytra paler at apex.

Form narrowly oval, piceous, each elytron abruptly and olilignty paler at apex.. 
Form broadly oval, color pale castaneous; pale area at apex not

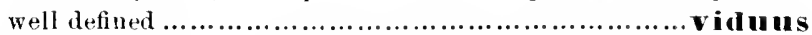

Elytra entirely pale...................................palidus

Elytra reticulate throughout.

Very small, strongly convex, the elytra acutely rounded loehind; punctures obsolete; color pale throughout

nitidus

Larger, more depressed.

Pale reddish-tlavate throughont; punctures of the elytral series distinct, at least toward the suture.

aquatilis

Dark piceous-brown, the apex abruptly paler; punctures obsulete.

Elytra piceous or piceoms-black throughont.

floridanus

Elytra finely reticulate throughont, larger species, moderate in size.

Eighth joint of antenme elongate.

obsculas

Eighth joint slightly transverse, and much shorter than the seventh.

obtusus

Elytra highly polished, not leticulate; very minute species.

manumas

Punctures of the second and third series from the discal stria composed of punctures which are large, deep and distinct in the middle third, but obsolete towarl base and apex.

Lateral series composed of very minute, nearly obsolete punctures.

pusilus

Lateral serjes composed of widely dilated, crescentiform punctures.

modestus

sirumles at the apex of the prosternal process short II

Discal stria very short and feeble, not extending beyond the middle: body evenly elliptical, piceous-black, strongly reticulate ....subalutaceus

Discal stria normal, obsolete at basal third: body attenuate behind from the base of the elytra.

Elytra very minutely, transversely strigilate: color pale testaceons throughout.

Punctures very feeble; metasternal process very wide, the mesostermum in front of it short, transverse and tumid

convergens

Punctures distinct and rather distant; metasternal process narrow, shorter, the mesosternum before it long, rather narrow and flat.

attemuat ins

Elytra more coarsely reticulate in transverse wavy lines; color intense black above; punctures of the series rather close and very deeply impressed thronghout the width.

elongatulus

S. apicalis Melsh._Proc. Ac. Phil., II, p. 102.-Oval, strongly convex, very feebly attenuate behind the middle, about two-thirds longer than wile, highly polished, piceons-black; apex rather abruptly pale testaceons, the general blackish tint being prolonged along the suture nearer the apex; under surface rufo-testaceons; legs, antenna and trophi paler and more flavate. Heal polished, excessively niuntely, feebly and very sparsely punc- 
tate; antenne slender, third joint not as loug as the next two combined, seventh longer than wide, eighth shorter, slightly wider, slightly trapezoilal, a little longer than wide, chub elongate, slender, compact and parallel; ninth joint olsconical, slightly longes than wide, longer than the tenth, and twothirds as long as the eleventh, the latter oval, three-fourths longer than wide, not constricted, narrowly rounded at apex. Prothorax slightly more than twice as wide as long, length equal to apical width; basal lobe very texple; basal bearlobolete; punctures almost obsolete. Scutellum ogival, two-thirds wider than long. Elytre distinetly longer than wide, rather narrowly rounded at apex; sutural bead entirely wanting; discal stria very deep amd strongly impressed, coincident with the suture at the apex, disappearing at lasal fourth; surface smooth, highly polisherl, without retieulation, the punctures of the series simple, very minute, distant and excessively feeble, not beconing more distinct at the sides. Aludomen feethy reticulate in wavy broken lines, sparsely, asperately punctate, a transverse row of punctures along the apex of each segment nore evident, coarsely pulescent. Legs morterate; posterior tibial spurs very small, slemder, not very nnequal; corresponding tarsi slender, nearly three-fourths as long as the tibie, basal joint scarcely onehalf as long as the second, the articulation perfectly free and mobile. Length $1.9-2 .+\mathrm{mm}$.

\section{New York; Iowa; Texas; California.}

The metasternal process is ratber narrow, extending about two. thirls the length of the coxe, the mesosternum being strongly developed in front of it, and slightly tmid. The post-coxal plates are namowly and very feebly prolonged behind.

This common species, which serms to vary considerahly in distinctness of coloration, is quite different from the European comsimilis, in form, size, coloration, and expecially sculpture. The entire surface of the European insect is minutely, but distinctly strigilatoreticulate.

S. viduus n. sp.-Broally oval, feebly attenuate behind from anterior third, one-half longer than witle, ohtusely rounded at apex, highly polished, rufo-piceous, each elytron oblicuely paler at apex; under surface, legs and antenne paler and more flavate. Heul almost conpletely impunctate; antenne rather long and slender, third joint slightly shorter than the next two together, fourth a little shorter than the fiftls and crual to the sixth, club rather elongate, becoming broader from base to apex, the eleventh joint rolnst, the compressed apex rather transversely truncate and subangulate at the sides, very nuch wider than the ninth. Prothorex not definitely punctate; basal lobe and its bearlerl edge almost obsolete. Sultellum small, ogival, searcely one-half wider than long. Elyfral punctures and discal stria nearly as in apicalis, the punctures more nearly obsolete, and more deciledly visible in the lateral series. Abdomen rather sparsely, criarsely pubescent, asperately punctate. Legs rather short and slightly robust; posterior tibial spurs short, subetual, 
robust; posterior tarsi nearly three-fourths as long as the tihite, somewhat robust, the basal joint one-half as long as the second. Length 2 .: inm.

North Carolina; Texas; Arizona.

This species resembles apicalis in seupture, hut is deciledly more robust, paler in color, with the apical pale area less defined than in the mature speeimens of apiralis; the sternal characters are nearly as in that speeies, but the antennal elub is more robnst toward apex, and the tibial spurs are also more robust.

The type is a male and exhibits the strongest sexual characters which I have observed in the genus. The third segment of the abdomen has, just before the apex, a short broad porrecturt tooth in the middle, which does not extend beyond the apical margin, and bears along its apex seven or eight rery short rohust porrected spinnles. The fourth segment has a fecble median impresion, and the fifth has the usuat very feebly defined transverse impression near the apex.

S. pallidus n. sp.-Evenly elliptical, about two-fifths longer than wide, polished, pale flavo-testaceous thronghont. Itead very finely, feehly punctate; antenne slender, club slender, compact, third joint scarcely as long as the next two combined, fourth shorter than the fifth. Prothorax very ristinctly more tlian twice as wille as long; punctuation obsolete; basal lobe extremely feeble, the bead obsolete. Scutellum ogival, wider than long. Elytra nearly as in apicalis, except that they are less attemuate and rather more broally rounded behind, uniform testaceons in color, and with a very feeble obsolete reticulation near the apex. Aldomen very feebly reticulate, the reticulation very fine, dense and strong toward the base of the hasal segment. Leys moderate or rather short; spurs of posterior tibize very small, slender ; posterior tarsi three-fourths as long as the tibie; hasal joint two-thirds as long as the second and more robust; first and second sparsely, finely spinose beneath ; third slightly dilated, bilobed, with a tuft of whitish hair beneath. Isength $1.9 \mathrm{~mm}$.

Rhode Island.

The sternal characters are nearly as in apicalis, from which this species differs in its smaller size, pale uniform eolor, relatively slightly longer basal joint of the himi tarsi, and finet, stronger and denser reticulation along the base of the abdomen. The reticulation at the apices of the elytra, although very feeble, is more distinet than in apricalis, where it is all but totally obsolete; in pallidus it is distinetly traceable over most of the apical half of the elytra, being especially noticeable in lines accompanying the series of punctures. 
The sprecies is represented by two speeimens which do not indicate any rariation.

S. mitidus Melsh.-Proc. Ac. Plil., II, p. 102.-Pale redilish-flivate thronghout, very conves, strongly shining, totally impunctate, the fine recunbent hairs rather long. Ifend very feebly reticulate in transverse wavy lines; antenne rather robust, third joint shorter than the next two together, distinctly clavate, fourth shorter than the fifth, outer joints of funicle more robust, club molerate, slightly more robust toward apex, ninth searcely longer and a little narrower than the tenth, eleventh two-thirds longer than the tenth. Irmthorax rather more than twice as wide as long, very obsoletely reticulate; basal lolse and beal almost completely olsolete. Scntellum ogival, wider than long. Elytra slightly attenuate and narrowly rounded at apex, the discal stria very narrowly separated from the suture at apex, obsolete at basal third; snrface minutely and distinctly reticulate in transverse wavy lines througliont, the minute recumbent hairs arranged in regular series, the punctures not evilent, each being entirely filled by the hair. Aludmen feebly, coarsely lesticulate, distinctly asperately punctate, coarsely pubescent. Legs rather short and robust; tibia short and broad, coarsely spinose; terminal spurs of the posterior very minute, subequal, not longer than some of the spinnles of the terminal fimbria; corresponting tarsi short, very slightly longer than the anterior, the basal joint relatively long, about three-fourths as long as the second which is shorter tham usual. Length 1.3 mm.

New York; Iowa; Texas.

The metasternum is reticulate at the sides, the process moderate in wilth, coarsely sparsely setose, the mesosternum in front of it much broader and distinctly prominent.

This minute species is very distinct and, as far as $I$ have seen, has no very close allies; it is the only species in which the punctures of the elytral series become completely in risible, and confused with the fine reticulation of the surface. In very pale specimens the chitinous cells of the elytra surrounding the base of the hairs become darker, giving the appearance of series of coarse areola or punctures hy transmitted light and under low magnifying power. The form of the body is extremely convex, resembling some of the small convex species of Cercyon.

The minute setigerous punctures of the elytra, described under Phalacrus, are observable here to a very limited extent.

S. aquatilis Lec.-Proc. Ac. Phil., 1856, p. 17.-Almost evenly elliptical, about two-thirds longer than wide, ochreous-flavate throughont, shining. Head excessively finely, sparsely punctate and very finely, feebly reticnlate; antenne nearly as in nitidus. Prothorac rather short, much more than twice as wille as long; basal lobe very broad and extremely feeble, beal almost 
amplotely obsolete; surface very minutely lunt distinctly reticulate in broken transverse wary lines, the punctures very sparse and just visible. Sontellum tielly retieulate, ogival, with the siles strongly areuate, one-half wider than lomg. Elytra very fechly attenuate from before the middle, revenly rounded at alex; discal stria as in obtusus; surface finely lut strongly and distinctly reticulate in way lines. snbalntaceous in lostre; punctures of series very evilent, coarser and distinctly crescentiform in the rows towarel the suture and the sides, smaller and feebler but still distinctly crescentiform in the median rows. Abdomencoarsely pubescent, distinctly reticulate, rather strongly, asperately punctate, especially as usual toward the midlle and apex. Legs murterate; posterjor tibize rather slenter, sparsely and coarsely setose; spurs suall and rather distinctly unepual, not longer than the outer s]inules, the same tarsi setose beneath, moderate in length, with the basal joint one-half as long as the second. Leligth $1.8 \mathrm{~mm}$.

\section{C'alifornia.}

The metasternum is reticulate but not distinctly punctate, rery sparsely and rather coarsely pubeseent; the sternum and sternal processes throughout are nearly as in obtusus, from which this - precies differs in its pale color, more distinct reticulation, and very notably in the character and strength of the elytral punctures. It is rare, and although fortunate enough to secure a single specimen myself, I am not certain of the exact locality ; it is, however, prohably southern.

S. floridanus n. sp. - Rather broadly oval, convex, widest a little before the midtlle, dark piceous brown above, with the apex conjointly aud rather abruptly paler, the anterior margin of the apical pale area posteriorly angulate in the middle, paler, flavo-testaceous throughont beneath, polished. Hrad extremely feelly, finely reticnlate, the punctures very sparse and excessively minnte; eyes molerate; antenne slender, the chb abrupt, rather small and stemder and scarcely as long as the five precerling joints combined, ninth and tonth joints subetpual, slightly transverse, eleventh oval, longer than wide, whinsely rounded at apex and rather shorter than the two preceding. Prothorax short, nearly three times as wide as long, with the feeblest possible trace of transverse reticulation toward the base and sirles, the punctures rery sparse and excessively uninute; base transverse, with a small feeble sinnation at each side of, and at some distance from, the sentellum; basal bead very line, the stria disappearing at lateral thirl. Scutellum small, triangular, che-latf wider than long, the sides and apex rounded. Elytra fully three times as long as the prothorax; sides more strongly arcuate at basal fourth or fifth, thence feebly convergent behind and very feebly arcuate, the apex rather abruptly and somewhat narrowly ronnded; basal stria very tine, reflexed along the scutellum; surface very finely reticulate throughout, the sculpture beconing very feeble toward hase, the reticulations not forming rery well-defined transverse wary lines; single discal stria fine but distinct, thisAxsals N. Y. ACad. Sci, V, Feb. 1890.-? 
appearing at basal third or fourth; disk without impressed lines, the punctures of the distant series olsolete thronghout the width, and only indicated by the extremely minute recumbent hairs growing from slightly more marked retal lines at their points of origin. Under surface and legs normal, the second joint of the posterior tarsi short, alout one-half longer than the first: tibial mpurs very small and slemter. Length $1 . ; \mathrm{mm}$.

Floridal (Lake Poinsett). Mr. Schwarz.

I small speedes allied to apiralis and consimitis, but distinguished] from the former by its smaller. size, more broadly oval, less convex and more posteriorly attenuate form, and elytral reticulation, and from the latter by its shorter prothorax, nore abruptly mallied apical pale area, less convex form and other characters.

S. obscurus n. sp.-Pather broally oval, piceons above; antenne, lears and under surface pale testaceons; upuer surface polisherl. Head estrenety feebly and sparsely punctate; antenne rather slender, third joint shorter than the mext two together, fourth much shorter than the fifth, club rather slender, sides nearly parallel, ninth joint much longer than the tenth and slightly shorter than the elecenth. Prothorue searcely visibly and very sparsely punctate, not reticulate; loasal lobe very broal and feeble, the marginal learl almost obsolete. Scutellmm one-half widler than long. Elytro more stronsty narrowed behind in apical half, rather strongly rounded at apex, nuicolorus or sometimes very feebly paler toward apex; diseal stria strong, olsolete at basal third or fourth, punctured as in apiculis; surface finely, feebly lut dis. tinctly reticulate, the reticulations visible over the entire surface except in the vicinity of the base, where they become obsolete, generally in very broken wary lines on the nuper portions of the disk. Ablomen very strongly reticnlate, the portions very near the base, and also the metasternum toward the sides, ahust granulose. Legs moderate; posterior tarsi rather short and robust, scarcely two-thirds as long as the tibize, setose beneath, the first joint two-thirds as ling as the second; tibial spurs small. Length $1.8-2.0 \mathrm{~mm}$.

Iowa. Mr. Wickbam.

The metasterual process is rather wider than in apicalis, and the mesosternum in front of it is very strongly tumid and prominent. The sexual characters are nearly as in viduus, except that the tooth of the third segment is more deflexed, with the spinules excessirely short. This species is rery easily distinguishable from apicalis and videres hy its small size, more rounded form, dark piceous color, which does not become noticeably paler at apex except from the transprency of the elytra, and by the reticulation of the ruper surface; it is represented by a good series of specimens, and does not rary appreciably. 
S. obtusus Lec.-Proc. Ac. Phil., 1856, p. 17.-Ahnost erenly elliptical, moderately convex, blackish-piceous thronghout the body, lers and antenne; tarsi slightly paler; upler surface shining. Mead resy fechly and sparsely punctate; anteme nearly as in nitides, but with the ninth joint rather longer. Prothorar extremely minutely, feebly and sparsely punctate, extremely obsoletely reticulate in broken wayy lines; basal lobe very hoad and feeble, the beat very fine but somewhat distinet. Scutellum one-halt wider than long. Elytra rather obtusely ronnded behind, finely but rather distinctly reticnlate in transverse wary lines over the entire disk; discal stria very strong, coincident with the suture at the apx, hecoming obsolete at basal third or fourth; punctures of the series very fine and feeble but visible, not more distinct but rather wider at the sides, where, howerer, they do not becone crescentiform, but simply a slight deepening of the lines forming the reticulation at the points of attachment of the hairs. Abdomen reticulate, sparsely, coarsely pubescent. Legs moderate; spurs of posterior tibiæ very small, subequal, and abont as long as the exterior spinules of the terminal fimbria ; the corresponding tarsi rather slender, nearly three-fourths as long as the tibie, with the basal joint one-half as long as the seconrl. Length $1.5 \mathrm{~mm}$.

\section{California (Santa Cruz Co.).}

The metasternal process in this species is rather broad, reticulate but not distinctly punctate, the merosternum transversely, moderately prominent in front of it, the prosternal process strongly dilated and broadly rounded at apex, the spinules rather close and very stout, distinctly shorter than in apicalis, but rather longer than in attenuatus, in this respect approaching the second of the arbitrary groups into which I have divided the genus.

The type of LeConte seems to be an unusually robust specimen, and I have several which are ditinetly narrower. The under surface and antennæ are sometimes paler from immaturity.

S. nanulus n. sp.-Narrowly and evenly elliptical, strongly convex, highly polished, piceous-black throughout above; legs, antenne and under surface testaceons. Head withont trace of punctuation or reticulation; antenne rather short, the funicle very slender, the onter joints more robust, club rather large and compact, the ninth joint lut very slightly longer than the tenth, the eleventh ahmost as long as the two precerling torrether, although moderate in length. Prothorar inpmetate and not at all reticulate. the merlian basal lobe hroally arcuate and rather well dereloped, the marginal bead obso. lete. Scutellum small, ogival, about two-thirds wirler than long. Elytra highly polished, without trace of retionlation except mear the apex and narrowly along the sides, where it is very feelde and not at all distinct; discal stria strongly impressed, totally impunctate, obsolete at basal third; punctures of the discal series completely obsolete and only represented ly the minute hairs, except abruptly, very near the sides, where they become dilated, distinct and cres- 
centiform, although not at all deeply inpressed. Abdomen somewhat coarsely and demsely, asperately punctate, and very coarsely pubescent. Legs very short and somewhat robust; the posterior tibixe more strongly arenate within, strongly setose, nearly spinnlose exterually; spurs very small, slender, unequal; the corresponding tarsi four-fifths as long as the tibire, one-half longer than the anterior, with the first joint about two-thirds as long as the second. Length 1.0-1.2 mm.

New Mexico (Albuquerque). Mr. H. F. Wickham.

The metasternal process is short and very broad, coarsely reticulate, but with the lines very feeble, truncate at apex, very sparsely pubescent, the mesosternum before it moderate in length, not very tumid, pubescent at the sides only. The prosternal process is broad, the terminal setose spines long and conspicuous.

This is the most minute species known to me within our faunal limits, and is so distinct in all its characters that it cannot be mistaken for any other.

S. pusillus Lec.-l'roc. Ac. l'liil., 1856, p. 17.-Oval, slightly attenuate hehind from anterior third, strongly convex, piceons-black throughout above, pale testacens beneath, strongly shining. Head very minutely, feebly punetate, not reticulate; eyes rather large; antemne moderate, third joint clavate, nearly as long as the next two together, outer joints of funicle but slightly more robust, seventh much longer than the eighth, the latter strongly transverse, club rather long and slender, the ninth joint longer than wide, longer than the tenth and much shorter than the eleventh. Prothorax excessively minutely and feebly punctate, not at all reticulate; basal lobe extremely feeble, hroad, the marginal bead alnost obsolete. Scutellum one-half wider than long. Elytre finely and distinctly reticulate in wavy broken transverse lines: discal stria obsolete at basal third, rather deeply impressed, punctate anteriorly ; surface with rows of punctures of which the two nearest the suture are very distinct, bnt obsolete in basal and apical third, rather deeply impressed and very narrowly but strongly crescentiform; the rows thence to the sides composed of more minute and very feeble punctures, which are not larger or more distinct, and rather more confused near the sides, except a regular series just within the extreme lateral bead which is composed of slightly larger, more chosely placed and feebly dilated punctures. Aldomen very sparsely, feebly punctate and pubescent. Legs slender; posterior tibia slightly wider at apical third than at apex, spinose, especially externally; terminal spurs minute, the tarsi slender, with the basal joint rather more than one-half as long as the second Length 1.1-1.3 mm.

Florida; Texas (Galveston).

The post-coxal portion of the mesosternum is indefinitely limited and angulate behind; the metasternum is very strongly reticulate, and rather densely and distinctly punctate and pubescent in the 
middle posteriorly; the process is wide, short, much smoother, very sparsely pubescent and not distinctly punctate; the mesosternum in front of it very short and feelly tumid, not at all conspicuous. The prosternal process is very strongly dilated at apex, the setose spines unusually long.

This minute species is abuudant and wirlely distributed thronghout the Gulf States.

S. modestus 11. sp. - Somewhat broadly oval, very feebly narrowed behint the prothorax, polishel, rather dark brownish-testaceous above, the leags, antemure and nuder surface pale flavo-testaceous. Hend extremely obsoletely and sparsely punctate, not at all reticulate; eyes moderate; antemie rather slender, thind joint nearly as long as the next two together, the fourth sherter than the fifth, seventh longer than the eighth, the latter slightly transverse, club rather slender and compact, ninth joint but sliglitly fonger than the tenth, and but slightly more than one-half as hong as the eleventh. Prothome nearly as in pusillus. Scutellum two-thirds wider than long. Elytre finely and distinctly reticulate thronghout in transversely wary broken lines; discal stria strongly impressed, functate anteriorly, obsolete at basal third, the punctures of the two rows nearest the suture very strongly inpressed, but obsolete in basal and apical third, the punctures of the remaining rows thence to the lateral margins very feeble lout broul and distinctly crescentiform, beroming broader in the lateral rows. Alulomen shining, sparsely, coarsely puhescent, much more densely so toward the middle and apex. Legs rather slender, moderate in length: posterior tibia rather wirler at apieal third than at apex, having series of spinose sete, more evident along the external edge; terminal spors very small, slightly merfual; the corresponding tarsi very slemter, but sliglitly shorter than the tibia, with the basal joint fully one-half as long as the second. Length $1.3-1.5 \mathrm{~mm}$.

Texas (Austin).

The post-coxal portion of the mesosternum is not at all defined posteriorly; the metasternal process is short and hroak, densely pubescent, the mesosternum in front of it rather loug, fecbly tumid, scabrous and rather densely, coarsely pubeseent; the prosternal process is very abruptly, strongly dilated at apex, the terminal setre very long and conspicuous.

The nature of the elytral punctuation, especially in the lateral series, the larger size, paler coloration, and more prominent nesosternum will readily distinguish this species from pusillus, to which it is otherwise elosely allied. It was taken in considerable abundance.

S. subalutaceus n. sp.-Almost evenly oval, fully two-thirds longer than wide, strongly convex, molerately shining, piceons-black throughout 
alove; legs, antenne and under surface dark testaceons. Head finely and strongly reticulate, the reticulations ronnded and not tending in the least to a linear arrangement; antenne moderate, coarsely setose, fourth joint shorter than the fifth, club rather robust, molerate in length, the eleventh joint but slightly longer than the ninth. Prothorer more than twice as wide as long; base transverse, without a median lobe lut slightly sinnate for a short distance each sile of the scutellum; hear very minute; surface not visibly punctate, finely reticulate, the reticnlations tending to a transverse arrangement." Scutellum ogival, nearly twice as wide as long, transversely reticulate. Elytra finely and very strongly reticulate over the entire surface, the reticulations temling to form very broken transverse wavy lines; punctures of the series almost completely obsolete although perceptible, scarcely more visible at the sires, where they become slightly wider but not at all crescentiform: discal stria feeble, coincident with the suture at the apex, very short, disappearing in a row of feeble punctures at alwut the millle. Aludomen strongly reticulate, sparsely, finely punctate, rery sparsely pubescent. Leys moderate, tibiæ smoler ; posterior spurs small, subectual, the corresponding tarsi about twothirls as long as the tibie, with the basal joint more than one-half as long as the secont. Length $1.4 \mathrm{~mm}$.

\section{Niw Jeriey (Cape May).}

The metasternal process is very wirle, broadly rounded at apex, the mesosternum in front of it rather short, transverse and but rery slimhty tumid; the prosternal process is wide, and the spinules along its apical margin very short and widely distant. The surface of the metasternum in the mildle anteriorly is extremely sparsely pulescent, and not visibly punctate.

The dark color and sternal structure will at once distingnish this small species from mitidus, which it somewhat resembles in elytral sculpture and punctuation, and the short very feeble discal stria separates it from every other species of the genus known to me. It appears, howerer, to resemble the Mexican Otibrus porrectus Sharp, which is almost certainly not an Olibrus.

S. convergens n. sp.- Somewhat narrowly oval, very courex, polished, dark mototestaceons thronghout, distinctly attenuate behind from the base of the clytra, the apex narrowly subtruneate and abont one-half as wide as the basis. Itred finely but rather distinctly punctate, more densely so toward the eyes and base, not at all reticulate; antenne molerate in length, thirl joint rather shorter than the next two together, fourth shorter than the fifth, seventh and eighth snbequal in length, more robust, club very long and strongly developerl, ninth and tenth joints equal in length, more acutely angular on the anterior side which is more densely pulsescent, eleventh nearly as long as the two preceding. Prothorax rather long, not more than twice as wide as long, highly polished, not reticulate, very minutely and rather sparsely punctate; 
lasal lobe very feeble, the marginal lead obsolete. Sentellum very short and hroal. more than twice as wikle as long. Elyto excesively minutely and feethy strigilate, having series of very minute simple pumetures which, abruptly, near the sills, become strongly transverse, confused and feebly crescentiform, the senfpture also becoming more granulato-reticulate; diseal stria dreply inpressem, obsolete at hasal thirl. Abdomen sparsely, coarsely pubescent, the transversows near the apices of the segments almost spinose. Legs momerate in length, rather robust; spmrs of posterior tibire slingtly robust, numlerate in length, and very slightly mequal; posterior tarsi rather robust, the third joint rather strongly dikated and bilobed, first joint about tro-thimls as long as the second, the latter spinose beneath and longer than the fifth which is very slender. Lengtli $2.0 \mathrm{~mm}$.

Floricla, Mr. Schwarz.

The metasternal proce-s is rery broad and rather long, adrancing almost to the anterior limits of the coxa, subtruncate at apex with the lateral beaded margin very wide, the surface polished, and alnost completely impunctate and glahrous, the mesosternum before it rory short, flighty tmmid, glabrous in the mitdle but scabrous and setose at the lateral angles. The prosternal process jobroad, dilated at apex, having a fine strong beaded marein throughout the sides and apex, the sote of the transverse apical series very short hut numerous.

This is a decidedly aberrant species, especially in tarsal structure. It is aloo peculiar in having the small forese at the sides of the hear near the eyes quite as well cleveloped as in Phalacrus.

S. attemuatus n. sp.-Narrowly ovoirlal, convex; sides of the elytra gralually convergent from base to apex, the latter narrowly rom desl ; lark rufo-testaceous throughont, ] wished. Ifead very strongly retractile, polished, not reticnlate, very minutely and sparsely punctate; antemne nearly as in cmergens, the club rather more slender and more symmetrical. Potherar not more than twice as wide as long, the sides rather fethly arenate; hasal lobe ahost conpletely wanting, the marginal bead nearly obsolete; surface not leticulate, excessively finely. feebly and very sparsely punctate. Scutellum very short, twice as wille as long. Elytre excessively minntely strigilate in transcerse wavy lines which are olsolete toward suture and base; liseal stria distinct, ohsolete at basal third; punctures of the series equal throughon the width from the suture to the sides, deeply impressed, narrowly and strongly crescentiform and distinet, except near the base and toward apex where they become nearly olsolete; intervals each with a single more irregular series of very feeble and much smaller punctures of the same general character, the series mot confused near the sides. Aldomen finely reticulate, sparsely, coarsely pubescent. Legs somew hat robmst ; posterior tibia more arenate within, rapully narrowed towarl base; spurs rery small, slightly unequal; tarsi slightly robust, basal joint two-thirds as long as the second. Length $1.6 \mathrm{~mm}$. 
New York; Michigan; Texas.

The head is strongly retracted within the prothorax in each of the single representatives of the above localities. The motasternal process is rather narrow, short, strongly rounded at apex, and strongly beaded at the sides, the mesosternum in front of it unusually loug but almost perfectly flat and not setose, except very sparsely at the sides. Prosternal proeess rather wide, extending rather further than nsual beyoud the coxe, with the free erlge strongly, transversely arcuate, and rery acute; the process is rery minutely headed at the sides, but not at all at apex, where the setiform spinules are short, erect and rery widely spaced.

This speeses is quite as aberant as convergens, but does not at all rescmble it in the strueture of the sterna. The post-coxal portion of the mesosternum is not as long as in some other species, but is very clearly and abruptly limited throughout by an evenly arenate declirous line. The terminal setie of the prosternal process are not quite as short as in comvergens, but are very much more widely spaced, being only about four in number.

S. elongatulus n. sp. - Subelongate, convex, polished, black ahove, the elytra gradually slightly paler at apex; under surface pale, rufo-testaceous thronghont; sirles feebly convercent behind from the base of the elytra. IIterd retractile, feelly convex, rather closely lut extremely finely punctate; snrface not reticulate; eyes rather large; antenne slender, the club slemier, somewhat compat, attenuate toward base, the ninth joint rather longer than wide, longer and narrower than the tenth, eleventl ahout as long as the two preceding. Prothorax rather elongate, scarcely twice as wide as long; sides evenly, distinctly arcuate; surface polisherl, not at all reticulate, excessively minutely punctate, the punctures not very sparse; hasal lobe extremely feeble, the bead fine but distinct near the midile, olsolete laterally. Scutellum small, nearly twice as wide as long, angulate; sides straight, abruptly arcuate near the base. Elytia rather distinctly more than twice as long as the prothorax ; sides nearly straight toward hase, together somewhat narrowly rounded behind; basal stria fine, reflexed along the sentellum, the single discal stria very coarse and deeply inpressed, beconing gradually feebler and punctate toward lase: disk coarsely and strongly reticulate in well-defined transverse wavy lines, the senlpture becoming abruptly almost obsolete near the base, having rather distant rows of coarse deeply-impressed rounded punctures, which are scarcely perceptibly stronger towarl the suture, the rows not attaining the base and becoming gradually obsolete toward the apex, the punctures of the lateral rows distinct but not dilated, the rows not accompanied by impressed lines. Length $1.3 \mathrm{~mm}$. 
Florida (Tampa). Mr. Schwarz.

The strueture of the under surface agrees quite closely with that of attemuatus, to which this species is most unduestionably allied, but from which it is abundantly distinet in size, coloration, and punctuation, the punctures of the elytral series being mucl less widely spaced and more numcrous.

\section{LTTOCHRUS kirichs.}

This genus, and the two which follow, are distinguished from all the others of the family by an ahrupt and very ratical difference in the structure of the posterior tarsi, for here, insteal of the hasal joint being very much shorter than the second, it in corresponding]y longer, and in the present genus is extremely developed.

The four species which are assigned below to Litochrns, possess the following assemblage of characters, pulchellus being assumed as the type:-

Ligula short, hroad, with a small median tooth at apex, the paraglossee large, dilated, semimembranons, rather thick and slightly retlexed. Labial palpi very short and robust, first joint minute, triangular; second oblique, short, slightly longer than the first, strongly transverse; third longer than the two preceding together, extremely robust, subquadrate, slightly longer than wide, strongly compressed and hroadly, transversely truncate at apex. Prosternal process inflexed at apex, not setose. Mesostermm in front of the metasternal process very short and transverse, not prominent, forming a fine undilated bead behind the middle coxie. Netasternal process rather bong and wide. Posterior tibie and tursi very slender, the first joint of the latter mneh longer than the entire remainder ; tibial spors well developed, slender.

The true Litochrus of Erithron agrees with this, according to description, in the structure of the ligula, but differs sreatly in the labial palpi, ${ }^{1}$ and the species here assigned to it may posithly have to be separated. 'The fact that widely different localities have been assigned to the genus by its author, renders it almost certain that sereral genera have been confounded, more especially as we know now that there are several distinct genera with elongate basal joint

I The labial palpi are described by Erichson as having the first joint long, somewhat longer than the second, the third elongate-ovoidal, which is much more true of either Litochropus or Oehrolitus, than it is of the Anrerican species of Litochrus. This is, however, a natter which cannot be satisfactorily settled until the entire family is monographically revised. 
in North America alone. The original description prohably refers to either the Madagascan, New Holland or Tasmanian representatives.

Our four species may be easily separated as follows:-

Castaneous; elytra each with two large oblique spots of pale flavate.

pulcheilus

Piceous-blark; elytral snture, lateral and apical margins, and a transierse

band at hasal third paler, rufo-testaceous.

crucigerus

Piceous abore throughout, the suture sometimes very narrowly, incletinitely and feelly rufescent

iun inalatus

Intense black thronghout above.

aterinus

L. pulhellus Lec.-Proc. Ac. Phil., 1856, p. 17.-Evenly and not very liroally oval, moderately convex, dark brownish-testaceous, the elytra each with two ohlique pale flavate spots, one near the base and the other near the apex, the latter the larger, neither attaining the sutme or the lateral margin, the anterior extending from near the limmeri to anterior third, and slightly sinuous; morer surface thronghont pale Havate. Head polished, extremely minutely aud rather sparsely punctate; eyes large; antenne slemler, onter joints of funicle slightly more robust and slightly transverse, thich not as long as the next two combined, club slender, as long as the seven precerling joints, eleventh distinctly longer than the two preceding together. Prothortar short, mnch more than twice as wide as long, polished, not reticulate, very finely, molerately sparsely punctate; basal lobe wilw, abrupt, short hut very distinct, the apex transverse; marginal beal obsolete. Scutellmm angulate, slightly wider than long; sides feebly arcuate. Flytro very minntely hut distinctly strigilate in transverse wavy lines througlout, having series of vory wile feelle and feehly crescentiform punctures, which become wider near the sides where the series are still regular; intervals near the sides with single regular series of very small punctures of similar nature, which, toward the sutnre, become much nore minnte and feeble, and confusedly dispersed over the pntire interval, especially between the discal strice; the latter fine but distinct, obsolete at basal third or fourth, the first continnons to the apex, the secoud coincident with the first at apical fifth; sutural bead obsolete, except toward apex, where it is excessively fine, feeble and just traceable. Legs very slender; posterior tibial spurs slender, long and distinet, slightly unequal, the tarsi extremely slender, cylindrical, the first joint fully one-third longer than the entile remainder. Length $1.1-1.7 \mathrm{~mm}$.

Florida; 'Texas.

The metasternal process is wide, and extends to the anterior limits of the coxe, the mesosternum before it being very short and transverse, and not at all prominent; the prosternal process is rather wide and feebly dilated at the inflexed apex.

L. crucigerus n. sp.-Narrowly, almost evenly elliptical, strongly convex, polished, piceous-black, the suture and lateral and apical margins 
narrowly, and a transverse line crossing the suture at basal third paler, rufo-testaceons, the pale areas not very abruptly limited ; under surfice pale flavo-testaceons. Ifend and antenne nearly as in the preceding speries, the forner more sparsely and muevenly punctate. Prothorar, sentellum and strigilation of the elytra nearly as in immonlutus, the former slightly more sparsely punctate. Elytu having rows of extremely wile crescentiform punctures, nearly as in the preceding species, hut rather more strongly impresised, the punctures of the intervals very small but distinct towarl the suture, leteoming almost obsolete laterally; two discal strice distinct, olsolete at basal third. Legs, tarsi and sternal structure nearly as in puldellus. Length $1.5 \mathrm{~mm}$.

Florida. Mr. Schwarz.

This species differs conspicuously from the others in eoloration, but the structural characters are nearly alike in all of them, the punctures in general, and esperially the rery strongly transverse crescentic pinctures of the elytra, are, however, decidedly most distinct in the present species.

L. immaculatus n. sl. (Zimm. MS.)--Narrowly and almost evenly oval. strongly convex, pristherl upper surface dark piceous, the suture fielly rufercent; unter surfice throughont pale flavo-testaceons. Heal not reticulate, polished, tinely but rather distinctly punctate, the punctures broakly, fecbly inpressed; eyes rather large: antenne nearly as in pulchellus. Prothorux muclu more than twice as wide as long, polished, not reticulate, the basal lobe abrupt, short, listinct, truncate, the marginal bead obsolete; punctures sparse, very fine but somewhat distinct, hroally, very feehly impressed. Scutellum nearly twice as wile as long; silles strongly arcuate toward hase, straight near the apex; angle not appreciably romiled. Elyticu finely, transversely strigilate in wary lines; sutural bearl, discal strixe aud punctures of the principal series nearly as in pulchellus, the punctures of the intervals excessively minute and feeble, am almost obsolete even toward the sides. Aldomen shining, coarsely reticulate, the lines very fine, very sparsely pubescent. Legs slenter; posterior tarsi extremely slender, the first joint much longer than the entire remainder. Length $1.5 \mathrm{~mm}$.

\section{New Jersey ; South Carolina.}

The metasternum is shining, coarsely reticulate, the lines very fine; surface very sparsely pubescent, almost impunctate except posteriorly toward the midlle, where the punctures are fine and subasperate; process broad, extending to the anterior linits of the coxie, feebly constricted near the apex, the latter broally, frebly arenate, the mesosternum before it extremely short, transverse, fincly setose, not prominent; the prosternal process is moderate in width.

This species is more narrowly oval and convex than pulchellus, and is very differently colored. 
L. Aterrimus n. $s$. - Oval, about two-thirds longer than wide, strongly convex; sides very fexbly convergent behind from near the base of the rlytra: intense l, lack throughnut above, paler, piecons beneath, the legs and antenuat flavate; shining. Heerl not reticulate, very minutely and rather sparsely punctate: eyes moderate; antennat rather short, third joint elongate, obconical, rather longer than the next two, four to eight very short, compact; club small and slender, alout as long as the preceding seven joints combined, ninth just visibly longer and wider than the tenth, eleventh oval, a very little longer than wille, shorter than the two precenling. Prothorex rather short, more than twice as wirle as long, extremeiy minutely and obsoletely punctate, not at all reticulate, the basal lole broad and rather strong, the marginal bead almost completely obsolete. Scutellum triangular, two-thirds wider than long. Elytre rather more than three times as long as the prothorax, evenly and somewhat narrowly romded at the apex; discal striat very time, vanishing at hasal third. the first continuous to the apex, the second approaching very near but not joining the first at apical fifth or sixth : disk coarsely reticulate in very way broken lins, having distant regular rows of small widely-spaced erescentiform and very faphle punctures, which beeme slightly wider and stronger near the siles, the punctures of the intervals almost completely obsolete. Legs moderate; posterior tibix very slender, cylimlrical, the terminal spurs very unequal and rather long, the corresponding tarsi very slender and cylindrical. the first joint just visibly longer than the remainder. Length $1.2 \mathrm{~mm}$.

Florida (Biscayne Bay). Mr. Schwarz.

Remarkably distinct in its intense black color and feeble puncetures. The eves are, as mual, very coarsely faceted, the facets, however, musually convex, especially beneath. The metastemal process is wide and long, extending slightly beyond the coxe, the apex feobly arcuate, the sides parallel, very fincly beaded and not at all inturvate: the mesosternum forms a very thick and eren apical head. In crucigerus and immaculatus the metasternal process is narrower, the sides being distinctly, although feebly, incurvate.

LITOCHROPUs n. gen.

Nentum slightly wider than long, transversely truncate at apex, the sides strongly lobed just lw fore the middle. Ligula small, uarrow and rather short, deeply and distinctly sinuate in the middle at apex, not at all dentate, the paraglosse very small and nearly olsolete. Labial palpi moderate; first joint slightly longer than wide, distinct, lut much shorter and narrower than the second, the latter teebly obenical ; third not strengly compressed, but slightly wider than the seemd, oblique, dilated toward base, attenuate toward apex, as long as the two preceding combined. Maxillary palpi well developed: second and third joints oblicuely truncate at apex, the latter shorter and not as long as wide; fourth slightly longer than the preceding three together, not wider than the second, cylindrical in the hasal half, feebly narrowed toward 
apex in the apical half. Antenna with the club very long and finely, asperately punctate thronghont. Prosternal process momerate in wilth, the a pex inflexed and unarmed metasternal process rather wide, with the sides paraldel, rather long, extending fully to the anterior limits of the coxie, broally, evenly rommled at apex. Hesosternum in front of the netasternal process forming a wry thick, strongly prominent, feebly seabrous aml minutely setese marninal bearl, which becones fine along the inner side of the coxie, and is dilated behind the middle acetabula as in Aeglomms. Legs slender; posterior tarsi very slender, cylindrical, nearly as in Litochrus, but with the first joint searcely four-fifths as long as the entire remainder; posterior tibial spurs moderate, very slender, decichly unequal.

In the structure of the ligula, labial palpi, ant the extension of the mesosternum behind the millle acetabula, this genus differs rery greatly from those species which we consider Litochrus and represented by pulchellus as a type; the basal joint of the posterior tarsi is also distinctly shorter, and the third joint of the latter is rery obliquely truncate at apex, the fourth with its ill-defined basal lobe being inserted at the middle of the truncation.

L. scalptus n. sp.-Rather hroadly oval, piceous-black throughout above; under surface, legs and antenuxe very pale flavate; polisherl. /leud finely, sparsely but rather listinctly punctate; eyes musmally small; antema mbust, the chu almost as long as the entire remaimler, third joint fully as long as the next two together, onter joints of funicle robust and transverse, ninth and tenth subequal in length, eleventh as long as the two preceding. Proflemar very feebly, sparsely and obsoletely punetate, polishert; basal lobe as in Litochrus hut more feeble; marginal bead obsolete. Scutellum ogival, nearly twice as wide as long. Elytra entirely polished, withont trace of fine sculpture, having series of long tine transverse seratehes, the punctures entirely obsolete, although each of the fine lines has a very mimute recumbent hair in the midlle, the lines feebler toward base and apex, the series so close that the transverse lines are sometines continuous laterally; sutural hear subapieal, excessively tine; diseal stria obsolete at basal third, distinct, the first continuous to the apex, the second coineident with the first at apieal fourth. Abdomen tinely, feebly reticulate, sparsely, coarsely pubescent. Legs nolerate in length. Length 1.5-1.7 1mm.

\section{North Carolina; District of Columbia.}

The posterior tibix, in the males, are slightly more robust than in the females, but there does not seem to be any dereided sexual difference in the terminal spurs or tarsi.

The renarkable transverse scratches, which are an extreme morification of the ordinary type of transversely crescentic punctures, are peculiar to Litochropus and Ochrolitus, and it is prohable that Litochrus globulus Sharp, should be assigned to the present genus. 


\section{ochiroLites Sliarp.}

This genus is well distinguished from either of those which precede by the structure of the prosternal process, which is here more developed, projecting beyond the anterior coxa, having the apex free, with an acute elge which is transversely arcuate.

The two species described below differ generically. I did not receive the tyje of tristriatus until a time subsequent to the printing of the table of genera, given on page 91, and had previonsly regarded rubens as a typical form of the genus; it is therefore underirable, at prosent, to ereate a new genus for the latter species, although this must be done when the family is monographically rerised. The species are very easily distinguishable as follows:-

Prosternal process moderate in wilth, feebly, longitndinally convex, extending but slightly beyond the coxie, the apex moderately dilated, very feebly arenate, nuarmed. Nesosternum mot developed behind the midlle acetalula. First joint of the posterior tarsi much longer than the next two combined. Discal striae three in number

tristriatus

Prosterual process wider and longer, projecting distinctly leyond the eoxe, flat, spatulifom, the apex very strongly romded and bearing a series of five or six long spinose setre. Mesosternum developed as a short arenate plate behind the middle acetabula. Basal joint of the posterior tarsi shorter, subequal in length to the mext two together. Diseal strice two in number.

rubens

O. tristriatus n. sp.-Oval, very convex, rather more than one-hali longer than wille, willest near the base of the elytra, the silles thence very feebly comvergent behind; npler surface shining, dark piceo-rufins, the elytra slightly opalescent; beneath paler, rufo-testaceous. Ited not reticulate, very finely but distinctly and rather densely punctate; eyes moderate; antenne long and well developed, second joint small. much shorter than the third, the latter equal in length to the fourth and lint slightly longer than the fifth, eirluth but slightly wider than the seventh, scarcely as wide as long; club nearly symmetrical, rather loose, as long as the five preceding joints conbined, ninth joint very slightly longer than the tenth and fully two-thirds as long as the eleventh. Prothorac large, but slightly more than twiec as wide as long, the base very feebly incurvate between the hasal angles, the hasal lobe rather wile but excossively feeble, the bearl completely obsolete; surfice mut reticnlate, extremely minutely and moderately sparsely punetate, the fine hairs unusually long and distinct. Sentellum triangular, nearly twice als wide as long. Elytra searcely more than twice as long as the prothorax, the apex evenly, semicircularly rounded, excessively minutely and densely strigilate, the lines not resolvable under a power of so, having long transverse very distinct, and anastomosing scratches, from which arise the tine but rather 
distinct hairs, the latter not being cery definitely arranged ; each elytron with three distinct discal stria, vanishing at about basal thiml, and converping toward the apex, the onter two slightly abbreviated ; sutural beald fiue, lut distimet towarel the alex. Leys ratler robust; posterior tibia rylimbical, narrowed in basal third, almost transversely trmmeate, the sjoms long and very unerpal, the rorresponding tarsi long, eylinhical, the hasal joint ouethird longer than the next two together. Mutastemum warsely and strongly punctate toward the midlle. longth $2.1 \mathrm{~mm}$.

Florisla (Key West). Mr. Schwarz.

The metasternal process is narrow and rather short, the mesosternum before it forming a rather bong gratually declivous piece, feebly enveloping the coxe at the sides, - almost exactly as in litolibrus-and not developed behind the middle acetabula, except as a tine marginal bead. The prosternal process is finely beated at the sides but not at the free acute and feebly arcuate apex, the latter being also devoid of true spinose seta.

There ran be but little doubt that this species is a complete representative of Ochrolitus, but it is also certain, on comparison with the carefully drawn figure of $O$. optentus Sharp, that it cammot be identical with that species. In the present form the transverse scratehes are very strong and extend throughout the elytral disk, except rery near the base.

O. pubens Lee.-Proc. Ac. Phil., 1856, p. 16.-Evenly, moderately broally oval, strongly convex, polished, bright rufous throughout ahove and hemeath. Hod finely, sparsely punotate, polished; eyes molerate; antemne molerate, funicle rather slender, onter joints slightly robenst, the eiglith decidedly wider and rather strongly transverse, third as long as the fourth and tifth, the latter equal, louger than wide, chob robust, molerate in length, nearly symurtrical, ninth and tenth joints nearly etinal in length, the eleventh as long as the two precerting combined. Prothorer rather long, but slightly more than twice as wirle as long, polished, almost completely impunctate; basal lohe excessively feeluse, unt abroptly limites, the marginal leear obsolete. Scotellum suall, ogival, willer than long. Elytien excessively minutely, transversely strigilate in way lines toward apex only, covered throughont except towand hase with very dees long transverse scratches, which are sometimes broally angulate at the minute hairs, the punctures rather distinct near the suture; discal strice strong, olsolete at basal fifth or sixth, the secome coincident with the first at apical fousth. Posterior tarsi very slender, cylindrical, the hasal joint threefourths as long as the entire remainder; tibial spurs well developed, meernal. Length $1.8 \mathrm{~mm}$.

North Carolina; Florida.

This is a rely distinct species which appears to be rather rare: 
I have seren there speciusens. The setar of the prosternal process are met ereet as in the stillide genera, but perfectly porrected. The motastrernal process is rather lome, moterate in wilth, projecting anome to the anterior limits of the coxe, the apex trumeate, the mesuscrmm before it abruptly derdivous and not in the least Irominent.

\section{CORYLOPHIID.E.}

\section{RENGMA'TCUM Matth.}

This singular gemus was desepibed by me from some Californian -pecimens, before the alperatrace of Mr. Matthews deseription in the biobogia centrali-Amerieana, hut $I$ was somewhat at a loss where to place it, hesitating between the corylophide and Latridiidal.

The following species oecurs in grrat ahumbanee near San Fran(eiseo, in moist places among lle roots of grasies, and I have also -haken it from small shrubs in the vieinity of Oakland.

A. califormicum n. sp.-Form rather slemere, dark pienous-brown,

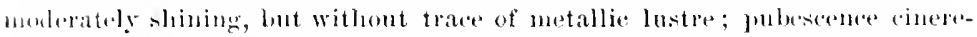
oms. Hered small, subtriangular ; eyes rather large, at the base, conrex,

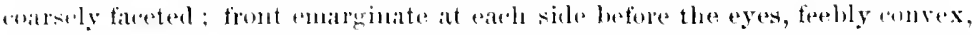

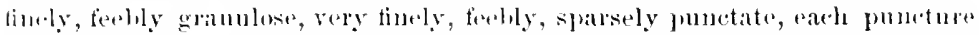
heariug at suall sulveedumbent hair. Protherer two and one-hall times as wide

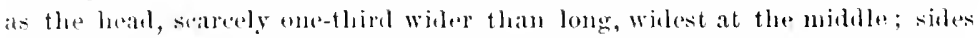
lonally, erenly rommled in the apical half, foelly convergent, straight and feelly. minutely serrulate lleenee to the hasal angles, which are slightly ohtuse

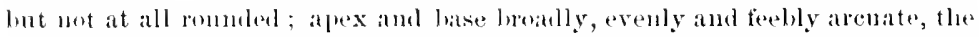
latter distimbly the wiler, disk teebly, arenly convex, timely subgramulese, stightly alutacens, rather coarsely, Ineply, but somewhat sparsely punctate, limely sarsely pubesent. Sentellum moderate, very strongly transiorsen, smooth atud polished. Elytar one-tifth lomger than wide, widest near the midelle, one-tith wider and twe-thirds longer than the frotlowax; sides linally ancuate: apex angularly antroinate, exterior angles romuled ; disk

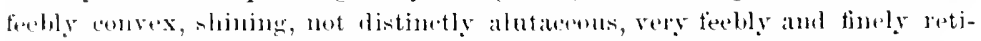
culate, fimely, feobly and sparsely punctate; pumetures rather obsolete, not arranged in well-detined order; phbescente very tine and sparse. Leys, antemua and under surfice, extept the athlomen, much palere, brownish-testaarons, the latter piceous-blitek. Lemgth $0.8-11.9 \mathrm{~mm}$.

('alifornia (san Mateo and Alameda ('os.).

Differs from the Contral Ameriean ptilioides Matth. in its larger size, more clongate frothorax, and shining clytra and seutellum. 
The fifth antennal joint in ptilinides is representerl on the plate as

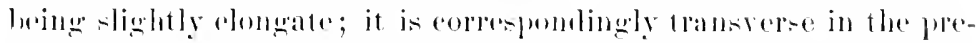
sent speries, and the joint immerliately before the club is strongly

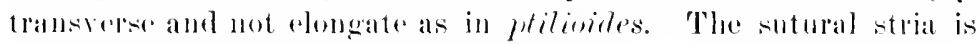
feeble atud continuous with the basal stria.'

\section{BYRRIIII.E.}

\section{LIMNICIUS Latr.}

The species of this genns, althongh hut moderately munerous in the l'nited states, appear to be mueh more alundatit and diversifier in structure than the ir European congeners. Our species have never been fully described, and have heen somewhat negleeted by rytrmatists. The tahle given by Leconte (Bull. U. S. Geol. Surv. $V$, p. 515), bears eviflence of insullicient observation, and I have not found it of very great serviee in identifying the spereses, which in reality are well differentiated. They may be dividerl as follows iuto four sulgenerie groups, which are perhaps of still greater value. These groups are all distinet from the representatives of the palararetic fatma, there being generally no trace whatever of the antemnal groore on the superior surface of the bead which is such a singular character of Limnichus proper. In all of our sulygenera the antennace

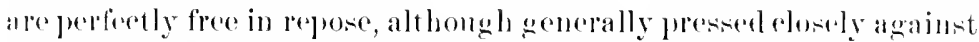
the head, and between its surface and the projecting anterior matroin of the prothorax. In the tirst gromp (Euliminichus), the last vestige of the eroove is visible, being indirated by a minute calrina berteringre the silles of the head above the eye, but it ean be of no wee as a shelter for the antemne in repose:-

lubusconce in a single system, rather sparsely distributed, subrecumbent, rolust ant aciculate.

Heal longitudinally rugulose; hasal joint of anteune in great part concealerl by the acute sicles of the front, the emarginations at the extrenities of the epistomal suture small. Prostermum growed; hypounera 1lat, not impresised at the inmer angle, having a wicle prominent polisherl beal alomg the inner matrgin; margin of the crural excavalion arote and cariniform; acute onter enlge minutely and aboutly roflexid at alex.

I Dr. Sharp, who has been kimb enotgh to compare a slectumen of this speedes with the type of ptilimes in the British Musimm, writes me that, allhough the light at the time was very poor, lae has no doult of the listinctuess of californicum.

Axsas N. Y. ACan, Scl., V, Feb. 1890.-10 
Srutellum distinct, much longer than wide. Elytral punctures genelally distinct, always well separated .......................................

Hear coarsuly, very densely punctate, without trace of lougitndinal rugnlation: Jrasal joint of antenne in great part exposed in the large desp emarginations at the extremities of the pristomal suture. Prosternm groovel; lypomera Fery deeply inprossed near the imel olotuse angles; inner polisherl beasl well developed ; craral margin acute and cariniform; acute outer elge very gradually, feelly sinuate towaril the apex. Scutellun molerate, sliglitly longer than wide. Elytral punctures generally coarse and densely placel, cribrate

llear finely, feebly junctate, finely granulose; hasal joint of antenuse in great lart exposer, the enarginations large. Prosternum not groover ; hypunera tlat, not impressed, withont trace of an inner polished hear, the crural margin roumled, not distinctly and abuptly defined by an acute enge, the acute onter edge dellexed at ajex. Scutellum large, equilatero-triangular. Elytral punctures very minute, entirely filled by the liairs. Antenne unusnally long ank slender... Pubesence dual, consisting of very small short confusedly matted and denselyplaced hairs near the surface, with fine loug erect and much more sparselyplated hairs interspersed. Scutellum very small, equilatero-triangular, or very nearly so. J'rosternum grooved. Crural edge of liypomera acute amel rariuitorm

The minute reticulation or granulation, especially visible at the sides of the pronotum and on the hypomera and abdomen of groups I, III, and IT, is totally obsolete in group II, and constitutes an important differential character of this section of the genus.

It a generic character, it should be stated that the epiplenre are, mear the apex, deeply grooved; this is more evident in the first three groups, and becomes rery feeble or nearly obsolete in group IT.

The species nray be distinguished as follows:-

\section{Group I.}

Euturichus 11 . suligen.

l'ronotum finely reticulate or grannlose and more or less alutaceous at the sides.

Elytral punctures rather coarse, deep and very distinct, suparated by from once to twice their own diameters.

Prosternal epistema almost attaining the apex analis Prosterual episterna shorter.

Abdonen very minutely, sparsely and feebly punctate, not appreciably more coarsely so near the sides; merlian groove of pronotum fine but distinct, rather long and terminating at equal distances from base and apex

Abdomen sparsely but more coarsely punctate, very coarsely and deeply so near the sides; pronotal groove very short and uearer the hase 
Elytral punctures extremely fine and sparse, separated by from three to five times their own diameters.

Elytra and abdomen alntaceous, the latter excessively feobly, minutely punctate, the punctures rery sparse, searcely visible and not appreciably more distinct laterahly ; elytral pubescence very minnte anul sparse.

nontanus

Elytra and aldomen strongly shining, the latter very minntely but rather distinctly punctate, the punctures sparse, very sliglitly larger near the apex, and less distinctly so near the sides.

perpolitus

Pronotum highly polished throughont and perfectly devoid of reticnlation at the sirles.

Punctuation of elytra denser, deeply impressed and very distinct....... ater Punctuation sparser and very feebly impressed, almost invisible near the sides and suture

nitidulus

\section{Group II.}

Linichites n. subgen.

Allomen densely, coarsely cribrate; punctures of the pronotum very dense.

Larger species, oval; siles distinctly arenate; punctures of the elytra slightly separated

punctatus

Smaller species, more oblong, with the sides nearly straight in the mithlle; punctures of the elytra larger, polygonally crowded

nebriosis

Ablomen densely, coarsely cribrate toward the sides, lut sparsely and nunch more finely punctate toward the midale aid base; punctures of the pronotum fine in the middle, sparse, those of the elytra rather fine, separated ly distinctly more than their own diameters.

ollivaceus

Alumen more sparsely punctate; punctures of the fromotum toward the middle sparse and fine; punctures of the elytra very narrowly separates.

perforatus

Group III.

Licnume's n, subgen.

Ovate, pointed behind; pubescence rather fine, recumbent, moderately dense, dark brown in color.

tenuicornis

\section{Group IV.}

LiMNichoneri's n. subgen.

Aldomen completely devoid of punctures; 1 each elytron with a subapical and two lateral submedian indefinite patches of paler pubescence.

naviculatus

1 In this subgenus the ablomen is always remdered more or les: dnll hy an extremely minute rugose reticulation. The punctures here referren to are entirely distinct from this : they are deep and perforate, and distributed generally somewhat unevenly over the surface. 
Aldomen vely finely and sparsely punctate.

Elytral punctures coarse, lenser, the pulsescence extremely dense ant the lustre dull

Introchinus

Elytral junctures finer, more sparse, the surface much nore shining.

Elytral pulescence very short, even; alwominal punctures visible thromghout the width, equal and very sparse throughont...

seriatus

Elytral pubescence longer and more shaggy ; ablominal punctures completely absent towarl the sides of the last three segments, very fine and sparse but visille in the mithle towaril base; aldomen rather less dull.

ovatus

Alwlowen coarsely and densely punctate, especially towart the sides, the punctures rather sparsel toward the middle; black, polished; pulescence very easily alowated, less dense.

punctiventris

\section{*}

L. alalis Lec.-Bull. U. S. Geol. Surv., 1879, V, p. 515.-Oval, strongly romelirl behind, nearly twice as long as wide, willest at the milllle, black throughout, shining; pubescence somewhat dense, moderate in lemgth, sullecumbent, evenly distributed, feebly mottled cinereons and fulvous, the hairs robust and strongly aciculate. Hearl strongly and reoply punctate; punctures longitutinally coalescent, forming fine strong somewhat interlacing ruge: lateral supraorlital ritges fine and strong. Prothorer more than twice as wide as long; sials straight, strongly narrowed from lase to apex, the latter two-thirls as wille as the former; liasal lobe strong, truncate; surfice nearly as in culfimions, the punctures slightly denser. Scutellum threefourths longer than witle, that, finely, sparsely punctate; sites and base luoally arcuate. Elytrutome times as long at the prothorax and scarcely oneformth wider ; surface shining, very olsoletely reticulate; punctures nutherate, here] hut variolate, separater by about ome and one-loalf times their own wistlss. J'rosternum shining, tinely and rery sparsely punctate, the punctures larger and nearly twice as dense anteriorly; median impressen groove strone, olsolete at anterior fith; episterna clearly limited within throughout their length, alnost absolutely attaining the apex; hypomera flat, not percentily inpressed at the inner angle, minutely, strongly retienlate, alutaceous, very finely, sparsely punctate. Alulomen rather sparsely punctate, finely, strongly granulato-reticulate laterally and toward base, the segments polished towarl apex, the fifth polished, deeply, coarsely cribrate, impressed and chensely pubescent near the apex. Length $2.3 \mathrm{~mm}$.

\section{'Texas; Arizona; California.}

The largest srecies of the genus, related somewhat to califormicns, but differing in its denser pubescence and punctuation, and in the cxtout of the prostermal side-pieces; the prothorax at base is relatively wider, the elytra at the humeri not being rather abruptly wider and somewhat prominent as in californicus. 
L. obscurus Lee.-Proc. Acar. Nat. Sei. Phila, VII, p. 116.-Evenly oral, strongly romded behind, widest near the middle, convex, shining; puhesernce sparse, fime, subrecumbent, short and molerately robust; color back throughout. Hent finely, Ingitulinaly rugulose, the roge lather feelde and confuserly interlacing, the intervals minutely granulose and fincly functate; supra-orbital carine very feeble, depressed below the genteral surface of the front. Protherer much more than twice as wide as long; sides very feebly arcuate; apex nearly three-fourths as wide as the base, the latter lroally and molerately sinuate at each sile of the median lolwe, the latter moderately prominent; snrtace minutely reticulate, feebly so in the midhle, strongly so and almost granulose laterally, rathe distinctly and sparsely fomitate. Scutellum of the usual forn. Elyfor with the siltes evenly, ferelly arcuate and perfectly coarctate with the sides of the prothorax; sculptur nearly as in montames, each puncture surrounded by a series of listinct reticulations, shining; punctures small, not deeply inpressed, separated by more than twice their own wilths. Prosternum sparsely punctate, the mentian gronse wide, deep and approaching the apical nargin to within one-sixth or one-secenth the entire length; episterma charly linites within thronghout, appoarhing the apex to within one-halt their own length, not visilly punctate; hyponera nearly fiat, tinely retindate and alntaceons throughout. very finely and sparsely punctate. Adomon tinely retienlate, finely and sparsely functate, the fifth segment impressed and densely pulpescent near the arex. Length $2.1 \mathrm{~mm}$.

New York. Cab. LeConte.

Greatly resembles montanus in ontline and scolpture, lout differing in its coarser punctuation, longer and coarser pubescence, and very much longer and wider prosternal groore. It cannot be clasied at all with ater, with which it was united by Leconte, differing in size, form, sculpture, punctuation and pubescence to a very marked degree.

L. Californicus Lec.-Bull. T. S. Geol. Surv., 1879, r. p. 515.-Elliptical, nearly trice as $l o n g$ as wide, strongly roumlext at a awex, widest at the middle, black, rather strongly shining. Herel very leeply and rather coarsely punctate, the punctures completely coalescent longitudinally, forming deep and almost regular rugse. Prothorec nearly two and one-halt times as wille as long; siles convergent from base to a pex and nearly straicht; median hasal lohe strong, truncate; disk finely granulato-reticulate, strongly so and alutaceons near the sides, rery fiebly so and prlished toward the midlle; punt nues fine and sparse throughout; median impresion foelbe only risible in the hasal half. Sentellum nearly two-thirds longer than wille, that, pointerl; sides and bise feethy arenate. Elytra nearly four tines as long as the prothorax, and, at hasal third, nearly one-third wider, polished: retieulations almost cibolete throughont; punctures impressed, moderate in size, distinct, saparatel by fully twice their own widths. Prosternum finely, very sparsely 
punctate, having a wide deeply-impressed groove which becomes obsolete at anterior third ; episterna not attaining the apex by nearly one-half their own length, clearly limited within thronghont; hypomera flat, strongly retiulate, alutaceous, finely and sparsely punctate, the inner polished marginal bead molerate in width. Aldemen tinely reticulate, shining; punctures wolerate, sparse; pubescence short, setose and sparse, the last segment flat, with a densely pubescent median area. Length 1.7-1.9 $\mathrm{mm}$.

California (Mendueino, Santa Clara and Los Angeles Cos.).

The pubescence is rather short, sparse, pale fulro-cinereous in color, robust, acutely pointed and subrecumbent. This is a very common species throughout western California.

L. montanus Lec.-Bull. L. S. Geol. Surv., T, 157?, 1. 514.-Almost evenly oral, strongly rounded at apex, a little less than twice as long as wile, back throughont, subalutaceous; pubescence very short, subrecumbent, very sparse, cinereons, apparently easily al,raded, not conspicnous. Heud with fine lougitudinal ruge, the concave interrals more minutely and feebly rugulose, amd with suall distant punctures; lateral carince fine but strong. Prothorke morethan twice as wide as long; sides very feebly arenate; apex abont twothiris as wide as the base, the basal lube strong, with the apex sinuons, fitting the base of the scutellum; surface finely granulose laterally, more polished in the middle, rather finely and sparsely punctate; median groove very fine, short. Scutellum one-half longer than wille; sides and base very distinctly areuate, the suriace very minutely and sparsely punctate. Elytic rather less than fuur times as long as the prothorax, and, at basal third, about one-fifth willer; siles very distinctly, evenly arcuate and coarctate with the silles of the prothorax; surface finely, sparsely punctate; punctures romd, shallow, not inpressed, separated by at least three times their own widths. Prosternum polished, very finely and sparsely punctate, slightly more coarsely and closely so anteriorly ; median groove narrow, very deep posteriorly, becoming more feeble anterioly and obsolete at apical fourth; episterna distinctly limited within thronghont, not attaining the apex by about one-third of their own length; hypomera that, not impressed at the inner angle, finely, strongly reticulate, alutaceous, minutely, sparsely and not distinctly punctate; inner bead strong. Alutomen very finely, densely reticulate throughont, minutely and very sparsely punctate; fifth seguent with a very suall impression just behind the apical margin, the pubescence of the central area coarse, short and not very dense. Length $2.0 \mathrm{~mm}$.

\section{Colorado (La Veta). Mr. Schwarz. Cab. LeConte.}

The sculpture of the elytra is peculiar, although merely an intensification of the normal senlpture in this section of the genus. Each puncture is surrounded by a series of six flat reticulations, the series contiwuons externally, the outer bounding lines being hexagonal. This is a remarkably distinct species. 
L. perpolitus u. sp.-Ahmost evenly elliptical, rather pointed behind, alunst twice as long as wide, black thronghont, highly polished. Heat strongly, longitudinally rugose, the intervals finely, sparsely pubescent and punctate; cariniform upper margins of the eye pronounced, the sinall dorsal forea immediately before the eye very deep. Frothorax much more than twice as wille as long; sides nearly straiglit; apex two-thirds as wide as the base, the litter strongly simmate at each side of the median bo which is well developed; surface polished, excessively obsoletely reticulate in the middle, strongly so and slightly alutaceous at the sides; median groore short, feethe, broally impressed; disk rely minntely, sparsely punctate and pulnesent. Scutellum nearly one-half longer than wide, minutely, sparsely punctate: sides and base areuate. Elytro not quite fonr times as long as the prothorax; siles very evenly and distinctly areuate and coarctate with the sides of the luthorax, the humeri not in the least prominent; surface very highly polisherl punctures very minute and feebly impressel, separated by from four to five times their own widths; pubescence very fine, short and sparse, silvery-cinereons throughont, not conspicuons. Prosternm finely, very sparsely punctate; median impressed groove nearly erual in wilth throughout, obsolete at apical fifth or sixth; episterna distinctly liniterl within throughont, amost attaining the apex; hypomera transversely, feebly convex, finely reticulate, not impressed, very finely, feebly and sparsely punctate throughout, the polished bead forming the inner margin very strong. Abdomen finely reticulate laterally towam lrase, not at all reticulate and polished at apex, finely, sparsely punctate, a small pubeseent area near the apex of the fifth segment densely and deeply punctate, not impressed but with the apical edget reflexed. Length 1.7-1.9 $\mathrm{mm}$.

'Lexas (Austin); New Mexico (Albuquerque). Mr. Wickham.

A very distinct species in its extremely minute, sparse punctuation and pubescence, and highly polished upper surface.

L. ater Lec.-Proc. Acad. Nat. Sci. Phila., VII, p. 117.-Oral, abont trothirds longer than wide, widest near the middle, ratles acutely pointed helimel, back, polisher ; pubescence coarse, rather long, subrecumbent, moderately dense, in great part fulvous. Head with fine, rather feeble, longitutinal ruga ; intervals finely punctate; pubescence abmulant, suberect. Prothorat abont two and one-half times as wide as long; sides nearly straight; apex two-thirds as wille as the base, the latter deeply sinnate at each side of the molerate median lobe; surface highly polished thronghont, withont trace of granulation or retionlation eren near the siles, rather coarsely and sparsely punctate. Scntellum one-half longer than wide. Elytre at the humeri rather abruptly lut slightly wider than the prothorax, alont four times as long as the latter, and one-fonrth wider; sides erenly arcnate; surface rather coarsely and deeply punctate, the punctures impressed and separated by nearly their own widths. Prosternm somewhat coarsely and sparsely punctite, the mertian gronve rather feehle, vanishing at apical fonth; episterna small, leeply, coarsely punctate, not clearly limited within anteriorly, and coning very far 
from attaining the apex, the distance thence leting expal to their own length ; hypenera nearly that, finely but rather feelly reticulate, polished mear the exterion marcin, rather corarely, deeply and somewlat densely punctate, thes

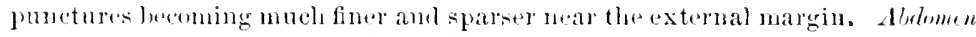
somewhat shining, rery finely and sparsely punctate; fitth segment not risibly inumessul, the puldescence fine and dense in the middle. Length $1.8 \mathrm{~mm}$.

North Carolina; Florida; Lonisiana.

This species very greatly lesmbliter californims in size and ontline, Wut differs conspienously in the pulkecence, which is mueh longer and nure robust ; is also mole coarsely and closely punetate, amb the seulpture of the promotum is very different-its stong polish, without granulation, near the sides being a rery decisive charactel.

L. Initidulus Lee-Proe. Acad. Nat. Sci. Plila., VII, p. 117.-Evenly oral, widest in the middle, nearly twice as long as wide, rather acntely pointerl

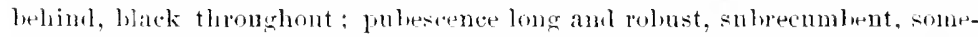
what sparse lut cousphenons. Heed with tine bongitudiual roge, rather densely puleserent : latoral ribges slightly prominent Prothorex polished throughout. not reticulate near the sides, sparsely and somewhat coarsely punctate; punetures in the millde separated ly from two to three times their own widths; median grove very slout and feetle. Scutellnm small, about one-thim longer than wille, highly golished and very minutely, feehly and sparsely punctate. Elytro not quite four times as long as the frothorax, alout one-thiril willer ; siles stromely arcuate, coaretate with the sides of the prothmax; surface polishen: punctures rather large but feshle, separated by ahont trice their own wilths. Prostermm rather sparsely punctate, coarsely so anteriorly, finely posteriorly; median groove strongly impressed, olsolete at anterior fourth ; "pistema aluptly limited within throughout, approaching the apical margin to within ome-half their own length; hypomera flat, not inpressed, finely, strongly reticulate, with a few coarse punctures near the inmer marginal beal, olsewhere tinely, sparsely punctate. Aludomen finely reticulate, finely, sparsely puleseent; punctures moderate in size, rather deeply impressed, somewhat frarse, dense on the last segment which is not impressed, and with the puldescent area not well markel. Length $1.6 \mathrm{~mm}$.

Georwia. Cab. LeConte.

A small species, remarkable for its relatively long, very coarse pubsicence, and polished surface. The punctures of the fifth rentral segurent are, as usual, rery deep and perforate.

\section{米米}

L. punctatus Lee.-Proe. Acarl. Nat. Sci. Plila., V1I, p. 116.-Oral, strungly mumled behind, about three-fourths longer than wide, widest in the middle; sides distinctly arcnate; black, densely pubescent in feeble mottling 


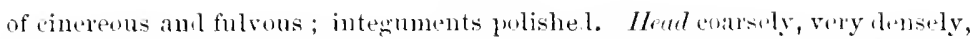

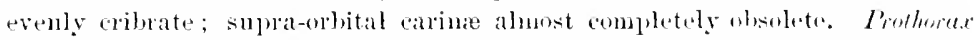
much nowe than twice as wide as long ; sides forbly, evelly arenate; alex

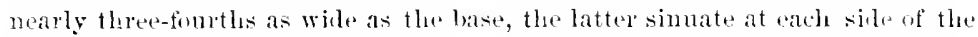
wide and prominent median lobe: surfice poljsherl, not at all wetiendate at the

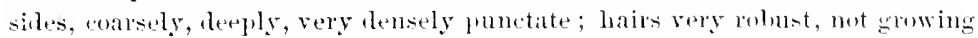
from the punctures but each attached at the margin of a foucture ; median moove finte distinct, slightly nearer the base tian the apex. Sicutellum molerate, very slightly longer than wile, perinted, densely punctate; sicles and base stromgly arcuate. Elytre about three amd ome-lialf times as long as the frothorax ame scareely one-tifth wiler; siles coaretate with those of the pothorax; surface polished, vely coarsely and densely pundate; pumctures Fery deep, pertorate amd separated ly less than one-half their uwn dianeters. Prostermun polisherl, coatsely punctate, the punetures separated ly about trice their own wilths; median groove long and strong; plisterma not distincty defined anteriorly; lygmotera polished througlout, coarsely, very lensely punctate, deeply impessol near the inner obtuse angle; inner marginal head distinet; inmer prsterior edge foming the maryin of the crural excavation abrupt, acute and ariniform. Aluhmen polisherl throughout, coarsely, very densely and deeply punctate, the punctures polygonally crowded ; tiftlo semuent conves, not impressed, nore densely pubescent in the niddle; pulescence thromgliont rather long, tine, and palesilvery-cinerens. Length $1.8 m$ m.

\section{Pennsylrania-Cab. LeConte. Texas.}

A well-marked species of wide distribution, varying considerably in size, but not olherwise to any noticeable extent.

L. nebudosies Lee.-Bu]l. U. S. Geol. Surv., V, 1. 515.-AOblongroval, stromgly roumded behind; sides mearly straight in the mildle: hlack, fulished throughout; pubeseence rather long, subremubent, rery rolust, sonewhat dense, confuserly mottled cinereons and fulvous. Iloded extremely coarsely and densely cribrate, the punctures rerg deep and polyonally crowded; supra-orbital ridges entirely olsolete. Prothorec nuch more than twice as wirle as long; sides distinctly although fechly arcuate; apex" nearly threefourths as wille as the base, the latter simuate on each sicle of the median lobe which is molerate; merlian groove very short, feeble; surtice extrenely densely, coarsely eribrate, the punetures pelygomally croivded, and only twothirls as wide as those of the elytra. Scutellum moderate, very shightly longer than wile, densely, marsely aribute, slightly convex ; sides and luase arenate. Elyto but very slightly wider than the prothorax, extremely densely eribrate, the punctures very coarse am deep, polygonally crowded, the lines of separation being lut one-fourth or one-fifth as wide as the punctures. l'rostemum coarsely but much more sparsely punctate, the madian growe very wibe and deeply excavated, extending almost to the apreal marem ; episterna not at all defined toward apex intemally. polished, inpumetate; hyponera extremely deeply impressed or excavated near the immer ohtuse angle. polisherl, rery coarsely, deeply and densely punctate; imler marginal bead very strong 
throughout; onter acute edge very feenly and gralually reflexed near the apex. dhelomen coarsely, very densely cribrate, the punetures polygonally crowimi ; pulescence rery fine, not conspicunds, that of the pubescent area of the last semment very short and fine, the same segment convex, not impresul. Length $1.7 \mathrm{~mm}$.

California (Aan Bernardino), LeConte; Texas (Austin) Anct.

The exceedingly coarsely and densely cribrate upper surface, and coarse mottled pubescence will at once distinguish this very interesting species.

L. olivaceus Lec.-Proc. Acad. Nat. Sci. Phila., VII, p. 116.-Oval, convex, in form and color nearly as in pmetutus; pulescence confusedly mottled cinerons and fulvous, rather sparser than in pumctutus; integuments polisherd. Hend rather coarsely, very deeply aml evenly punctate, the punctures dense lut distinctly soprarated. Prothorex rather more than twice as wide as long, the basal lobe narrow but well dereloped, truncate; sides feebly, erenly arcuate; merlian impressed groore distinct but not extending much in alvance of the centre; punctures equal in size to those of the elytra and eqnally sparse. Elytic nearly finr times as long as the jrothorax; sifles distinctly, broally arenate, towarl hase coarctate with those of the prothorax; ales rather acute: surface very evenly, rather sparsely punctate, the punctures round, deep and perferate, separated by one-half more than their own hiameters. Prosternum shining, herply groowel, strongly punctate, the punetures separated by their own wilths; femora rery coarsely, deeply pronctate, the metasternum moch more sparsely so. Alrdimen coarsely am very densely punctate toward the sides, much more finely so-the punctures separater by more than three times the distance-toward the midule and base. Length $2.1 \mathrm{~mm}$.

Michigan (Detroit). Mr. Schwarz.

The form described by LeConte as olivaceus has given rise to more or less divelgence of opinion. Henshaw in his list of the speries described by J. L. LeConte (1. 230), states that it is a ralid species. Tr. LeConte in his most recently published table of the genus (Bull. U. S. Geol. Sulv., Y, 1879, p. 515) unites it in synonymy with punctatus, and Heushaw in his check-list of North Anerican Coleoptera, appears to coincide with this opinion. I have perionally examined the specimen in the cabinet of LeConte which bears the type label, and find that it is absolutely identical with the type of punctatus, the punctuation being fully as dense as in that species. Schwalz has taken in abmundace at Iletroit, Nich., a slecies-lescribed above-which is allied to, but certainly distinct from, punctatus, having the elytral punctuation decidedly sparser but not quite as coarse; it is the opinion of Mr. Schwarz that this is the true olivaceus. 
I leave this subject, therefore, with the opinion that the specimen labeled olivarens in the cabinet of LeConte, is not the original type, and further that the specimens from Detroit may fairly be assumed to represent that species; the latter seems, at least. a better course to pursue than to give this undoubtedly ralid species a new name, hased upon an uncertainty of identification.

L. perforatus n. sp.-Fomn ohong-oval, strongly rounder behimr, rather less than twice as long as wide; siles nearly straight in the nindle; black: pulnescence very coarse, somewhat dense, feebly mottled cinereons and fulrous; integunents polished throughout. Head very marsely, deeply anl densely punctate, the punctures on the that vertical front tending to coalesce in a snbtransverse, slightly posterior direction from the median line. Prothmex more than twice as wille as long; silkes fechly, evenly but very distinctly arcuate; aprex more than tro-thirls as wirle as the base, the basal lobe moxlerate in wilth, prominent; median groove short, broally, feebly inpressed am not very distinct: surfice rather finely, sparsely punctate, the punctures minch less than me-half as wide as those of the elytra, and separated by twice their own widths, coarser and denser toward the sides. Scutellum molerate, shightly convex, just visilly longer than wide; silles very strougly areuate; base feehly so; basal angles rounted; surface ratleer sprarsely and finely punctate. Elytim hut shightly more than three times as long as the prothorax and scarcely perceptitily wider, rery coarsely, depely and densely pmotate, the punctures separated by one-half their own wilths. Prosternum polished, extremely finely and sparsely punctate throughont; melian groove narrowly but deeply impressed, continuous almost thronglinat the entire length; epistema approaching the apex within two-thinds their own length, abruptly linitert within exceyt near the anterior angle, impunctate; hypomera very strongly impressed near the inner augle, polisher, rather coarsely punctate, the punc. tures separated by abont twice their own diameters; imner bear strongly developert. Aldumen in the mishle not very coarsely punctate, the punctures separated by twice their own widths, coarser and slightly closer mear the sirles, porygonally crowled on the last segment which is not impressed and with the linhecences dense in the mirlle. Length $1.7 \mathrm{~mm}$.

California (Santa Clara Co.).

This species is distinguished by its remarkably sparse and fine punctuation of the prothorax, alove and beneath, for this section of the genus, and contrasting remarkably with the very coarse dense punctuation of the elytra. The abdomen is much more sparsely punctate than in any of the other species of this subgenus.

\section{***}

L. temuicornis n. sp.-Oroidal, pointed behind, abont three-fourths longer than wide, willest near the millle, back, moderately shining; pubes- 
cence molerate in length am lensity, uniformly dark fulsons thronghome

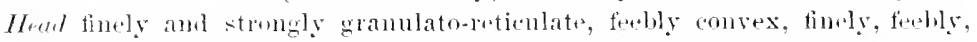
sonewhat sparsely and not distinctly functate; "pistona more enarsely and densely so: ejpistomal suture fine; lateral antemnal emarginations dente exposing the entire hasal joint of the antemute which is large. Prothorer mudn more than twice as wille as long; siles wery feebly arcuate; apex two-thims as wille as the hase, the latter sinnate at each sitle of the lasal lole which is

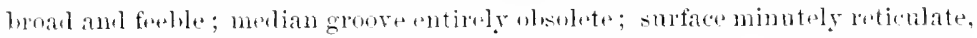
very strongly so near the sides, exossirely oheoletely so in the midille; functures very fine and sparse. Scutellum large, edpulatero-triangular ; sides and

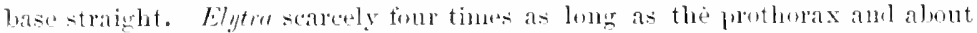
ons-thim willer; siles strongly arenate aml conctate with these of the pro-

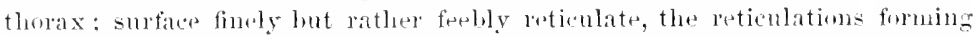
folyenal rings alunt the punctures, the latter very minute, eas he in the centre of a small reticulation, and entirely filled by the hair arising therefom, wather sparsely and arenly distributed. Prostemmen transfersely convex, without trace of inpressed gronce, very minutely, sparsely punctate, reticulate laterally ; episternum small, not approaching the apex by its own length, very abroptly and charly limited: hypomera tlat, reticulate, not impresseml, very minutely sparsely junctate. without trace of imer marginal lwal. Alutumen finely and stmegly leticulate throughout, tinely, sparsely functate, the last segment mere lemsely so; pulescence wather long, coarse and sparse, denser in the midule of the last segment which is not at all impressed, the alex with a hroad shallow emargination. Length $1.8 \mathrm{~mm}$.

California (Hoopa Valley, IIumbolett Co.).

For the present this species may be considered the trpe of a subgenus of Limniehus, but it is almost uncunestionably of ligher value, the unimpresised prosternum, long antemne, and large equilateral seutellum distinguishing it at once from any of the other's. If it is considered generically distinct, howerer, the lutrochims group must also be separated on other, but equally decisive characters.

\section{$* * * * *$}

L. Haviculatus n. sp.--Amost erenly oral, about three-fourths longer than wile, acutely rounder but not jwinted behind, convex, lufu-castantons ahove, slightly paler rufo-ferruginons heneath, feebly shining. Ihed rather convex, excessively ininntely, moderately densely junctate. Prothorer small, fully two and one-half times as wille as leng: sides straight; alex mearly three-fourths as whle as the hase; basal lobe rather short and feeble; disk extremely minntely and moderately demsely punctate, the median groove conpletely obsolete. Sentellum small, flat, efuilatero-triangular. Elytru fully four times as long as the prothorax and one-third wider ; sides strongly, erenly areuate and coarctate with these of the prothorax; surface polished, not reticulate, the larger punctures-hearing the longer hairs-small, perforate, separated by from four to five times their own diameters, the mimute 
recumlent pubesence easily removable, am leaving merely a minute superficial sear. Prosternum not listinetly punctate, minutely, feelly seabrons and alutaceous, the merlian groove deep lut narow; episterna transverse, sluert, the inner marginal line listinet, broally arcuate; metastermm with the fierforate punctures abont equal in size to those of the elytra, and separater hy ahout three times their own wilths. Abtomen dull, exeessively minutely, densely pubescent, the perforate punctures completely wanting. Legs molerate; intermetiate tarsi shont, about one-halt as long as the tibia, but with the second joint rather longer than wide. Length $1.5 \mathrm{~mm}$.

\section{Texas. U. S. National Musemm.}

In its entirely impunctate aldomen this species differs from any other of the suhgenus; it somewhat resembles ovatus, but differs in its more elongate form and in its coarser elytral punctures, these leing alout twice as large as in that species. 'The longer hairs of the elytra in ovatus are longer than in naviculatus, and the short appresied ones much sparser. In ovatus there is no trace of maculation, whereas in the present species the pubescence is paler at three indefinite lateral spots on each elytron, giving, under extremely low power, the appearance of three imperfect transverse fasciz; in the former the intermediate tarsi are nearly two-thirds as long as the tilitie.

L. Iutrochinus Lec.-Bull. L. S. Geol. Surv., V. p. 515.-Oroidal, grandually pointed behind, nearly trice as long as with, witlest near the nuiddle, piceons-lowern, very densely pubeseent; integunents shining. Iferd finely ant very sparsely punctate. Prothorax more than twice as wile as long; sicles straight; alrex two-thirds as wide as the hase; median lohe small, distinct; metian groove olsolete; surface shining, very feehly reticulate near the sides, wht very coarsely, very sparsely punctate, with the interspaces much more minutely, densely punctate. Scutellum small, slightly longer than wide, ferby convex, densely pubescent; sicles and base festly arcuate. Elytro ahout three and one-half times as loner as the prothorax: idfes distinctly areuate and nearly coratate with those of the prothorax, the huneri almont impunctate and slightly, longitulinally tumid; surface rather coarsely, sparsely punctate; punctures perforate and separated ly from three to four times their own diameters: interspaces polished, the minute recmmbent liairs not arising from definite punctures. Prosternom shining, minntely and not very demsely punctate, much more densely punctate and al utaceons anteriorly: median groove fine, extending nuarly to the apex; episterna short, lowally triangular, clearly linited within thronghout, the inner margin arenate; liyponera tlat, not impressecl, minutely, densely reticulate, dull, minutely,

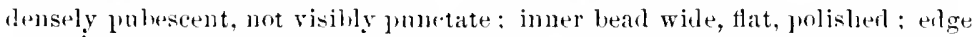
of the erual eavity acute and carinifom. Aldemen very dull, rather finely, very sparsely functate, the interspates excessively minutely, densely punc- 
tate and pulescent ; last segment not impressed, having longer and more conspicuous pubescence. Length $1.5 \mathrm{~mm}$.

Texas. Cab. LeConte, Belfrage and Schwarz.

The dual nature of the pubescence has been referred to as a group character, and has not been mentioned in the description. The longitudinal groove in the elytral epipleura near the apex is very fine, and less developed than in group I.

L. seriatus $n . s_{1}$, - Oral, convex, about three-fourths longer than wile, rather gralually pointed behind, castaneous above, rufo-ferruginous leneath, feebly shining. Hrad convex, extremely minutely and rather densely functate. Prothorux a little more than twice as wide as long; sides nearly straight; apex fully three-fourths as wide as the base; hasal lobe small, rather fireble; disk excessirely minutely, feebly, rather densely punctate, the median groove completely ohsolete. Scutellum very small, slightly longer than wide, acutely pointed; sides straight; surtace minutely, feehly reticulate. Elytrefour times as long as the prothorax and nearly two-fifths wider; sides feebly areuate anteriorly and not coarctate with those of the prothorax, the width at the hmmeri being distinctly greater than the base of the latter; surface polished, not reticulate, very minutely punctate, the punctures about as large is those of wretus, and separates by from four to five times their own diameters, somewhat nnevenly distributed. Prosternum rather dull lut not punctate, the median groove fine but deep and distinct; metasternum strongly and sparsely punctate, the punctures decidedly larger than those of the elytra, and separated by alout three times their own widths. Abdomen finely, sparsely punctate, the punctures perforate, searcely as large as those of the metasternum, lont rather larger than those of the elytra, separated by from four to fire times their own wiclths; fifth segment entirely impunctate, except a single line of punctures along the hase. Intermediate tarsi nearly two-thirds as long as the tibie, the joints two to four very short, transverse and oblique, almost exactly equal. Length $1.2 \mathrm{~mm}$.

Florida. Mr. Schwarz.

The large hairs of the elytra are but slightly longer than the fine short subappressed ones, and are entirely inconspicuous; there are, however, on each elytron four series of long erect white sete which are very widely spaced; these contrast strongly with the general vestiture, when viewed under light coming horizontally along the axis of the body and from the front. I have not noticed these seta in any other species, although they probably exist, and are sinply nore prominent in the present case because of the extraordinary shortness of the general pubescence. This last character will easily distinguish seriatus from ovatus. The elytral pubescence is fulvous in color and entirely devoid of maculation. 
L. Ova tus Lee.-Proe. Acar. Nat. Sci. Plila., VIl, p. 117.-Evenly wate, rather acutely pointed behind; sides strongly arcuate; picesus-black alove, slightly pales, piceous, beneath; legs and antenure dark rufo-testactoms; integuments polished throughout above; pulbescence very conspicusus, pale brown. Houl convex, vely finely, sparsely punctate, phlished; epistomal suture deep and strong; epistoma scabrous amd dull. Prothoror two and onelalt times as wide as long; siles straiglit; apex rather more than two-thirds as wirle as the base; hasal lobe small and feeble; surface polished, slightly scabrous and reticulate at the sides near the apieal angles, finely, spar-ely fonctate, the intervals excessively minutely and feehly punctate; median groove obsolete. Scutellum very small, exuilatero-triangular, that; sides and base straight, the former arcuate near the hase. Elytu nearly four times as long as the prothorax and one fourth wider; sicles evenly rather strongly arcuate and coaretate with those of the prothorax; humeri not distiuctly tumid: surface polished, very finely, sparsely punctate; punctures perforate, distant by from four to six times their own diameters; interspaces as in lutrochims. Prostornum shining lehind, dull near the apex; median gronse fine, distinct, attaining neither the anterior nor fosterior margin; "pisterna very short and broad, polished, clearly limited, the imner margin stromgly arcuate; byponera flat, not impressed, dull, not visilly punctate, inner polished bear that, short, the margin of the crural excavation tinely acute and cariniform, and nuch longer than the leaded side. Aludomen stromgly opanne, mintely, sparsely punctate; last segment with scarcely denser pubesconce. Length $1.3 \mathrm{~mm}$.

\section{Southern States. Cab. LeConte.}

The systematic relationship of this small species may rearlily he seen from the tahle; it is more convex and less oblong than serialus, with the sides more strongly areuate, and the prothorax relatirely narrower and more strongly narrowed from base to apex.

L. punctiventris 11 . sp.--Evenly oval, two-thirls longer than wide, convex, black above, dark rufons beneath, rather strongly shining. Heud convex, extremely minutely, somewhat densely punctate. Prothorax small, more than twice as wide as long: sides nearly straight; apex three-fourths as wide as the liase, the lrasal lole small, not very frominent; surface tery ninutely, feely punctate; pubscence rather sparse; median groove obsolete; along the apical margin there is a series of minute granulations, in advance of which the marginal surface is thin, senicoriacens and polished. Scutellum small, equilatero-triangular; sirles straight; surface polished. Elytre fully four times as long as the prothorax; sides distinctly arcuate and almost coaretate with those of the prothorax, the hmmeri being but just visibly proninent: disk very minutely punctate, the punctures unevenly distributed, and separated by from three to six times their own widths, but generally alout four, beconing much coarser but not denser towark the siles; minute puluscence rather long, coarse and not extremely deuse, the longer hairs sparse, although decidedly longer. Prosternum feebly shining, more polished prote- 
riorly : median groove very fine but distinct and almost entire; metasternum shining, rery finely, sparsely punctate, the punctures perforate, not larger than those of the silles of the elytra, but rather coarser and denser laterally, separated by from three to fire times their own widths. Alwmen more coarsely and rery deeply punctate, the punctures rery demse laterally, where they are selarated by about their ow wilths, rather finer and distinetly sparser towarel the midhe, the fifth segment almost completely impunctate except near the hase. Length $1.3 \mathrm{~mm}$.

Florida. Mr. Áchwarz.

The rather shining surface, lack color and coarser, very dense ahdominal punctuation will render the identification of this species very casy. The series of longer coarser seta on the elytra, mentioner under seriatus, are represented here hy the marginal series only, the others being not distinctly traceable.

\section{PHXSEMUS Lec.}

Regarding the relationship of the three genera Bothriophorus, I'hysenus and Ditaphros, the following observations may prove intere-ting.

In the remarks appended to the original description of Itaphrus (13ull. Cal. Acad. Sci., II, Pp. 250-253), the reasons were given for the separation of the genus fiom Physemus; they were based solely Hpon the original description of the latter as griven by Dr. LeConte. After the publication of Ditaphrus the suspicion of its identity with Physenus continued to grow mpon me, until I determined to discover the truth if possible hy actual observation. I accordingly made a journey at consirlerable expense from San Francisco to Yuma, inciclentally for the purpose of collecting Coleoptera, but copecially to rediscorer the speeies Physemus mimutus. Knowing the haunts of Litaphras scymmoides in Texas, I did not have to search long before finding LeConte's species in numbers, moring slowly over the surface of moist adobe mud, under débris of fallen leares. An examination at once revealed the faet-as I had anticipated-that the two genera are identical in every point of structure, and that the specics also are the same, althougb presenting very slight differences in size and restiture.

Wishing to carry the investigation a step further I have procured from M. Desbrochers des Loges, a specinen of the European Bothriophorus Muls, and find on examination that, while resembling Plyysemus rery closely, it differ's decidedly in antennal structure. 
If the student will have before him the figure of the antenna of Physemus (1. c. plate), he can more readily appreciate the diflerences as indicated in the following description :-

First six joints somewhat similar to the same in Physemus. Seventl joint slenlel, cylindrical, nearly twice as long as wille; eighth just visibly willer than the serenth and one-half as long, triangular, the vertex of the angle directed anteriorly, the posterior sicle straight; ninth triangnlar, transverse, the angle on the anterior side, the posterior side nearly straight, scarcely longer and one-half wider than the eighth; tenth almost evenly obtrapezoidal, scarcely longer than the ninth but distinctly wider, two-thirds wider than long, closely joined to the eleventh throngliont the width; eleventh ovoilal, pointer, slightly wider than the tenth, two-thirds longer than wilk, slightly longer than the two preceding joints combined and more densely pubescent.

It will be seen, therefore, that the two genera are quite distinct in antennal structure, the one having a two-jointed, and the other a three-jointed club.

The species_b. atomus Muls._is somewhat smaller and more finely and very much more feebly punctate than Physemus minutus Lee.

\section{PARNID E.}

\section{THROSCINUS Lec.}

Elongate-elliptical, convex, punctate, pubescent. Head deflexer ; eyes and labrum visible in repose; epistomal suture fine, straight; epistoma transversely trumeate at apex; labrum large, transverse, convex, broally, foebly sinnate at ajex ; antenne inserted at the sides of the front, base not concealed, 11-jointerl ; basal joint twice as long as the second and much more robust ; last six joints broader, forming a very elongate, slender, perfoliate club; last joint of the maxillary palpi elongate, slenter, acuminate, with a minute apical process. Prosternum large, truncate anteriorly; process very wide, with two fine lateral carine which extend diverging anteriorly for more than one-half the distance from the coxa to the anterior margin, not grooved in the middle, the apex broally arcuate, received in a very broad shallow emargination of the mesostermum; the latter very short, widely separating the coxit; metasternum large; episterna narrow ; posterior coxie widely separated, flat abwe, sulcate leeneath, triangular, prominent internally, only extending to the metasternal epinera. Anterior anl intermediate legs rather short, simple; tarsi all morterate in length, free, slencler; four basal joints short, subeunal; fifth as long as the three preceding together. Epipleuræ very narrow posteriorly, broader, flat and simmons toward base, not at all exeavated or inn ressed for the intermediate femora, the basal margin closely fitted throughout its wilth to the hypomera; the latter wide, llat, separated from the prosterual side-

Axrals N. Y. Acad. Scr., V, Feb. 1890.-11 
pieces, the coxæ and trochantin by a fine, nearly straight snture which, anteriorly, becomes a deep groove for the reception of the antenna, and which is the posterior prolongation of deep grooves beneath the eyes. Prothorax fitted to the elytra throughout the width of the latter, with the basal angles acate and slightly produced posteriorly.

This genus was founded by LeConte upon the Californian representative $T$. Cootchii, which is more slender than the present, more finely and much more densely punctate and pubescent, the hairs being somewhat confusedly matted as in Theterocerus. The above diagnosis was drawn from the Texan speeies which seems to be identical in generic characters.

T. politus n. sp.--Black ahove; legs and under surface rufo-piceous; aldomen paler; antemne black; integunents snlalutaceous beneath, very highly polished alowe, rather coarsely and sparsely pubescent; hairs short, erect, denser and finer on the head. Ihad molerate in size, deeply seated in the prothorax; front vertical in refose, feebly, rvenly convex, very finely and feebly punctate; eyes large, rather prominent, "ntirely exposed, on the sides just before the prothorax; antemuse slightly longer than the width of the learl, slemer; joints three to five very slender, the third almost as long as the fon rth and fitth together. Prothorax widest at the base, where it is two-thircls wider than at apex; sides evenly, feebly arcuate; hase transverse, rather abruptly and strongly arcuate in the middle third; posterior angles very acute, slightly prorluced; ales broally, feebly arcuate; disk nearly twice as wille as long, hroally, rely evenly conves, finely, sparsely punctate, the interspaces extremely minutely and feelly punctate. Scntellum very distinct, flat, polished, inpunctate, ogival, pointed, as long as wide. Elytm at hase equal in width to the prothorax; sides parallel, feebly arcuate for two-thinds the length from the base; together gradnally rounded behind, acute at the apex ; disk evenly convex, nearly three times as long as the prothorax, very coarsely and strongly punctate; punctnres impressed, evenly distriluted, obsolete at base; interspraces more than twice as wide as the punctures, not at all punctate. Ender surface very finely, densely pubescent, the hairs short and closely recumbent; abdemen extremely minutely gramulose, not punctate; segments decreasing very slightly in length to the fourth, fifth shightly longer; surface conrex; sutures feeble, straight. Length $1.7-2.0 \mathrm{~mm}$.

Texas (Galveston).

A rery good series of this interesting species was obtained from the vegetable detritus, covering the interior line of sand dunes, along the ocean beach. 


\section{I.UCANIDE.}

\section{PLATYCERUS Geotf.}

A sexual character, which seems to have escaped obserration, exists in perluaps its greatest development in quercus. It will be seen that in this speeies, the posterior tarsi of the female are muth shorter than in the male. In oregonensis the same condition holds, but to a less-marked degree, and in Ayassii the character rompletely disappears, the tarsi in both male and female being rery long and slender, with the fourth joint twice as long as wide. The type of californicus is a female, and, as the posterior tarsi are extremely short, relatirely more abbreviated even than in the fomale of prercers, with the fourth joint fully as wide as long, it is probalk that the male, also, has a shorter tarsus than Agassii, and that the species is to be associated with quercus and oregonensis, rather than with Ayassii.

Through the kindness of Mr. J. J. Rivers of Berkeley, California. who has made the study of this genus somewhat of a specialty, I have been permitted to examine a larger series than has been hitherto available to me, and find that there are sereral species similar to Agassii in having the mandibles small and inconspicuous in the males, and the hind tarsi nearly as long as the tibiue. The series alluded to affords sufficient material for a tolerably complete study, and consists of twelve specimens of Ayassii, three of pacificus, and two of parvicollis. These three species nay he defined as follows, the characters given referring to the male only:-

Sides of the prothorax-viewed vertically-distinctly subangulate.

Pronotum finely, densely punctate; antennal club much longer than the funcle, the last joint strongly asymmetric, the longest dimension beinu in a direction oblique to the axis of the club, and very much exceeding the wilth ; sixth joint of tunicle strongly produced anteriorly ; fitth joint of hind tarsi as long as the first and second combined; tytra eyual in width to the prothorax.

1 I have recently had oceasion to inspect the original female type of Agrssii in the museum at Cambridge, Mass., and find that the specimens lieretofore regarded by Mr. Fuchs and myself as representing that species, were correctly identified. The type, apart from its sliglitly paler color due to immaturity, does not differ in the slightest degree from the average female, and the punetuation of the pronotum is equally dense. 
Pronotmm much more coarsely and sparsely punctate; antennal club equal in length to the funicle, the last joint much less, although distinctly, asymuetric, slightly longer than wide; sixth joint of funicle just visibly more prominent anteriorly ; fifth joint of hind tarsi distinctly longer than the first tro combined; elytra at apical two-fiftls fully one-fourth willer than the prothorax; color pale, brown

parvicoll is

Silles of prothorax-viewed vertically-broadly, evenly arcuate, subangulate when viewed laterally, the snrface much more convex and declivous at the sides; pronotum tinely and rely sparsely punctate; autemnal club slightly but distinctly longer than the funicle, the last joint willer than long; sixth joint of funicle not at all prominent anteriorly; elytra equal in wilth to the prothorax; surface lighlily polished; color deep black...

pacificus

P. parricollis n. sp.-Form slender, rather depressed ; siles parallel : dark reddish-brown, somewhat loronzed; head and pronotum darker; legs throughout dark hrown; integuments polished. Head rather small, coarsely. deeply and rather densely punctate; front with several long coarse fulvous sete; mandihles small; antennal club abont equal in lengtlı to the funicle; last joint very slightly oblique, slightly longer than wide. Prothorax small, willest rery near the midlle where it is nearly twice as wide as long, and where the siles are distinctly angulate from ahove, the angle narrowly rounded; ales broads, rery feebly emarginate, slightly narrower than the luase; the latter transversely truncate; angles slightly prominent, acute, not at all rnumlerl; silms nearly straight anteriorly and posteriorly, rather strongly (onvergent in both senses, feebly sinuate near the base; disk broadly, feebly conrex, rather broally but not strongly reflexed at the sides, coarsely and strongly punctate, the punctures rather sparse in the middle, with a narrow, incomplete, inpunctate nedian line, dense toward the sides, except in the reflexed frortion, where they are very sparse and coarser. Scutellum much wiler than long, parabolic, very sparsely, coarsely pructate at hase. Elytro at base fully as wide as the prothorax; sides parallel, distinctly arcuate belind, nearly straight and feebly divergent in the basal fourth; together evenly am rather strongly rounled behind; disk transversely and moderately convex. four-fitth longer than wide, three and one-third times as long as the lruthorax, willest at two-fifths the length from the apex where it is one-tourth willer than the latter ; strice nearly equidistant, feebly impressed, rather finely, deeply punctate, the punctures closely approximate; intervals feebly convex, -larsely creased. finely, unevenly and sparsely punctate. Leys slender: posterior tarsi just visibly shorter than the tibice. Length $10.3 \mathrm{~mm}$.; width $4.0 \mathrm{~mm}$.

\section{California.}

Readily distinguished from Agassii and pacificus by the pale color, small prothorax which is here much narrower than the elytra, and hy the great relative length of the latter. The type is a male; the antewual club being relatively very much shorter than in either of the species mentioned. In Agassii the funicle is three-fifths as 
long as the club, in pacificus three-fourths, and in parvirollis about equal in length, the comparisons being made from males. In the female of Ayassii the club is small and very distinctly shorter than the funicle.

P. pacificus n. sp.-Oblong, rather convex, polished, black; sides parallel and nearly straight. Hend morlerate in size, sparsely, coarsely punctate; antemal club distinctly longer than the funicle, last joint almost symmetrical, distinctly wider than lons. Prothorax widest at one-third the length from the base, where it is two and one-half times as wirle as the hearl, and two-thirds wider than long; sides-viewed vertically-broally rounder, sinuate near the basal angles which are acute, not romderl, and slightly prominent; apex slightly narrower than the hase, broally and feebly emarginate, the latter transversely truncate; disk broadly convex, rather broadly and strongly retlexed at the siles, very sparsely, finely punctate in the midhle with an impunctate median line; punctures much denser laterally; in the reflexed portion along the margin they are again sparser hut much coarser. Scutellum ogival, slightly wider than long, punctate at base, impunctate in the apical half. Elytire at base about as wide as the prothorax; sirles parallel. distinctly arcuate posteriorly, straight in the basal third or fourth; together broanly romded lehind; disk transversely, rather strongly convex, two and three-fourths times as long as the prothorax; strire teeble, rather closely functate, equidistant; intervals very feebly eonvex, creased, more finely and very sparsely punctate. Legs black; tarsi very slightly paler toward apex, the posterior nearly as long as the tibia. Length $10.0 \mathrm{~mm}$, ; width $4.2 \mathrm{~mm}$.

California.

This species is casily distinguished from Agassii by its rery sparse punctuation and form of the prothorax, the sides of the latter heing much more broadly rounded, when viewed vertically, than in Agassii, although when riewed obliquely they are subangulate.

\section{SCARAB.EID.E.}

АСОМА n. gen. (Melolonthinx).

Clypeus rather prolonged, concave; apex witl a small median notch and feebly bidentate, strongly inflexed for a great distance beneath, the lalrum entirely connate and obsolete, not visilsle except as a minute reflexion of the infraclypeal surface. Mentum nimute, very narrow, elongate, nearly flat. Naxille large, the palpi rather large; basal joint small; second and thirl sulequal, longer than wide; fourth as long as the preseding together, wider, elongate-oval, with a broal shallow groove on the onter face thronglont the length, the apex with a minute oval impressed area. Lalial palpi very minute. Eyes large; inferior portion much larger than the upper, separated 
beneath by much less than their own width. Antennæ nine-jointed; hasal joint as long as the next three together, slender at hase, strongly inflated towarl apex, the apical margin fringed with a single row of long erect setre; second wirler than lons, narrower than the first, strongly narrowed at base; thiril to fifth subequal in length, longer than wide, subcylindrical and subanchylosed; sixth very short, strongly transverse, slightly wider; seventh to ninth forming a very large club, twice as long as the stem-measured in a direction perpendicular thereto-strongly arcuate toward apex, and, in shape and relationship with the stem, exactly as in Polyphylla. Vertex with a fine longiturinal ridge orer each eye; clypeal suture obsolete except near the sides where it is fine and transverse. Anterior nargin of the pronotnm with a broad flat had thronghont; posterior margin with a very much fimer one, which lecomes abruptly very fine in the midkle and also laterally. Scutcllun rather laro, ogival. Elytra projecting well behind am pratially concealing the pyrilium. Anterior coxa large, transverse, strongly conical and prominent internally; prostrumun very short before them, the anterior margin broadly lisinnate between the strongly alvanced and acute anterior angles of the fronotun; hypomera rather wile, nearly flat and ahost horizontal; fenora large. lnoad, flattened, posterior very large; anterior tibire with a small acute internal spur near the apex, two external obtuse teeth, and a prolonged apical process which is slightly dilated toward apex; middle and posterior tibir robust, festnoner in the middle with an oblique girdle of spinules, obliquely truncate and dilated at apex, with a fringe of short robust spinules, and two long terminal spurs; tarsi very long and slender, twice as long as the tilia ; joints very long, slender and cylindrical; lrasal joint longest; claws very slemler, long, finely acuminate, very feebly arenate, equal and very minutely carinate internally at base. Hetasterum very obliquely trumeate at the sides lwhind, in the midale longer than the abdomen; episterna short and broad. Almbmen extremely short in the middle, broad, consisting of five segments; sntures distinct throughout the wilth ; first segment almost completely covered by the very large posterior coxie. l'ygidium moderate, ahout as long as wide, trebly convex, rounded at apex, very feebly and inwardly oblique.

The very long slender tarsi and nine-jointed antenna seem to point at first to a relationship with Maerodactylus, but the very large mentum, feebly inflexed clypeus and abdominal strueture of the latter prohibit any such assoeiation. From the Sericini it differs in its very minute elongate mentum, this organ in that group being large and transverse. From the Dichelonychini it dilfers in its minute mentum and obsolete labrum, and from all these in the form of the labial palpi. The latter are extremely minute, scarcely risible, and closely aplroximate, the two basal joints rery suall, subglobular, the third longer than the first two together, elongate-oval.

In the genus Porlolasia the clypeus is formed nearly as in Acoma, but is slightly more dereloped above, and inflexed for a mucb shorter 
distance beneath. The labial palpi are large and very evident; the antennæ are nine-jointerl, with a small robust three-jointed club, and with the seeond joint large and globular; the anterior tibie are devoid of internal spine, and the long apieal process is acute and strongly excurvate. The claws are long and slenter, with a small longitudinal earina interually at base, but not properly toothed. The first four abdominal segments are connate, the sutures axcessirely feeble in the middle, but not entirely obliterated, the fourth suture wide and nembranous.

I think, therefore, that this interesting genus may be placed for the present near Podolasia, but with the assumption that it constitutes a connecting bond with some other group in its almost perfectly free abdominal segments, extremely minute lalsial palpi, and greatly developed anteunal club of the male.

In Chnaunanthus the ventral sutures are absolntely obliterated in the middle, and this genus is therefore a more highly specialized representative of the group Oncerini, than either Podolasia or Acoma.

A. brummea 1 . sp.-Form oblong, the sides nearly parallel, moderately convex, dark reddish-brown throughout; head and prothorax almost glal.rons, but rather densely fimbriate with tong erect hairs at the sides; elytra sparsely clothed with rather long erect hairs, which are longer and more comsicums at the siles; moler surface loristling with long slender sparsely placed hairs, especially conspicnous on the fimbriate femora. Head coarsely, very densely and deeply rugoso-punctate, the elypeus, which is nearly as long as the remainder of the head, coarsely, deeply and sparsely punctate. Prothorac four-fifths wider than long; siles strongly rounded just belind the midrle, thence convergent and feelly sinuate to the acute apical angles, hroally rounder to the base, the hasal angles being broadly roumled and obsolete; base hroally, very feebly arcuate, alruptly distinctly and more strongly so opposite the scutellum; apex broally emarginate, bottom of emargination hroully bisinuate; disk moderately convex, polisher, feebly impressed along the median line except near hase and apex, finely, sparsely punctate; punetures entirely wanting in a broad median line, and also along the basal margin. Scntellum ahost impunctate. Elytra widest in the midhle, slightly longer than wide, very slightly wider than the prothorax; sides parallel, feehly arcuate, together broally, obtusely rounded behind ; humeri slightly prominent; disk feebly convex, strongly so at the sides, finely, feebly ant nuevenly striate; stria more approximate and very much confused at the sides, where the surface is distinctly rugulose; strie very finely and approxinately punctate; intervals each with a very meven single line of larger, more distant punctures. Length $5.0-5.5 \mathrm{~mm}$. 
Texas (El Paso). Mr. G. Wr. Dunn.

This very anomalous little beetle apparently lives in flowers or on plants; the three specimens before me are males; I have not seen the female.

POLYPHYLLA Harris.

The American species of this genus appear to agree very well with the European, and differ principally in their shorter, more robust legs. The following species belongs near decemlineata, and ma $y$ le at once interpolated in the table given by Dr. Horn (Trans. An. Ent. Soc, IX, p. 73).

P. speciosa n. sp.-Elongate-oval, convex; prothorax trivittate; lateral vittie interrupted.

Femele.-Head much wider than long; dypens two and one-half times as wide as long; sides parallel, feebly arenats; apex broanly and very feebly bisinuate, the lateral angles acute, nore prominent and more strongly reflexed ; front coarsely and very densely punctate, rather sparsely clothed with short elect hairs, and squamose with large pointed scales toward the eyes and alnng the margins of the clypens; antemne rather robust; bast joint pryiform, lwhist, as long as the next two tugetler ; second and third elongate, the latter much the longer, fourth obonical, slightly. produced inwarlly at apex, fechly transverse; club feebly arcuate, six-jointed, first narrower and more aenminate than the others, pointed, and but little more than one-half as long, renaining joints equal in length and nearly as long as the entire stem including the lasal joint. Prothorex widest just behind the middle, narrowed rather rapidly thence to the apex, the latter about tro-thirds as wide as the base, broally emarginate and feebly bisinuate; base broadly arenate, more strongly so in the middle; sides suliangulate, angle narrowly rounded, thence just risildy arcuate to the apical angles, and extremely feebly sinuate to the base, lroally and rely feebly suberenulate thronghout; basal angles obtuse, not at all ronnded; disk convex, with a rery small feeble impression near each lateral elge at the middle of the length; vitte white, very dense, the lateral interrupted anteriorly, remainder sparsely covered with large elongate pointed yellow scales, which are denser near the basal margin except in the middle; surface anteriorly with a very few short erect hairs; punctures large, shallow, roumd and variolate, rather densely but unevenly distributed, each enclosing a seale. Scutellum broadly parabulie, rittate. Elytra three-tiftlis longer than wide, in the middle one-thind wider than the prothorax; sides parallel and feelly areuate, subtruncate heluind; humeri slightly tumid; apical numbones large and feelile; each elytron with three broad dense white vitte, and a fourth very narrow and interrupted between the second and thirl from the suture; third ritta abruptly terminating near the apex, feebly and evenly arenate thronghout, first and second meting on the apical umbo, the first irregular toward base; suture narrowly vittate, the vitta continuing 
to the apex; intermediate surface finely, sparsely punctate, and covered sparsely with molerate pointer yollow scales. Pygidium slightly witer than long, triangnlar; sides equally arcuate; surface teelly convex, slightly impressed at the sides, sparsely clothed with elongate whitish scales which are lense along the base, and much sparser in a very narrow median line; surface aho very sparsely and finely pubescent. Aldomen with suall robust whitish scales, much denser along the apical margins of the segrnents, and also with rery sparse erect pubescence. Lengrth $36.0 \mathrm{~mm}$.

Colorado (exact locality unknown- + ) ; New Mexico- $\delta$.

This fine species is easily distinguishable by its antennal structure from any other in the genus. The last joint of the maxillary palpi is rery feebly lunate, and is pointed at apex. The anterior tibix are robust, the outer teeth strong, the one nearest the base very broad, obtuse, and feebly dereloped. ${ }^{1}$

1 I take the present opportmity to describe an interesting new species. received a short time since from Central America. The description refers to the female.

P. concurrens $1 \mathrm{~s}$ sp.-Form nearly as in decemlinenta, pate brownishrufous. Clypens truncate, broally arenate in the mildle; angles right, not rounded, lout also not prominent, its surface feely and very narrowly reftexed at the apical margin, having a few wirlely scattered, coarse, squanigerons punctures; front immediately belind the suture abruptly, coarsely, extremely lensely and deeply punctate, the punctures in mutnal contact, the occipt arain abruptly totally impunctate: antemme moderate, club as long as joints two to four combined; sixth joint rather less than one-half as long as the remainder, which are equal. Prothorax nearly as in decemlineta, lint very much more sparsely punctate, the median line very deeply inpressed, and the ritte narrow ; scales large and robust. Scntellum polished, with a narrow median vitta. Elytre with ten very narrow, densely squamnse vittie, the second from the lateral margin long, extemling to apical third, hit rery willely interrupted; intervals extremely sparsely squamose, the scales smaller and narrower than those of the vitte. Length $25.0 \mathrm{~mm}$; width $11.0 \mathrm{~mm}$.

Honturas. (One specimen.)

Althongh resembling deremlineata, this species is smaller, less robust, and differs greatly in the form of the prgitimn, which is slightly longer than wille, transversely convex, and extremely sparsely squamose, a narrow median line entirely glabrous. The antering tibice are tridentate, the hasal tooth rery broad and feebly developed. The front and vertex in this species, and also in speciose, are very much more densely and coarsely punctate than in dicrmlineata, where the punctures are separated ly their own wilths. All comparisons have been drawn from the fomale, which is the more constant sex. 
THYCE Lee.

The single species, which has been regarded as the type of this genus, has hitherto been represented by a single female, and the recent discovery of the male ly Mr. Dunn at El Paso, Texas, indicates the absence of generic difference between it and most of the Californian species separated as Plectrodes.' The structure of the antrior coxe is identical, and the teeth of the tarsal claws are quite plainly unequal, to fully as great a degree in fact in $T$. squamicollis, as in many of the recognized species of Plectrodes. Our species may be sejarated as follows, the characters referring to the males:Fourth joint of the maxillary palpi one-third as long as the antenual club. ${ }^{2}$

carpenteri

Fourth joint three-fifths as long as the antennal club; elytra nearly glabrous.

Fourth joint three fourths as long as the antennal club.

squamicollis

Elytra moderately densely pubescent; last palpal joint oral, with the groove almost evenly elliptical ${ }^{3}$.

palpalis

Elytra extremely densely chotbed with very minnte, recumbent, squamitorm hairs; last palpal joint robust, the groove widening toward base.

pulverea

Fonth joint just visibly shorter than the antemal club, the apex acute and deflexed.

fossiger

Fourth joint two-thirds longer than the antenual club

Harfordi

In Carpenteri and also in Plectrodes pubescens the excarated groove in the fourth palpi joint is narrow, shallow and feeble, and is much shorter than the joint; in the rentainder it is narrow, rery deep, and extends throughout the lengtb.

The females are much less abundant than the males, and differ considerably. The fourth palpal joint is small and more uniform in size with reference to the antennal chb, and, although impressed externally, the groove is shallow and only partial, even in the

1 The genns Plectroles is representer only by the original $P$. pubcrens of Horn. In this species the anterior coxe do not differ in form from the same menums in Thyce, but the abdominal serments are much shorter, and are almost completely frex, requiring but slight force to break them asmoler. In all the other species the rentral segments are long and comnate, to absolutely the sane drogree as in Thyce squamicollis, being indicated only by feebly inpressed lines. The genns Plectrodes should therefore be placed in the Melolonthini, where it will constitute one of the transitions to the Macrophyllini.

2 Horn, Trans. Am. Ent. Soc., VIII, p. 146, and Pl. III, fig. 7. ${ }^{3}$ Ibir. 
females of such strongly developed forms as pulverea and IIarfordi. The antennal cluh is much shorter, more complact am oval. The anterior tilice are stouter and with more strongly developer external teeth. The restiture is very much shorter, fincr, and sparser, so that the general color is darker.

The species of Thyce are nocturnal, being abundantly attracted hy bright lights at certain seasons of the ycar.

T. spuamicollis Lec.-The female of this speeies is much lareer than the male, lut is almost precisely similar in vestiture. The pronotum in both sexes is very sparsely elothed with small, closely recumbent, squamiform hairs which are slightly denser along a narrow median line, as is usual throughont the genus; the lateral vitte are, however, not defnite. The name is therefore somewhat inappropriate. In the male the antennal club is nearly thee-fourths as long as the stem, and in the female only one-half as long as the latter, oval and more compat.

Although the npper surface is more than usually glabrous, the long dense silken pubescence of the under surface is as well developed as in any other species.

T. pulverea n. sp .- -Form elongate-oval, convex; elytra and alkmen dark reddish-brown; head and prothorax darker, piceons, the latter clotherl moderately densely with small robust recumbent hairs, and longer erect pubescence; elytra and abdomen very densely covered with minute, recumbent, squamiform hairs; remainder of the under surface with long very demst silky pubescence; mesosternal parapleure, hypomera, and exposed surface of maxillw devoid of long erect pubescence, but having whiter, dense and recumhent, squamiform hairs, a small imdefinite spot at the sides of each alxhminal segment also whiter and denser, remaining vestiture cinereous. Head widel than long; clypeus concave, truncate and very feebly sinuate in the middle, the angles slightly romnded, the base very slightly narrower; antennal chub as long as the stem; last joint of the maxillary palpus nearly one-half Ionger than the preceding together, and fully three-fourths as long as the antennal club, ratler robust, apex oblipne but not deflexed and with a small circular truncation, the groove very desp, wilening toward base, entire. Prothorr one-half wider than long; sides broally angulate, the angles rounded; basaI angles obtuse and rounded, apical obtuse but not rounded; apex very feebly emarginate, one-half as wite as the base, the latter broadly angulate, the angle broadly rombed; disk convex, finely, feebly and densely punctate. Scutelum white, more densely pubescent. Elytra nearly one-half longer than witle, widest near the middle, nearly one-third wider than the prothorax: siltes very feebly areuate; apex broadly simuate; humeri slightly tumir; apical umbones very forble; disk with the most feeble and indefinite traces of fine coste, very finely, feehly and denscly punctate. Pygidium one-third wider 
than long, feebly convex, very minutely and densely punctate and pubescent. Legs moderate; femora fringed with fine erect pubescence, the flat surfaces with very small, recumbent, squamifom laairs not very densely placesl ; tarsi as long as the tibise; claws arcuate, finely attenuate; tooth of anterior claw of anterior tarsi erect, near the base, slightly arcuate, stout and scarcely onethird as long as the remainder ; tonth of the posterior claw, less than one-half as large, projecting but slightly above the hasal carina; proportions in the other claws nearly similar, the tooth of the posterior claw of the him tarsi, on its onter elge, nearly one-fifth the internal length of the remaining fortion; corres jonding ratio of the anterior claw one-third. Length $22.0 \mathrm{~mm}$.

California (Los Angeles Co.).

The diagnoses here given are taken from the male; in the female of the present species the tarsal claws are rather smaller, the teeth more nearly equal, the greatest difference heing in those of the anterior tarsi, the posterior being almost absolutely ecrual.

In Thyce the fourth palpal joint is received at base in a broad exeavation in the apex of the rolust transvere third joint, and the latter in turn is similarly connected with the second.

The proportional length of the fourth palpal joint in pulverea is the same as that given for palpalis, but the two species can be distinguished hy the apparently denser pulsescence of pulveren, by the more rolust palpal joint in which the groove, according to the figure given by Dr. Horn, is differently shaped, and by the elaws of the posterior tarsi, in which the tecth are said to be very nearly equal in palpatis (Trans. Am. Ent. Soc., VIII, p. 147).

T. fossiger n. sp.-Form rather broally oval, convex, castaneous; liead and prothorax piceous; vestiture thronghont nearly as in melereu, but slightly coarser, and with the ereet hairs of the pronotum decidedly longer. Heud small, wider than long; clypeus concave, truncate; angles narrowly roumded; sides parallel, strongly arcuate; antemal club slightly shorter than the stem and but very slightly longer than the fourth palpal joint, the latter elongate, rather slender, the apex distinctly deflexed, and with the usual minute circular truncation, one-third longer than the three preceding together ; external groove entire, very narrow and deep, slinhtly enlarged near the base, and again moch more feebly so near the apex. Prothorax two-thirds wider than long; sides laterally strongly angnlate, the angle rounded; silles very feebly sinuate anteriorly, feebly areuate toward hase and nearly coarctate with the latter, the basal angles being very obtuse and broadly rounded; apical angles right, not rounled; apex very feehly cmarginate, one-lialf as witle as the base, the latter hroadly, feebly angulate, the angle broadly rom led ; disk convex, even, finely, feebly and densely punctate. Elytra two-fifths longer than wide and two-fiths wider than the prothorax; sides feebly arcuate; apex broadly angularly emarginate; humeri very feebly tumid; disk with 
rery feeble traces of costie, very minutely, frebly and densely punetate. Pygidium one-third wider than long, feebly convex, punctured, and very densely puhescent like the elytra. Legs noderate; tarsi as long as the tibite; claws nearly as in pulcerea. Length $20.0 \mathrm{~mm}$.

California (Los Angeles Co.).

This species is closely allied to the last, but differs in its shorter, more robust and flattened form, its shorter, more transverse prothorax with more angulate sides, which are more rapidy convergent toward base when viewed rertically, and in the structure of the antenne and palpi. The pubeseence of the elytra is more densely placed, and the pygidium more nearly vertical.

T. Harfordi n. sp.-Oval, convex, piceous-black throughont; vestiture yellowish-cinereous; silky hajrs of umler surface very long and hense; ablomen moderately densely covered with small robust recumbent hairs, each segment with a paler spot of denser prollestence at the side near the apex; maxille, hypomera, mesosternal praralenre, and metasternal epimera whiter and with short stout recumbent pulnescence; restiture of the elytra dense, the hairs robust, recumbent and rather long, sparser on the pronotum, the fine erect hairs of the latter long, dense and conspicnous. Heal small, lint very slightly wider than long; clypeus roncave, broadly, feehly sinuate, the angles narrowly rounded and the siles parallel and feebly arenate; antemnal chub robust, oval, mneh shorter than the stem and scarcely more than two-thirds as long as the fourth palpal joint; the latter greatly developer, more than onehalf longer than the preceding juints together, elongate, and but moderately robust when riewel laterally, with the lower edge straight, the upper hoally arcuate, the apex scalpellate, the lower foint of the apex not deflexed, and with an exceelingly minute circular truneation, having externally, an entire groove which is wille, elongate, elliptical, and extending fully one-half through the joint. Protherer two-thirts wider than long; sides rather strongly angulate, the angle rounded; sides near it straight; basal angles obtuse and moderately rounded; apex very feebly emarginate, scarcely one-half as wide as the base, the latter lroadly and rather strongly angulate, the angle broadly rounded; disk convex, very narrowly and feebly impressed along the median line, rather finely, feebly and densely punetate. Scutellum with a vely fine subdenuied median line. Elytric two-fifths longer than wide and nearly twofifths wider than the prothorax, with very feeble traces of broar coste, together broadly, angularly emarginate at apex when viewed longitudinally; sides farallel and feehly arenate; disk minutely, feebly and densely punctate. Leys worlerate; tarsi ahout as long as the tibix. Length $19.0-20.0 \mathrm{~mm}$.

California (Alameda Co.).

The elaws are nearly as in the preceding species, but the teeth are slightly more slender and acute. The pygidium is but onefourth wider than long. This speeies is rery distinet in its strongly 
dereloped palpi and correspondingly smaller, more robust and oval antenual elub; it was taken rery abundantly at night in the suburlss of Alameda, Cal., and is dedicated to an enthusiastic friend of entomological science-Mr. W. G. W. Harford, of Oakland, Cal.

DINACOMA n. gen. (Melolonthini).

Clypens concave, prarallel, sultrmneate. Nentum molerate, subquarlrate, concave. Naxille morlerate, the palpi well developed; first joint very small, narrow, obconical; second and third longer than wide, the former the longer, both obconical and obliquely truncate; fourth slightly shorter than the preceding three together, pointed, deeply impressed or excarated on its outer face. Lahial palpi very small; third joint ovoidal, obtusely acuminate, as long as the two preceding together. Labrum short, transverse, free, impressed in the midille. Antemne ten-jointed; mildle joints of stem subanchylosed, short; chul three-jointerl, very long and arcuate in the males. Anterior coxie transverse, but slightly prominent. Metasternal episterna moderate in width. Akrominal segments comnate, the sutures fine but not entirely olliteraterl, rendered distinct by the disposition of the restiture. Metasternum rell developed. Legs rather short and slender; tarsi short, the posterior much shorter than the tibie: claws morlerate, erenly and strongly arcuate, toothed near the lase, the teeth distinctly unequal.

The above characters indicate a genus intermediate in many characters between Polyphylla and Thyee. It is founded upon Thyce marginata Casey (Bull. Cal. Acad. Sci., II, 1) 39). The derp excavation of the fourth palpal joint, which is present in this genus in common with Thyce, is by no means confined to this group of genera, as it is a common charaeter in Diplotaxis, although generally less dereloped.

The characters agreeing with Thyce, resicle in the structure of the palpi and tarsal claws, and those which ally it most direetly with Polyphylla, are found in the greatly developed male antennal chib, and the short tarsi.

\section{TENEBRIONID.E.}

\section{EDROTES Lec.}

The four speeies of this genus may be separated as follows:Pubescence long and erect.

Pubescence more condensed in several narrow widely distant lines on each elytron; surface highly polished, very minutely and sparsely punctate, 
the punctures more dense-but still confused-along the more densoly pubescent lines, stromgly convex

ventricosus

Pubescence denser, withont trace of serial arrangement.

Lustre rather dull; form strongly convex; punctures dense, rery larpe and leeply impressed ; antenna rather robust

rotendatus

Polished, subdepressed above, more abruptly and strongly convex at the sides ; punctures small, sparse and perforate; antenuse longer amb very slender, less vapitate

nitiolus Pubescence very short, subrecumbent, not tefinitely arranged......ghobosus

E. nitidus n. sp.-Broadly-oral, llack; legs piceous; antenne dark rufous. Head distinctly narrower than the prothorax; median loke of plistoma strong, much wider than long, truncate, dilated at apex; onter face of mandibles very coarsely and densely punctate, the punctures distinctly separated. Prothorex fully four times as wide as its median length; apex browlly emarginate in eireular arc, the apical angles strongly, anteriorly produced and acute; sides very feebly convergent from hase to apex, extremely feebly sinuate towarl apex; base truncate; lateral acute edge olsolete except at the apical angles; disk finely very sparsely punctate in the middle, the punctures leeconing much larger, dense and subasperate laterally. Elytra willest just before the midlle; sides strongly, evenly arenate, the apex from above very broally ronmled; disk somewhat flattened above, nearly six times as long as the median pronotal length, and abont one-third wider than the prothorax, finely, sparsely punctate, the punctures generally separated by from four to five times their own diameters. Lengtl $7.5 \mathrm{~mm}$.

California (Mojave Desert, Kern Co.).

This species is quite distinet from any of the others; the puber. cence is long and somewhat coarse, evenly distributed over the elytra, a little shorter, sparser and coarser than in rotundus, and distinetly shorter, more matted and slightly coarser than in eentricosus; the latter is larger and nuch more minutely punctate.

E. globosus n. sp.-Very broadly oval and strongly convex, black throughunt; legs and antemne slightly piceous; pulescence very short, cinereous, abondant and depressed. Hect moderate; median lole of epistona wider than long, feehly constricted at base, the angles rounded and apex truncate; punctures of onter face of mandibles coarse, deep and dense, polygonally crowded. Prothorax very strongly transverse, broadly, very feebly emarginate in circular are at apex; lateral edges completely ohsolete and broadly rounder, the apical angles alone acute and prominent; disk polished, very finely and sparsely punctate in the midhle, abruptly coarsely, deeply and very densely so at the sides, the punctures mutually contignous. Elytra subglobose, rery strongly convex, rather coarsely, densely and evenly punctate throughout the disk, the punctures separated generally by rather more than their own diaueters. Length $5.5 \mathrm{~mm}$. 
Colorado (Greeley).

A rery interesting form, quite isolated ly reason of its small size, convex subglobose elytra, and very short subrecumbent pubesrence. It is one of the many interesting discoveries of Mr. H. F. Wickham.

USECHUS Mots.

Two species of this genus are now known; they may be dis. tinguished as follows:-

Nedian impressed area of pronotun fusiform, entire, more or less coalescent with the basal forea, the latter warrow and elongate; elytral punctures very large, widely sejarated in the rows; pubescence very sparse; color blackishpiceous

Iacerta

Median impressed area feeble, the sulseariniform sides nearly strainht and parallel, entirely olsolete just hehind the middle; basal fovea larger, rommled, always deep, distinct anl isolated; elytral punctures smaller, more closely placed; pubescence denser and rather longer, more densely and conspicuously nucleated in twelve small spots on the elytra; color paler, brown; size smaller.

nucleat us

The species above defined as lacerta, has been identified from the somewhat unsatisfactory figme given by Motschulsky.

U. nucleatus n. sp.-Of the same form as lacerta; pubescence pale thavate, rather sparse but denser and conspicuons on the elevated rilges, and in twelve spots on the posterior two-thirls of the elytra, disposed on each elytron as follows: one just before the centre, three in an oblique line at fosterior third, and two in a line nearly parallel to the suture, rather indistinct, and very near the apex. Heal small, rather coarsely and sparsely punctate. Prothorox as wide as long: posterior angles small, acute and prominent; base four-fifths as wille as the disk; surface finely tuberculate, each tubercle with a small lateral puncture bearing a stiff subreenmbent seta. scotellum extremely minute, trice as long as wide, pointed, slightly tumicl. Elytra with fine feeble coste, the intervals ileeply punctate, the humeral costa cery stmong toward base, the base also very strongly tumid at one-third the width from the suture to the sides, the posterior densely pubescent spots also slightly tumid. Length $3.0-4.2 \mathrm{~mm}$.

California (Humbolit Co.).

Occurs in great abundance in the IIoopa Valley, and may be distinguished at once from lacerta, not only by the characters given in the table, but by the form of the smooth and impunctate furrow which extends along the lateral edges of the pronotum behind the antennal excavations. In the present species this furrow extends nearly in circular are from the excarations, past the basal angles, 
and teminates at the rounded median basal fovea, while in larepta it is narrower and deeper, and terminates at the hasal angles; this character is comparatively constant. In lacerta the densely pulsesrent spots referred to as a prominent character of mucleatus, are also visible and in nealy the same positions, but they are always ferbler; the lensth of lacerta is $4.0-5.0 \mathrm{~mm}$.

\section{CaLo'TAX1 Horn.}

The form of the body in this genus somewhat resembles that of Coniontis, but is as a rule rather more broadly and evenly elliptical, the prothorax being more strongly narrowed from hase to apex. The senlpture is stronger and denser, and the setae, which are seldom prominent and nearly always recmbent in Coniontis, bere become much renser and more erect, in this latter respect resembling those of the aberrant Comiontis obesa Lec. The species are cutiroly confined to the small island of Guadalupe, off the coust of Lower California.

Most of the material before me has been recently collecterl hy Mr. (x. W. Dunn; the series is very extensive, amounting to about forty specinens, and indicates three species which may be distinguished as follows:-

Form liroarly elliptical; sides arenate.

Punctuation of elytra sparse, not muricate; surface shining; setit fine, easily removable

punctulata

Punctuation of the elytra distinetly nuricate; sete coarse, very fersistent, always present on the elytra

muricata

Forn narrow; oblong; sides parallel and nearly straight; surface dull, densely, coarsely muricate

angustula

C. Augustula n. sp.-Oblong, moderately robust; sirles prarallel and nearly straight; color above lark brownish-ferruginous, beneatl slightly paler and more rutous; legs concolorons; lustre dull. Head slightly wieler than long; median impression very small and nearly obsolete; punctures rather coarse, deepl, very dense, sparser on the oceiput; a small median area at the base impmetate. Prothorme transversely, strongly convex, fully twice as wide as the median length; sides feeloly convergent from base to alex and teehly, wenly arenate; apex broully emarginate; baso nearly straight, except at the sides where it becomes distinctly sinnate; basal angles distinctly proAnced posteriorly, right when viewerl laterally, not rounded, apieal very uarrowly so; disk very narrowly reflexed at the sides, coarsely, very dreply and densely punetate, nost densely so at one-fourth the wirlth trom the sides, where the punctures tend to coalesce longitudinally, more sparsely so near the mlges. Elytra at hase as wide as the prothorax; sides prarallel and nearly Axxals N. Y. Acad. Scl., V, Feb. 1890.-12 
straight for two-thirds the length from the bas, thence together rather acutely rombend behind ; disk transversely, strongly comvex, rather coarsely, densely and asperately punctate; interspares dull; phissence tine, rather long and dense. Length $7.5-9.9$ mm. ; wilth $3.8-4.7$ mm1.

Guadalupe Island.

The present species, which is represunted hy a series of ejght specimens, is immediately distinguishable fom the oflers ly its narow subcylindrical form, parallel and much more rectilineal sirles, and generally coarser promolal punctuation.

C. muricata IForn.-Represented hy a good series showing slight variation, especially noticeable in the size and ansity of the pronotal punctuation. The color varies from dark brownish-ferrogmous to piceous-black. One specimen differs in its more broadly oval form.

Leneth 8.0-10.5 mun.; width 4.3-5.5 mm.

C. menctulata 11 orn. - This species is represented by a homogeneous serjes of twelve specimens. The color varies from rather pale rufo-ferrnginous to piceous-black.

Length 9.5-12.0 mul.; width $48-6.0 \mathrm{~mm}$.

All the species of this genus have a narrow, more or less ineomplete, median pronotal line which is impunctate.

CaLUS Exill.

The gemus coulus is peculiar to the coast regions of California, and is foumd in abmance in the sand dumes which line the seashore. The species are somewhat closely allied, but searere to so ereat a degree as in colotaxis and Coniontis. They may be recognized by the characters given in the following table:-

Anterior angles of epistoma ristinetly prominent ; size large.

grossus Anterior angles not at all problucel, hroarly rommerl.

Form narrowly oral; pronotal punctuation very fine and sparse, unevenly distributerl

ciliatus

Form linally oval; monotal punctuation coarse and dee].

Punctures sparse arenarius

Punctures dense, evenly distributed, sometines semicoalescent.

globosus

These species vary considrably in size, but the greneral ontline and punctuation are fuite constant, so that there can be no diflieulty in identifying the forms here deseribed.

C. grossus 11. sp.-Form rather loroadly oval, very convex; dark castaneons to piceous-black, shining, minutely and sparsely setose above, more densely 
so near the sides, the latter ciliate with long erect seter ; under surface and legs but slightly paler. Heal much liroader than long, coarsely and densely punctate; sparsely punctate near the base, very convex, stromgly declivous to the clypeal suture, which is well marked; dypens feelly convex, very brably and strongly sinuate anteriorly; lahrum large, rufous in color: near the clypeal suture there are several coarse thavate sete. Prothorar slightly more than twice as wide as long, transversely, strongly and evenly convex; sides feebly convergent from base to apex, distinctly and evenly arenate; hast transversely truncate; angles-viewed laterally-very slightly obtuse ant sareely at all ronnled: apex strongly emarginate, fringed with flavate setie; angles evenly and rather narrowly rounded ; disk irregularly punctate; punctures rather sparse in the middle, warser and slightly denser near the sides; hase having a fine coriaceous or semimembranous margin. Soutellnm minute. Elytro slightly longer than wide, slightly more than twise ats long as the prothorax; sides parallel and feelly areuate for three-filths the length from the base, together thence evenly and somewhat paralolically rouncled behind; disk very strongly convex, finely rugulose, rather coarsely and not densely punctate: punctures evenly distribnted, slightly coarser and sparser than those of the pronotum, slightly asperate. Legs rather short and robust : tarsi slencler, first joint of the anterior proluced beneath the next three and the basal portions of the fifth. Length $8.8-12.5 \mathrm{~mm}$.

California (Monterey; San Pedro).

The distinguishing features of this species are its large size and peenliarities of pronotal sculpture. In ciliatus the punctures of the pronotum are fine and nearly evenly distributed over the entire disk, while in grossus they are slightly eoarser, and are almost entirely wanting in a broad hand, erossing the disk at about onethird its length from the apex, but not attaining the lateral matgins. This eharacter is ruite eonstant throughout a series of ten specimens which I have before me.

C. globosus Lee.-I obtained two speeimens of this species at San Diego, California. It may be distinguished from riliates and grossus by the very coarse and much denser pronotal punctuation, and the broadly oval form, heing even more dilated than grosets. From arenarius it differs in its much denser punctuation and slightly broader form.

C. aremarius n. sp.-Form rather broally and evenly elliptical, convex, shining, piceons to piceo-castaneous. Heul much broader than leng; : lypens broadly and feebly sinuate at apex; lateral angles broally rounded ; suture deep, straight; surface rather coarsely, densely punctate. Protherch widest slightly before the base, more than twice as wide as long ; sides strongly convergent from lase to apex, rather strongly arcuate; hasal angles slightly rouncted; apex broadly emarginate; disk convex, coarsely, sparsely and 
smmorlat unevenly punctate; punctures donser toward the lateral edges, where also they are intermingled with limer punctures. Elytra as wide as the

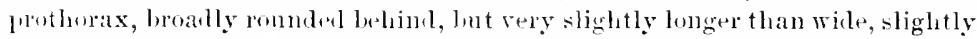
more than twice as long as the prothorax; surface convex, contsely, deeply, rather sparsely and asperately punctate: punctures slightly denser and more strongly granulose toward apex. Legs short. Length 6.5-8.5 mm.

California (San Pedro, Los Augreses Cu. 2).

This species somewhat resembles the smaller forms of grossus, but may be known by the hroadly rounded clypeal angles, these being narrowly rounded and distinctly produced anteriorly in that speciess.

C. viliatus Esch.-This species is rely abundant about San Franciseo. The series of thirty specimens before me indicates but slight rariability exerpt in size, the specinens ranging from 4.8 to $8.0 \mathrm{~mm}$. in length.

\section{MARYA.}

The following description will serve for the identification of the larva of Coplus ciliatus. The specimens upon which the deserip-

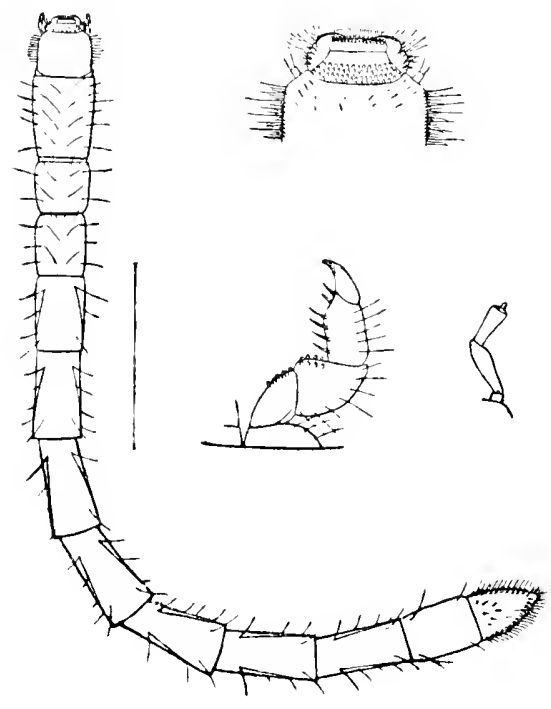
tion is based were found in a small sandy tract, in which the inago was more than usually plentiful, and undoubtedy represent the true larva.

Bodly very elungate, slenter, cylindrical. Surface shining, having a few very long fine setie, herissate with stiff fulrons setie at the apex and sides of the head, and beneath the latter and the thoracic segments. Interuments coriaceous, pale luteo-testaceous; leat, prothorax and anal segment subcormeous, darker, rufotestaceous.

Hearl as wide as the prothorax, as long as wille. Post-epistomal region slightly wiıler than long: sides parallel, nearly straight:

1 The figure on the lett represents the entire body: that to the right and ahove, the anterior portion of the hear, more highly nagnified. Of the two 
base transversely truncate; apex very broadly, ferthy emarenate in the michle three-tifths, raceiring the hase of the epistoma; surtiue shining, with a few erect dorsal setie, fechly and sparsely creased, laving two obligut lines of coarse ferble punctures in front of the midcle, am three in the widike near the epistomal margin; side margins bristling with erect setee. Epistona trafeztidal, transverse, foebty declivous; apex transwersely truncate; apical two-tifths glabrons, shining, very feebly rugnlose; basal threse-tiftes densely covered with small, robust, spiniform tuberetes. Lalomm stronery transwerse, truscate at apex, having a loose fringe of short porrected seta along the apex ; surfare lroally, very ferbly comvex, polished, glabrous, with a louble line of small, ereet, very robust spines near the apex. Mandibles not prominent, visible laterally; surface that; onter margin broadly bilobed; anterior lobe with an elevated margin; posterior with a donble line of coarse, erect spines Jiar the lateral naryin; outer tace hristling with erect, enarseseste. Antenne short, rather slender, four-jointed; third joint obonsical, shorter than the second: fourth small, subulate, enlarered and holbens at hase, the enbarrement enclosed by the apex of the third joint. Naxille well developort; hase very large and pominent. Maxillary palpi rather slender, not compersed, with three free joints, the basal being very short, hoan, and ancluylosed to the sulports; first free foint slimbly longer than wide, truncate at apex, slightly obconical; second fusibom, distinctly lomger than wide, lmoady truncate at hase and apex; third small, oblique, sides mearly parallel, twice as long as wide, two-thirds as long as tle second, apex truncate. Nentum longer than wide, ratler suall, trinstersely, strongly convex; surfite setose, granulose, also coarsely asperate; wular peduncle trapozoidal, well marked. Lignla slender, frojecting far beyome the nentum. Lalsial palpi snall, apfalrently of two joints, terminal slender, obligue, nuch longer than wide. Eyes wanting.

Pinthentr nuch longer than wille, slightly narrowed from apex to hase; sides

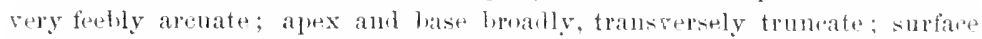
cylimblical, having a double row of four suall setigerous punctures near the midcle and extending fom base to apex; lateral suture inferior: under surfaces behind the coxie conical, ascending upward from the hase, shining, glabrous anteriorly, setose toward base. Lege far before tle middle, short, rolust, comfressed; coxie approximate, short; basal joint triangular, with a few sloot robust tubercles near the apex interiorly; second larger, triangular, with a double row of small tuluerentiform spines along the innur apex; thiml as loug as the secome, longer than wilk, with a row of loner, erect, very strong spines along the inner edge; terminal daw very latge, acminiate at apex.

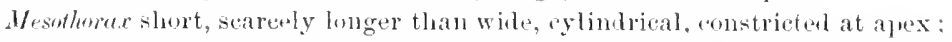
surface with a fow setigerous punctures anteriorly near the constrietion, and a nore widely distant row near the base. Lems at the modele of the segment, very small, rather rohnst. Surfice before the coxie carinate in the minlle:

remaining the one on the left represents the anterior lear with its coxa, and that on the right the antenna. 
that behind them convex at the siles, the convexities being separated by two divergent, inpresserl grooves.

Mrtuthorax longer than wide, nearly cylindrical. Legr: slightly behind the mirllle. Surfaee nearly as in the nesuthorax.

Aldominal srgments longer than wide, subcylindrical belind, more conical near the midlle. Each segment having on the flanks a tine, impressed, very obliquely tescending groove bxginning before the mildle; lines of juncture of the dorsal and ventral surfaces fitr inferior, straight, divergent from apex to base, strongly implresserl.

And seyment longer than wide, pointed, ogival, conves above, herissate with coarse, erect, fubous seta more sparse dorsally, with a few dorsal spines and a row of ereet spines parallel to and very near the erge extending from base to apex. Lower surface with two large tumid processes covered with short ereet spines, arranged transversely near the mildle and just before the anal orifice; the latter closed ly a small complicated fold which is not prominent; surface thence to the apex on a superior plane, smooth.

Length $18.0 \mathrm{~mm}$.; diameter $1.1 \mathrm{~mm}$.

COELMORPHA n. gen. (Coniontini).

Borly oval, convex, sparsely and minutely setose ahove, ciliate at the sides. Heat inserted in the prothorax to the midlle of the eyes, short, broal ; clypens romider at the siles, branly sinuate anteriorly ; mentum morlerate, obtralezoillal; maxilla broadly exposed at the sides; maxillary poll pi well dereloped, third joint suall, whonical, one-lialf as long as the secoud, fourth as long as the preceding two together, elongate, moderately dilaterl, eylindro-oveidal, olliquely truncate within at apex; labial palpi snall, third joint feebly dilated, cylindro-ovoilal, acuminate at apex; antennæ very short, incrassate, 10-jointerl, first joint short, inserted in front of the coarsely grannlated eyes and under the overhanging sides of the clypeus. Legs rather slenter, spinulose; posterior tarsi slenter, basal joint elongate; anterior tarsi scarcely as long as the tibie, first joint large, produced beneath the second and third joints; tibice not sensibly producerl exteriorly at apex, teminating in two short spurs and several small spinules. Ep piplenre broal, rapilly diminishing in wiclth toward the elytral apices which they attain. Seutellum minnte, triangular.

This genus is well distinguished from Colus by its 10-jointed antenne and broad rpipleure, also by the form of the prothorax.

The labrum is strongly retractile, and in three of the four specimens examined is completely invisible, the mandibles being fully exposed from above; the orman is indeed so fully retracted that merely the apex can be seen, even hy looking far under the elypens, which is separated from the mandibles by considerable intervening space. The fourth specimen is paler in color, and has the labrum protruded, showing this to be rather large and as usual broadly 
sinuate at tip. "The labrum is freely retractile in a great many other genera of Tenelrionilie.

The genus Carbs is a hiohly specialized form of the group roniontini, which embraces two distinct types, distinguisued primarily hy antennal and tarsal structure, and represented hy cerlus and Coniontis. The genus Colotaxis is the connecting hond hetwen the two sections, since it possesses the long slemder antenna of Coniontis, and, in a rudimentary degree, the tarsal structure of Coelus. Eusattus is closely related to Coniontis. Crelomerpha, on the other hand, while exhiliting a decided robtionship with Corlus, is a still more highly specialized and extreme form, and perhaps may be considered a transition toward a group or genus now extinct or not as yet discovered. This view is primeipally hased upon the broad epipleura and the form of the basal portions of the prothorax.

The prolongation of the hasal joint of the anterior tarsus, which. is most highly developed in c'ulus and Colomorpha, is rery moderate in Colotaxis and wearly olsolete in Coniontis, although in the later a distinct trudeney to prolongation may be perceived, the joint being very obliquely trumeate at apex. In Eusaltus the hasal joint is much longer and nore slender, and nearly every restige of the prolongation is lost. If, therefore, the group be arranged systematically in alecordanee with this character, the genera would stand in the following secpuence: Colomorpha, Cutus, Corlotasis, Coniontis, and Eusattus.

As a general rule in this group the hasal angles of the prothorax are prominent and produced posteriorly, and, although in Coclus and a few species of Coniontis this character is nearly obsolete and the hase of the prothorax alnost straight and transverse, we can eren in these cases clearly proceive the tendency to posterior prolongation. In Colomorpha, however, this character is completely reversed, for the hase of the prothorax heconies evenly and posteriorly areuate throughout its wirth, the basal angles bring hroally rounded and gradually coaretate with the sides.

C. maritima 1. sp.-Rather broally oval, convex, shining, piesous to pale ferruginous; under surfice and legs slightly paler. Ilend scahrous, hrorissate with coarse prect seta: antmuse very short, gradually ami stromsly incrassate, slightly compressul, scarcely two-thirds as long as the lieal; eyes very coarsely granulate. Protherer distinctly more than twice as wilte as long, broadly convex, margined along the base, which is broally and evenly arcuate, 
witlı a thin membramos lorder, lroadly emarginate at apex; sides feebly convergent from base to apex, distinctly and evenly arcuate; hasal angles hroadly roumded, apical much more narrowly so; disk with a few widely and irregularly scattered punctures in the midhle, which are coarse and excessively feebly inpressed; near the sides the punctures are much more dense, stronger and dintinetly seabrons or subasperate. Elytim connate, very convex; sides parallel and distinctly areuate fir three-fourths the length from the base; tegether hadly roumled hehind when viewed vertieally, acute with the sides straight when viewed longitmlinally ; disk excessively minutely smlogranu-

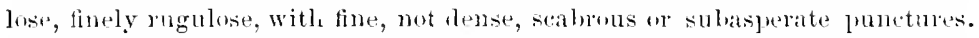
Conler surface molerately shining, finely, not densely aml sulaspreately punctate. Eppipleure nearly tlat, timely subruguluse and asperate. Lemgth $2.9-4.11 \mathrm{~mm}$.

\section{Inwer California.}

The specirs above deseribed is the smallest member of the group. Sereral specimens were secured by Mr. (x. W. Dunn, who informs ne that its habits are entirely similar to those of Coelus.

\section{ULOPORUS n. gen. (Tenelorionidre).}

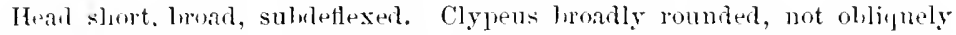
elevated at the sides. Eyes convex, molerate, coarsely faceted, extemling slightly further beneath than above, neither divided nor emarginate. Antenne inserted nuter the acote lateral elges of the clypeus, almont arljoining the eye, molerate in length, very slemer, the last three joints aloruptly litrger forming a distinct oblung club; first and second joints elongate-oval, slightly morr robust, the first slightly the longer and wider; third very slemder, three times as long as wille, rather distinctly longer than the fourth; eighth olconiteal, fully as lomg as wide; ninth abruptly much wider, subtriangular, wider than long; tenth obtrapezoidal, twice as wide as long ; eleventh as wille as the tentli, oval, slightly wider than long. Lakrum very short, strongly transwerse, truneate, the membranoms band separating it from the dypus fully as long as its exposed portion. Maxille large, greatly exposer and prominent; palpi well developerd; second joint long and sliglitly clavate; third short; fourth very large, strongly securitorm. Ligula short, indistince ; palpi rather small, wot very robust; thim joint rather longer than the second, feelly conical, twice as long as wille. Mrntum small, slightly elongate, distinctly narrowed from apex to base and supported on a moderate peduncle. prothwrax short, willer from apex to base, the siles coarctate with those of the elytra, the sides of the pronotmm margined with an elerated bearl, the apex and hase not margines, the latter fitted closely to the elytra. Prostermum short in front of the coxie, rather widely separating the latter, the process very largely developed belind the coxe, the apex angulate and receired in a deep impression of the mesosternum; develolment behind the coxe-near their immer margins-as great as before them in the same longitudinal line. 
Mesostermum very short; coxie widely separated, having a distinct trochantin. Metastermum moderate, the episterna noderate in wilth; posterior coxa alumst contignons, just visibly separated. Lews short; femora morlerately robnst; tibie short, having two sets of terminal spurs, one at the inner and one at the onter edge; spurs short am rather slender: tarsi morlerate in length, drinsely pilose beneath ; first joint elongate, penultimate very small, the hasal juint of the posterior abont as long as the entire remainder, the secomb olliquely and distinctly lobed beneath. Scutellum ratler small, strongly transterse, strongly romiled behind. Epiplenre molerate in willth, entire, horizontat belink, slightly bromer and fembly inflexed toward base. Body evenly elliptical, moderately and evenly convex.

The posterior mareins of the seeond and third ventral segments heing fuely coriaceous, determines the position of this rathro puzzling genus to be in the Tenebrionina, and the eyes being more prominent than the sides of the front, together with other characters above given, seems to indicate that it should be associated with the Diaperini, where for the present it may be placed near Platydema.

C. ovalis n. sp.-Evenly elliptical, molerately convex, somewhat strongly shining, rather densely pubescent, the pubescence very fine and extrenely short: liceons, legs and antemme dark brownish-rofons. Ifeed retractilu, very feebly, evenly convex, not in the least tuberculate, very finely and densely punctate. Prothora nearly twice as wille as long; apex abont two-thirds as wide as the hase, the latter transverse with a broal very feebly arcuate median loke: basal angles-viewerl laterally-nearly right, mot rommlel, apical rather broally rounded, not at all prominent; disk finely, very deeply and densely punrtate. Elytrc rather more than twice as long as the prothorax; willes arenate; apex broally rounded; surface very finely, densely punctate, with vaguely defined series of slightly larger, widely distant punctures, the series withont the slightest trace of impressed strie. Length $1.7 \mathrm{~mm}$.

Texas (Columbus).

This species is willely diffused throughout the States bordering the Gulf of Mexieo. I owe the specimen serving as the type of the above diagnosis, to the kindness of Mr. F. A. Schwarz, who diseovered it in eonsiderable abundance in the loeality indicated. 


\section{APPENDIX.}

\section{Contriblemons to the Auerican Termtopmlols Farva.}

The species recently described in these Annats nnder the name Termitorgater insolens, was the beginning of a series of discoveries ly Mr. J. Beaumont, in connection with eertain studies in the life habits of 'Termes and its allied genera.

The specimens of the species named alove, were found incidentally by Mr. Beammont in the galleries of termites, and were transmitted by him, together with the neuropterous specimens serving in part as the basis of a recent paper by Mr. P. II. Dudley, which has just been published in the Transactions of this Aeademy. When the attention of Mr. Beaumont was called to the importance of his discovery, a more careful and systematie search was instituted, resulting in the eapture of several very small specimens which have been placed in my hands for study by Mr. Dudley. These, as will be seen below, are found to represent two entirely new and rery interesting genera, and, in addition, a new speeies of Termitogaster.

The coleoptera associated with the termites aplear to be more specialized and more intimately connected with the life habits of their hosts than in the case with the more numerous mymecophilous species, and their taxonomy is more difficult to a corresponding degree.

If any generalization ean be made upon the little already known of these eurious genera, it would appear that, having become so profoundly modified from the more usual types,-as seen for instance in Spirachtha, which is one of the most remarkable instances of adaptive development at present known, - it may be legitinate to suppose that the nenropterous termites are an older type greologieally than the hymenopterous ants, whose coleopterons guests are generally less radienlly modified. This is of course under the supposition that the rapidity of erolution or alaptation has been approximately constant in the two eases, and that the coleoptera are cither intermediate in age between the termites and the ants, or that they are the most ancient of the three. The truth is, probably, 
that the more highly speeialized forms sueh as Spirachtha, Corotoca and Termitogaster, are very nearly contemporaneons in origin with the termites, while the less specialized forms suth as Philutermes and the genera here described, are intermediate in age between the termites and true ants, sinee the latter genera are scarcely nore modified than the majority of myrmecophilous forms.

\section{TERMITOGASTER Casey.}

In elytral structure the following species is an anomaly, and has searcely a parallel in the entire order.

T. fissipenuis n. sp.-Anterior parts slemier, compactly joined, parallel and subcylimbrical; abdomen strongly intlated; color pale brownish-flavate thronghond, the exposed membranous portions white, the elytra slightly piceous; integuments slightly alutaceons, very sparsely setose.

IIted scarcely as long as wide, not deflexed; sides short and parallel ; basal angles narowly romded; lase subtruncate, broully arenate, fitted into the apex of the prothorax almost throughont its width, the neck very widle; upletesurface coverel rather sparsely with minute sulasperate foints, very feetly convex, broally, ferbly impressed in the middle. Eyes rather large, almust evenly oval, very slightly longer than wide, convex and distinetly prominent, finely laceted, longer and slightly more prominent than the tempora. Antenme ahout two-tifths as long as the body, rather slender, cylindrical, Ionsely articnlated, strongly geniculate; hasal joint suherual to the next three combined; two to four decreasing rapidly in length, the latter just visilly longer than wide, obtrapezoidal, the sirles but very feebly ollique; four to ten almost exactly similar, the ninth as long as wide, the tenth just visilly transverse; eleventh cylindro-oroiktal, pointed, as long as the two preceling; all the joints sparsely sitose and also finely pubescent, more densely so toward apex and ahmost glabrous toward hase; basal joint inserted in a small romided entirely dorsal fovea, arljacent to the antero-superior margin of the eye. Front before the anteme alvanced and strongly arcuate at apex, the surface just betore the apical margin elevated in two broad aplroximate cariniform tubereles, inmediately in arlvanes of which the surface is very short and strongly declivons, the apical margin with a very minute deej rounded emargination, having the sides in the form of line carine and with the apical projections extremely fine and acute, but not greatly advanced. Lebrum distinct, transverse, broally, strongly sinuate at apex, with the surface strongly impressed opposite the sinuation, separated from the front ly a membranous sheath. Hentum large, longer than wille, breatly impressed : apex very slightly narrower than the base; sides parallel. Lignla very short, membranous, sinnate at apex-viewerl dorsally-with a short eylindrical porrect process projecting from the bottom of the sinnation, the paraglosse alparently entirely obsolete. Labial malpi very small, slemler, the three joints decreasing nuiformly and rapilly in width, 
cylindrical, the last two subequal in length and together but slightly longer than the first. Wariller large. greatly exposenl aud prominent, expecially towald base, the hasal plate nut in the least spinose: outer lobel well dexelopes, lunate, cormeons, with the apex acnte, the imner edge fringed with moderate set:e: inner lohe not made ont. Mrerillary falpivery large, conspicuons. sparsely setose and irregular ; lasal joint small, rather bonger than wille, distinct ; seond extremely asymmetrie, slightly transverse. feeldy comber on the onter side, desply excavated on the immer ; third longer than wide, longer than the secomd, ovoidal, grabually pointed, convex on the muter side, bromby excavater on the imer, the fourth joint minute and spiniform, not ohlinge. Mandith's moderate, not made ont, closed in the type.

Protherer slightly willer than the heal and a little wider than long; sides nearly straight and parallel; apex broally strongly arenate and ronuded into the sites, the apical angles olsolete; hase truncate throughout the width am very tewhls atruate, the hasal angles nealy right and rery narrowly rommed. Prmotmm extremely fetbly, erenly conrex, not impressed, shining, excessirely minntely, sparwy, mbasperately punctate, each pint hearing an excesively minnte erect gale sutiform hair; disk with two rery widely distant subhasal setar, and four, foming a trapezoid, in the apical halt; viewerl laterally the flanks are natrow and purendicular, scalrous, the lower odge sinuate just lethind the leflexed apical angles, which are acute and continued in tront of the coxe by the extremely short and ahnost lamellate ante-coxal prosterual piece. Prostermm extremely short, not one-third as long as the promotmin. futrior conce very long, loosely attathed in the large mumbranons cavities, finely seabrons, almost ghahrons; femora lomg, the uldere mige strongly arenate, the tibie as long as the femora, coarsely, rather densely setose within, with two external rows of long slemele witiely-spaced sotitom spines. The disk of the pronotnu in the male is very slightly whier, and more distinetly longer, than the heal; in the female the head is quite noticeably smaller, with the tempora not quite so prominent.

Mesithrue moderate in length. Scutcllum rather large, transverse, ogiral, in large part cocered by the pronotum. Proplena of the mesosternm timely seabrous, large and well dereloped. Corm very large, long, obrique, contignous; trochanter's moderate, with a short outuse dentiform process within, the femora rafinly narowed near the point of attachment on the trochanters, the tibie sinilar to the anterior but less densely setose within.

Mefastermum well developesl. Elytre equal in length and hasal wilth to the correspoming dimensions of the pronotum; sides straight and parallel, each elytron distinct, the two sefarated by an interval, which at the apex is equal

1 In insolens the outer lobe is shorter, wide, arcuate, the apex truncate internally and bearing a low of short stiff spinules; the innel lobe is very short, adjacent to the onter, the base oblinuely corneous, the remainder semimemhranous, the apex with a row of short spinnles almost continuous with those of the outer lohe. The disposition of the lobes is somewhat similar therefore to that of Iomalota and Enryusa. 
to their own with, the sides of the interval straight and foelhy convergent anterinly, abruptly terminating at a print just hehind the scutellum, where it is alunt one-lialf as wide as at the ajex : surface coasely am stromgly retion-

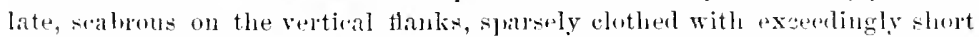
elect setae, and each with two long setie near the inner margin, one near the base and another behind the middle; flanks perfectly devoid of true aliplenre. Epristeme large, triangular, very wide behind, hnt covered by the elytra before attaining the humeri. Core with the inner portions lasge, porrect, contignous, longer than wide, truncate at apex, with the surface broadly convex; trochanters large, simple; femora irregular, the upler erlge lowoally angulate just beyond the middle, the edge thence lubally incurvate in cirenlat segurnt to the point of attachment; tibie sparsely setose within, the spinose setae of the two external rows stronger. Himd wings wanting.

Abdmen witl six segnents, wilely intlated, in the female three times as wide as the elytra, with the sides strongly arcuate, in the male very slightly nardower, with the sides slightly straiglitej in the middle; integmuents in great part chitinoms, the white membanums portions but sliglitly expused; npper surface feeluly convex, each segment above and heneath with two transverse rows of setat; lateral border deer and strongly reflexed; lower surface very comvex, the sutie longer.

Legs rather long and slender. Tilin parallel, truncate, withont temuinal spurs. Tarsi 5-jointed, rather long, slightly compressed ; first joint as long as the entire renainder-slightly shorter in the anterior;-fourth anchyluser to the fith.

Lenughth $2.8 \mathrm{~mm}$.

\section{Colombia ( Panama).}

The ahove deseription is rather comprehensive, and includes generic as well as specific tharacters in order that the mumerous differential characters distinguishing it from insolens may be marle more evident. The differences reside mainly in the strueture of the elytra, front, convexity and prominences of the cyes, and irregularitiss of the trochanters and femora; in insolens the elytra are absolutely commate, and soldered so completely together that the suture is only indicated by a very feebly impressed line, _as great a divergence from the corresponding structure in fissipennis as conld well be imagined. In both, the maxillary jalpi are exceedingly irregular, but in the present species they differ greatly from those of insolens. The fact that the tarsi, antenne and ceneral habitus are similar or parallel to those of insolens, seems to indicate that they should not be generically separated, but the great and radical differences show at the same time that the gemus is probably one of great age in a geological sense.

In the male, the sixth aldominal segment is evenly emarginate 
throughout its width in hroad cirenlar are, while in the female the same segment is angularly prodund in the midale for a short distance. The remarkible modification of the palpi and legs is not a sexual peculiarity, being dereloped to precisely the same extent in the male and fumale. The same remark applies also to $T$. insolens; in this species the sixth segment is truncate in the male, and forbly, roundly lobed in the midlle in the female. In insolens the two mandibles are similar; they are lather slender, foebly arcuate, having internally just behind the middle a large oblinue syuarely truncate tooth; the portion beyond this is very slender and has, just before the apex, a small oblique tooth.

ABRo'TELES n, gen. (Alencharini).

Budly rather rohust, suhparallel; abdomen slightly inflated.

Heud nearly twice as wille as long, porrect, feebly convex; sites very short, parallel, feebly arenats; hase inserted slightly within the frothorax, not in the least constricterl; hasal angles not exposed; apex brnally arenate between the eyes, the latter rather large, finely faceded, not at all prominent, ronmiterl, shightly angulate above. Antemuf inserted in small forex on the rertical sides of the front allacent to the middle of the anterior margin of the eyes, and just abore the base of the uandibles, 11-jointerl, very robust ; first joint olronical, longer than wide; joints two to eleven forming an elongate cylindrital chub, strongly tapering near the base and more fechly so near the apex, joined by a narrow point of snpport to the truncate apex of the basal joint at a point near its lower margin, the joints separated hy transcerse sutures, apparently mobile bnt each inserted far within the next precoding, subequal in length, about one-third wiler than long, except the second which is obconical and bat slightly wider than long, the third which is shortest and about twice as wide as long, and the eleventh which is pointerl, slightly compressed and as long as the two preceling. Epristoma membranons, short, broarly trapezoilal, the apex broadly sinuate, not separated from the front by a suture, the chitinous portion of the front alruptly terminating at a broally incurvate line between the bases of the antenne. Lahrum well dereloped, prominent, twice as wide as long; siles and apieal angles tontinuously roumled; apex with a small very deep median sinuation. Mumbibles very short and stout, arenate, slencler toward the acute apex, apparently with a large obtuse internal tooth at the michle. Mentum large, slightly longer than wide; base and sirtes continuously rounded; sides slightly convergent in apical third and nearly straight; apex truncate; surface tlat, corneous in basal two-thirds, transparently membranous in apical thirl, the line of demarcation sinuate and without visible suture; chitinous fortion with two long erect setre near the centre, arranged transversely and nearly trisecting the wirth. Ligula molerate, membranous, with a short rounder simple median process, the paraglosse small, 
roumled and adranced as far as the apex of the metian lohe. Lathed palpi 3-jointed ; basal joint slightly longer than wide, cylindrical; secoms much shorter, very sunall, cylindrical; third longer, subulate. Mharille molerate, not exserted; loles small, the outer enveloping the imnes, not hooker at apex, ciliate. Maxillery palpi nearly of the usual type, rather slender ; secomd and third joints subequal; fourth subulate. Under surface of heal without trace of lateral carince.

Prothorax rather short. Promotum transverse; alex truncate; base just visibly arcuate; siles feebly areuate and just perceptibly convergent trom luse to apex; hasal angles nearly right and extrmely narrowly roumderl; flanks rather shallow, very strongly deflesed, the lower erlge straight, the apical angles_viewed laterably-more broadly romiled than the bisal. Mypomoro very strongly inflexed, almost parallel to the pronotal tlanks. Prostromm extremely short before the coxe, the latter large.

Mesothorax short. Scutchum triangular, strongly transverse, the apex exposed. Hesostermal parapleure suall, the epinera but partially dereloped, leaving a considerable extent of membrane exposed adjacent to the elytral humeri. Cocre moderate and not greatly exserted, the cavities confluent.

Metathorar longer. Elytru transverse, truncate at apes, as wide as, and with the suture subequal in lengtl to, the pronotum, not comate; suture not leaded; hind wings apparently not well develolind; apical edge slightly inflexed and membranous; flanks witlont true epipleure, not learled. Metasternal pristema very wide behind, their immer lins taugent to the elytral liumeri. Coxce rather uarow, exterding to the very wicle ejisterna, contignous.

Abdomen sliglitly wiler than the elytra, the sides feetly areuate, consisting of six segments. Upper surface flat, each segment with a single apical series ot long stitl setie; border wike, but not inclined. Lower surface convex, the setre shorter and not definitely arranged.

Legs short and robust. Femor oblong, deeply excarated along the lower edge toward apex for the reception of the tibice, the latter mearly equal in length to the fenora, larallel, truncate or slightly roumled at apex, more fisely pulnescent, entirely dernit of terminal spuss or spinules, bnt having several very long stiff setre along the external edge. Tarsi sloort, rather robust, pubescent, 4-jointed on all the legs, the first joint of the posterior as long as the next two together and exual in length to the fifth. Umynes very small, arenate. Anterior tarsi with a better defined tuft of long hair beneath each joint.

There is no described genus known to me with which the present ean be compared. The robust compact cylindrical antennae are charaeteristie of a number of termitophilous and myrmecophilous genera, lut none of these appears to have the posterior tarsi fourjointed, as they very elearly are in Abroteles.

A. Beaumonti n. sp.-pale piceo-testaceons; abdomen flavate; integuments polished, not perceptibly punctate. Head very finely, sparsely pulbes- 
cent ; antenne slightly shorter than the hean, fonotum and elytra conlined. Promotum very slightly less than twise as wide as long, very feebly, transversely convex, not distinctiy impressed, with a series of wide-spaced erect seter along the a pical margin and thence along the sides to the middle, where they abmutly terminate; disk extremely sparsely pubescent, the hairs snbrecumbent, rely ninute toward the middle, longer and stiffer toward the sides, and posteriorly to basal fifth, where they abruptly terminate in a transverse line parallel to the lase; surface thence to the base glabrous, except a few minute hairs along the fine paler semi-enriaceons posterior edge, extending anteriorly along the sirles to about the middle. Elytra polished, depressed; sides straight, feehly divergent from base to apex, almost exactly similar in form to the pronotum, and aluost inperceptibly longer, at base slightly narrower, very sparsely elothed with rather stiff subreenmbent hairs, evenly but not regularly disposent. Aludomen distinctly longer than the anterior parts combined. and distinctly wider than the elytra; sides arcuate; ulper surface almost glabrous, excelt the wide depressed border which is very tinely and indistinctly pulsescent ; miler surface almost completely glabrous in the midhle, bnt rery finely pubescent laterally. Length $1.8 \mathrm{~mm}$.

\section{Colombia (Panama).}

In the nale, which appears to be much more alumdant than the female, the sixth segment is very broadly rounded behind, the middle of the apical margin truncate or excessively feebly incurrate; in the female this segment is broally and feelsy produced in the midnle in a wide broadly rounded lobe. The elytra also appear to be rery slightly shorter in the female.

In dedicating this species to Mr. J. Beaumont, I wish to acknowledge a strong appreciation of the patience and scientific zeal on his part, which have led in so short a time to a decided adrance in our knowledge of the interesting and apparently greatly dirersified ternitophilous fauna of Tropical America.

PERINTIUS u. gen. (Aleocharini).

Bolly nearly as in Myllana, densely and very minutely pubescent.

Head small, strongly deflexed, deeply inserter in a rounded apical emargination of the puthorax; portion behind the antemue much wider than long, not in the least constricted at base, the latter covered by the pronotum ; surface evenly, mokerately convex. Ey's large, finely faceted, minutely, rather densely setose, not prominent, ronnded, oceuyying nearly the entire sides of the hear and, in repose, partially ovellapperl by the pronotum. Antenme inserter in small fovere adjacent to the anterior margin of the eye on the alruptly inclined and concave apical portion of the front-epistoma-which is cornesms and separated frum the front proper by a transverse finely cariniform line, which is sinuate behind each fovea, and anteriorly arcuate and more 
alvanced in the midile, abruptly terminating at each side at the anterosuperior margin of the eye; they are 11-jointed, molerate in length, very strongly thattenerl; when viewed on the compressed sicle the sides are parallel as far as the fourth joint, thence narrowed to the hase of the third ; first joint rather slemler, Jonger than wide; second slightly narrower, much shorter, sulwylindrical, longer than wide; third obconical, slightly longer than wile, compressed; fourth abont as long as wide, obtrapezoidal; remaining joints subernal, truncate at base and apex, with the sides almost parallel, in close contact thronghout the width, rather more than one-half wider than long on the compressed side, and very sleniler, fully one-half longer than wile on the edge, the eleventh joint slightly shorter than the two preceding. Apical margin of the epistoma membranous, truncate, the labrm large, prominent, wider than long, with the apical angles broadly rouncled, the apex with a small feeble median sinuation. Mamlibles small, areuate, acute and simple at tle inmerliate apex. Mentmm large, equilatero-triangnlar, with the sides straight; surface tlat; apex very narrowly truncate; basal lialf corneous, apical membranous, the diviling line feebly sinuate, not at all impressed. Ligmln molerate, wider than the apex of the mentum, rather long, with a prominent deeply hifid median process, the paraglosse not well developed. Lubial pulpi robust at lase, the joints rapilly decreasing in thickness; third subulate. Mroxillo moderate, teebly exserted; lobes small, ciliate. Mrexillary palpi of the usual type, rather slender; second joint shorter than the third; fourth sulmate. Lower surface withont trace of infra-ocnlar ridge, the eyes approaching within a very short distance of the luccal carity.

Prothorar strongly developed dorsally, very feelily so ventrally. Promotmm large, strongly, transversely convex, molerately narowed from base to apex: lasal angles evenly, somewhat ubtusely rounder and slightly produced posteriorly, the lase being incurvate and subtruncate between them. IIyomra very wide, extrenely strongly inflexed, parallel to the strongly inclined flanks of the pronotinu. Prostrmm very small, extremely short in front of the coxie, the latter large, conical and convex.

Mesothrax short. Sintellum invisible, completely enncealed by the greatly overlapping free erge of the pronotum. Nesosternal side-pieces ample, entire; coxit large, contiguous.

Wetuthor molerate. Elytim truncate, apparently connate, very short and transverse, as wile as the prothorax, but slightly more than one-half as long, transversely convex; tlanks stromgly inclined, the eppleure very strongly inflexed and almost parallel to the flanks, deep; suture very fine lunt distin.t. Metastemum wide; episterna narrow, parallel; coxce molerate, contignous, Iamellate and transverse laterally.

Aldomen at hase slightly narower than the elytra. conical: silles rapidly convergent to the acute alex and nearly straight, consisting of six seguents which ase nomberate in length, each having a single transverse series of loner widely-spaced apical setie above and beneatl. Upler surface monterately comvex, the border narrow, normal, moderately deep. Lower surface mors strongly convex.

Axwals N. Y. Acad, Scl., V, Feb. 1590-13. 
Lrgs short. Fomorn stont, the tlanks produced beneath slightly at apex, forning a channel for the partial reception of the tilise. Tibic slemder, short, "ylindrical, truncate, without teminat spors or spinules and devoid of long external setw. Tursi short, slender, cylindrical, densely pulnescent, alwout two-thirds as long as the tibie, 4-jointerl on all the lears; first joint of the posterior distinctly longer than the next two together and a little longer than the fourth. Cingues small and slender.

This gemus is also somewhat isolated, hamonizing but remotrly with any of the more usual forms of the great and composite group 10 which it is assigned. The extraordinary compressed, alnost taje-like antenne, deepl flanks of the pronotum and clytra, which extend far below the plane of the lower surface, very short elytra, long conspicuons tactile sotie, and four-jointed tarsi, form a combination of characters for which it is diflieult to find a fitting place in the series.

The sexual characters, also, are very singular. In the male the apex of the abdomen is not nodified beneath, the sixth segment heing evenly rounded hehind, lut dorsally, the posterior edge of the first seguent is strongly cmarginate in middle fourth, the bottom of the emargination heing transverse. In the female the sixth segment is rounded as in the male, hut the basal segment is entire.

P. Dudleyanus n. s1.--Piceons; alkdomen sliglitly paler; mder surface, legs and antemise pale brownish-tlavate; surface lustre alntaceons, the fulesconce oxcendingly short, fine, dense, slightly cinereons and conspicuons, the long tactile setat very conspicunus, these consisting of six longitulinal series on the pronotum-counting those of the lateral exlges-and a transverse saries just before the mirlle of the elytra, the latter being simply the terminal setre of the pronotal series, the setre of the abromen lieing a further continuation of the pronotal series. Ifad small, only the occipnt visille from alove, the anterior portions of the body appearing to be semicircularly romded, nuch less than onte-lialf as wile as the lase of the prothorax; antennie about as long as the head and prothorax together. Prothora. nearly one-half wider than long, natrowerl from lase to a exex, subconical ; sides very feebly arenate. Elytre about equal in width to the prothorax, strongly transverse: sides parallel and nearly straight; disk scarcely perceptibly more than one-lialf as long as the pronotum. Aldomen distinctly longer than the anterior parts combined, conical, acute. Leng $\mathrm{h}$ 1.4-1.7 mm.

Colombia (Panama).

Taken in considerable abundance by Mr. Beaumont. A grood selies has been given me by my friend Mr. P. II. Dudley, to whom it gives me great pleasure to dedicate this very interesting species. 
In glancing through the plates of Schioblte's splendid work on coleoplemens larva, we camnot resist drawing a few minor gemeralizations with loforenee to the great persistency of larval tyo which

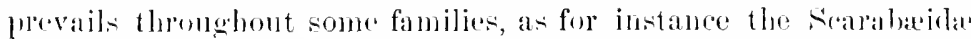
and Tomolnionirlae, and the enolmous dirersity of type exhibited hy

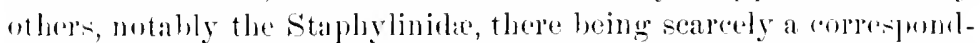
ing diversity of imaginal tyle in the latter, although the inago is undoulderlly more beterogeneons than in either of the fanilies before mentioned. Inedentally we may perhaps be warranted in infurring that the scarabeidae and Tenebrionide, being more homogeneous and lesin diflerentiated in both larval and perfect stawn, are more rerent in origin than the strongly differentiated staphylinidar ; this is of comrse under the general prenise that multiplication of species is due to differentiation from fewer and more synthetic ancestral forms, although I am aware that Ir. Sharp holds that there is but slight evidence of such dirergence in the Iytisciclae. The truth is, probably, that the Staphylinilae constitute one of the most ancient trpes of coleoptera.

Regarling the eurions olject described below, it ean only be said that if it he staplyclinide, as there is some reason to sulpose, it will add another notable clement to the hetrogeneity characterizing that interexting fanily. Or, ronversely, its wide departure from the usual types of coleopterous larve will not, of itself, be an abstacle in the way of its assignment thereto. In this comnertion it is desiralle to nake tha following observations:-

1. The specimens were reeeived in two small tubes which, in one instance, contained besides only specinens of Termitonaster insolens, and in another, only Perinthes Dudleyamms. Mr. Beaumout seens to have been rareful to isolate his material, and it may the very safely assumed that the lave and heetles were taken together from the samb nest.

2. As far as its gemeral nature is concerned, I believe it to be coldopterous, although in antemal structure it is exceedingly exceptional for that ordere, being approached in this respect, within my knowledge, only by Cyphon. The dense squamose vestiture, enormons develupuent of the labial palpi and tarsal structure are also exceedillegly pereuliar.

3. Assmming it to be coleopterous, I and quite convinued that it rannot loe related in any way to Termotogastere, but thiuk that it

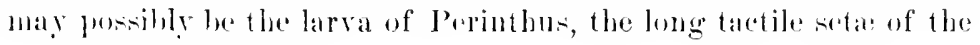


upler surfice, as wrll as the conical and attenuate form of the aludomen, leminding us foreibly of $P$. Indleyarms.

Whateref future investigation may prove it to be, the following short deseription will serve to make known its most salient characters:-

Body fusiform, whtnsty rommed in front, attenuate and acute behindnearly as in lepisma, hut with the aledmonen more strongly and erenly conical, -compex, and coreder densely alwse and beneath with large pearly-white rosely recmubent strigose seales; integuments soft, membranous and pure

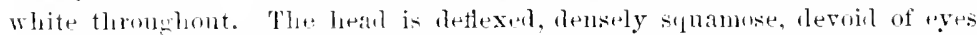
and ocelli, having the antemue inserted on the front. approximate and $x+p^{\text {ra }}$ rated by a nalrow very teblo ridge, very peresptibly attemuate from base to alex, yather nore than one-fourth as long as the bory, eylindrical, 12 -jointed, the sulbuas joints short, closely approximate or subommate, the outer more ehongate and neme lonsely articulated, the joints annulatel with fine imperessent grooves, one to three in number. The maxillary palpi are moderate in length, cylintrical, 4-juintel. the last joint longest. The labial palpi are larere and

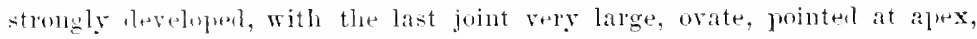
roncave withent and convex within. The three seguents of the thorax are histinct. the thanks thin and rescending very noticeably below the plane of the lowel surface, the promotum as long as the mesonotum am metanotum combinal, wath of the dursal segments, including these of the thorax, leatring a transterse apical series of long widely spared tactile sete. The six legs are short, the coxie larese, contical, the femora rolmst, the tiliae rolust, eylimirieal, each with a latre terminal spur ; tarsi cylimbleal, composerl of two joints, the stomet twiet as long as the first: claws two in number, minute, arenate. The alodominal stumplits are ten in number, comting the small terminal segment, which lears a suall axial anal style composet of seven or eight joints: there are alon two-hut lateral anal stylets, compeset of a few clowely connate joints: the sutures letwosn the abrominal segments almust concealed by the dense vestiture. The length of the largest specimen exanined is $2.5 \mathrm{~mm}$, the greatest wilth leing $0.8 \mathrm{~mm}$.

One of the most remarkable structures distingnishing this larra is a rery lare fleshy appendage projecting from the lower surface of the abdomen, just behind the fifth segment, and nearly as large as the entire abdominal vertex beyond it. It is mobile about its point of at tachuent, elongate-oral, longitudinally and very narowly dirided thromghut the length, forming two thick elongate cylindroconieal lobes, which are densely, fincly pubescent, and provicled in ardition with long sparse seta, especially at the sides. The lohes are divided by transverse sutures into six segments, of which the three basal are rery large, together occupying four-fifths of the length, the three last small and composing the rapidly acminate 
portion; at the apex of each there is a rery short two-jointed styliform process. This orean is held in repose in a long rery dere exearation extending through the last four or five aldominal serments, $\therefore$ that when at rest it is not distinctly noticeable, its lower surface being eontinuous with the lower surface of the aldomen. It ia]prarently an auxiliary organ of locomotion, analogous te the infiaapical process characterizing many well-known staphylinidr lante; hut no such development as this has to my knowledge been ob-rored before.

Another larva-like olject, possibly of a coleopterous nature, wat inclosed in the tube containing the only specinens of Abroteles Beaumonti which were olstained, but I an very douhtful of it connection in any way with that speeies; it sems to be too larpe and wile and to contain more matter than would sulfice for the hods of the insect mentioned.

The large well-developed eyes, large seeuriform maxillary palpi, and elongate 5-jointed tarsi are wonderful charactris, alnost irreconcilable with what we know of coleopterous larve. The following description will perhaps serve for its future recognition :-

Boily evenly oblong-elliptical, depressed, with the upper surface hroally, teetly convex, broadly roumled lefore and behind. The npler surface is strongly reticnlate, alutaceons, pale brownish-piceous in color, and corered sparsely with very short robust spinose sete. The head is deflexed very strungly, reposing upon the under surface of the prothorax; it is rather large, triangular, the eyes at the sides conrex, large, and composed of many coarse convex facets. The antemne are inserted in very large widely distant foret on the front before the eyes, and are defective in the only speeimen; there are four joints remaining, the onter deeply anmlated, and showing that there has leen at least a terminal process hroken therefrom. The epistoma is large and separatel by a distinct broadly sinnous suture. The labmu large, sulnqualrate. Maxillary palpi well develoged, with the last joint very large and strongly securiform. The six legs are alout equal, rather long and well developed; coxa $v \in r^{\prime} y$ long, conical, obliquely recumbent posteriorly, the pusterior large flat; femora elongate, flattened; tilise long, cylimlrical, with two strong well-developer distant teminal spurs; tarsi long, very slender, cylindrical, the posterior nearly as long as the tibie, distinetly 5-jointed on all the legs, the first and fifth joints elongate, the interumediate short; claws two in number, well developed, areuate. The pronotum is much wider than long and longer than the other two parts of the thorax combined, it is finm camalicnlate in the middle throughent the length. The abounem comsisto of 


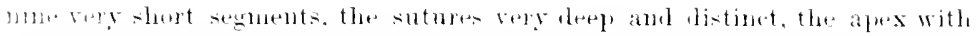
two grate of sery shert anal stylots, hut without unelian style. Jengeth 2.4 IIII. ; wirlth $1.0 \mathrm{~mm}$.

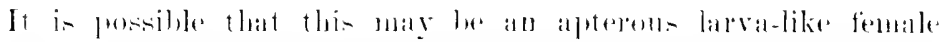

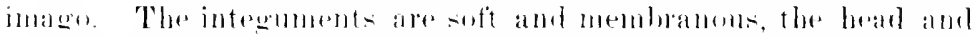

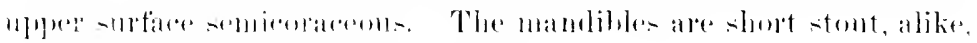

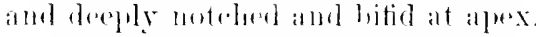

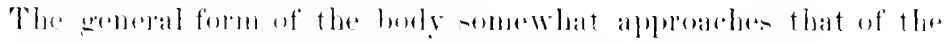

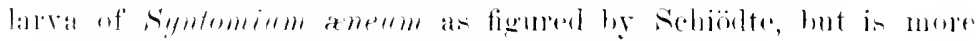
Mneate and with the -ide- more paralled. 







$\begin{array}{ll}\text { QL } & \text { Casey, Thomas Lincoln, } \\ 573 & 1857-1925 .\end{array}$

$\mathrm{C}_{3} 1$ Coleopterological Ent. notices. 


\section{How

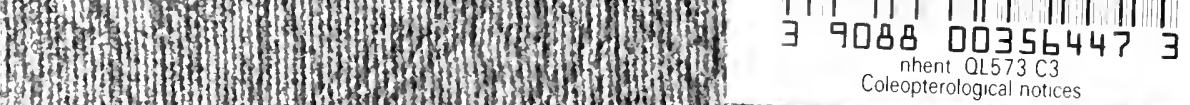

How H.

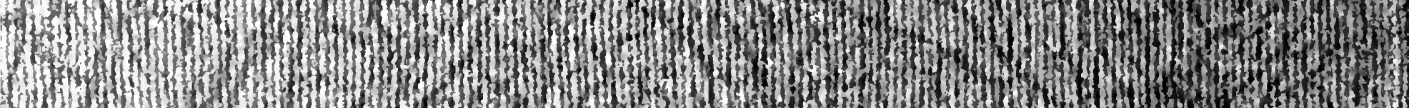
1 m.

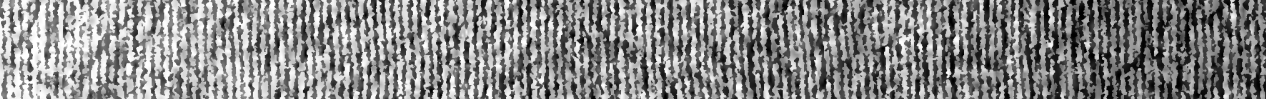
(1)

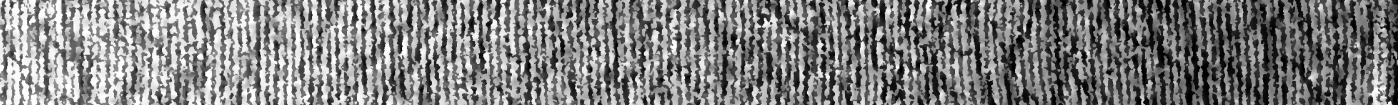
17mom 3.1.7. 4.1.

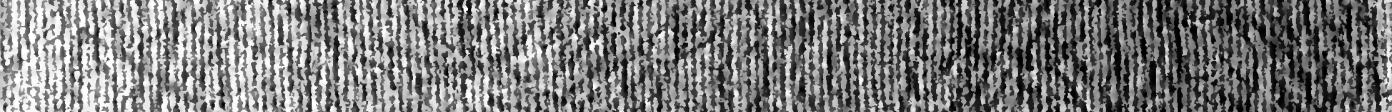
1. 1 mon

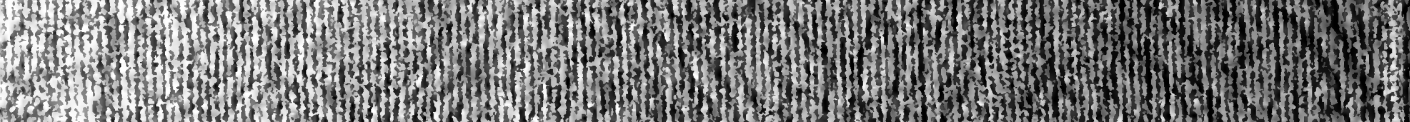
n.

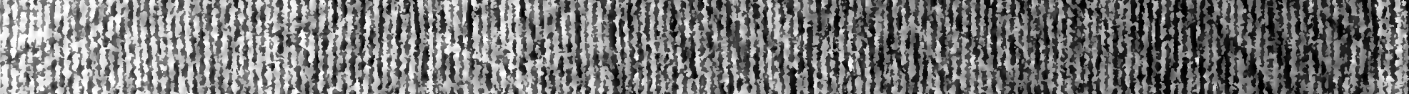
37.

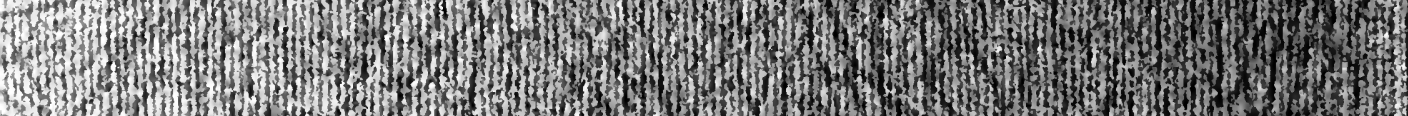
3.1. nonm

Hom Whin 4.6. Whom How

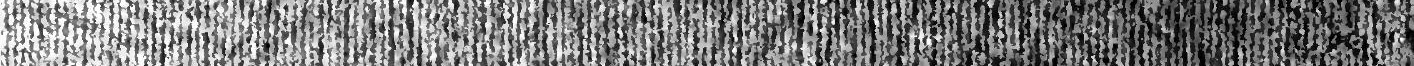

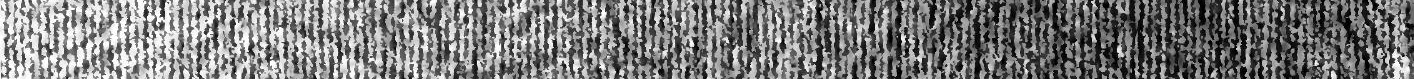
1. Han m.t.m

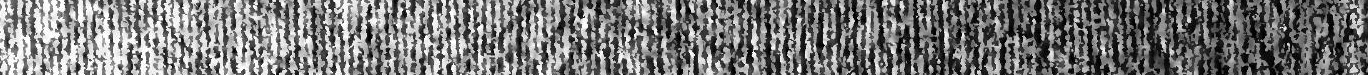
Hon mathom What

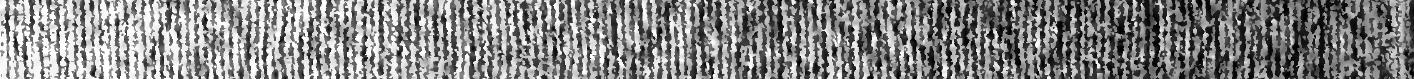

